UNIVERSIDADE DE SÃO PAULO

FACULDADE DE FILOSOFIA, LETRAS E CIÊNCIAS HUMANAS

DEPARTAMENTO DE ANTROPOLOGIA

PROGRAMA DE PÓS-GRADUAÇÃO EM ANTROPOLOGIA SOCIAL

\title{
SABORES E MEMÓRIAS: COZINHA ITALIANA E CONSTRUÇÃO IDENTITÁRIA EM SÃO PAULO
}

Janine Helfst Leicht Collaço

Tese apresentada ao Programa de Pós-Graduação em Antropologia Social da Faculdade de Filosofia, Letras e Ciências Humanas da Universidade de São Paulo, para obtenção do título de Doutora em Antropologia Social

Orientador: Prof. Dr. Vagner Gonçalves da Silva

São Paulo

2009 
Dedico esta tese à minha família e, em especial, meu marido e minhas filhas que tiveram ao longo desses anos infinita paciência. 


\section{AGRADECIMENTOS}

Retribuir, dar e receber são princípios que nos seguem pela vida, como já bem disse Mauss. Por isso, é hora de agradecer a todos que me apoiaram ao longo desses anos para atingir o fim de mais esta etapa. Confesso se para alguns é um momento de alegria, para mim representa um misto de apreensão e alívio. Primeiro porque gostaria de ter todos os que me apoiaram neste caminho bem perto e poder dizer, frente a frente, obrigado. Apreensão porque nem todos ouviram esse obrigado, e acalento a esperança de que algum dia estas palavras cheguem como um olhar ou um gesto, uma imagem que possa ser tão real quanto imaginada. Alívio porque é sempre um regozijo ver um trabalho finalizado.

Agradeço aos inúmeros familiares e amigos que estiveram comigo todo este tempo. Ao meu orientador, Vagner Gonçalves da Silva, pelas suas contribuições e parceria ao longo destes anos que, apesar da distância entre cidades imposta pelos caminhos que a vida nos coloca, nunca foi um obstáculo para nosso trabalho. Deixou-me livre para refletir sobre diversos temas, mas sabia o momento de intervir, pontuando suas observações com firmeza, as quais eu tinha plena liberdade de concordar ou não, mas com clara intenção de me fazer atingir o meu melhor. Sem dúvida, é um orientador generoso. Não posso deixar de agradecer ao meu marido, Alcyr, pelo apoio e todos esses anos de carinho, sempre me incentivando e com especial interesse neste trabalho, pois é um grande apreciador da boa comida. Veremos se a receita resultou boa. Às minhas filhas, Maria Eugênia e Maria Eleonora, preocupadas com minhas "escrituras" e, apesar de pequenas, souberam entender quando a mamãe estava "ocupada no computador". E logicamente aos anjos da guarda da minha casa, Nádia, Fátima e Luciano por permitirem que eu tivesse mais algum tempo para dedicar às linhas.

Aos meus pais, Janet e Hans, por acreditarem em mim e mesmo sem saber muito bem o que é este trabalho, nunca duvidaram da minha capacidade e desejo de terminá-lo como eu imaginara. E agradeço pela forma como me fizeram ver que as piores dificuldades podem ser enfrentadas com serenidade, especialmente nestes últimos anos pelos quais vicissitudes têm sido a tônica dos nossos cotidianos. Martin e Fernanda, irmão e cunhada por me deixarem tranquila ao saber que estão sempre por perto quando é preciso, meus sobrinhos Maria Eduarda e João Arthur, doces e divertidos. Ao meu irmão Paul, por ser quem é e ter sido um grande apoio nos dias finais da entrega. Aos meus sogros, Alcyr e Vera, sempre amorosos e interessados. Às minhas cunhadas Tais e Sônia, ao cunhado de meu marido Ricardo, sempre alegres e os meus sobrinhos já incorporados, Juliana, Rodrigo, Caio e Fernanda (madrinha) amorosos e divertidos, além é claro das novas integrantes, ambas Sofias, que chegaram para nos alegrar.

Gostaria de agradecer também aos meus interlocutores, apesar de ocupados sempre tiveram tempo para esclarecer, sentar e conversar. Sem eles certamente não teria sido possível este trabalho. 
Aos funcionários do Memorial do Imigrante que sempre foram solícitos e acredito, gostaram tanto de meu trabalho, que pensaram ser melhor me deixar trancada na sala de pesquisa, onde talvez eu pudesse aproveitar um pouco mais do material que me disponibilizaram. Esquecimento que não deixa de ser instigante para um trabalho que se propõe a falar de memória em um lugar que a cultua. E desculpem pela janela quebrada, foi um ataque de desespero ao imaginar uma noite no museu.

Agradeço ao Departamento porme fazervero valor do apoio institucional, bem como seus professores que acompanharam meu trabalho e aos colegas do Núcleo de Antropologia Urbana - NAU que com suas discussões, despertaram força para explorar este tema. Nesse sentido, gostaria de agradecer minha banca de qualificação, José Guilherme C. Magnani e Ellen Fensterseifer Woortmann, pelas preciosas contribuições que me permitiram repensar passos deste trajeto. Inclusive, devo dizer que a Professora Ellen esteve muito presente ao meu lado nos anos de adaptação em Brasília e enquanto estive no Centro de Excelência em Turismo da Universidade de Brasília, CET/UnB foi uma pessoa que sempre me incentivou. À Esther Katz, divertida e alegre, incentivou-me em meu trabalho e organizou com maestria um belíssimo encontro na ABA de 2008. E por acreditar na força de nosso Grupo de Pesquisa Alimentação e Cultura, ainda incipiente, mas certamente com futuro brilhante.

Agradeço à Universidade de Brasília, em especial ao Centro de Excelência em Turismo, $\mathrm{CET} / \mathrm{UnB}$, onde trabalhei dois anos como professora visitante. À Carla Tenser, com quem tive contato estreito, devo agradecer pela compreensão e pelas boas risadas. À Núbia David Macedo, à Profa. Dra. Wilma Araújo e a todos os colegas do CET/UnB com os quais partilhei um tempo de minha trajetória e o apoio inestimável em horas especiais. Ao Prof. Dr. Ricardo Maranhão, apesar do pouco contato recente, os anos de trabalho na Universidade Anhembi-Morumbi foram enriquecedores. Às minhas companheiras de área e hoje amigas de coração, Profa. Dra. Mônica Chaves Abdala e Profa. Dra. Renata Menasche, agradeço o ombro em horas difíceis: graças a vocês consegui respirar e continuar; suas palavras sempre foram bem-vindas.

Aos meus alunos por mostrar-me como é importante ampliar os horizontes, discutindo novas abordagens que às vezes ignoramos, não de maneira consciente, mas apenas por estarmos demasiadamente envolvidos em nosso mundo e questões.

Às minhas amigas saudosas e amadas: Francirosy Campos Barbosa Ferreira que com sua força e objetividade esteve sempre ao meu lado e, sobretudo, no fim deste trabalho mostrou ainda mais sua amizade ao me colocar acima de seus problemas e ser generosa com esta criatura à beira de um ataque de nervos. Adorei sua leitura! À Claude Papavero pelas conversas sobre um tema que escolhemos e compartilhamos (e adoramos) explorar, a alimentação. E minha querida Caroline Cotta de Mello Freitas sempre companheira e para quem não pude dar toda minha assistência em momentos de grandes turbulências, mas uma amiga sempre presente no pensamento e no coração.

Enfim, agradeço a todos que estiveram envolvidos de alguma maneira neste trabalho e que colaboraram para este resultado. 


\section{RESUMO}

Esta tese apresenta uma discussão do papel da cozinha na formação de identidades. Desenvolvendo uma discussão a partir dos conceitos da antropologia da alimentação, especialmente considerando a cozinha como um modelo capaz de expor relações sociais e um processo em constante contato com o diferente, ela se define com um importante instrumento para construir identidades. A etnografia foi conduzida em restaurantes que ofereciam uma cozinha particularmente emblemática para a cidade de São Paulo, a italiana, tomando estabelecimentos que tivessem mais de cinquenta anos de existência na cidade.

Ante isso, ao utilizar esse critério para definir o recorte, era preciso buscar refinar essa seleção, especialmente ao lidar com memórias de proprietários desses estabelecimentos. Dessa forma, foram selecionados três períodos considerados centrais na trajetória dessa cozinha e intimamente associados ao processo de imigração: o início do processo no começo do século XX; os anos 1950 e 1960 que trouxeram novos imigrantes italianos do pós-guerra para uma cidade tomada pela modernidade e, finalmente, os anos de globalização, especialmente após a nomeação da cidade como Capital Mundial da Gastronomia, ou simplesmente capital gastronômica, em 1997. Essa metodologia nos permitiu abordar questões em torno das articulações entre etnicidade, identidade e nacionalidade.

A conclusão após estes anos de pesquisa foi que a italianidade é uma percepção flexível, embora a imigração e, em especial a italiana, tenha sido tomada como um dos elementos de maior expressão para definir São Paulo como uma metrópole cosmopolita. A comida italiana acompanhou os ritmos urbanos e a cadência de imigrantes italianos que tentavam assentar identidades ainda frágeis em diferentes contextos.

Palavras-Chave: antropologia da alimentação, cozinha italiana, imigração italiana, identidade, cidade 


\begin{abstract}
This thesis presents a discussion about the role of the cooking in the identity construction. The starting point was the concepts of Anthropology of food and with a special focus on the idea of cuisine like a system and process where the practical operation exposes social relationships and, in fact of this, work on identities. The ethnography was made in restaurants of a particular cuisine at São Paulo, which is very emblematic, Italian cuisine.

For this, the way adopted was enter in the process of the cuisine by the memories of the owners of these restaurants, which are selected by a special criteria, have more than fifty years of existence and divide this trajectory in three main parts: the first period of immigration around the first decade of $20^{\text {th }}$ century, the 1950 and 1960's for enter at the new urban rhythms and the globalization years, specially at 1990's when the city was called "Mundial Capital of Gastronomy". Adopting this, we could discuss the arrangements between ethnicity, identity and nationality.

The final considerations shows that the italianity becomes part of the urban imaginary and one of $t$ he most particularities of this cosmopolitan city. The Italian cuisine shows these articulations and how follows the new urban rhythms adapting fragile identities in different contexts.
\end{abstract}

Key Words: anthropology of food, Italian cuisine, Italian immigration, identity, city 
SUMÁRIO

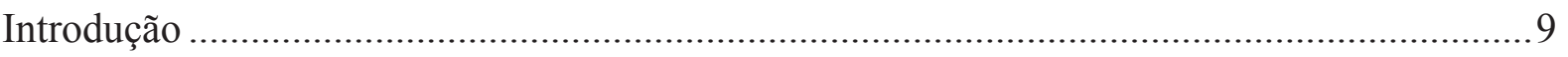

Capítulo 1: Novas Vozes na Cidade: Cozinha italiana e espaços étnicos - a Cantina ............. 19

1. Imigrantes na capital paulista: cidade estranha, estranha cidade ...................................... 19

2. A cozinha italiana na capital paulista: um modelo local em construção .............................. 43

3. A Cantina: modelo de sociabilidade e lugar de comida étnica e familiar ............................61

Capítulo 2: Imigrantes italianos e novos italianos: a disputa pela legitimidade na cozinha ....77

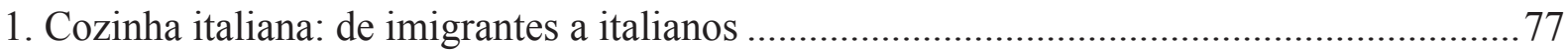

2. Restaurantes: disjunções na cozinha italiana .................................................................. 98

3. Restaurantes e famílias: a variedade da experiência étnica ...............................................114

4. A cozinha italiana, mudanças e formação de identidades ..................................................129

Capítulo 3: Cozinha italiana na Capital Mundial da Gastronomia: embates entre o tradicional e

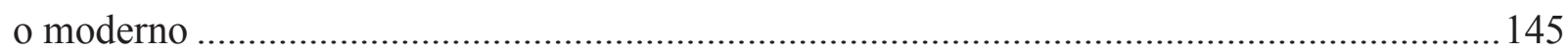

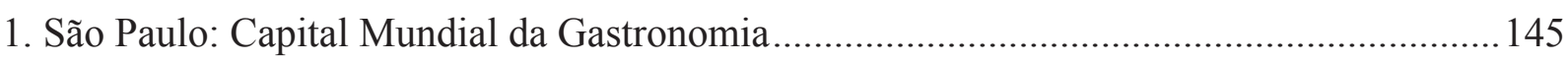

2. Gastronomia, Consumo e cidade - o tradicional e o novo ............................................... 168

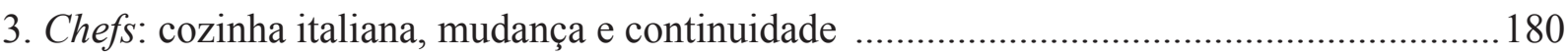

4. Comida italiana ao alcance de todos: pizzas e restaurantes de comida rápida ....................197

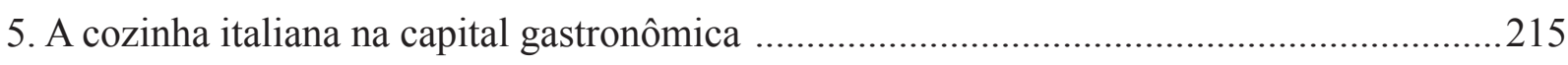

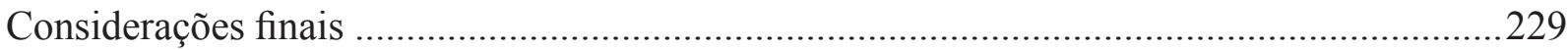

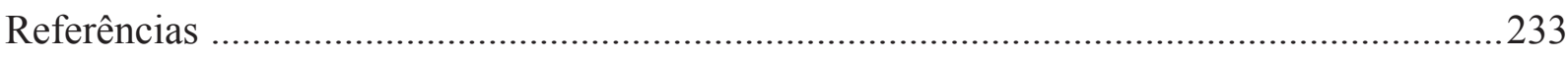

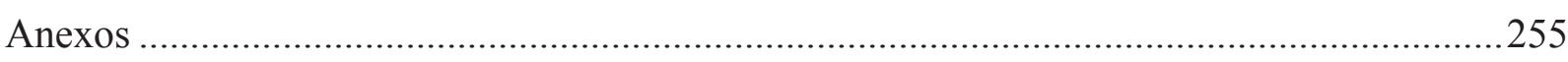

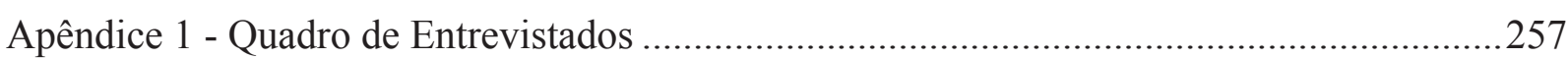

Apêndice 2 - Divisão geopolítica da Itália e suas regiões ....................................................263

Apêndice 3 - Mapa da cidade de São Paulo e seus bairros ....................................................269

Apêndice 4 - Mapa de Distribuição da produção de massas na Itália .....................................227

Apêndice 5 - Roteiro básico - Entrevistas Doutorado .........................................................279 



\section{INTRODUÇÃO}

Este é um trabalho que pretende entender o papel da cozinha na formação de identidades. De um ponto de vista mais amplo, o ponto de partida são conceitos desenvolvidos pela antropologia da alimentação e pelos quais a pesquisa tenta entender como se articulam cozinha, concebida como um modelo capaz de expor relações sociais, e construção de identidades. Para tanto, o caminho percorrido será o uso das memórias de proprietários de restaurantes de cozinha italiana para mergulhar em uma trajetória que hoje representa uma das principais imagens da cidade de São Paulo, denominada também de Capital Mundial da Gastronomia, ou simplesmente capital gastronômica.

A decisão de enveredar por este caminho foi gerada anos antes em função de meu trabalho anterior, Collaço (2003). Em vários momentos daquele trabalho surgiram manifestações espontâneas com relação à comida italiana na cidade. Era sempre uma alternativa apreciada como viável para realizar refeições fora de casa que, no entanto, oferecia distintas opções, não só em termos de comida, mas também com relação a outro ícone local, a pizza.

Ante isso, não bastava justificar essa preferência porque São Paulo recebeu o maior fluxo de italianos do Brasil e acomoda mais de 6 milhões de descendentes. Entre essas gerações e a realidade atual da cidade existia um vácuo de quase um século, portanto, essa justificativa não seria plausível, mesmo porque se o fosse deveríamos ter então cozinha portuguesa em cada canto da cidade, bem como comidas associadas aos negros. Obviamente que essa não é a realidade.

Não houve intenção também de explorar a formação de um gosto pela comida italiana, embora em algumas passagens do trabalho fiquem implícitas como ocorreram algumas mudanças. $\mathrm{Na}$ verdade, a cozinha italiana como uma classificação mais geral abriga no seu interior inúmeras incongruências que serão analisadas, embora não esgotadas, na trajetória dos restaurantes de cozinha italiana presentes na cidade há mais de cinquenta anos, nosso recorte empírico.

Os restaurantes ganharam evidência há pouco mais de dois séculos, embora existissem desde muito tempo, mas com o advento de novas sociabilidades foram espaços privilegiados na cena social contemporânea. Do lado da cozinha também revelaram disputas e conflitos que se estendem para além de seus limites, dialogando não só com a sociedade local, mas com elementos de fora, especialmente o imaginário com relação à Itália.

A cozinha, então, representada nesses estabelecimentos estabelecerá diálogos não só com os comensais, mas também na forma como organiza seu abastecimento, o preparo da comida, quem a consome, como e quando; quem se encarrega de servir e limpar, mostrando que essas articulações terão implicações profundas na maneira de pensar a posição social do restaurante, seus donos e frequentadores. 
É verdade também que trabalhar com a memória desses proprietários não afasta a incorporação de representações recentes na percepção de sua trajetória, um processo de seleção e descarte que tenta evidenciar uma determinada posição e ressaltar uma identidade. Ante isso, a memória é sujeita a inconsistências que fazem dela um caminho tortuoso, especialmente se há a pretensão de realizar uma historiografia, que não foi o caso desta pesquisa.

Nesse sentido, o principal objetivo era tentar compreender como esse grupo de restaurantes de cozinha italiana e seus proprietários pensavam a trajetória de seu estabelecimento e de sua cozinha na cidade, formulando suas identidades a partir de distintas interações e interpretações. Para finalizar, avaliar o impacto dessa trajetória na construção da imagem de Capital Mundial da Gastronomia, título atribuído à cidade em 1997.

Vale lembrar que a comida italiana logo que chegou foi considerada com desconfiança e circulava apenas entre imigrantes italianos. A comida delimitava as fronteiras da exclusão e inclusão, acionadas segundo conveniências que variavam conforme ajustes conjunturais. Comidas que antes eram consideradas de pobres passam às mesas dos mais privilegiados, como foi o caso das pizzas do fim do século XIX, ou se tornam globais como no século XX. A cozinha assumiu distintos significados ao longo de sua trajetória na cidade, falando de imigração, italiano, comida, nacionalidade.

Dessa forma, falar de formação de identidades, ou reconhecimentos, é pleno de ambivalências e refletem o caráter contextual em que transcorrem, sobretudo em situações de imigração. Surgem soluções conjunturais possíveis que não ignoram dinâmicas locais de classificação, muitas vezes apropriadas pelos novos habitantes como suas, bem como localmente incorporam aspectos de fora como algo naturalmente local. A imigração, apesar da retórica oficial que tende a desenhá-la como um processo ameno, esteve longe disso e não se furtou a vários desencontros que se refletiram na forma como a comida italiana emergiu.

A comida não é identidade per se, ou expressão cultural de um povo, grupo ou território como é comum ouvir no discurso do senso comum. Ela é um material extremamente maleável que promove representações em distintos planos que se entrelaçam para dar consistência ao comer. Isso significa ter em mente que os produtos servidos foram selecionados, preparados e destinados para o consumo de alguém, em algum momento, junto de outras pessoas. A comida é relacional, assim como a identidade, de modo que o mesmo material pode-se prestar a distintas interpretações.

Nesse caso, o ponto de partida do trabalho era ter consciência que a cozinha italiana, antes de representar um país e abarcar um conjunto de receitas, era uma referência com mobilidade. Consumir essa comida fora de onde foi inicialmente gerada, viajar e ser reproduzida em outra situação teve um primeiro impacto entre os imigrantes que recém aportavam na São Paulo do começo do século XX. Mas, também para a cidade que estranhava esse paladar. 
Com o correr do tempo e a inserção de filhos e netos de imigrantes italianos na sociedade local, novos arranjos foram constituídos e a cozinha passaria por novas revisões até ser o tipo de comida mais predominante em restaurantes listados em guias e roteiros da capital paulista.

Para poder acompanhar uma preferência tão acentuada, a decisão então foi buscar meios de acessar essa cozinha, recaindo sobre os restaurantes. Essa decisão teve várias motivações. Primeiramente, porque é uma comida que circula fora dos limites domésticos, sendo mais acessível; segundo porque poderiam ser procurados estabelecimentos com mais tempo de existência que permitissem comparar os distintos usos dessa cozinha e os seus reconhecimentos; terceiro porque seria praticamente impossível focar nos comensais dessa cozinha e ao concentrar nos seus produtores, de alguma forma ou de outra se poderiam inferir articulações com os consumidores.

Nesse sentido, o próximo passo foi selecionar estabelecimentos os quais tivessem mais de cinquenta anos de existência na cidade, o que na verdade, ao invés de dificultar, facilitou o trabalho, já que não eram muitos que desfrutavam dessa particularidade. Entre os que foram escolhidos, alguns nasceram nos bairros associados à imigração italiana, como Brás e Bixiga; outros surgiram no centro, no auge dessa região. E nos anos globais se defrontaram com a especialização em bairros residenciais, shopping-centers e surgimento de novos pólos de concentração de lazer, especialmente na zona sul de São Paulo (Itaim Bibi, Vila Olímpia e adjacências).

Alguém pode questionar, mas cozinha italiana de restaurantes não é um consumo cotidiano para a maioria das pessoas, assim como os rituais tampouco o são e expressam valores e ideias da sociedade que os sustentam. Dessa forma, comer fora de casa também adquiriu novos sentidos com o passar dos anos, prática que acompanhou as mudanças nos restaurantes. Se para o comensal era uma saída eventual, tornou-se mais corriqueiro ante os arranjos do mundo contemporâneo. Por outro lado, para o dono do restaurante o sentido era outro, pois representava sua principal atividade e dali sairia seu sustento. Muitas vezes, a família se via envolvida no negócio, novas gerações eram incorporadas ao trabalho, enfrentavam dificuldades, se sentiam diminuídos ante os ritmos da cidade. O restaurante agrega vários planos: produção, consumo, cozinha local e global, cozinha tradicional e cozinha moderna, cliente assíduo e eventual.

A instabilidade que emerge quando se lida com comida e identidade por si traz algumas dificuldades para a organização dos dados. Assim, inicialmente foi pensado em trazer a análise disposta por modelos de restaurantes representativos em cada uma das três fases consideradas importantes para a trajetória da cozinha italiana na cidade de São Paulo: a chegada dos imigrantes no inicio do século XX e as primeiras décadas de sua adaptação; as décadas de 1950 e 1960 representando a consolidação da modernidade na cidade; e os anos de Capital Mundial da Gastronomia que coincidem com a globalização. 
Entretanto, ao longo do desenvolvimento do trabalho foi necessário mudar essa estratégia e pensar a construção dessa trajetória sob outro modelo. Nesse caso, a opção recaiu em um modelo que poderia, grosso modo, ser um conjunto de círculos sobrepostos, inclusive porque era a forma mais conveniente de seguir o próprio fluxo das narrativas. Desse modo, havia um evidente crescente de informações à medida que a memória se aproximava do tempo presente, até porque esse processo tinha para alguns interlocutores uma função clara, definir seu lugar. Nesse sentido, fazer um corte abrupto tomando como exemplo determinado estabelecimento e posicioná-lo em um lugar da trajetória seria uma boa estratégia desde que se fixasse exclusivamente a uma temporalidade em particular, o que não foi o caso.

Além disso, se localmente os modelos de fato estivessem associados a determinados espaços urbanos, eles dialogavam com o imaginário regional italiano, bem como temporalidades que se mesclavam à medida que os imigrantes abriam seu lugar na sociedade local. Nas memórias coletadas esse processo não é uma referência clara, mas evidente ao comparar os discursos e perceber as estratégias que hoje pretendem valorizar a imigração como um fato de grande importância para a cidade. E a comida parece que se vale da mesma estratégia.

$\mathrm{O}$ fato de o estabelecimento ser passado entre gerações criava justaposições expostas nas memórias e com um objetivo bastante claro, falar sobre o presente e de uma posição que permita reconhecimento, quer seja da cozinha, do restaurante, do proprietário. Desse modo, a cozinha praticada nos distintos períodos não ficava isolada da anterior, dialogavam muitas vezes até em um mesmo estabelecimento, convivendo com espaços e tempos que falavam sobre a experiência da imigração sob perspectivas particulares. Na verdade, eram diferentes italianidades expostas nos restaurantes que entre italianos se sabiam diferentes, mas nem sempre absorvidas como tal pela população local. Esta irá ganhar familiaridade com essa cozinha bem mais tarde, por volta dos anos 1950, para ser - nos anos em que a cidade se firma como Capital Mundial da Gastronomia - a principal cozinha presente em restaurantes da cidade.

Assim, a maneira mais cômoda de analisar os dados foi imaginar esse conjunto composto de círculos concêntricos em que novos restaurantes e sentidos dessa cozinha se adicionam ao modelo anterior, criando justaposições. Nessas, o modelo mais antigo não é descartado, mas assume uma nova relação e percepção em função dos restaurantes que surgem. Desse modo, a cozinha italiana que transitará publicamente emerge na cantina; a partir dos anos 1950, nas cantinas e nos novos restaurantes mais refinados de cozinha italiana; e, finalmente, nos anos de globalização, além desses restaurantes, são as pizzarias, restaurantes de comida rápida, bistrôs entre outros que traduzem a explosão de linguagens dessa cozinha.

A cozinha italiana oferecida nos distintos tipos de restaurantes evidenciou interações locais e internas, usos dos espaços urbanos, bem como refletia distintos ritmos que emergiam em São Paulo. Esse ponto nos conduz a outra questão que também será abordada ao longo deste 
trabalho, os encontros culturais como as margens que possibilitam o intercâmbio de ideias e práticas, constituindo novas percepções e apropriações.

É certo, como já apontou Mary Douglas, que a comida é um dos marcadores de fronteiras étnicas mais potentes, mas está longe de ser estável. Comida fala sobre identidade o tempo todo e se apropria de ideias que circulam em torno de emblemas nacionais e regionais, entre famílias, posição social, idade e manipulada a partir de relações sociais. Portanto, sob a perspectiva da cozinha a solução mais conveniente foi dispor os dados dessa forma. Não há um corte abrupto, um ritual específico realizado em um dia especial. O restaurante abre suas portas diariamente, o que muda é a percepção do comensal em função do lugar que a refeição ocupa (festiva, dominical, almoço rápido, familiar, comemorativa etc.) e a forma como seus proprietários lidam com seu estabelecimento, sua cozinha em diferentes pontos da trajetória.

A ambiguidade persistiu em cada momento analisado, as estratégias adotadas para se valer em uma nova sociedade dependiam das condições vividas e não tinham uma definição clara, mesmo porque logo ao chegar esses imigrantes nem mesmo se consideravam italianos. Nesse caso, no princípio a cozinha teve como principal papel a indução de um reconhecimento étnico, em parte pelo diálogo que se estabelecia com a sociedade local.

Nas décadas seguintes, o fluxo de imigrantes diminuiu, porém não cessou totalmente, fato que só ocorreu nos anos 1960. Ante isso, se nas narrativas parece existir uma continuidade representada pelos descendentes de imigrantes, estes se viram confrontados com os novos imigrantes que chegavam após a 2 a Guerra, criando um ambiente de animosidade entre as partes. Essa diferença foi amenizada tempos depois e já sob uma retórica em que a imigração foi um grande trunfo para a cidade.

A densidade de informações é, nesse sentido, muito mais acentuada nos tempos atuais, escasseando à medida que a memória se aprofunda nas raízes da cozinha italiana na capital paulista. Nesse sentido, chegou a ser decepcionante, em algumas entrevistas, a dificuldade em estabelecer conexões com o passado que já não estivessem quase totalmente embebidas de representações atuais, especialmente no tocante à experiência imigratória.

As conversas realizadas requisitaram uma atenção especial nesse ponto e tentando perceber onde estava de fato uma experiência e onde era a reprodução de uma narrativa já montada que, em geral, se destinava à audiência popular incentivada pela retórica oficial e pelos próprios meios de comunicação. Com relação a esse aspecto, estigmas relativos aos primeiros tempos foram omitidos, bem como as disputas entre italianos da velha guarda e novos fluxos que vieram após a 2 ${ }^{a}$ Guerra são apenas detalhes de uma trajetória que se pretende quase uma saga.

Cuidado também foi necessário com relação a não pressupor uma comunidade como é comum ouvir no senso comum e na circulação de imagens desses italianos. Estas são em parte fomentadas pelas festas e pela retórica oficial da cidade que tende a definir imigrantes 
italianos - bem como "árabes", "japoneses" - com classificações étnicas que não dizem muito em seus países, mas na cidade explicam muito. Na verdade, ao chegarem, todos esses novos habitantes não eram mais que excluídos; entretanto, conseguiram ser incorporados à narrativa oficial.

Para São Paulo, sua diferença está justamente no fenômeno de imigração. O progresso veio pelas mãos dos imigrantes, eles trouxeram civilização, apesar de que nem sempre a realidade tenha correspondido a essa percepção. Consumir comida italiana talvez traduza algo dessa particularidade, ela é naturalmente pertencente à cidade, mas é também civilizadora. Tanto é assim, que pouco se menciona a participação dos nordestinos aportados à cidade e cujo trabalho foi também fundamental na construção da metrópole, mas não eram europeus e brancos, percepção estendida a outros grupos, como os japoneses e sírios ${ }^{1}$.

Por outro lado, minha experiência precisa ser relativizada, pois via os italianos como algo comum na cidade e particularmente importantes para criar a metrópole. Tirar o caráter natural dessa cozinha foi um exercício íntimo, ao mesmo tempo instigante já que precisava revisar uma série de concepções com as quais convivi ao longo de minha vida, ouvia regularmente na escola, na rua, na televisão, mais tarde na faculdade e no trabalho. Macarrão e pizza eram "coisas de paulista" e dos italianos.

Nesses movimentos sutis é preciso perceber as inversões, as inflexões que nem sempre se expõe de modo claro nas memórias, exigindo um trabalho minucioso, artesanal e às vezes frustrante, sempre incompleto. É como Bosi (1996) notou: a memória não é um contínuo, é uma espiral que ressuscita elementos para confortar, para apagar os que incomodam e dar esperança. E reforçou a decisão de construir a análise dos dados seguindo esse fluxo, menos amparado em modelos que definissem uma identidade específica e mais um como um processo de sobreposições que irão falar sobre diferentes identidades.

Esses aspectos perpassam continuadamente pelas narrativas, a verdade é que o mundo social se amarra às memórias, como bem argumentou Halbwachs (1997). A evocação de imagens do passado possui uma função social, ao desenhar um quadro pretérito no presente com detalhes esmaecidos pelo tempo, essa tentativa de reconstruir acontecimentos acaba, mesmo involuntariamente, gerando uma mistura de conteúdos. E um pouco mais de atenção, mostra que as formas de lembrar expressam as bases culturais compartilhadas por determinado grupo ou comunidade, aspecto que Paul Connerton (1989) discutiu².

A comida como um material flexível e de certa forma reconhecido entre distintos grupos proporcionou aberturas para pensar como é se movimentar muitas vezes em espaços que não estão claros. Etnia e exclusão, distinção e classe, geração, classe e gênero, são todas identidades

1 Para essa discussão, consultar Lesser (2001).

2 Esse processo é próximo ao sugerido por Anderson (1991) quando discorre sobre a constituição dos estados nação. 
presentes na comida. Algumas predominaram em certos momentos, mas seguem presentes nas memórias e moldam representações em torno da cozinha e do comer. Os restaurantes e sua comida não ignoram essas interlocuções.

Os restaurantes selecionados e os proprietários entrevistados mostraram a passagem de diversos sentidos pela cozinha italiana e seus diálogos. Contaram sobre os estabelecimentos nascidos no seio de bairros étnicos, restaurantes nascidos na pujança do centro de São Paulo e a variedade de restaurantes que nascem nos bairros da cidade, especialmente de camadas médias ao lado das pizzarias e entregas ${ }^{3}$.

Para tanto, tentei encontrar representantes dos distintos modelos que pudessem me descortinar as negociações que pontuaram a trajetória da cozinha italiana, imigrantes italianos e cidade. Interlocutores que pudessem abrir suas memórias e explorar seus sentidos, não apenas a história do restaurante, como muitos pensaram estar fazendo, mas suas percepções a respeito de cada momento e a forma como seus estabelecimentos se posicionaram para falar de distintos reconhecimentos. Contei também com depoimentos disponíveis no Memorial do Imigrante, procurando resgatar conversas de interlocutores que estiveram relacionados a restaurantes e já tivessem falecido ou impedidos de falar ${ }^{4}$.

As entrevistas foram conduzidas tendo em mente esses vários aspectos. A definição do recorte até que não ofereceu muita dificuldade, considerando que não existiam muitos restaurantes com as características desejadas. Foram feitas várias visitas nos estabelecimentos selecionados, nem sempre realizando entrevistas nessas ocasiões, pois também havia o intuito de observar outras dinâmicas. Alguns entrevistados foram mais receptivos, outros nem tanto, mas essas atitudes com relação ao trabalho apontavam elementos para serem desenvolvidos. Ao incomodar alguns interlocutores, sentia que ali existia uma questão a ser explorada.

Alguns obstáculos surgiram como a ausência de cardápios antigos preservados pelo restaurante, a dificuldade de conseguir autorizações para o uso de fotos, não conseguir contatar algumas das pessoas que pretendida. Não cogitei falar com os comensais, já que neste caso, precisaria realizar outro trabalho, talvez em outro momento e circunstâncias. Jornais e revistas, especialmente dos anos 1980 em diante foram uma boa fonte de informações em torno das representações que envolviam a noção de Capital Mundial da Gastronomia, embora nenhuma menção anterior tenha sido encontrada. Nesse caso, quase nada foi encontrado sobre restaurantes

3 Vide o quadro no anexo, apêndice 1, em que consta o nome dos estabelecimentos, o nome do proprietário ou entrevistado, bem como os depoimentos utilizados do Memorial do Imigrante e as datas em que foram realizadas as coletas de dados. Doravante apenas irei comentar o nome do entrevistado e se necessário algum detalhe considerado importante para o desenvolvimento do texto.

4 Esse projeto foi conduzido por Sônia Maria de Freitas e inclusive seu doutorado, defendido em 2001, me proporcionou informações valiosas. Entre os que já haviam falecido estavam Alfredo DiCunto (confeitaria DiCunto) e Domenico Laurenti (Padaria Basilicata), além de Piero Grandi Luisi , embora não falecido, ainda lúcido quando concedeu o seu depoimento. 
antes dos anos 1960, uma menção aqui e outra acolá. Nesse sentido, os memorialistas foram um material consultado com frequência para avaliar como eram os encontros urbanos de começo de século, até porque muitas vezes as memórias não alcançavam esse período, dificultando recriar passos dessa cozinha em um ambiente novo.

Dessa maneira, o primeiro capítulo, Novas Vozes na Cidade: Cozinha italiana e espaços étnicos - a Cantina, inicia-se com uma descrição de quem eram esses italianos e como chegaram à cidade, tentando mostrar o estranhamento entre imigrantes e sociedade local. Nesse capítulo é revisto o conceito de cozinha italiana, bem como os principais pratos italianos que rapidamente começaram a circular pela cidade, uma forma de criar meios de proximidade e estimular um sistema de intercâmbio informal. Foi o momento de convívio em bairros étnicos e do surgimento das cantinas, um modelo de restaurante, por assim dizer, marcado pela presença feminina na cozinha.

No capítulo seguinte, Imigrantes italianos e novos italianos: a disputa pela legitimidade na cozinha levou-se em consideração o embate entre a velha guarda composta dos italianos que vieram na primeira leva e os italianos que vieram após a $2^{a}$ Guerra mundial. Nesse sentido, é preciso considerar o crescente número de descendentes, nem todos interessados na continuidade dos saberes de seus pais, inclusive na cozinha, afetados também por políticas quase opostas geradas pela intervenção getulista e o governo fascista italiano, sobretudo no entre guerras. Disputas internas entre italianos se fizeram visíveis e se estenderam às cozinhas dos restaurantes, não só oferecendo diferentes sociabilidades, como também correspondendo a distintas formas de expressar suas italianidades, como bem observou Pereira (2003), reforçando os caminhos (ou descaminhos) de identidades de imigrantes italianos.

No último capítulo, Cozinha italiana na capital gastronômica: embates entre o tradicional e o moderno, é a diluição de um reconhecimento como italiano, mas ainda presente na cidade como influência primordial para a construção do progresso da cidade. É o italiano com força civilizadora, embora pouco reconhecida pela Capital Mundial da Gastronomia, um "golpe de marketing". Nesse sentido, aborda-se a questão do tradicional e do novo, da continuidade e da mudança, bem como a popularização da pizza que, mais descolada do contexto da cozinha italiana, criou uma trajetória própria na cidade. E novos reconhecimentos serão expostos face a face para definir pertencimentos que transitam entre Brasil e Itália.

As dificuldades de lidar com a alimentação não são poucas, como Goody (1982) já discutiu sobre as distintas abordagens que proporciona. Ela nos oferece uma multiplicidade de vozes que nem sempre são coerentes entre si, especialmente quando se coloca o desafio de desconstruir a ideia que tende a desenhar os italianos com um grupo coeso. Se houve laços étnicos em algum momento de sua trajetória que permitiu estreitar relações, foram sendo diluídos à medida que procuravam sair de uma posição subalterna. 
A comida expôs todos essas contradições, o regionalismo, a evocação do território como cultura, a temporalidade em várias versões, ressaltando que a alimentação ainda é um objeto que requer um manejo em distintos planos. Esse é o desafio que a antropologia da alimentação temse colocado e por isso tem privilegiado uma perspectiva processual, sem a qual, se perderiam elementos de peso.

Mary Douglas (1975) não ignorou o peso desse aspecto, apesar de sua fidelidade à análise estrutural. Ela entendeu que comida como um traço diacrítico parece uma perspectiva distanciada dos arranjos que marcam a sobrevivência e não se apoiam somente nas refeições rituais, pois o consumo alimentar adquire sentido pelas posições que uma refeição ocupa em um eixo de eventos alimentares. Existe, inclusive, uma hierarquia, portanto, de refeições, mas o restaurante não atende exclusivamente um tipo de consumo, pois dependerão das articulações em torno de ideias sobre religião, classe, gênero, geração. E apesar de que autora não deixou clara esta argumentação, ela é deixada subjacente ao longo de seu texto. Certos grupos adotam cozinhas como formas de permitir dar contornos a uma imagem, mas não são conjuntos fechados e em suas margens emergem as possibilidades de mudanças. A cozinha italiana demonstrou que essa é uma possibilidade concreta.

A comida fala de relações e as distintas situações pelas quais passaram os imigrantes italianos passaram estão de alguma forma presentes em sua cozinha, mesmo que muitas vezes os interlocutores não tenham plena consciência desse processo. O restaurante corresponde aos valores que cercam determinada cozinha, especialmente quando possuiu uma trajetória que a distingue de outras cozinhas presentes na cidade. Cabe à pesquisa tentar separar esses distintos planos e compreender os elementos relevantes dessas interações. 

Capítulo 1: Novas Vozes na Cidade: Cozinha italiana e espaços étnicos - a Cantina

\section{Imigrantes na capital paulista: cidade estranha, estranha cidade}

É sabido que as condições que permitiram a vinda de imigrantes para o Brasil é um encontro entre fatores de expulsão e fatores de atração, segundo Alvim (1986) ${ }^{5}$, um movimento descontínuo e movido por interesses que desencadearam a procura por uma mão de obra diferenciada. Em um primeiro momento, se dá a articulação política do Oeste, isto é, fazendeiros de café dessa região do estado de São Paulo, sem uma política definida e buscando alternativas à mão de obra escrava. Em seguida, (1885-1902) essa facção se consolida e define uma política de imigração, favorecendo especialmente o italiano. Finalmente, é consolidada a política imigratória promovida por São Paulo (1902-1920), datas importantes no sentido de mostrar que nas distintas fases se observam composições familiares diferentes. Inclusive, até 1902 os italianos que chegavam eram predominantemente do Vêneto e logo após, maioria da região sul.

Falar de vênetos, provenientes da região homônima, ao norte da Itália ${ }^{6}$, é lembrar que boa parte foi para o sul do Brasil e para o interior de São Paulo, falar de italianos meridionais é considerar as regiões da Calábria, Campânia e Basilicata, boa parte permanecendo na cidade de São Paulo, grupos com particularidades bastante evidentes. Entre 1870 e 1920 chegou cerca de um milhão de italianos, quase $40 \%$ da soma total de imigrantes, em um total de 2,5 milhões.

Do total de italianos, 1,4 milhões, 70\% permaneceram em São Paulo. Os meridionais, muitos braccianti (trabalhadores braçais) e cujo único bem eram seus próprios corpos, chegavam quase sem nenhuma habilidade específica a não ser usar seu corpo como instrumento de trabalho, segundo observou Alvim (2000). É verdade que imigrantes já chegavam ao Brasil antes da virada do século, mas muitos italianos, sobretudo da região do Vêneto preferiram o campo, formulando então o que seria, segundo Pereira (2003), a base para diferenciar distintas italianidades, no plano sociocultural distinguindo-se entre erudita e popular; no plano da fixação na terra entre imigrante (urbano) e colono (rural) ${ }^{7}$.

Com as transformações nas relações econômicas e expansão do capitalismo, a Itália foi transformada em fornecedora de mão de obra, uma vez que seu desenvolvimento industrial foi lento e sem condições de absorver o contingente populacional das regiões rurais, o que revela também italianos em distintas condições. No entanto, nem todos os italianos que saíram da Itália

\footnotetext{
$5 \quad$ Consultar também Trento (1988).

6 Consultar Mapa em anexo, apêndice 2, onde estão organizadas as regiões e divisão geopolítica italiana.

$7 \quad$ Para uma interessante análise da obra de Pereira, consultar Kosminsky (2007) que discorreu sobre a ausência de um olhar voltado às mulheres que poderia ter fornecido outras interpretações em torno do material etnográfico, especialmente em torno das relações familiares.
} 
apresentavam condições parecidas. Alguns pequenos e médios proprietários de terras enviaram membros da família para trabalhar como operários ou camponeses em outros países, em geral, na própria Europa. A emigração definitiva se deu nas regiões onde as relações com a terra mantinham laços ainda presos a resquícios feudais e qualquer mudança estrutural era praticamente vedada.

Os italianos do Vêneto tinham características particulares, em geral eram pequenos proprietários de terras na Itália e vinham interessados em amealhar terras no Brasil. A maioria se concentrou no sul do Brasil, outros foram para o interior de São Paulo e alguns para o Espírito Santo. A maioria, a partir de 1902, que se instalou em São Paulo, eram braccianti ou proletários rurais, italianos sem terra e em busca de alguma atividade fixa.

Estes possuíam algumas diferenças com relação aos vênetos, inicialmente sua condição era mais desfavorável, porém o núcleo familiar era menor que seus antecessores e não vinham de uma única unidade, mas sim de várias: Calábria, Campânia, Basilicata e Puglia. A preferência de permanecer na cidade estaria associada às experiências anteriores em que a terra se tornou um cativeiro insuportável e os orientou no sentido de preferir o meio urbano.

Brutalizados por uma desgastante situação de miséria, muitos italianos optaram por abandonar suas terras em busca de novas chances de vida. A pobreza assoladora da zona rural do fim do século XIX e início do século XX, aliada a uma política de recepção de imigrantes em países como Estados Unidos, Argentina e Brasil foram condições suficientes para movimentar milhares de pessoas em busca de uma vida melhor fora da Itália.

A conspiração de fatores de expulsão e a abertura para receber novos habitantes - especialmente no Brasil recentemente abolicionista - forjaram uma situação extremamente fértil para que o Estado de São Paulo e sua capital absorvessem um grande fluxo de imigrantes que, se acreditava, ficaria restrito às atividades do campo, especialmente alocados na produção de café. Entre morrer de miséria e fome em seu país, milhares de europeus acreditaram no sonho de fazer a América ${ }^{8}$. Diante desse quadro, na verdade as condições que iriam encontrar na nova terra não eram exatamente claras, mas valiam o risco diante da vida miserável do presente e que os esperava no futuro.

A promessa de melhora de vida pintava a imigração como um lance de sorte na vida das famílias, criando diferentes ideias nem sempre condizentes com a realidade encontrada. Nesse sentido, a diversidade de origens e experiências que marcavam esses italianos nos leva a revisar os próprios significados de italianidade, pois uma experiência de grande porte como a imigração não desenvolve a mesma percepção em função das articulações com a família, trabalho, dificuldades com a língua ${ }^{9}$.

Na verdade, o processo de imigração, como observou Baily (1999), não se encerrou com a adaptação dos descendentes e de fato, a comunicação com a Itália de alguma forma permaneceu

$8 \quad$ Fausto (2000) e também Schneider (1996).

9 Para uma interessante análise das percepções em torno da experiência imigratória, consultar Di Leonardo (1984). 
vigente; para tanto, basta se deparar com as enormes filas de netos e bisnetos de italianos na porta dos consulados, procurando comprovar sua origem e conseguir um passaporte europeu. Para muitos jovens, essa foi uma saída para encontrar melhores condições de vida, sobretudo em países que fazem parte da comunidade europeia. Alguns permanecem algum tempo e retornam, fazendo dessa experiência seu diferencial de vida e profissional ${ }^{10}$.

De qualquer modo, grandes processos de imigração, como foi o caso dos emigrados dos países europeus do começo do século XX, respondem a um fenômeno estrutural em que fatores de expulsão e fatores de absorção agem em conjunto para formalizar o fenômeno ${ }^{11}$. No entanto, se essas condições orientam a decisão de emigrar, delineando as possibilidades de novos lugares e trabalho, é preciso tomar decisões de nível cotidiano que permitam conduzir a vida de alguma forma no mínimo, suportável. Emergem algumas estratégias coletivas que tentam minimizar o impacto da experiência e facilitar o ajuste à nova sociedade.

Nesse sentido, falar em comunidade italiana no começo do século XX seria ir além dos fatos e uma visão atual do que era ser italiano e da italianidade ${ }^{12}$. Na verdade, a construção de limites entre os distintos grupos de italianos foi lenta e contou com um reforço quando a Itália consolidou seu processo de estado nacional, ainda não firme por volta dos anos 1930. Até então, falar em Itália era ter como referência um território ocupado por distintos grupos com culturas diferenciadas.

Obviamente que essas divergências não poderiam constituir uma visão homogênea da cozinha italiana, fenômeno que ocorreria mais tarde, embora ainda fincado sobre as disparidades regionais. Alguns interlocutores comentaram sobre esse fenômeno, pois claramente viveram essas diferenças antes de se transferir para o Brasil, ou assim ouviram de seus pais. Unificar nem foi o caso na Itália, mas de certo modo foi o que transcorreu na capital paulista, como lembrou Ana Maria Carrer,

\begin{abstract}
Vim descobrir comida italiana no Brasil, encontrei coisas que eu não conhecia [...], por exemplo, lasanha, eu não sabia o que era lasanha [...]. Na Itália a cultura culinária é muito regional e alguns pratos do sul eu nunca tinha visto. A cozinha que eu conhecia era do Vêneto, até porque minha mãe era de lá. A Pastiera di Grano nunca tinha comido [...] Em 1940 a unidade italiana estava começando [...] quando cheguei descobri facetas da Itália que eu não conhecia [...]fiquei conhecendo comida italiana aqui no Brasil.
\end{abstract}

Ana Maria morava em Roma e era filha de um advogado conceituado em Roma, veio nas últimas levas de imigrantes, mas a família de seu marido já havia estado no Brasil e retornado para casar os filhos. Trajetória semelhante teve a família de Alfredo DiCunto que atualmente

$10 \quad$ Não acessei nenhum trabalho a esse respeito, mas há uma vasta literatura sobre esse processo entre os descendentes de japoneses, muitos fazendo o caminho inverso de seus ancestrais em busca de melhores oportunidades de trabalho.

11 Consultar também Hutter (1987) e Alvim (1986).

12 Para a noção de comunidade imaginada, consultar o trabalho de Anderson (1991). 
mantêm a confeitaria DiCunto e cujo pai Donato, voltou para seu país a fim encontrar uma esposa.

[...] diz que o caso de imigrante com moças aqui, no Brasil. esse... da sociedade não podia nem pensar [...] o imigrante era cidadão de segunda classe, então o casamento era muito difícil, entende? [...] Mesmo com famílias mais modestas não... não aprovava o casamento com. com italiano. Pra modo de dizer, que eles não sabiam qual era a conveniência, ele sabia se era... se era fugitivo de cadeia ou outra coisa. Então, esse... diz que casamento era um pouco difícil naquela época. E,. e só em 1895, meu pai volta na Itália pra casar. Casou com minha mãe e começara cosi aqui [...]

O lugar na nova sociedade era bastante claro, não lhes cabia reconhecimento nem prestígio, mesmo que se desejasse casar com famílias mais modestas. Além disso, as diferenças regionais manifestadas pela comida assustaram os imigrantes que chegavam diante da variedade de pratos desconhecidos e que formavam parte de um país que não manifestava uma representação de totalidade, ao menos naquele momento. Alfredo manifestou o mesmo estranhamento que Ana Maria ao comentar que a única massa que conhecia era o talharim, feito pela sua mãe em casa, “[...] Então, naquele tempo [...] tortelini, ravióli, era... isso a gente ouvia falar só em nome, nunca tinha visto [...] e muita coisa eu vim conhecer aqui no Brasil."

É verdade também, segundo Goody (1989), que as memórias nos oferecem caminhos às vezes tortuosos, mas sem dúvida instigante para pensar sobre a questão proposta sobre comida e identidade. Ao contrário do que se tende imaginar, a cozinha italiana deixava à mostra as diferenças que marcaram a Itália e suas distintas regiões e que se tornaram claras à medida que foram expostas ao longo da experiência imigratória no contexto urbano ${ }^{13}$.

As imigrações foram sem dúvidas portas abertas para essa nova articulação e sugeriu que esse processo poderia ser visto como espécie de domesticação, gerando maior proximidade com o novo, o diferente, o "exótico" ${ }^{14}$, mas no fundo é uma aproximação em curso, pois o exótico é tanto para aquele que vem de fora, como para aquele que já está aqui. Contudo, a ideia de domesticar sugere a hierarquia entre diferentes cozinhas, incluindo ou excluindo quem as consome. Nesse caso, o local absorveria o exógeno que, todavia, no processo observado na capital paulista levantou particularidades que destoam dessa perspectiva.

A urdidura de tramas ressalta a complexidade da análise, uma vez que não é o caso de pensar a cozinha italiana como uma fusão, assimilação ou dominação. Carneiro da Cunha(1986) já observara esse ponto, revelando que as negociações culturais dependem de fatores que superam um olhar

13 Consultar van den Berghe (1984) e van Otterloo (2002), assim como Cwiertka \& Walraven (2002).

14 Para aprofundar a questão consultar Mintz (1985), trabalho no qual analisa a trajetória do açúcar. 
superficial. E não se pode justificar apenas pelo predomínio numérico de um vasto contingente de imigrantes sobre outros menos expressivos ${ }^{15}$, pois se houve uma predileção pela comida italiana na metrópole contemporânea, outras cozinhas, como a japonesa, também adquiriram visibilidade, sobretudo recentemente, e não necessariamente estão vinculadas à quantidade de japoneses e seus descendentes ${ }^{16}$. Na verdade, o que está em jogo é recuperar elementos que possam iluminar como foram tecidas as tramas da diversidade e seu reconhecimento pela metrópole.

Nesse sentido, a comida italiana que é praticada na cidade de São Paulo foi resultado de um processo em que assimilações e descartes foram evidentes, mas em parte, revelam também como o grupo foi ocupando novas posições na sociedade. De um grupo sem coesão que precisou de traços específicos para se fazer valer em um contexto pouco favorecido, é tomado como um dos principais interventores de uma bem sucedida carreira urbana.

A cozinha preenche vácuos de novas relações entre imigrantes, sociedade local e um grupo ainda sem fronteiras claras, articulando conhecimentos, alterando-os, transportando-os para outros lugares, delimitando encontros e reforçando seu caráter relacional. Reconhecer ou estranhar necessitam desses encontros para estabelecer uma relação ${ }^{17}$, a cidade como um palco excepcionalmente fértil para evidenciar o "nós" e "o outro". A pluralidade cultural se reúne e circula com maior desenvoltura, as trocas então se acirram em distintas camadas, nem todas acessíveis, nem todas visíveis.

No caso dos imigrantes italianos do começo do século XX, além do estranhamento entre si, houve também desconfiança com relação à sociedade local. Além dos dialetos que se multiplicavam na cidade, pois o italiano como língua unificada foi um produto tardio, muitas vezes não conseguiam nem mesmo se comunicar, embora a população local tivesse nessa melodiosa língua a forma de classificar esses imigrantes como italianos que ainda os distinguiam pelas suas vestimentas e famílias numerosas.

Portanto, não é surpresa que a cozinha também fosse bastante diferenciada, embora nada seja dito em termos oficiais e manifestada de maneira mais tênue na memória de alguns interlocutores. Na verdade, uniformidade na cozinha italiana e, de modo geral, em outras cozinhas nacionais,foi acontecer à medida que surgiu uma literatura especializada ${ }^{18}$, o que era improvável circular nesse primeiro momento, inclusive porque muitos imigrantes eram analfabetos, "Então, se dizia

15 Nesse sentido, segundo dados oficiais que constam no meio eletrônico fornecidos pela prefeitura (www. prefeitura.sp.gov.br/450anos/milpovos/especial 450_grafico.htm) os números de entrada de imigrantes no período de 1872 a 1952 foi de: Italianos - 878.102; Portugueses - 460.929; Espanhóis - 395.844; Japoneses - 189.764; Alemães - 69.161; Austríacos - 39.305.

16 Conforme dados da ABRESI, os restaurantes japoneses na cidade de São Paulo cresceram nos últimos 10 anos mais de $300 \%$, sem que isso tivesse qualquer relação com a imigração japonesa, que completou seu centenário recentemente.

17 Ver Hall (2004).

18 Para a importância da literatura na construção de uma cozinha nacional consultar Mennell (1996), Pilcher (1998), Appadurai (1988). 
que naquele tempo quem sabia ler e escrever já era rei", disse Alfredo DiCunto. Armandinho do Bixiga, cujas memórias foram compiladas em Moreno (1996) ${ }^{19}$, comentou algo parecido quando levantou a relação dos paisani e política, chamando a atenção para o fato de que os italianos eram desinteressados desse assunto pela ausência de um conhecimento básico de ler e escrever. "As pessoas aqui não se interessavam pelas coisas políticas [...] Não existia, não existia, porque eram todos analfabetos [...]" (Apud:51).

$\mathrm{Na}$ ausência de um conhecimento que pudesse permitir consultar livros, os primeiros compêndios sobre cozinha italiana foram tímidos e começaram a ser desenhados no fim do século XIX, início do século seguinte por Pellegrino Artusi, cozinheiro, considerado pioneiro no sentido de dar início à unificação da cozinha italiana. Em seu livro La scienza de la cucina se percebe um esforço para amalgamar diferenças regionais, concebidas como diferenças culturais que se espalhavam pelo território como espécie de "compartimentos". Mas, pelas próprias deficiências de leitura, esse conhecimento ficou por muito tempo restrito às camadas mais favorecidas e que foram as primeiras detentoras de uma noção mais ampla da cozinha italiana.

Para Helstosky (2003) em sua análise sobre o livro de Artusi, é ele quem fala pela primeira vez em "pratos italianos". A intenção era integrar culturalmente a cozinha italiana, sugerindo uma uniformidade em função de um modelo de nação. Filippo Marinetti, outro autor importante daquele momento, tomou um caminho distinto, acreditando ser possível introduzir uma cozinha italiana a partir da intervenção política, imposta de cima para baixo. Esse debate se perpetuou ao longo de anos, inclusive, permeando as políticas em torno da alimentação sob coordenação do governo fascista.

Contudo, segundo a autora, esses cozinheiros não percebiam a Itália como um conjunto, pois as regiões meridionais praticamente inexistiam em seus livros. Com exceção da Sicília, as regiões da Calábria e da Basilicata praticamente não eram mencionadas ou conhecidas a não ser pelos figos secos e vinhos de origem grega. Contudo, vale lembrar que essas duas regiões foram as que mais enviaram imigrantes para São Paulo.

Em contrapartida, na Itália, apenas nos anos 1930 as regiões meridionais foram reconhecidas pela sua culinária em função da proliferação de alguns guias e roteiros, além do envolvimento de setores políticos. Foi também em meados dessa década que se iniciou um processo de “mediterranização" da alimentação italiana, cujo auge se deu entre as décadas de 1980 e $1990^{20}$.

Preferências regionais sempre orientaram a cozinha italiana, inclusive o molho de tomate que, segundo Capatti (2002), começou a ter maior aceitação a partir de meados do século XIX e teve, como principais difusores, os pequenos restaurantes (osterias e trattorias), um pouco mais tarde alcançando estabelecimentos mais sofisticados que, na realidade, não eram muitos. Ao contrário do açúcar que permaneceu circunscrito aos paladares mais favorecidos, o molho

19 A indicação desse livro foi dada por Afonso Roperto, outro interlocutor e que possui grande interesse em organizar a história do bairro.

20 Para uma análise desse processo, consultar Bell \& Valentine (1997). 
de tomate foi rapidamente incorporado como finalização dos pratos de massas e se popularizou em várias camadas sociais entre as regiões italianas.

Na gênese dessa comida italiana paulista, outro aspecto ausente nas memórias é a fome que seus ancestrais passaram, mesmo entre aqueles que vieram com os pais após a $2^{\mathrm{a}}$ Guerra e tinham vivido intensamente essa experiência. Mas, entre os descendentes dos primeiros imigrantes que chegaram à cidade no começo do século, essa questão da falta de comida não é pontual, talvez corroída pela erosão dos anos. A fome entre os imigrantes aparece mencionada no trabalho de Pinto (1984) ao descrever italianos e ex-escravos saindo juntos para a pesca no rio Tamanduateí e cujo intuito era conseguir o que comer. Camarões e mexilhões eram catados e preparados pelas mãos habilidosas das mulheres que em seguida os cozinhavam para alimentar a família.

No entanto, a descrição de fartura pareceria ser uma das estratégias de sedução para atrair imigrantes italianos, inclusive bastante utilizada entre as redes que costumavam ser acionadas entre parentes. Alfredo DiCunto deixou entrever esse ponto quando contou, entre as idas e vindas de sua família entre Brasil e Itália, que o marco definitivo foi seu tio ter contato sobre a abundância da terra brasileira, "nascem melancias de $70 \mathrm{~kg}$ [...] é uma terra abençoada". O que não deixa de ser um ponto instigante e que denota como as memórias percorrem caminhos tortuosos à medida que passam os anos e as gerações.

$\mathrm{Na}$ verdade, a fome ainda pairava nos primeiros tempos, mas era contornada à medida que as hortas prosperavam nos fundos das casas e cortiços, além das criações de galinha, formas de produzir alimentos básicos para a família rapidamente reproduzidos entre os italianos na cidade. “Todos tinham o quintal, o galinheiro, umas frutas, o chuchu (um chuchuzão!) E era tudo vindo da Itália. Eu me lembro que vinham aqueles queijos da Itália [...]" (Moreno: 39-42). Na verdade, o Brasil não oferecia fartura no sentido que parece figurar nas ideias dos interlocutores, mas ao menos, tampouco deixava passar fome. Era possível encontrar os itens mais fundamentais que atendiam os padrões alimentares desses imigrantes, embora com usos flexibilizados.

Nesse sentido, a ideia de fartura é uma condição constante. Falando sobre o Brasil, Domenico Laurenti, dono da padaria Basilicata, afirma:

[...] é muito bom. Aqui passa mal só quem não quer trabalhar. O resto tem de tudo: comida aqui de sobra, comida aqui... tem muita gente que passa fome. Por quê? Eu não sei. Porque, bom [...] aqui embaixo tem mais de dez metros de terreno, por que não planta salada? Por que não planta pé de milho? Por que não tem uma galinha? Na minha terra, tudo isso na minha terra é assim, tinha tudo, não sobrava terra, nem dois palmos de terra.

A fartura é uma ideia que penetra nos poros e nas narrativas, mas quem soube aproveitar foram os imigrantes, como afirmou outro interlocutor, Nunziato Petrizzo que concorda e ainda reafirma como esses laços de solidariedade foram importantes ante o novo, 
[...] a nossa comunidade aqui era enorme. Muito solidária, se ajudavam uns aos outros... e adoravam fazer festa [...] não eram festas chiques, mas havia fartura. Não faltava nada, ninguém saía de lá com fome. [...] Eram esforçados, eram batalhadores... trabalhavam menos do que na cidade deles... então era talvez até mais fácil para eles exercerem essas funções que hoje diria eu seriam pesadas, puxadas.

Entretanto, a terra prometida não foi exatamente dadivosa e não foram raros sentimentos ambíguos com relação ao local e à terra natal. O trabalho era uma condição necessária para chegar à fartura, ou seja, prosperidade. Para tanto, os italianos não se negavam a colaborar com aqueles que estavam em condições menos favoráveis, uma solidariedade étnica que criou uma vasta rede de ocupações. A fartura de alimentos não foi exatamente uma constante ${ }^{21}$, pois só foi sendo incorporada ao imaginário da cozinha italiana à medida que imigrantes prosperavam.

Inclusive, para aqueles que vieram do campo, a abundância não era corriqueira, como deixou entrever Giulia Piastrelli em algumas passagens de seu depoimento:

[...] passar fome era comum, mesmo no campo [...] Então, a gente no verão pegava as folhas da árvore da castanha e fazia uns macinhos depois deixava secar e amarrava, né, cada macinho dessa folha deixava secar. Depois, fazia uma, que nem um colar digamos, enfiava um no outro, deixava secar essa folha. Quando chegava o inverno [...] se pegava um maço dessas folhas e se deixava de molho. Em uma tigela, a gente desmanchava a farinha de castanha e deixava esquentar [...] Quando estava bem quente a gente punha uma pedra, as folhas e depois punha um pouco daquela mistura de farinha, né, cubria com outra folha, punha outra pedra em cima, assim se fazia [...] e se comia aquilo com queijo, com linguiça, com coisas assim né. Fritada, fazia omelete, essas coisa, essa era o alimento principal.

A fome era uma realidade bastante presente, no entanto não evocada, ao menos no imaginário local, como se percebe na citação de Lemos (2001) ao reproduzir uma passagem de Raffard, mineiro a passeio em 1902 pela cidade, dá conta da ironia com que essa comida era percebida,

[...] Vinhos, pães, automóveis, roupas, tecidos, anúncios, tudo é em italiano. Nos empórios vêem-se montanhas de latas de tomate siciliano e de massas napolitanas; nas lojas de tecidos figuram todos os nossos algodões da Lombardia, as nossas sedas de Como, os nossos chapéus de Florença e Alessandria. (2001, p. 9).

$21 \quad$ A visão do país que os recebeu como um paraíso é também mencionada por Petrone (2001). Baily (1999) também notou esse aspecto em seu estudo comparativo entre Buenos Aires e Nova York que vê nesse processo uma reconfiguração do processo de imigração. Para ele, se existia uma intenção de fazer com que esses imigrantes fossem assimilados, essa postura mudou ao longo do tempo e se passou a pensar o processo desde uma perspectiva de valorização da pluralidade cultural, o que afeta sobremaneira a impressão que é feita desse encontro entre sociedade local e imigrantes. 
Produtos italianos, "montanhas" de fato não condizem com a ideia de escassez. De fato, se não faltava comida à mesa, também não era porque existia abundância para desperdiçar. O medo de faltar comida pode ter sido um fator que afetou os primeiros tempos da cozinha italiana na capital paulista. O tripé - pães, massas e pizzas - era a base, mas contava com a companhia de outros produtos importados como azeite de oliva, azeitonas, vinho e queijos ${ }^{22}$, apreciados com moderação, pois a abundância ainda não era acessível, ao menos nos parâmetros que marcariam essa cozinha.

Tampouco houve uma ruptura abrupta com os laços que uniam os imigrantes ao seu país natal, inclusive nessas idas e vindas constantes existia um intercâmbio de ideias e representações de grande porte. Nesse sentido, a presença de Mussolini em algumas narrativas já aponta para esse diálogo e é preciso atenção para não descartar a forte influência exercida sobre os imigrantes, especialmente quando se difundem ideias a respeito da alimentação e a valorização da frugalidade. A austeridade era um estilo de vida e rapidamente revertido a discurso político pelo Duce, especialmente quando o País beirava o caos alimentar, uma vez que a situação não era das melhores antes da $1^{\text {a }}$ Guerra e piorando logo em seguida.

A frugalidade era pregada continuamente, sendo alguns itens valorizados com maior intensidade: pão, massas, verduras e legumes, frutas e carne apenas como um item para dias de festa. Para os peninsulares esse discurso não diferia muito de sua realidade cotidiana, massas secas, molho de tomate e pão já circulavam com bastante desenvoltura desde o fim do século XIX e rapidamente foram os itens que marcaram a alimentação de imigrantes no Brasil ${ }^{23}$. As diferenças regionais permaneceram latentes, no entanto para a sociedade local massas e latas de molho de tomate eram visões no mínimo, exóticas, além de traduzir um fenômeno em pleno andamento na cidade, ela estava sendo tomada pelos imigrantes e sua diversidade, nem sempre bem recebida.

Exemplos de Ana Maria Carrer e Alfredo DiCunto evidenciam esse constante contato entre imigrantes e terra natal. Contudo, a sensação descrita por muitos imigrantes era de que faltava algo quando se estava aqui e faltava algo quando se estava lá24 . Ao mesmo tempo em que a cidade os abrigava, sentiam falta da Itália deixada para trás. Armandinho do Bixiga descreve esse sentimento em suas memórias (MORENO, 1996) claramente entre seus amigos do Bixiga :

22 Helstosky (2004) afirmou que estes produtos, inclusive, encontraram maior volume de vendas após a $1^{\mathrm{a}}$ Guerra mundial, sendo seu principal mercado consumidor os Estados Unidos.

23 A mesma autora sugere que isso aconteceu não só no Brasil, mas também nos Estados Unidos e na Argentina.

24 Para Ianni (1972), todos sem exceção imaginavam um dia voltar e frente a isso as implicações seriam sentidas de imediato na forma de levar o dia-a-dia em seu novo país. Havia ainda, segundo ele, um sentimento de inferioridade pelo fato de ter saído da terra natal para tentar a sorte em outro lugar e teriam como objetivo retornar de modo triunfal, nem mesmo que fosse para uma breve visita, mas que os sinais de prosperidade ficassem evidentes. 
[...] Nunca existiu um casamento tão perfeito entre italianos e paulistas. Você sabe que eu nunca vi, eu não conheço entre esses italianos que vieram no início do século, um que dissesse: 'Eu vou para a Itália'. É o contrário: 'Eu nunca mais na minha vida'. [...] E diversos que foram visitar a Itália, até hoje, quando voltam, eles falam: 'Armandinho, depois de 15 dias eu não via a hora de pegar o avião e voltar para São Paulo’. (1996, p. 83)

Outro fator que afeta a disponibilidade de informações são as atitudes que gerações anteriores podem ter alimentado com relação às suas intenções de permanecer no país ou retornar. Isso implica, também, diferentes formas de lidar com a adaptação, uma vez que o esforço em criar vínculos locais dependia de uma perspectiva que envolvia permanecer definitivamente ou apenas temporariamente. Muitos apenas imaginavam estar de passagem e isso estabelecia, inclusive, relações familiares bem diferentes, até com relação ao dinheiro e uso de economias ${ }^{25}$.

Entre os italianos do início do século XX, não era incomum que muitos voltassem para se casar, como os exemplos de Ana Maria Carrer e do pai de Alfredo DiCunto deixaram entreve, assim como muitos vinham sozinhos para se organizar e mandar buscar o restante dos membros. Os casamentos dificilmente se faziam entre estrangeiros e sociedade local, hábito que só começou a se observar quando italianos ascenderam economicamente e se uniam às famílias de elite locais, algumas depauperadas pela decadência do café. O preconceito era mútuo, italianos preferiam membros da comunidade e a sociedade local nem sequer aventava a possibilidade de uniões com esse tipo de gente ${ }^{26}$.

Esse ponto criou uma dificuldade extra no sentido de perceber o ritmo expositivo das memórias, ao confrontar as narrativas dos interlocutores e dados disponíveis em relatos de memorialistas, observadores do cotidiano, permitiu perceber que a memória tem entre suas estratégias pensar sobre a diferença e como ela se interpõem em distintos projetos ${ }^{27}$.

Curiosamente, as tensões desapareceram e periodicamente as lembranças evocam a ideia de progresso e trabalho, cultivando uma maneira própria de ser italiano. Contudo, a incorporação dessa imagem foi fortalecida décadas mais tarde, em parte pelas mãos dos descendentes e imigrantes mais preparados que vieram ao findar a $2^{\text {a }}$ Guerra. Essa concepção está associada também à ascensão social que muitos italianos conquistaram, embora pudesse ser considerado também como um fator estrutural daquele momento, uma vez que com o crescimento econômico e abertura de fábricas criaram oportunidades de ocupação antes nunca vistas.

25 Baily (1999) notou essa diferenciação nos processos que analisou em Buenos Aires e Nova York.

26 A visão romântica da assimilação e aceitação dos estrangeiros é ressaltada em alguns autores como Cenni (2003) que não poupou elogios à contribuição italiana e viu nos casamentos uma forma de estreitar relações com a sociedade local, "uma tendência natural", segundo o autor. Há escassez de dados, mas algumas estatísticas indicam que havia maior probabilidade de união entre homens italianos e mulheres brasileiras do que o contrário o que sugere um caminho ainda não explorado.

27 Consultar Klein (2000). 
O próprio retorno, mesmo para aqueles que contavam com algum capital acumulado, era muitas vezes uma decisão postergada em favor da economia para a velhice. Por outro lado, quando ocorria o retorno para visitar a família, era preciso dar sinais de prosperidade, como frisou Ângelo e comentou de suas várias idas à Itália, sempre recebido com muita pompa.

Um ano depois que cheguei ao Brasil comprei um carro, é! [...] Ma quando cheguei ao Brasil morria de saudades da Itália. Já voltei oito vezes para Itália, si! Só para passear [...] Fizeram uma praça em homenagem a mia família, chama Praça Luisi.

Desse modo, a ideia de frugalidade pode ter sido reavaliada frente às condições que se apresentaram localmente e até manter um padrão compatível com a realidade encontrada na terra prometida. Ao invés da fartura, condições precárias de vida e inclusive à mesa demandavam o uso apropriado de recursos para não cair em uma situação de extrema miséria. Nesse sentido, as dificuldades enfrentadas nos primeiros tempos ao invés de servirem como inspiração para a retórica comum desses imigrantes, foi substituída pela ideia de trabalho, ficando o fardo encontrado em segundo plano.

Por outro lado, uma característica de ambas as cozinhas parece ter favorecido esse encontro, a monotonia, que no caso italiano se observava na utilização de poucos ingredientes em múltiplas receitas $^{28}$, ao contrário do caso paulistano que se concentrava no consumo de arroz, feijão, alguma carne e raramente alguma verdura ${ }^{29}$. Na verdade, a fartura estava muito mais ligada à quantidade de comida, do que efetivamente à variedade, uma característica que, inclusive, delineou uma particularidade da cozinha italiana praticada na cidade de São Paulo.

Essa característica permaneceu firme ao se notar os diferentes usos dados a um mesmo ingrediente, a farinha de trigo transformada em pão, massas e pizzas. Esse ponto é também mencionado por Nunziato Petrizzo quando se lembrou da berinjela, espantado com o fato de que em São Paulo pouco se consumia verduras e legumes. No entanto, não só não existiam muitas verduras e legumes, como não se faziam variações sobre um mesmo ingrediente, algo que o deixou profundamente intrigado e marcou uma diferença entre nós e os outros.

Ele chamou a atenção para a simplicidade da cozinha italiana,

[...] um manjar dos deuses [...] nosso macarrão... minha mãe fazia artesanalmente, tudo... tudo... nossa comida é fantástica. É uma pena que eu perdi minha mãe e isso venha se perdendo também. Existe algo similar aqui, mas não se igualava ao que produzíamos lá. Nosso pão... os legumes que em São Paulo eram pouco conhecidos, a berinjela, por exemplo, que hoje é uma coqueluche, digamos, naquela época não se conhecia berinjela e nós comíamos berinjela de 50 maneiras [...] Tudo era muito simples... e nós trouxemos todas as nossas coisas de lá [...].

28 Esse aspecto é discutido por Capatti \& Montanari (1999) e também Helstosky (2004).

29 Bruno (1954) se refere a esse aspecto na capital paulista. 
Rapidamente alguns elementos da cozinha italiana foram resgatados na nova sociedade e muitos produtos foram reproduzidos por meio dos conhecimentos de cozinha, especialmente pelas mãos das mulheres. Essa produção étnica sustentou uma ampla rede de troca e venda de alimentos que foi descrita em diversos momentos por memorialistas ${ }^{30}$, um comércio praticado por estrangeiros e entre estes um vasto contingente de italianos ${ }^{31}$. De fato, a questão da fartura dependia diretamente do trabalho e nem sempre essa relação se estabelecia de modo direto, como Domenico Di Laurenti deixou claro ao descrever sua surpresa ao ver entre "brasileiros" a falta de preocupação com a comida. Ele acredita que tanto "brasileiros" como "estrangeiros" que desejam trabalhar prosperam, mas não compreende como há tanta gente passando fome quando sobra terra para plantar.

Na Itália não havia um único espaço sobrando, nos pequenos trechos de terra havia algo plantado, bem como algum tipo de criação de animais. Era uma questão de aproveitar o que a terra proporcionava, bem como trabalhar, dois aspectos muito presentes na fala dos interlocutores. A fartura não viria sem trabalho e para os italianos parece que chegou com força, pois esse empenho nunca lhes faltou. A forma como os italianos encontraram respostas à adversidade pelo trabalho também é evidenciada na fala de Francisco Savoldi,

[...] vamos parar de pensar que o imigrante só plantou café.[...] Isso é mentira [...]. Isso foi uma das partes da imigração. Eles eram maltratados, eles não ficaram lá [...]. O escravo era patrimônio do fazendeiro, ele deveria tratar bem, em tese. O imigrante não, o imigrante dava o seu trabalho. Eles fogem da zona rural, ele veio para a zona urbana, aí eles vieram para cá, para São Paulo. E é o nascimento dos alfaiates, dos artesãos, dos jornaleiros, de todo esse pessoal.

O trabalho sempre foi um aspecto central nas narrativas. Com o declínio do café e a indústria incipiente, cuja mão de obra estava disponível nos braços estrangeiros, constituiu uma forma de ocupar milhares de imigrantes instalados no meio urbano. E ante esse quadro, mal tinham tempo para descansar, inclusive porque a separação entre lazer e trabalho era uma linha praticamente indistinguível. O impulso do cotidiano imigrante, mesmo errático aos olhos das camadas

30 Entre não só memorialistas, mas analistas das interações entre imigrantes e população local nesse período, os mais utilizados foram: Americano (1962), Bruno (1954, 1984), Diaferia (2002), Freitas (1985), Grünspun (1979), Lemos (2001), Moreno (1996), Penteado (2003), Ribeiro (1994) e Sesso Jr. (1995). Para uma análise da obra de Ernani Silva Bruno, consultar Lofego (2004). Outro autor que observou essas novas relações foi Juó Bananaré, ou Alexandre Marcondes Machado e sem dúvida o mais sarcástico, tendo descrito com humor agudo e desafiador o dialeto macarrônico que predominava na cidade, publicando seus textos em veículos como o periódico humorístico O Pirralho e mais tarde reunidos no livro La Divina Increnca. Além destes, foram interessantes também os livros de memórias de alguns interlocutores como Mario Tatini, Giovanni Bruno, Angelo Luisi, Antonio Buonerba entre outros que, embora sem mencionar aspectos negativos de sua adaptação à cidade, oferecem uma visão bastante particular de sua contribuição e trajetória na formação de uma identidade urbana, bem como de sua italianidade.

31 Curiosamente, os memorialistas pouco apontaram para a presença de outro grupo bastante desfavorecido na cidade, os ex-escravos, focando sua atenção aos imigrantes, "brancos e europeus", e deixando sob sombras uma vasta parcela de população, como argumentou Santos (2003). 
favorecidas locais, era o trabalho. Domenico Laurenti frisou em vários momentos que "naquele tempo não se separava trabalho de lazer [...]", ou seja, a vida cotidiana não separava, como hoje, o trabalho do lazer. Esse ponto é referendado por Alfredo DiCunto, quando questionado sobre seu tempo livre "Eu não tinha isso, eu..é eu trabalhava". Armandinho observou que

[...] tudo que meu pai ganhava era para comer e pagar nossa escola, só para isso. Era assim em todas as casas. Naquele tempo não tinha mendigo, ninguém pedia esmola, ninguém passava fome [...] Aqui no Bixiga, que era um bairro pobre, todo mundo tinha sua casinha (Apud: 38$)[\ldots]$ O que eles queriam era comer bem, dormir bem, viver bem e cuidar da família. O resto que se frega. (1996, p. 51)

Trabalho e lazer pouco se diferenciavam, na verdade esse aspecto ficou ressaltado quando as fábricas implantaram a jornada de trabalho que, inclusive, a princípio não era regida por qualquer lei ou convenção a não ser do patrão. Ir ao cinema ou ir à confeitaria eram programas de grande importância e raros, embora pela quantidade de italianos que circulavam pela cidade proporcionasse uma impressão distinta, como denotou Monteiro Lobato (apud Carelli,1985: 127):

O Brás trabalha de dia e, à noite, dorme. Aos domingos, fandanga ao som de bandolim. Nos dias de festa nacional (destes tem predileção pelo 21 de abril: vagamente o Brás desconfia que o barbeiro da Inconfidência, porque barbeiro, havia de ser um patrício), vem a S. Paulo. Entope os bondes no travessio da Várzea e, cá, ensardinha-se nos autos: o pai, a mãe, a sogra, o genro, a filha casada no banco de trás; o tio, a cunhada, o sobrinho, o Pepino, voluntário, no da frente; filhos miúdos por entremeio; filhos mais taludos ao lado do chauffeur; filhos engatinhantes embaixo dos bancos, filhos em estado fetal no ventre bojudo das matronas. O carro, vergado de molas, geme sob a carga e arrasta-se a meia velocidade rua acima, exibindo a Paulicéia aos olhos arregalados daquele exuberante cacho humano. Finda a corrida, o auto debulha-se do enxame no Triângulo e o bando toma de assalto as confeitarias para um rega-bofe de spumones, sisis, croquetes. E tão sério toma a tarefa que, ali pelas nove horas, não resta mais vestígio de empada nos armários térmicos, nem sorvete no fundo das geladeiras. O Brás devora tudo, ruidosa, alegremente e sai impando bem-aventurança estomacal, com massagens ajeitadoras do abdômen. Caroços de azeitonas, palitos de camarões, guardanapos de papel, pratos de papelão seguem com ele, nas munhecas da petizada $[\ldots]$

Em seguida vão para o cinema! Abarrotam os de sessão corrida.

Pela descrição não é possível descobrir se esse costume era rotineiro entre imigrantes italianos, mas é fato que pela quantidade de estrangeiros que circulavam pela cidade sua presença se fazia sentir de modo intenso, dando-lhe um caráter quase superlativo na apropriação do espaço urbano. Se Monteiro Lobato apontou para essa particularidade, seriam os modernistas que tornariam essa temática central, inclusive como bem explorou Juó Bananaré em suas crônicas do cotidiano junto aos imigrantes e seu dialeto macarrônico. 
O divertimento era raro, mas não ficou resumido ao centro, frequentado pelas camadas mais privilegiadas, mas também nos bairros de imigrantes que em poucos anos se transformaram em proletários. Nesse sentido, outro caminho em que se reforçava a italianidade eram os encontros nos clubes recreativos e as competições esportivas adquirem força entre a sociedade local. Eram comuns as corridas de cavalos nos hipódromos, assim como um hábito muito popular eram os piqueniques coletivos ${ }^{32}$.

Entretanto, a ida ao cinema ou a uma confeitaria era uma atividade mais característica de exceção, segundo sugere Luca (1990), pois de fato os encontros além do trabalho eram mais nítidos nos bailes ou festividades promovidos pelas associações ou sociedades que agremiavam italianos, além das tradicionais festas religiosas.

De fato, os imigrantes que chegavam sabiam o destino que lhes era reservado, e muitos sucumbiam aos apelos de parentes que já estavam instalados em São Paulo que conseguiam encaminhar os novos imigrantes em distintas ocupações. Tios que chamavam sobrinhos, filhos que buscavam pais, irmãos que traziam irmãos são referências assíduas nas memórias dos entrevistados. Alguns traziam alguma experiência profissional, embora nem sempre fosse possível compatibilizar essa disponibilidade com as ocupações existentes. O próprio Alfredo DiCunto era especialista em carpintaria, mas em função das condições existentes, deu continuidade ao negócio do pai, a padaria. Outros seguiram caminhos semelhantes em função das oportunidades que surgiam.

Dessa forma, foram sendo formados agrupamentos de italianos em alguns bairros da cidade como Brás, Mooca, Bom Retiro, Belenzinho - estes tendo a via férrea como espinha dorsal - Cambuci, Bela Vista (Bixiga) ${ }^{33}$, bairros afastados do centro da cidade de São Paulo e que ficaram conhecidos como bairros de imigrantes. Brás e Mooca, à época a mesma coisa, foram os que abrigaram inúmeros imigrantes, uma vez que ali encontravam outros patrícios com origens semelhantes. Alguns anos mais tarde foram esses bairros que marcaram o início da industrialização da cidade e concentrou um número ainda maior de estrangeiros ${ }^{34}$. Nesses bairros os vínculos emergiam: vizinhança, trabalho, reconhecimento solidário determinavam os ritmos desses espaços.

$32 \quad$ Segundo Americano (1954), o primeiro deles foi promovido pelo Clube Mozart, sediado no Brás e realizado na cidade de Mogi das Cruzes que fizeram seu passeio através da Estrada de Ferro do Norte. Sem querer ficar atrás, o Clube Recreativo, também no Brás (Rua do Gasômetro) promoveu um piquenique em Jacareí. Leite (2001) trabalhou com a questão do uso de fotos históricas e descobriu várias imagens de piqueniques, revelando que essa situação era mais comum do que se pensava. Um momento normalmente retratado de maneira festiva em famílias em que, geralmente, as fotos eram mais solenes. Esse ponto foi narrado por um dos meus interlocutores e de fato corroborou a importância desses piqueniques na vida familiar, assim como os passeios ao hipódromo da Mooca para assistir as corridas de cavalo. Sobre a importância dos piqueniques, consultar também Csergo (2003) que trabalhou esse tema e gentilmente discutiu essa questão comigo no $1^{\circ}$ Colóquio Saberes e Sabores realizado em Curitiba, Paraná em agosto de 2007.

33 Consultar mapa de São Paulo, no Anexo, Apêndice 3.

34 Para mais detalhes, consultar Paoli \& Duarte (2004). 
Contudo, os profundos regionalismos desses imigrantes, ao menos a princípio, não foram abandonados. As disputas entre regiões eram trazidas à tona, especialmente nas comemorações religiosas, rituais que foram associados aos distintos grupos e bairros da cidade. No Brás, muitos nativos de Bari se instalaram e logo iniciaram as comemorações de seu santo, São Vito; no Bixiga, predominantemente de calabreses, tinham a festa dedicada a Nossa Senhora da Achiropita. Na Mooca, com italianos do sul, além de espanhóis e húngaros, fazia vista com homenagem a São Genaro.

Apoiados por esses vínculos étnicos, muitos italianos assim que chegavam à cidade procurava alguma forma de trabalho e, em geral, optavam por algum tipo de comércio ambulante. Os que dispunham de algum capital tentavam a sorte com estabelecimentos modestos.

Mas são fases distintas que se mesclam nas lembranças dos interlocutores, pois tendem a reforçar uma percepção positiva em torno de sua acolhida, salvo uma ou outra exceção. $\mathrm{Na}$ realidade, essa nova população foi acolhida de bom grado como elemento civilizador e de certa forma "branqueador" à medida que substituíam a mão de obra escrava nas fazendas. Entretanto, à medida que não se interessavam em permanecer sob o domínio de fazendeiros que ainda estavam presos à mentalidade escravocrata, os imigrantes preferiram a cidade. Nesse momento, até então tidos como instrumentos de progresso, ganharam uma nova conotação bastante pejorativa e em geral associados à violência, sujeira, desordem.

Em parte, essa percepção ganhou força à medida que mais e mais estrangeiros se radicavam na cidade que não oferecia condições suficientes para abrigar repentinamente semelhante contingente humano. Essa explosão demográfica trouxe diversos problemas e, em especial, o das moradias ${ }^{35}$. As regiões mais afastadas do centro como os bairros que ficariam conhecidos por abrigar fábricas, operários e imigrantes viram brotar por toda parte moradias coletivas que durante anos foram alvo de políticas higienistas.

Não foi sem algum motivo que começaram a emergir habitações coletivas, uma continuidade da senzala nos dizeres de Lemos (1990), em que ao invés de escravos, multiplicavam-se trabalhadores assalariados. Eram os cortiços, localizados em bairros afastados do centro e próximos à via férrea. Lugares imundos e de convívio coletivo, corresponderam a uma solução imediatista ao problema de acomodar esse contingente de novos moradores, embora assim

35 São Paulo, segundo Trento (1988) teve um crescimento expressivo em um curto período de tempo em função do número de imigrantes que chegaram. Em 1872, a cidade contava com 23.243 habitantes e pulou para 44.030 (1886), 64.934 (1890), 130.775 (1893), 239.820 (1900), cerca de 400.000 (1914), 579.033 (1920), 1.060 .120 (1934). Ressaltando, ainda, que em 1920 quase $2 / 3$ dos habitantes da cidade eram estrangeiros ou descendentes, sendo que os italianos representavam mais da metade da população adulta do sexo masculino. Os bairros considerados operários, em função das inúmeras fábricas que ali se instalaram pelas facilidades de acesso geradas pela estrada de ferro, foram privilegiados entre os imigrantes para moradia, de modo que Brás, Barra Funda, Belenzinho, Bom Retiro concentraram muitos italianos e em menor quantidade espanhóis e portugueses. Fora do eixo industrial, mas próximo ao centro, estava a Bela Vista, ou popularmente Bixiga, destino também selecionado pelos italianos para morar, na época acompanhados por muitos ex-escravos que ali se instalaram. 
que pudessem, procuravam casas individuais, em geral sobrados geminados construídos pelos imigrantes.

Era um incômodo a presença desses novos habitantes com uma língua sonora e barulhenta, amplas famílias, com costumes diferentes, além de vestimentas estranhas, embora contidos fora dos bairros considerados elegantes como o Centro, Higienópolis, Campos Elíseos e proximidades da Avenida Paulista ${ }^{36}$. E a pacata cidade de mentalidades e fronteiras fechadas se viu subitamente tirada de seu cotidiano modorrento ao receber, em disparada maioria com relação a outros estados, imigrantes de várias nacionalidades e entre estes, inúmeros italianos.

Na verdade, a busca pela mão de obra europeia e branca alimentava uma crença de que essa diversidade cultural traria benefícios para a cidade, embora cotidianamente a relação com os imigrantes fosse bastante diferente. Gerando novas experiências no espaço urbano e evidenciando a diferença cultural, é nesse contexto histórico que surgem usos da cidade em diferentes ritmos e temporalidades determinando formas de sociabilidade bastante distintas daquelas até então observadas $^{37}$. Os imigrantes eram uma engrenagem de um grande mecanismo, mas apesar disso tinham de organizar sua vida de todo dia.

Essas cadências e enfrentamentos raramente são mencionados pelos interlocutores, uma dificuldade que é revelada de maneira mais direta em algumas menções de Alfredo DiCunto que ouviu de seu pai comentários a respeito do tratamento que os italianos recebiam, "um pouco melhor que escravos". Ante toda esta nova experiência, a comida encontrou um espaço para vicejar como um importante instrumento de identidade.

A conjunção desses distintos planos começou a modelar um sentido de italianidade, ainda rudimentar e segmentado em função das relações que se enfrentavam, mas que se fazia necessário para lidar com os inúmeros obstáculos que se apresentavam. A constituição de um elo em comum ainda estava sendo moldado em uma realidade que, apesar dos discursos positivos em torno da imigração, escondia um profundo preconceito. A comida perpassava por todos esses aspectos.

Da perspectiva de João Donato, proprietário da Pizzaria Castelões instalada no bairro do Brás desde 1924, na Rua Jairo Goés, essas desavenças parecem não ter existido. Ele fala do bairro do Brás com nostalgia e não se esquece dos momentos festivos que transcorriam na rua. Ali viveu sua infância e boa parte de sua vida adulta, tendo-se mudado para o Tatuapé, bairro próximo há alguns anos. Mas disse sentir muita falta das amizades, das relações que cultivou ali. Ele contou que:

$36 \quad$ Consultar a análise de Carelli (1985), embora fale sobre ascensão social dos imigrantes, oferece uma ampla retrospectiva das obras escritas naquele momento tomando como tema a imigração e, em especial, os italianos.

37 Consultar artigo de Koguruma (1999). 
Sabe, o Brás era muito romântico, Caetano de Pinto de italianos e Carneiro Leão dos espanhóis. Não era a sujeira de hoje [...] Era uma família, não era o cortiço de hoje, chegava a Páscoa e cada um fazia uma coisa e trocavam os pratos, comemoravam a data juntos. [...] Tinha os vendedores, eu vi, um senhor que andava com barris de lata, um jaleco branco, gorro branco vendendo pizza. Eu me lembro disso com meu pai, no campo do Juventus, na rua Javari. Doze pizzas de meio a meio! Virava a tampa e cortava. Tinha o vendedor de canolis, uma ponta de chocolate e outra de creme. [...] De noite era comum a gente ouvir algum menino fazendo seresta para a moça, conhecíamos todo mundo.

Curiosamente João não descreveu o Brás da mesma forma que muitos memorialistas, ao contrário, ele possui uma visão idílica e sua ideia de sujeira é em função de um fenômeno recente, a entrada dos nordestinos. Sua narrativa aponta ainda para uma separação simbólica do Brás e da Mooca, naquele momento um bairro único. Era a Avenida Celso Garcia que separa os espanhóis da Mooca dos italianos do Brás. Lembrou que nesse momento a avenida era uma das mais elegantes, com cinemas e teatros, além da Confeitaria Guarani, onde seu pai trabalhou. Memórias semelhantes emergem nas falas de Pedro Porta, que mostrou a documentação original do terreno comprado por seu sogro, Alfredo DiCunto, onde até hoje está a Confeitaria DiCunto e para onde foram construir o prédio na padaria, acreditando nas indústrias que por ali se instalavam.

Tanto João como Pedro estimavam as relações de proximidade estabelecidas com os vizinhos e moradores do bairro, algo que eles julgam desaparecido do mundo contemporâneo, opinião compartilhada por outros interlocutores. O bairro era onde se trabalhava, onde se passeava, onde se faziam festas e encontros. As casas misturavam membros da família e vizinhos, companheiros de trabalho, recebiam vendedores e forneciam produtos para a venda.

Armandinho do Bixiga também aponta essa característica em seu bairro:

[...] Aqui no Bixiga era uma Itália [...] Aqui era uma miniatura da Itália (Apud: 48) [...] O Bixiga é um bairro com muitos italianos, com uma presença forte de italianos, mas não somos exclusivamente italianos ou descendentes [...] E eu falo para todo mundo que o Bixiga talvez tenha sido o único bairro tipicamente italiano, porque o Brás tinha espanhóis de montão, chegavam quase a rivalizar com os italianos, o Bom Retiro tinha outras raças e o Bixiga não: tirando a Saracura, era $100 \%$ ou quase de italianos. (1996, p. 87-88)

A concentração de italianos em determinadas regiões teve como desdobramento a partilha de um sentimento de pertencimento, como se pode observar nos trechos de alguns interlocutores. Entre o fim do século XIX e o início do século XX, São Paulo perdia suas características interioranas e atraía fazendeiros e comerciantes prósperos. A cidade se transformou em um campo de obras em um afoito crescimento desordenado, como observou Americano (1954). Acompanhando as mudanças na paisagem urbana, não foi de estranhar que alguns bairros 
servidos pela estrada de ferro e onde preferencialmente se instalavam as indústrias se tornassem endereços preferenciais dos imigrantes.

Como eram bairros recentes, o cenário não era dos mais organizados. Misturavam-se fábricas e residências, não existiam regras de urbanização. Naquele momento não era raro ter fábricas ao lado de residências em uma mistura profícua de trabalhadores e moradores. Casas modestas, pequenos comércios, fábricas eram dispostos sem uma sequência definida em que se pudesse saber o que viria a seguir.

A vida nas ruas recriou, em alguma medida, formas de sociabilidade assentadas nas origens de seus novos habitantes, embora não deixassem as ambiguidades de lado. Nesse sentido, a cidade de São Paulo se pretendia uma metrópole multicultural e sua auto-imagem não abria espaço para todos. A ideia de modernidade que se desejava para a cidade era inspirada em hábitos e costumes europeus, partindo de um mercado de trabalho assalariado, de feições brancas. Mas, as distintas dinâmicas sugerem que a assimilação, apesar de ser percebida como natural, em momento algum foi livre de conflitos ${ }^{38}$.

Essa divisão da cidade também tinha como intenção classificar as classes trabalhadoras e acabou por estimular a proximidade entre patrícios, trazendo como uma consequência a facilidade de acesso aos gêneros alimentícios que dialogavam com a Itália. Foram nesses bairros que surgiram as primeiras produções artesanais de massas e pães. Foi também um momento favorável para um intenso sistema de trocas entre distintas famílias e grupos regionais que encontram na comida uma forma de estabelecer reconhecimentos e distâncias, embora tentando estabelecer um conjunto de elementos que pudesse fazê-los visíveis no novo contexto urbano.

A família jogava um papel importante e em muitos exemplos era o principal meio de produção econômica capaz de garantir alguma estabilidade na sobrevivência cotidiana. E nesse caso, a mulher desempenhou um papel importante na produção e circulação de gêneros alimentícios, embora raramente apontado dessa forma. É sabido, de maneira genérica, que a cozinha italiana chegou pelos italianos e que estes criaram rápidas formas de abastecimento para poder atender às práticas alimentares. Nada é mencionado sobre o papel das mulheres, a não ser de maneira tangencial.

Nesse sentido, há menções constantes às mammas ou nonnas ${ }^{39}$. Eram referidas como grandes cozinheiras e foi a partir desse ponto que se percebeu que não estavam restritas unicamente ao universo doméstico, ao menos quando a partir de seu conhecimento e trabalho começaram a servir outros imigrantes em pequenas mesas frente aos cortiços dos bairros étnicos. Eram os embriões do que mais tarde seriam as cantinas.

38 Santos (Op.Cit.) abordou a questão da distribuição social nos bairros paulistas: bairros elegantes, os populares e o centro e no intuito de modernizar a cidade o autor argumenta que houve a intenção de especializar a cidade e circunscrever quem eram os trabalhadores e quem não.

39 O termo mamma refere-se às mães italianas, em geral, mulheres dedicadas à vida doméstica e com grande habilidade na cozinha, assim como as avós (nonnas). 
As mammas foram personagens principais dessa nova cozinha ao trazer consigo saberes e sabores da Itália, uma comida de origem caseira, muitas vezes de origem rural e muito apegadas à visão do núcleo familiar como principal meio econômico de sobrevivência. São várias as referências nesse sentido, nunca ditas de maneira direta, pois era considerado um trabalho alternativo para conseguir melhores condições para a família. Anitta Concetta de Caro Santos lembrou que na época

\begin{abstract}
Minha mãe para ajudar começou a fazer macarrão para fora e naquela época não tinha máquina de macarrão, como tem hoje de massas [...] e fazia macarrão para fora, era tudo manual também. Então ela fazia muito para a Cantina Balila. E a gente também ajudava porque nós estudávamos no Grupo Romão [...] e ela fazia macarrão e a gente também ajudava um pouquinho. Ela trabalhou muito, mas muito mesmo. [...] Era bem natural.
\end{abstract}

Impossível saber se todas as mulheres detinham o conhecimento do cozinhar, mas as narrativas tendem a reforçar a presença feminina na cozinha e seu envolvimento como fundamental na constituição e reprodução da cozinha italiana. Há também um evidente reforço do trabalho e ajuda da família, valores considerados importantes por praticamente todos os entrevistados.

Além disso, cozinhar não é tão simples como parece à primeira vista. Inicialmente é preciso organizar mentalmente o que será feito, decidir os ingredientes e quais as técnicas que serão empregadas. É claro que essas etapas à medida que se tornam habituais passam despercebidas, mas requerem um conhecimento específico para serem concluídas. É preciso aprender usos e combinações, incorporar o gestual, diferenciar estados diversos (líquidos, cremosos, pontos), usar instrumentos.

Ante isso, o cozinhar e a própria cozinha era um espaço de contradições que não passava ao largo de uma lógica eminentemente de ordem prática. Como mecanismo de etnicidade tentava criar suas fronteiras, sem desfazer-se de seus laços regionais ou serem confundidos com outros grupos de estrangeiros, como os espanhóis. Mas ainda não tinham vínculos com uma imagem nacional que lutava por consolidar-se na terra natal.

Por outro lado, a ausência de referências mais claras em torno do trabalho feminino pode ter sido em decorrência de sua ligação ao universo doméstico. Atividades relacionadas à costura, como a confecção de sacos de café; produção de alimentos, doces, pães, massas, compotas; lavagem de roupas etc. eram atividades comuns entre muitas italianas e colaboravam para melhorar as condições da família ${ }^{40}$. Pelo fato de estarem circunscritas ao universo doméstico, sua visibilidade era muito menor, o que possivelmente fez com essa contribuição permanecesse em segundo plano.

A menção à produção de massas e pães nas casas, pelas mães e de maneira informal perpassa pelas narrativas de alguns interlocutores, embora não acentuem esse caráter étnico da produção,

$40 \quad$ Consultar Matos (2002). 
na verdade tendem a revelar a importância da família e suas relações internas, valorizando a união interna como um fator também preponderante para conquistar melhores posições sociais. As trajetórias individuais, grupo e sociedade e sua costura na memória ainda não são claramente entendidas ${ }^{41}$, mas é fato que a memória individual não é descolada de seu contexto social. Esse ponto é uma questão delicada, inclusive porque nos coloca diante de vários desdobramentos para pensar a presente pesquisa.

Nas memórias relatadas, as dificuldades que porventura se apresentassem jamais eram atribuídas ao preconceito local com os estrangeiros. Inclusive porque o trabalho entra como uma atribuição quase natural do imigrante italiano. É uma diferenciação da memória familiar e de vizinhança, mais desorganizada, ante uma memória mais organizada e pública, embora sem deixar de estabelecer vínculos entre $\mathrm{si}^{42}$.

$\mathrm{Na}$ verdade, esse tipo de memória seria uma forte expressão de negociações de identidade, em que a preservação do passado é feita pelo uso de percepções mais atuais, podendo mostrar a potencialidade de elementos ainda não utilizados. A cristalização desse conhecimento e sua transmissão constituem a herança social e remete a um caráter civilizador desse processo, já que forma (educa) e orienta (regula) sobre o que deve ser lembrado, expondo sua reflexividade em práticas comuns traduzidas em rituais ou em um mecanismo regulador da auto-imagem de um grupo. A comida claramente desempenha um papel de grande intervenção nesse processo.

Obviamente, a memória transmitida oralmente tem limitações, especialmente no sentido de armazenar as informações, de maneira que a escrita e o uso de objetos adquiriu importância central na transmissão do conhecimento, bem como a valorização da comida como forma de não perder vínculos com o passado. No caso dos primeiros imigrantes italianos, a reprodução de pratos de sua alimentação natal era um mecanismo que teria diversos objetivos: amenizar a ruptura que essa transição marcou na vida; aproximar imigrantes de um mesmo país, ainda sem uma noção nacional; bem como diferenciar-se de outros imigrantes latinos, como os espanhóis.

Nenhum desses aspectos emerge nas narrativas, com exceção das rivalidades entre italianos e espanhóis no Brás, firmemente calcadas em usos espaciais distintos do bairro e considerados pela sociedade local sob uma mesma categoria: imigrantes ou estrangeiros. A comida delineava claramente esses distintos pertencimentos, uma tentativa de não aceitar uma classificação externa ao grupo.

Essas dificuldades são amenizadas pelo reforço em torno do trabalho, cuja dedicação demarcou a situação presente tanto dos italianos como da cidade e projeta o futuro em movimentos de

\footnotetext{
$41 \quad$ Ver Kanstmeiner (2002).

42 Para uma discussão mais ampla, ver Assman (1995) sobre Halbwachs (1997) e também Domingues (1999).
} 
incorporação e descarte quase contínuo ${ }^{43}$. Esse aspecto ficou fortemente marcado nas falas do grupo entrevistado, já que sempre se manifestava uma forma de acentuar a posição atual e, inclusive, delimitar os caminhos do futuro em uma espécie de memória prospectiva ${ }^{44}$.

A comida como um meio de assentar identidades é de imediato acionada, talvez com maior vigor pelo fato dos anos de miséria vividos na Itália, privações que construíram um imaginário da nova terra como farta e abundante, embora não correspondesse exatamente ao que esses imigrantes pretendiam encontrar ou de fato encontraram. Entretanto, apesar dos obstáculos que se apresentavam o fato de dispor com alguma facilidade de farinha de trigo pode ter sido um fator para consolidar a noção de fartura como algo próprio da cozinha italiana praticada no Exterior.

O acesso a esse produto, algo que já representava um avanço nas condições deixadas na Itália teve um papel significativo na produção de ingredientes que seriam tomados como particulares desse grupo: pães, massas e pizzas. De certa maneira, ao chegar e não encontrar alimentos de apoio, a produção mesmo que informal e caseira de produtos reconhecidos pelos imigrantes foi um diferencial importante para consolidar a imagem de sua cozinha e adquirir certa independência do fornecimento local.

A coesão das narrativas está justamente nesse crescimento social e econômico por meio do trabalho, mas os silêncios e omissões reforçaram que houve preconceitos, lutas em um traçado pleno de percalços. A memória de acesso mais imediato, trabalhada junto a esses interlocutores, encontrou caminhos de se concretizar na cidade, tomando certos elementos como próprios de uma trajetória ascendente. Esses elementos inegavelmente serão incorporados às narrativas em uma seleção que nem sempre foi condizente com a realidade dos fatos históricos, mas tinha como objetivo reforçar uma dada ideia de realidade e reforçar identidades.

A memória nos defronta com um material ainda inexplorado, ressaltando que é preciso cautela para pensar como se entrelaça com a questão da identidade. Nesse sentido, a comida precisou ocupar um espaço diferente daquele que teria nos tempos da Itália, cuja reprodução se dava em um ambiente totalmente novo. O trânsito entre o conhecimento do cozinhar e a disponibilidade local que se confrontava com distintos repertórios regionais italianos criou um espaço de grande fertilidade para definir os contornos de uma cozinha italiana na capital paulista, com características próprias e instrumento de uma nova italianidade.

Esse processo em momento algum é referido, mesmo porque a memória de alguns interlocutores relativa à trajetória de seus estabelecimentos, muitas vezes não foi evocada de

$43 \quad$ Kansteiner (2002) sugere um caminho alternativo e instigante para analisar a memória do ponto de vista da difusão de informações, argumentando que seria preciso aprofundar pesquisas em torno da recepção de programas, documentários, filmes etc. relativos a processos históricos, em parte um projeto que iniciou em torno das imagens geradas sobre o holocausto.

44 Para esse aspecto, consultar Sutton (2001). 
modo linear, mas factual. Uns nasceram ouvindo os pais no restaurante, outros adquiriram o estabelecimento de outros italianos ou assumiram quando parentes não mais desejavam continuar o negócio. Outros vieram mais tarde e abriram seu próprio restaurante. Dessa maneira, a cozinha italiana anteriormente praticada que lhes serve de referência serviu para estabelecer a ligação com a nova condição, mas não traduz integralmente os sentimentos e os sentidos desse encontro.

O que é interessante pensar é que o cozinhar, apesar de toda a variedade de pratos regionais, foi uma forma amplamente manipulada para formar elos entre italianos, mas também maleável o bastante para que definisse os limites com outros grupos e a população local. Comer era uma oportunidade de conviver proximamente ou acentuar diferenças que hoje passam despercebidas nas memórias dos entrevistados.

Esse aspecto sem ser mencionado de modo direto, é evidenciado sob a evocação saudosa dos laços de solidariedade que existiam nos antigos bairros e hoje dificilmente resgatados na cidade que se tornou cosmopolita. Há um vácuo entre a vida dos bairros, grupos de italianos e a individualidade dos tempos atuais, percepção que se acentua também na forma de falar sobre a comida, vista como menos familiar e até certo ponto menos italiana à medida que esses laços vão perdendo força. Passa a ser uma comida globalizada, comercial, sem alma. As práticas dos primeiros italianos parecem ganhar força pelo fato que consolidavam a ideia de união e reconhecimento, cada vez menos presente na fartura de restaurantes contemporâneos.

Nem todos conviveram com os passeios na rua, as cadeiras nas calçadas ${ }^{45}$, o vinho de qualidade duvidosa servido sem muita atenção sobre tábuas de pinho, mas constituiu um imaginário em que os laços de amizade se mostram fortes, assim como a ideia do ser italiano, uma inviabilidade lógica em tempos de pouco reconhecimentos. É nesse ponto que se pode sugerir a ultrapassagem do individual para o coletivo, superando-se barreiras geradas pelos dialetos e origens.

Pelas narrativas dos interlocutores, entretanto, é difícil avaliar o impacto da chegada e o choque ao enfrentar a realidade local, embora a proximidade proporcionada pela concentração dos imigrantes em certos bairros possa ter sido uma forma de amenizar a disjunção vivida naquele momento. Se as diferenças regionais marcavam trajetórias entre esses italianos, elas também não deixaram de ser expostas nos bairros.

Encontrar um lugar mais cômodo na sociedade local tampouco foi fácil, filhos e netos de italianos ainda precisariam lidar com uma série de obstáculos que não foram dirimidos sem alguma resistência. Entretanto, os imaginários comuns, inclusive perceptíveis em várias obras que abordaram a imigração italiana e sua adaptação evidenciam o peso da imigração na construção de imagens da própria cidade de São Paulo ${ }^{46}$.

\footnotetext{
45 Ver Magnani (1998).

46 Esse espírito parece estar presente no trabalho de Cenni (2003) que enxerga a contribuição italiana desde uma perspectiva bastante atenuada de conflitos.
} 
As dificuldades enfrentadas pelos imigrantes na nova sociedade foram sendo apagadas no jogo de sombras e luzes. A crescente assimilação dos italianos não correspondeu à forma como sua cozinha caminhou ${ }^{47}$. Se eles conseguiram se adaptar graças ao seu esforço, trouxeram a comida como uma forma de marcar sua presença e reforçar sua italianidade. Foi graças a essa diferença que eles chegaram onde desejavam, ao menos no discurso e apesar de todas as dificuldades. A comida criou produtores e consumidores, mas não necessariamente um cenário homogêneo a não ser quando convém resgatar o passado quase épico do imigrante. No fundo, há um preconceito velado e não mencionado direcionado a outros grupos que compartilharam um começo duro como os imigrantes, mas não conquistaram a mesma posição, como os exescravos.

Esse ponto é crucial para manejar o material coletado, já que em boa medida há também a incorporação de uma espécie de roteiro em que as memórias são contadas para um público que precisa reforçar a imagem do italiano como o motor do progresso. A adaptação não foi fácil, mesmo porque durante anos houve um intenso ir e vir de italianos e parentes, mostrando o desejo de retornar à terra de origem. A própria trajetória de sua cozinha evidencia elementos contrários a essa afirmação, pois sempre tentou permanecer com seus elementos italianos, embora muitas vezes já com incorporações locais.

Muito material simplesmente ficará latente e outros fatos irão circular apenas por uma rede de comunicação informal, em geral, familiar ou de amizades. A função do "não-dito" é muitas vezes uma espera pela escuta ideal, nem sempre disponível, mas é verdade que a ênfase sobre o passado está anexada ao presente, deformando ou reformulando o tempo para construir interpretações do presente e do futuro. "O que está em jogo na memória é também o sentido de identidade individual e do grupo"48.

Nesse caso, a harmonia é uma referência longínqua para determinar posições sociais que não existiam de fato e acionar a etnicidade é na verdade um meio de enquadrar uma nova formação social, aspecto desse encontro ${ }^{49}$. Um momento em que se podem vislumbrar os entendimentos entre identidade, etnicidade e nacionalidade, agindo em sintonia ao longo da constituição do grupo.

A chegada de um novo grupo é sempre um momento de ajuste, tanto para seus membros como para a sociedade local. Na verdade, esses imigrantes precisavam lutar contra o estigma de serem apenas reposições de mão de obra escrava, embora brancos e europeus. E, apesar de

47 A assimilação dos imigrantes era uma questão de preocupação nacional, como assinalou Seyferth (1997) ao analisar a campanha de nacionalização do Vale do Itajaí, uma vez que os núcleos formados por alemães, poloneses e italianos eram percebidos como enquistes étnicos e a ideia de jus sanguinis que prevalecia entre esses imigrantes precisava ser apagada em função da unidade da pátria.

$48 \quad$ Pollack (1989:11).

49 Para essa discussão sob distintas perspectivas, consultar Oliveira (2000). 
"conviveram em harmonia" com os negros, não se viam como eles. As diferenças regionais tão marcadas no âmbito de sua terra natal acabavam solapadas pela percepção local que os definia como estrangeiros, imigrantes, italianos e normalmente de maneira pejorativa. Internamente tentavam resgatar suas raízes regionais, mas não ajudaria no sentido de criar uma imagem coesa ante o novo lugar.

$\mathrm{Na}$ realidade, existia um confronto de distintas lógicas classificatórias. Localmente, os imigrantes eram separados em função de sua aparência, evidentemente um traço discernível a olho nu e mencionado com frequência pelos memorialistas, ao lembrar que as descrições de roupas, aparência e linguagem eram bastante comuns. Essa lógica se nota também ao descrevêlos como europeus e brancos, embora imagem desfeita quando são classificados como sujos, arruaceiros, vestidos de maneira estranha quando tomam a cidade de assalto.

De qualquer forma, o eixo que parece estar presente é a aparência e assim estabelece quem é estrangeiro ou imigrante. Já para os italianos não é a aparência que parece orientar a lógica que os diferencia, pois buscam reforçar sua origem ante outros grupos, ressaltando seu viés étnico.

Dessa maneira, a retórica oficial inicialmente valorizava os imigrantes pelo seu caráter civilizador, mas diante do quadro que se desenhou, rapidamente o discurso se inverteu. Os imigrantes, tal como os ex-escravos, eram indolentes, revoltosos e em seguida foram instituídos mecanismos de controle variados: intervenções políticas, controles dos operários na indústria, intervenções médicas e sanitárias.

Rago (1985) cita uma observação de um inspetor sanitário, Dr. Evaristo da Veiga, em 1894, que ao visitar as habitações operárias de italianos falou o seguinte; "Basta [...] penetrar na habitação aglomerada de italianos para se depreender, desde logo, que o menor preceito de higiene e de moral, que é a base do edifício social, ali não existe". (Apud: 12). Ante isso, a ambiguidade que cerca a presença dos imigrantes é evidente. Se por um lado representavam o progresso ao "branquear" a população local, trouxeram também desconfiança pela maneira como se comportavam publicamente e se tornaram alvo de políticas moralizadoras.

Segundo Petrone (1990) a diferenciação entre o escravo e o colono assalariado foi amparada pelo mito de ascensão - quer fosse realidade ou não - ascensão que poderia ser social e/ou econômica, em contraste com as perspectivas dos ex-escravos. Em parte, esse imaginário da "melhora de vida" como ouvi de muitos interlocutores foi um mecanismo que atraiu milhares de imigrantes, mas também alimentou almas com esperança. A associação dos imigrantes, em especial italianos, com o progresso teve suas raízes nesse conflito em que a cidade saía de sua ligação com o mundo rural para se fincar na modernidade com suas indústrias.

Coube-lhes a missão de quebrar um paradigma fortemente arraigado entre as camadas favorecidas, sobretudo aquela beneficiada pelo cultivo do café, ainda imersas na dinâmica do trabalho escravo e suas relações perniciosas e a incipiente industrialização cuja base de 
mão de obra foi toda feita com imigrantes. E, ante esse quadro, desordem e atraso eram as características mais comuns que se atribuíam aos imigrantes, que não eram mais do que um joguete de governos e oligarquias ligadas ao café, mais tarde, dos industriais em busca de mão de obra relativamente barata e com a esperança de ter algum preparo em determinados ofícios.

A ausência de um vínculo interno que os diferenciasse acionou os mecanismos que determinariam seus traços diacríticos e rapidamente a comida encontrou um espaço de destaque. Superar diferenças regionais, ou amenizá-las, era uma estratégia de adaptação que se fez notar na cozinha e tinha um alvo certeiro, colocar nitidamente os limites do grupo ante outros estrangeiros e à população local. Diferentes tipos de massas, pizzas e pães de formatos variados começaram a conviver lado a lado e se tornaram referência de uma cozinha italiana local.

Desse modo, a comida era manipulada a fim de delimitar as fronteiras entre "nós" e os "outros", permitindo estabelecer uma incipiente percepção de italianidade, menos advinda da terra natal e mais fortalecida em função do encontro com a sociedade que os abrigou. $\mathrm{O}$ que parece estar em jogo é o afastamento de uma categoria mais genérica, imigrantes ou estrangeiros, para outra mais clara, a de italianos, embora no começo do século XX isso não representasse algo muito melhor que ser escravo.

Iluminar essas interações parece ser o passo necessário para compreender em que instâncias, embora sem esgotar, a comida delimitou as trocas e permitiu instituir meios de reconhecimento entre italianos tão díspares. Os vestígios bem acobertados por camadas de lembranças não poderiam ser vasculhados unicamente pelo viés doméstico, um universo de difícil acesso. Mas, silêncios são também formas de ocultar preconceitos e discriminações.

\section{A cozinha italiana na capital paulista: um modelo local em construção}

Falar de cozinha italiana no momento em que os primeiros imigrantes chegavam à capital paulista é praticamente impossível já que essa noção não estava nem mesmo consolidada entre eles mesmos. A Itália ainda lutava para formar sua identidade e nesse momento, começo do século XX, não existia ainda uma imagem de país que moldasse uma percepção homogênea de pertencimento e aquilo que poderia representar sua origem, não ao menos desde um ponto de vista de nação. Na verdade, o processo de unificação italiano começou tardiamente e seus efeitos só foram sentidos na cozinha a partir do fim século XIX, sem resultados consolidados quando milhares de italianos saíram de seu país ${ }^{50}$.

Nesse período, entre 1900 e 1920, os imigrantes que chegavam ao País e mais especificamente à cidade de São Paulo tinham em comum uma experiência de ruptura, mas ainda fortemente

$50 \quad$ Segundo Helstosky (Op.Cit.), em 1920 mais de 9 milhões de italianos residiam fora da Itália. 
marcada pelo sotaque regional, fato que acentuou a princípio distâncias culturais e sociais. $\mathrm{Na}$ verdade, o reconhecimento desses estrangeiros como italianos começou a ser construído quando se depararam com a sociedade local, e mais tarde pelo diálogo com a terra natal que se consolidava como nação.

Além disso, o próprio fluxo migratório não foi homogêneo como já mencionado anteriormente. Trento (1988) frisou que as origens e os destinos desses imigrantes apresentaram variáveis bastante acentuadas. Até 1902 predominaram italianos da região norte, especialmente do Vêneto e Friuli, tendo como principal destino os estados do sul do País, predominando pequenos agricultores interessados em ter seu pedaço de terra. É nesse momento que os Estados Unidos e a Argentina se sobrepõem ao Brasil e atraem milhares de imigrantes, verificando-se um declínio na entrada de estrangeiros no País.

Após 1902 e até meados dos anos 1920 ocorreu uma reversão das origens desses imigrantes, passando a predominar indivíduos das regiões meridionais da Itália que vinham destinados às lavouras de café, embora nem todos se dirigissem para o interior, muitos preferindo permanecer em São Paulo. Na realidade, se apresenta uma mudança na política de arregimentação, bem como de fatores de expulsão do país de origem $^{51}$.

Ante a diversidade que os próprios imigrantes traziam em função de suas origens, é preciso notar que isso se refletia na comida, cujos preparos, técnicas e ingredientes variavam bastante entre as regiões italianas pela própria inexistência de uma consciência nacional que permitisse compartilhar a comida de modo mais uniformizado ente os imigrantes. Alfredo DiCunto lembrou que "No meu tempo...no meu tempo... de italiano... eh, lá na Itália [...]havia muito regionalismo naquele tempo" e esse fato marcava fortemente a divisão de grupos de italianos em função da origem.

Na realidade, a partir do trabalho de Helstosky (2004) pode-se notar que os italianos que migraram tinham passado por momentos difíceis com relação à alimentação, uma vez que essa questão era profundamente problemática na Itália do começo do século XX. A situação vivida era de precariedade e a comida antes de ser uma prática de união, era uma prática que levantava conflitos, marcando distanciamentos e não semelhanças.

$51 \quad$ Para uma análise dessas características, consultar Alvim(1986). Embora os números sejam bastante incertos, Alvim (1986) levantou dados do Anuário Estatístico oferecido pelo Comissariado Generale dell'Emigrazione, revelando que a emigração de italianos para o Brasil, por região, entre 1876 e 1920 foi de: 365.710 provenientes do Vêneto, 166.080 da Campânia; 133.155 da Calábria; 105.973 da Lombardia; 93.020 do Abruzzi/Molise; 81.056 da Toscana; 59.877 da Emilia Romagna; 52.888 da Basilicata; 44.390 da Sicilia; 40.336 do Piemonte; 34.833 da Puglia; 25.074 do Marche; 15.982 do Lazio; 11.818 da Umbria; 9.328 da Ligúria e 6.113 da Sardenha. Para a questão da comida no interior de São Paulo, consultar Oliveira (2006). A autora ressaltou que para os vênetos a cidade não era um objetivo, ao contrário das preferências dos meridionais que sabiam das dificuldades de trabalhar no campo e tentavam permanecer na cidade 
Comer na Itália foi transformado em alvo de políticas públicas que tentavam reverter um quadro de fome quase permanente. Nesse caso, um dos itens que nunca poderiam faltar era o pão ${ }^{52}$. As massas já tinham considerável importância, mas ainda nada se comparadas ao pão ${ }^{53}$.

Na cidade de São Paulo, apesar do afastamento do centro da cidade e dos bairros elegantes, os bairros étnicos e operários estimularam novas sociabilidades. Ali também surgiram espaços de manifestação italiana como escolas, festas, clubes e associações com o intuito de aglutinar os oriundos, estimulando outra forma de circulação de pratos e comidas que seriam comuns, anos mais tarde, nas festas religiosas como Nossa Senhora de Achiropita, San Gennaro ou São Vito; no Bixiga, na Mooca e no Brás respectivamente.

Como já apontado anteriormente, a circulação de alimentos com viés étnico foi um meio de propulsionar certa independência dos italianos, mas também marcar seu gosto. Sesso Jr. (1995) descreveu a introdução da pizza por um napolitano, Lemos (1990) descreveu a rápida industrialização de produções caseiras por parte dos italianos. Penteado (2003) em suas memórias lembra os italianos que ofereciam diversos tipos de comida. "Patata assata ó furno!", que passavam no fim de tarde oferecendo batatas doces assadas e rapidamente acabavam com seu estoque. Também havia o pizzaiolo, "ó pizzaiolo, é cávora! Alitche e pomarola!" referindo-se ao italiano que vendia pizzas em uma enorme lata redonda cujo fundo tinha um pequeno braseiro. Além do pizzaiolo, outro italiano popular era o vendedor de castanhas que as vendia assadas, ao forno ou num fogareiro, trazidas em um carrinho de mão. Depois de assadas eram dispostas em um barbante e gritava "Ó castagnaro da festa! Castanha assata ó fruno!" 54 .

A comida encontra um lugar central na constituição de ideias em torno da nova experiência de vida, não só porque necessária, mas também por ser uma forma de evocar imagens e representações que confortam ante o novo, além de estabelecer algum tipo de vínculo entre imigrantes. A cozinha expressa sociabilidade, tanto na esfera doméstica como na pública e de alguma maneira acionou um inventário de receitas, ingredientes e rituais de consumo que passaram a circular na cidade e começaram a ser visíveis não só nos bairros de imigrantes, mas fora destes. Tal como observou van den Berghe (1984), esse modelo costuma emergir estimulado pela presença de um pluralismo cultural que naquele momento estava plenamente ativo na capital paulista.

52 Seria interessante pensar a importância do pão também pela sua ligação com a liturgia católica, religião praticada pela maioria dos imigrantes vindos da Itália, assunto que será tratado em outro momento.

53 Consultar Jacob (2003) sobre uma trajetória do pão e Camporesi (1996) sobre a doença do pão, ou "pão selvagem" provocada por fungos e que causavam delírios e alucinações.

54 Nas memórias descritas em Bosi (1996) um de seus interlocutores, Sr. Ariosto, descreve o italiano da carrocinha que vendia queijo e gritava "O fromaggio! Olha o fromaggio! (Apud: 155). O mesmo interlocutor fala do pão que sua mãe preparava e o ensinou a fazer, lembrando que ela fazia pagnottas que " $A$ gente comia com prazer". (Apud: 156). 
A cozinha então se presta a esse papel, mas tampouco deixa de lado a relação estabelecida com o passado. Nesse contexto fértil de encontros e desencontros na cidade de São Paulo, a cozinha italiana local estava em formação, bem como a noção de comunidade italiana. Reuniu condições para reproduzir receitas praticadas na Itália e graças ao acesso facilitado à farinha de trigo, artigo estimado entre os imigrantes ${ }^{55}$, foi possível constituir uma pequena produção étnica de pães, massas e pizzas que rapidamente serviu às famílias.

A farinha de trigo, junto com a água, era o multiplicador de uma cozinha simples e caseira, mas que a partir de poucos ingredientes produzia inúmeros resultados. Além disso, lançava mão de técnicas bastante difundidas e conhecidas que rapidamente foram recuperadas no novo cenário e apesar das diferenças regionais, delimitaram um conjunto bastante claro ante os locais.

Neste momento, a cozinha italiana não era nacional, mas ganhou essa percepção à medida que o espaço original se distanciou e precisou ser recriado em um novo contexto. Era também o elo que permitia estabelecer vínculos de proximidade com patrícios que até então, pouco tinham em comum além de abandonar sua terra em busca de oportunidades.

A presença italiana era um dado mencionado frequentemente como observou Trento $(1988)^{56}$ e não escapou ao olhar aguçado de Bruno (1954) que descreveu com intensidade passagens desse período, chamando a atenção para a comida:

\begin{abstract}
Mas é preciso registrar ainda uma outra feição da alimentação do morador de São Paulo a partir do último quartel do século passado: aquela influenciada diretamente pelo elemento italiano. Com a fixação de peninsulares em número considerável em São Paulo, desenvolveram-se indústrias alimentícias. E alguns temperos, a maneira de preparar certos alimentos e ainda a preferência por outros - característicos da cozinha italiana - se incorporaram definitivamente ao padrão alimentar da cidade. Não sem que houvesse incompreensões e resistência. Quando um italiano tentou introduzir em São Paulo o queijo gorgonzola - aproximadamente em 1888 - ocorreu um episódio curioso contado por Antonio Piccarolo: um inspetor de alfândega de Santos atirou o produto aos peixes, achando que seu cheiro característico era indício de putrefação. Mas aos poucos esse produto e outros produtos italianos - e sobretudo, a sua maneira de preparar alguns alimentos - tornaram-se familiares aos moradores da cidade de São Paulo. (1984, p.1112 e 1115)
\end{abstract}

A comida era um ponto que chamou a atenção de outro observador, Diegues:

O principal aspecto dessa influência italiana traduziu-se no novo tipo de casa construído em Santa Efigiênia, Vila Buarque e Liberdade ${ }^{57}$; e não somente no

\footnotetext{
55 Para uma discussão da importância da farinha de trigo entre italianos do começo do século XX, consultar Helstosky (2004).

56 PINTO, A. Moreira. A cidade de São Paulo em 1900 (impressões de viagem), Rio de Janeiro, 1990, p.9 Citado por Trento (1988). Observações semelhantes são relatadas por Lemos (2001).

57 Vale lembrar que os dois primeiros estão próximos ao Bom Retiro e a Liberdade à Bela Vista, na época com limites bem mais difusos.
} 
Brás, onde talvez menos sensível se fizesse observar a influência arquitetônica para se salientar mais em outros aspectos: nos restaurantes típicos, por exemplo. Restaurantes que começaram a influenciar a dieta do paulistano com o consumo de massas alimentícias e de vinho, que se vulgarizou, passando inclusive os hotéis a incluírem, em seus cardápios, minestra, rizzotto, spaghetti, pizza e outros tipos de alimentação de origem italiana. (Apud, Trento, 1988, p. 203)

Alguns imigrantes chegaram a questionar, com certa amargura, o fato de que a influência italiana foi apenas no mundo culinário e houve certo esquecimento da italianidade por parte dos descendentes, embora de alguma maneira resgatada pela comida:

\begin{abstract}
Os italianos, que aqui não conseguiram impor sua língua e nenhuma das grandes diretrizes políticas desses países, com certeza impuseram, após anos de sua laboriosa invasão, sua cozinha: e assumiram incontestavelmente o controle da gula desses povos fáceis. Por outro lado, há aqui milhões de compatriotas que, com certeza, comem mais do que italianissimamente. E os filhos desses italianos, os quais, por sua vez, esquecem a pátria de seus pais, nunca esquecem a cozinha de suas mães. (Op.cit. p.203)
\end{abstract}

A presença de comida italiana chamava a atenção dos observadores de maneira constante, o que levanta um ponto interessante. Se os memorialistas tendiam a concentrar suas observações aos bairros centrais, como sugeriu Santos (2003), a comida italiana aparentemente não estava circunscrita aos bairros étnicos, ou pelo menos, também circulava fora desses limites com alguma desenvoltura. E parece que isso se dava em alguns poucos hotéis da cidade e seus restaurantes, ao contrário da comida local. Bruno (1954) descreveu,

\footnotetext{
Jantando em 1905 em um restaurante paulistano observou o viajante português Sousa Pinto que lhe serviam minestra e risotto. 'É a Itália, escreveu ele, não há que ver, a Itália com arroz de açafrão e queijo ralado'. Por outro lado, entre os gêneros alimentícios vendidos à população em 1907, Gina Lombroso notou montanhas de caixas de tomate siciliano e massas napolitanas. (1954, p. 1115).
}

O que também pode ter acontecido é que muitos italianos pelo fato de circularem com mercadorias pela cidade acabassem ultrapassando os limites de suas regiões e estreitassem o contato com a população local. De qualquer forma, essa possibilidade contaria ainda com a produção doméstica de pães e massas que se amparou no incentivo do crescente comércio informal. Além disso, nas margens do centro, eram abertos pequenos comércios destinados à venda de produtos italianos, boa parte deles importados. Eram as cantinas, espécie de despensas, segundo Antonio Carlos Marino, proprietário do restaurante Carlino, em que se vendia um pouco de tudo, inclusive vinhos e queijos para o consumo no próprio local.

Apesar dos preconceitos, a Itália não se limitava aos bairros étnicos, mas nada indica que o comércio e o consumo de produtos italianos se estendessem de maneira intensiva em outros locais. 
Foi também nesse período que muitas fábricas de massas surgiram para atender a essa crescente demanda. Para atender às novas bocas, era necessário dispor de farinha de trigo, produto básico e muitos italianos se dedicaram à sua importação, bem como de outros gêneros alimentícios destinados aos patrícios. Ante essa oportunidade, Egidio Pinotti Gamba e os irmãos Puglisi Carbone, bem como Nicola Scarpa, Alessandro Siciliano e Rodolfo Crespi, além de Francesco Matarazzo se envolveram com a importação de alimentos ou sua fabricação. O caso do Conde Francesco Matarazzo é elucidativo dessa trajetória, pois começou suas atividades com a banha de porco; mais tarde entrou para o comércio de farinha de trigo que culminou com a fundação do primeiro grande moinho de trigo de Sao Paulo, fornecendo para inúmeras indústrias ${ }^{58}$.

É verdade também que o pão de farinha de trigo havia retornado à mesa do paulistano por volta de 1840, como apontou Bruno (1954), mas a intensificação de oferta desse produto foi em parte influência de italianos. Francesco Matarazzo era importador desde os anos 1890, trazendo farinha de trigo dos Estados Unidos e Canadá. Durante uma década não teve problema algum, mas quando se deflagrou o confronto entre Estados Unidos e Espanha, teve de buscar na Argentina o produto, decidindo investir na construção de um moinho que naquele momento seria uma grande novidade. Isso implicou em uma melhora considerável no abastecimento de farinha de trigo, bem como elevação da qualidade do produto que, em geral, chegava já azedo em função do tempo em que permanecia estocado nos navios ${ }^{59}$.

Além disso, antes de chegar a Santos, os poucos importadores e modestos moinhos ficavam somente no Rio de Janeiro, o que dificultava ainda mais obter um produto de boa qualidade. E fornecer farinha de trigo para um mercado crescente foi uma oportunidade vislumbrada por Francesco Matarazzo.

Na realidade, segundo Helstosky (2004), a imigração italiana teve um impacto profundo na reformulação de práticas alimentares, pois ao reproduzir itens de sua dieta da terra natal, o pão, as massas e a pizza foram instrumentos de uma etnicidade italiana além das fronteiras geográficas e com força maior que no próprio país. Graças aos imigrantes, principalmente massas e pizzas ganharam popularidade fora da Itália, com impacto evidente no consumo na própria Itália. De qualquer maneira, ao reproduzir pratos incomuns localmente, tentava-se delimitar quem eram "nós" e quem era os "outros"60.

$58 \quad$ Consultar Carone (2001). O autor chamou a atenção para o fato de que moinhos de trigo e pastifícios eram atividades complementares, uma vez que a fabricação de massas precisava de um fornecimento constante de farinha de trigo. Até 1910, São Paulo contava com seis moinhos de trigo, sendo apenas um de propriedade de um brasileiro. Os pastifícios também eram predominantemente de italianos. Para o perfil das indústrias paulistas, consultar também Trento (1988). A título de curiosidade, o pastifício de F. Casini e L. Dal Porto, fundado em 1878 , fabricava $500 \mathrm{~kg}$ de pasta por dia; o Romali, $3000 \mathrm{~kg}$ por dia e em seguida foram acompanhados por outros fabricantes, alguns contando com mais de 30 operários, como o F. Secchi.

59 Consultar Couto (2004 a e 2004 b).

60 Ver também Gabaccia (1998) a respeito da imigração italiana nos Estados Unidos em diferentes contextos e sua adaptação pela perspectiva das práticas alimentares. 
Surgiram pequenas padarias ao longo da rua onde hoje está o Memorial do Imigrante, mas também muitos vendedores ambulantes se dedicavam à tarefa de distribuir pão pela cidade. Era o pão de peito ${ }^{61}$, assim chamado pela sua casca dura que para ser quebrada precisava ser apoiada no peito.

Essa passagem é lembrada por Mariana Del Moro:

[...] Naturalmente o fornecimento de pão que eu me recordo era feito [...] o pão era feito no Bixiga por italianos, né? Aliás, esses até hum... não bem o que existe, porque agora industrializaram um pouco, eram feitos por senhoras, uma é...chamava-se Pipinella, que depois eu acho.. acredito que fosse ...Josefina o nome dela, é Josefina e a filha entregava o pão. Então, por exemplo, cada dois, três dias ela vinha com o cesto na cabeça né? Aquele pão de peito, aquele... aquele pão grande, que chama pão de peito. Porque você encostava no peito para cortar né? [...]

O pão continuou tendo um papel preponderante no imaginário italiano, em parte prolongado pela propaganda fascista e que repercutia entre italianos morando fora do País. O pão ganhou ainda importância no período entre as duas guerras, a tal ponto que fez que o Mussolini enunciasse com frequência um poema em louvor ao pão:

\footnotetext{
"Pão amado, Coração da Casa, Perfume na mesa Alegria do coração Honorável Pão, Glória dos campos Fragrância da terra Festa da vida" ${ }^{62}$.
}

Alguns anos mais tarde, em 1929, a Itália instituiu a Festa do Pão, uma ação em conjunto entre padeiros e membros dos partidos fascistas locais em que se distribuíam sanduíches e panfletos contendo informações sobre os valores nutricionais do pão. Era comum associar o pão integral ou pão feito em casa com uma dieta inadequada e monótona, sobretudo entre os moradores da Itália rural. Diante disso, é possível traçar um paralelo com o pão consumido pelos italianos, uma vez que muitos dos que vieram da Calábria e que apenas consumiam pão feito de farinha de castanhas - um produto de uso corriqueiro das famílias menos favorecidas - ao se depararem com a farinha de trigo, mesmo que de qualidade inferior, tenham preferido usá-la.

O pão branco, até fim do século XIX e início do século XX era um item caro e consumido apenas pelas classes mais favorecidas. Dessa forma era considerado de luxo, inclusive pelos imigrantes locais, uma vez que seu principal ingrediente era escasso e de difícil acesso à

$61 \quad$ Lemos (1990) e Cytrynowicz (2000).

62 Giuseppe Tassinari, Fascist Economy, pág. 106, Helstosky (Op.Cit.). 
população menos favorecida. Nesse sentido, o fato de poder consumir pão branco melhorava certos aspectos da vida miserável levada por muitos desses imigrantes. De alguma maneira, era reforçado o fato de que se vivia um momento de maior esperança, mesmo sendo um pão duro e com vistas a ser conservado por vários dias, não era o pão feito de castanhas catadas. Era um pão feito de uma farinha de trigo, cuja moagem se deu em uma máquina e não pela força animal ou dos braços, sugerindo que o pão branco era mais civilizado que outros tipos como integral ou de farinha de castanha. Há também a questão da brancura da farinha, como alguns interlocutores falaram ao selecionar os ingredientes de suas massas, chamando a atenção para esse aspecto ${ }^{63}$.

Tanto homens como mulheres colaboravam nesse processo, muitos italianos se transformaram em donos de padaria e muitas mulheres esticavam o orçamento familiar com a produção de pães e a venda nas ruas, normalmente uma tarefa que cabia aos filhos. Domenico Laurenti quando questionado sobre os motivos pelos quais eram tantos italianos donos de padaria, respondeu:

\begin{abstract}
Tinha muito italiano porque acharam que o serviço da padaria era bom, não? [...] Vinha muito patrício, e um patrício aprendeu com o outro [...] Pra... Na minha opinião [...] é porque um parente quando chegava de lá da minha terra ia trabalhar junto. Depois aprendia e "ponhava" padaria por conta dele. É por isso que tem muita padaria. [...] E não era só padaria, tinha muito pastifício de italiano. Que mais? Não me recordo...Cantina, cantina, cantina tem mais do que padaria.
\end{abstract}

O entrevistado resumiu a dinâmica dessa produção étnica, algum patrício conseguia se estabelecer e trazia novos companheiros que rapidamente aprendiam o ofício, em função da rede étnica de solidariedade que marcou esse primeiro momento. Quando conseguiam se manter, não hesitavam em ter seu próprio negócio e reproduzir o mesmo tipo de vínculos, muitas vezes utilizando uma distribuição de produtos também feita por patrícios, aproveitando a circulação de mercadorias comum daquele momento, de porta em porta. A sociabilidade não era apenas em termos de amizade, mas de socorro entre pessoas que compartilhavam uma situação menos prodigiosa.

A família de Alfredo DiCunto foi também exemplo dessa solidariedade. Seu pai Donato DiCunto, filho do segundo casamento de Costabile Carpinelli, abriu uma padaria na Rua Visconde de Parnaíba no fim do século XIX que foi deixada a cargo da família quando retornou para se casar, em 1905. Nunca mais voltou, embora seu irmão, Giuseppe, tenha ficado para cuidar dos negócios, que lentamente foram decaindo. A padaria ficou nas mãos de

$63 \quad$ Sobre a questão da cor, branco, seria interessante pensar desde a perspectiva discutida por Mintz (1985) em relação ao açúcar, uma vez que quanto mais branco, melhor seria sua qualidade. É curioso pensar que a farinha de castanha possui uma cor mais próxima do cinza ou marrom e, portanto, seria menos pura que uma farinha clara. Hoje os sentidos se inverteram, o pão branco é considerado menos saudável que um pão feito de castanhas ou outros produtos semelhantes. 
funcionários, depois de outros proprietários e chegou a fechar em 1929. Em 1933, Lorenzo, filho de Donato, acompanhado de sua mulher, Michelina, vieram para preparar o imóvel que iria abrigar novamente a padaria e em 1934 todos voltaram ao Brasil, Alfredo à época com 12 anos.

Essa trajetória não foi nada incomum entre os imigrantes, ressaltando que a ruptura não foi total e completa. Apesar de muitos não terem condições de voltar à Itália, mantinham comunicação com a parentela que havia permanecido, muitas vezes estimulando seus membros a vir. Esse diálogo teve impactos para a comunidade e para a forma como usaram a comida para fortalecer sua imagem.

Nesse sentido, outro ponto em comum eram as massas. Estas já pertenciam à alimentação dos italianos pelo menos desde 1371, como apontaram Serventi \& Sabban (2000), quando as autoridades da Sicilia regularam a venda de "macarrão branco de semolina e lasanha de semolina" e "macarrão de farinha e lasanha". A produção de massas estava presente em outras regiões do Mediterrâneo, como a Provença (França), bem como a região da Ligúria (norte da Itália e famosa pela cidade de Genova), que detinha certa reputação na produção de pastas, em geral, secas. A diferença entre os tipos de massas tinha impacto direto na comercialização desse produto, pois os fabricantes de massas secas poderiam atingir pontos de venda mais distantes, tarefa mais difícil para os que se dedicavam às massas frescas, cuja produção era diária e para uma clientela próxima e restrita.

De fato, a massa seca era importada da Itália logo no começo do século XX, mas não impediu o surgimento de inúmeras fabricações caseiras de massa fresca, inclusive porque nem todos os tipos de massas poderiam ser feitos em máquinas e os formatos variavam bastante conforme a região de proveniência, técnica fundamentalmente feminina, segundo Serventi e Sabban (Op.Cit.).

A máquina de extrusão utilizada para o preparo do espaguete surgiu no fim do século XVII, ao menos de maneira mais disseminada, e era utilizada para a fabricação dessa classe de massas. Pesada e grande, sua manipulação era fundamentalmente masculina, saindo de suas prensas os espaguetes, talharins e similares. Formatos diferenciados estavam a cargo das mulheres que acumulavam inúmeras técnicas para transformar a massa de farinha e água em formatos de peixes, borboletas, pequenas trouxas.

O sul da Itália rapidamente adquiriu superioridade na produção de massas secas em função de uma técnica desenvolvida pelos produtores locais que representava em fins do século XVIII uma grande novidade, a melhora do processo de secagem $^{64}$. Foi nesse momento que a cidade de Nápoles adquiriu fama como produtora de espaguetes e ficou reconhecida em outras regiões

64 A técnica descrita por Serventi \& Sabban (2000) consiste em três fases: incartamento (formação de uma pequena película sobre a massa após sair da prensa) rinvenimento (proteção da massa e disposição em um lugar frio para amaciar a película formada) e essicazione definitiva (secagem final). 
da Itália, além de ser a principal exportadora de massas para os países que absorveram grandes contingentes imigratórios que além do Brasil, consistiam nos Estados Unidos e Argentina ${ }^{65}$.

E Nápoles foi fortalecendo sua imagem de "devoradora de macarrão" que além de ter criado uma ampla oferta de massas, desenvolveu modos particulares de servi-las, especialmente o gosto pelo macarrão como molho de tomate, difundindo esse hábito a partir do século XIX para outras regiões da península itálica ${ }^{66}$. Como produtora de massas e molho de tomate a região ganhou destaque a partir do momento que passou a atender os patrícios emigrantes, estimulando a venda de produtos enlatados, massa seca, carnes secas e bebidas. A indústria Círio de tomates em lata e a Buitoni de massas secas prosperaram imensamente na virada do século XIX para o XX justamente em função do crescente mercado à disposição fora da Itália ${ }^{67}$. Até então, o que predominava na Itália eram as pequenas produções artesanais e a piccola bottega ou as pequenas vendas em que se vendia um pouco de tudo, reproduzidas à semelhança no contexto paulistano e cuja finalidade era fornecer produtos italianos a uma clientela já formada, os patrícios.

Não há dúvida que ao associar acesso a produtos, a reprodução de saberes do cozinhar e imigrantes aglutinados em determinados espaços abriram a possibilidade do florescimento da cozinha italiana ${ }^{68}$. É a adaptação do comer, uma prática cotidiana e necessária a um novo contexto, dialogando entre ideias e ações que se deparam ante novas materialidades, bem como a novas relações sociais, especialmente entre aqueles imigrantes que viviam no campo e cultivavam algum tipo de isolamento das pequenas comunidades.

Como se pode perceber, a cozinha é um espaço de trocas, se existem padrões alimentares que se mantêm anos a fio, são por meio de situações limite que mudanças surgirão afetando práticas do comer. Essas transformações podem ser atribuídas a vários fatores, mas é inegável que a situação de imigração é um poderoso estímulo ao encontro com pluralidade cultural e à mudança ${ }^{69}$, mesmo que não imediata.

65 Esse ponto foi abordado por Helstosky (2004) quando analisa o desenvolvimento industrial italiano graças ao consumo dos expatriados. Entre os produtos destinados ao exterior predominavam massas e latas de molho de tomate, apesar de que este só foi ser incorporado a partir do século XIX, antes disso, segundo observaram Capatti \& Montanari (1999) o tomate era um produto de consumo de classes bem desfavorecidas, sendo encontrado quase somente no sul da Itália.

66 Cappatti \& Montanari (1999) e Serventi \& Sabban (2000).

67 Consultar Helstosky (2004). A Cirio abriu sua indústria de tomate enlatado em 1856; Barilla de massa seca abriu sua planta em Parma em 1877; Buitoni já operava desde 1827 e expandiu nos anos 1880 na região de Arezzo; embora ainda fosse um movimento modesto com relação a outras fábricas de alimentos que surgiam pela Europa, conforme frisou a autora. Ver também Serventi \& Sabban (2000) e Cappatti \& Montanari (1999).

68 Aparentemente esse processo foi menos evidente nos Estados Unidos, segundo Gabaccia (Op.Cit.) uma vez que os imigrantes italianos se depararam com um intenso processo de industrialização e incorporaram muitos produtos enlatados e processados. Por outro lado, ela também afirma que nos bairros de imigrantes persistia um tipo de comércio que dependia menos do capital e mais da clientela étnica fiel, um fenômeno que também se observou na cidade de São Paulo.

69 Nesse sentido, o trabalho de Mintz (1985) elucida como o açúcar foi adquirindo distintos sentidos ao longo de seu uso, uma vez articulado a fatores que transcendem a disponibilidade e o consumo. 
A fabricação de massas foi um exemplo claro de adaptação, bem como o fabrico de pães. $O$ que foi necessário para adaptar não se sabe ao certo, pelo menos não fica claro nas memórias, mas sem dúvida foi uma resposta ao alcance das condições disponíveis. As técnicas de fabricação de massas ir-se-ão calcar nos conhecimentos já existentes e possivelmente repassálos a aprendizes, como frisou Alfredo DiCunto, um saber de ordem prática que se desdobrou em distintos níveis.

Comer é um ato repetitivo e cotidiano, mas é também onde se abrem as margens para novas interpretações. As diferenças são vistas de maneira desconfiada em um primeiro contato, mas à medida que suas raízes imbricam-se em solo local, parece que vão sendo domesticadas no sentido atribuído por Goody (1982). Nesse caso, o processo não é exatamente de sobreposição entre cozinhas de classes mais privilegiadas sobre menos favorecidas, mas um diálogo que revela distintas articulações envolvendo desde a produção, distribuição, preparo, consumo de produtos $^{70}$, e cuja complexidade não explica porque ao se deparar com grandes transformações sociais nem sempre a comida acompanha a dinâmica. Na verdade, menos do que incorporar elementos locais como forma de adaptação, os italianos tentavam resgatar uma comida que os fizesse se reconhecer entre si e perante a sociedade local.

A cozinha italiana possível de ser praticada teve de se amparar entre o saber prático, sobretudo das mammas, e o que estivesse ao alcance para reproduzi-la. Possivelmente não era nem mesmo uma cozinha italiana, nos moldes que hoje circula no imaginário, mas deixou suas marcas na cidade, como o apreço pelo pão ${ }^{71}$, assim como incorporou o que estava próximo, especialmente ingredientes. Assim, imigrantes tinham de se adaptar e sofriam com ações locais nesse sentido, concomitantemente eram bombardeados por diversas tentativas de manter uma suposta cultura italiana, enfatizando o uso da língua e se reunindo em associações e clubes.

O fato de encontrar proximidade promovida pela aglomeração em certas regiões da cidade teve sua influência na circulação de bens alimentícios, uma vez que essa rede ganhou força e reconhecimento. Trento (1988) lembrou que o comércio de ambulantes foi desde 1880 uma função praticada pelos italianos, desbancados somente quando entraram em cena os sírios ${ }^{72}$.

\footnotetext{
70 Sobre sistemas alimentares, considerar a instigante discussão de Contreras \& Arnaíz (2005) em que fazem um amplo retrospecto desse conceito.

71 Bruno (Op.Cit.).

72 Segundo Trento (1988), o reino do varejo era dos italianos, em 1882 de 166 lojas, passou-se a 8.700 em 1894 (em um total de 14.000) para baixar nos anos 1930 a 3.000. As camadas populares contavam ainda com a possibilidade de atuarem como barbeiros, sapateiros, alfaiates, cocheiros, cavadores, pedreiros, catadores, marmoristas, marceneiros, ferreiros, caldeireiros. Ainda, segundo o autor, dos quatrocentos lixeiros de São Paulo quase todos eram italianos. Inclusive, é possível fazer uma discriminação regional da distribuição dos afazeres: ambulantes, engraxates, carregadores, cocheiros eram praticamente todos meridionais; os cavadores eram piemonteses; os pequenos comerciantes de produtos alimentícios eram toscanos; os pequenos comerciantes de verduras eram meridionais; artesãos em geral toscanos ou do norte da Itália.
} 
Entre os interlocutores não foi raro ouvir menções de antepassados envolvidos com esse tipo de atividade. Antonio Carlos Marino contou sobre seu pai, açougueiro, que jovem começou com uma pequena carroça com a qual distribuía tripas e outros produtos que, na verdade, eram amplamente utilizados em receitas populares, bem como no preparo de embutidos. Essa era uma atividade comum entre estrangeiros e principalmente entre os

[...] espanhóis da Mooca que vendiam tripas, miúdos circulando com suas carroças pelas ruas do bairro oferecendo seus produtos à freguesia. As mulheres, principalmente porque naquele tempo não era comum trabalhar fora, iam até o vendedor e escolhiam os produtos.

Por outro lado, um interlocutor, Ângelo Luisi, apesar de mencionar que as mulheres "mandavam" na cozinha das cantinas, lembrou que algumas tarefas cabiam aos homens, em especial abater animais e limpá-los. No entanto, tanto homens e mulheres se envolviam no aproveitamento completo dessa carne, miúdos e sangue, sem perder uma gota sequer do animal. Esse aspecto estaria muito ligado à realidade em que viviam mergulhados em que não se desperdiçava comida, inclusive alguns pratos como o sanguinaccio era resultado desse pressuposto. Feito com o sangue do animal abatido era uma espécie de chouriço muito apreciado, ao menos nas lembranças, como um manjar, pois tinha um sentido muito especial, sabia-se que durante algum tempo a mesa seria farta pela presença da carne.

Esse conhecimento e sua reprodução foram perdendo sentido à medida que a comida foi ficando mais abundante e comer miúdos, denominação genérica das partes menos nobres do animal, se tornou um consumo para necessitados ${ }^{73}$. A manutenção ou descarte de alguns ingredientes, técnicas e pratos acompanham transformações mais amplas de ordem econômica, social, cultural.

Memórias, técnicas e acesso a ingredientes precisarão de negociar entre si para dar consistência a uma cozinha que seria um forte emblema da imigração italiana ao longo das décadas seguintes. Se por um lado a reprodução de saberes anteriores permite dar algum conforto à áspera situação experimentada, por outro lado abre um canal para a mudança e à incorporação de novos hábitos. Essa era a situação cotidiana desses imigrantes.

Nesse caso, a cozinha ainda articula ideias e regras que terão como principal finalidade classificar o que se ingere, enfrentando o dilema do onívoro ${ }^{74}$, ou seja, qual será a oscilação entre o novo e o duradouro. Mudanças elementares, como substituição de ingredientes são comuns, embora não alterem de imediato os padrões estruturais da cozinha. Outra forma de incorporar o novo é por meio da adição ou adoção de novos ingredientes, comuns em situações de contato

73 Hoje esse tipo de pratos adquiriu sentidos distintos, novamente valorizados, ao serem alojados na categoria de tradicionais ou que respeitam as raízes de um grupo e/ou local. Essa discussão será retomada oportunamente.

$74 \quad$ Fischler (1990). 
entre distintas etnias ou grupos. As mudanças mais profundas são aquelas que interferem na estrutura da cozinha, isto é, altera uma sequência de apresentação de pratos, condensa vários pratos em uma mesma refeição. A cozinha terá como responsabilidade operar essa lógica entre novidade e aversão, criando proximidade ou distância. As cantinas tiveram sua contribuição ao abrir sabores de casa para além da família.

Para não cair em uma situação de "gastro-anomia" ou desestruturação ${ }^{75}$, a comida tinha um papel importante. Fortalecer os vínculos sociais traria benefícios no sentido de orientar, enquadrar e formalizar o consumo alimentar; não era o momento de escolhas individuais, como se tornou o comer contemporâneo ${ }^{76}$; o grupo ainda exercia um papel importante sobre as decisões que recaíam menos na escolha individual e mais na regulamentação social, o que de alguma maneira conferia maior segurança.

A reprodução de pratos que falassem sobre si foi de fato um fenômeno deste primeiro encontro entre imigrantes italianos e população local, valendo-se de toda uma estrutura de produção e distribuição de cunho étnico. O avô de Afonso Roperto, herdeiro da Cantina Capuano no bairro do Bixiga, vendia hortaliças em carroça pelas redondezas da Bela Vista (Bixiga), apesar de ter um pequeno comércio, uma "quitanda", como frisou o entrevistado.

O entrevistado enfatizou que a rua e os italianos não eram necessariamente delicados, pois era um mundo violento, inclusive desavenças sem qualquer importância poderiam terminar em tragédia, como foi o caso de seu avô, morto por outro vendedor ambulante enciumado. Mas, apesar de ter uma quitanda, ele mesmo fazia as entregas de porta em porta das verduras e algumas semanas depois cobrava os valores devidos.

De qualquer maneira, esse tipo de comércio tinha uma clientela bastante certa, concentrada nos bairros étnicos. Nesse sentido, comer fora de casa tampouco era um fato comum, restaurantes eram raros, salvo aqueles localizados em hotéis que se destinavam a servir pessoas em trânsito. Nessas primeiras décadas da cidade, a grande exceção eram as confeitarias. Bruno (1954) descreveu um pouco da dinâmica das confeitarias:

\footnotetext{
As confeitarias de luxo, essas começaram a se localizar particularmente na rua Quinze de Novembro. No princípio do século atual (XX), porém, parece que o Largo do Rosário - aliás ponto final daquela rua - é que se tornou a localização preferida por elas. Ali, nas confeitarias, como se dizia no álbum de Jules Martin- reuniam-se os rapazes paulistanos. Confeitarias entre as quais se destacavam a Castelões, com suas três portas abertas até às dez horas da noite. As famílias caminhavam para lá - escreveu Cícero Marques evocando o 1900 paulistano - por volta das duas e meia às quatro da tarde, para tomarem sorvetes e comerem seus doces. Saíam depois porque às cinco era a hora das 'cocotes' de alto coturno, que então tomavam conta do local até a noite. As famílias abandonavam para outras confeitarias, a Fasoli, a Nagel na rua Quinze. Ou
}

\footnotetext{
$75 \quad$ Fischler (Op.Cit.).

76 Ver Collaço (2003). Para uma análise sobre o gosto, Warde (1997).
} 
então o Pinoni, pegado à Casa Baruel. Ou ainda a Brasserie e Progredior, esta na rua Quinze também. Na Progredior contou Cícero Marques que se reuniam famílias estrangeiras. E que de noite era também bastante movimentado o Café Guarani, procurado sobretudo pela boêmia: freqüentadores de espetáculos de teatro e café-concerto. (1954, p. 1157)

O que parece ser mais provável nesse momento é que o consumo de comida italiana fora dos limites dos bairros era uma eventualidade, pois ainda mantinha um caráter popular, de comida de rua, embora influenciasse o cardápio dos hotéis. Mas não se pode ignorar o fato de que as confeitarias eram populares, sobretudo entre as camadas favorecidas, e estas tinham enormes contingentes de imigrantes italianos trabalhando no preparo dos doces, bem como no atendimento. As descrições sugerem que a comida italiana desses primeiros tempos era praticada nos bairros e servida aos membros da comunidade, como deixou entrever Sesso Jr. $(1995)^{77}$, mas tinha algumas aberturas, como no caso das confeitarias.

Curiosamente, emerge um paradoxo, João Donato afirmou que eram os italianos abastados que frequentavam o lugar, "tinha frequentadores assíduos, os italianos apreciavam doces e muitos iam lá’, mas não parece ser isso, segundo alguns memorialistas deixaram entrever. Bruno (1954) em uma observação de José Agudo sobre a vida cotidiana em 1912, assim descreve o Café Guarani:

\begin{abstract}
Á porta, transbordando sobre o passeio, havia o habitual agrupamento de bacharéis em perspectiva, que ali costumam expor diariamente aos transeuntes pacatos o irrepreensível corte das calças vincadas e dos paletós cintados, a cromática mirabolância das gravatas e a extravagância morfológica dos chapéus. $(1954$, p.1157)
\end{abstract}

Não eram italianos, até talvez alguns pudessem frequentar o lugar, mas eram membros das camadas favorecidas que lotavam o estabelecimento. Cenni (2003) reforçou essa constatação quando descreveu a confeitaria Guarani, considerado o ponto mais elegante da cidade de São Paulo, para onde afluíam personalidades importantes daquele momento de diversas áreas: artes, política, banqueiros. Nada sobre imigrantes italianos.

Na verdade, o que diferenciava esses ambientes e, por extensão sua cozinha e frequentadores, era oposição entre uma comida considerada popular e étnica, e outra mais refinada, embora também de origem peninsular, mas de cunho mais profissional e associado ao açúcar. Essa ambivalência gerava a coexistência de distintos espaços, hierarquicamente dispostos. De um lado, a cozinha popular, cotidiana e étnica; de outro, pratos também italianos, mas ligados ao comemorativo, à exceção, às camadas favorecidas.

Na verdade, o uso do açúcar era um conhecimento muito difundido na Itália até pelo comércio realizado há tempos, inicialmente concentrado em Veneza e mais tarde atingindo outras regiões.

77 Algo semelhante foi descrito nas memórias de Armandinho do Bixiga, em Moreno (1996). 
Os doces para vários interlocutores é uma parte importante da cozinha italiana, embora pouco difundida no Brasil, tido como um lugar de pouco refinamento nessa área. Afonso Roperto disse que:

[...] os doces italianos não se difundiram muito, zepola, sfogliatella, (massinha frita coberta de mel), algumas ficaram, mas a sobremesa hoje na Itália é enorme, os doces brasileiros é que prevaleceram, bolo de mandioca, o gosto do brasileiro são coisas 'doces' e os italianos não gostam de doce.

O doce, categoria genérica para definir as preparações encontradas na confeitaria, circulou além dos limites étnicos, rapidamente descolados desse viés. Alfredo DiCunto contou que:

\begin{abstract}
Não havia tradição, costume do doce [...], houve um concentrado de doce que era... que era no centro, no Fasano, no Bar Viaduto que era no centro, quer dizer, tinha a Guarani que era no Brás [...] então nem chantilly se podia pensar porque não tinha gelo, nem geladeira, então os doces eram altamente perecíveis, não tem tradição de consumo, era muito difícil começar com doce $[\ldots]$
\end{abstract}

E na verdade, se a presença de italianos entre consumidores era rara, por trás das portas da cozinha eram esses braços que preparavam as receitas que agradavam os paladares mais refinados. Também os garçons eram em sua maioria imigrantes, denotando que os postos de trabalho dos estrangeiros eram considerados de menor prestígio social. ${ }^{78}$

Comparando a trajetória de distintos estabelecimentos, João Donato narrou o seguinte:

Tinha a Brasserie Paulista, da família Fasano, também servia doces, mas era no centro, em frente à Confeitaria Castelões que não tem nada a ver com a gente. $\mathrm{Na}$ verdade, o Castelões surgiu como um boteco, comum na época, e nem servia pizza. Oitenta anos atrás aqui (Brás) eram famílias de imigrantes italianos e espanhóis. Os pais do Sr. Ettore Siniscalchi, que fundou o Castelões, eram donos da Confeitaria Guarani. Eles tinham um prédio de dois andares ali na Avenida Rangel Pestana, moravam em cima e embaixo era a confeitaria. Dona Vitoria, mãe do Sr. Ettore, era quem cozinhava, Seu Dante tinha experiência em confeitaria e fazia doces que só ele sabia. Os filhos ajudavam no fim-desemana, os pais queriam que eles estudassem [...]. O lugar vivia cheio [...] Seu Ettore alugou o local, duas casas e abriu um tipo de 'boteco' e aqui ele tinha então um fogão, ele fazia frango alho e óleo, servia provolone, azeitona e vinhos importados.

Para descrever seu próprio caminho, João não se desfaz de pontos marcantes, quer do ponto de vista individual, quer do ponto de vista coletivo, entremeando sua história nesses distintos

78 Na fala coletada por Bosi (Op.Cit.) o Sr. Ariosto contou que foi garçom e que eram em sua maioria filhos de italianos. Os portugueses eram encaminhados para a cozinha nas tarefas mais rudimentares, como descascar batatas e fazer a limpeza. Ele se lembrou das dificuldades de obter o reconhecimento de direitos, o que aconteceu somente quando Getúlio chegou ao poder. 
planos. Entre as memórias de João sobre os pratos desse momento, é curioso notar que ele descreve detalhadamente os quitutes servidos no Café Guarani, mas fala pouco sobre os pratos de quando a Pizzaria Castelões abriu, em geral rústicos e jamais as iguarias como as servidas na confeitaria.

Esses confeiteiros introduziram novas técnicas e saberes, sem saber ao certo o quanto houve de mãos femininas nesse processo, já que João chamou a atenção para esse ponto ao comentar a participação de Dona Vitória, esposa de Dante e sabidamente quem comandava a cozinha do Café Guarani. Trouxeram receitas que não se conheciam: pannettone, pastiera di grano, sfogliatella, zêpola, cassata, spumoni, sorvetes ${ }^{79}$. Na parte de salgados tinham coxinha, empadinha, sanduíches e na Confeitaria Guarani era servida a famosa torta rústica, segundo João:

\begin{abstract}
[...] uma das mais pedidas preparada com massa podre, mortadela, presunto cru, ovo e mussarela, tinha salsinha bem fininha (não era triturada) e um pouco de cebolinha, levada ao forno. Uma delícia! A receita da torta era da Dona Vitoria, assim como todos salgados, coxinhas, empadinhas era ela quem preparava, os doces eram de Dante, mas acho que a pastiera também era dela [...] tinha sanguinaccio (embutido), muitos sorvetes, cassata, spumoni [...]
\end{abstract}

Eram comidas que não faziam parte do universo esmagador dos imigrantes, iguarias degustadas apenas em ocasiões especiais, pois em geral a comida seguia o mesmo padrão todo dia sem muitas variações em suas bases. Contudo, o açúcar e as receita de doces são também parte da cozinha italiana e não podem ser desvinculados desse conjunto e sua trajetória na cidade.

Esse aspecto é discutido por Capatti \& Montanari (1999) que notaram uma proliferação de receitas com base no açúcar em função do comércio promovido desde a Renascença pelos vênetos, criando um grande conhecimento em torno da utilização desse ingrediente. Para os autores, o uso do açúcar é um triunfo da cozinha italiana, que teve seu período de apogeu no Renascimento desenvolvendo amplamente a confeitaria. Referências ao sorvete existem desde o século XVI quando eram trazidas neves das montanhas para gelar frutas e bebidas, mas de fato conquistou um espaço diferenciado a partir dos métodos de refrigeração artificial desenvolvidos no século XIX ${ }^{80}$.

Permanece a dúvida quando ao processo em que esses doces foram introduzidos aos paladares paulistanos, pois o que realmente demandava uma técnica mais apurada eram os sorvetes e de

79 São doces, segundo outro interlocutor, típicos do sul da Itália e especificamente da região de Nápoles. Pedro Porta comentou que a pastiera di grano era um doce de Natal, mas acabou sendo feito cotidianamente, ao contrário da zêpola ou doce de São José, espécie de sonho feito de massa frita que só é encontrado no dia 19 de março, quando se comemora o santo. A sfogliatella é um doce em formato de concha recheado de ricota e frutas cristalizadas, era comum acrescentar licor de laranjeira. A cassata é um sorvete em forma retangular feito com frutas secas e às vezes coberto com chocolate. O spumoni é um doce gelado feito à base de ovos.

80 Para a discussão dos novos processos de conservação consultar Goody (1982) que fez uma vasta descrição dos avanços de conhecimentos em distintas áreas como química, biologia, física etc. para desenvolver métodos mais eficientes na preservação dos alimentos. 
fato já era bastante difundida na Itália nesse momento, em geral, preparado por confeiteiros homens.

Alfredo DiCunto lembrou das dificuldades de conseguir ingredientes, em especial a manteiga, "sempre de má qualidade, rançosa". Lembrou que a tradição dos doces é uma herança familiar, já que o pai de sua avó já era confeiteiro em Scalfari e muita coisa do que ele aprendeu foi com sua avó, tornando-se um exímio confeiteiro e cujo ofício repassou aos seus funcionários. Diante disso, é possível imaginar que as divisões de trabalho eram bem menos evidentes que nos tempos de hoje, já que se nota uma indefinição entre o tipo de aprendizado, a prática, e a legitimidade do conhecimento.

De qualquer modo, a categoria de sorvetes e doces encontrava uma posição diferenciada com relação ao pão, às massas e pizzas. Eram iguarias nas palavras de João Donato consumidas em ocasiões especiais entre os imigrantes ou destinadas aos paladares de classes privilegiadas. Essa distinção reaparece sempre nas memórias e nas descrições de preparos de certos pratos, pois raramente são mencionados os doces, mas com frequência a produção de massas. Em diversas narrativas há menção às mães produzindo massas. Alfredo DiCunto descreveu o ofício,

\footnotetext{
Minha mãe, então..., minha mãe só fazia, era só um tipo de talharim, do resto era massas, a massa seca vinha de uma... de uma região de Napoli onde que se dizia o único lugar que na ocasião [...] era o lugar onde tinha todo o pastifício de Itália. Diz que é por causa do sol de Napoli [...] então os pastifício era tudo naquela região. [...] hoje tem pastifício em toda a região da Itália [...] então naquele tempo só conhecíamos o macarrão seco e o talharim [...]
}

Anitta Concetta, por exemplo, ajudava sua mãe na fabricação de massas que não contava com máquinas, mas com a ajuda dos filhos, evidenciando outra forma de estabelecer vínculos familiares, diferentes de outros estabelecidos quando na confeitarias, embora muitas famílias trabalhassem unidas, como foi o caso da Confeitaria Guarani.

Neste ponto, o intercâmbio de saberes e fazeres pode ter ampliado o repertório da comida italiana $^{81}$, inclusive estimulado pelo trabalho doméstico, atividade em que muitas italianas se ocuparam ${ }^{82}$ e abrindo um novo caminho para aproximar sabores, embora por um vínculo amparado em posições bastante desiguais.

A cozinha doméstica amparada no conhecimento feminino e na produção artesanal e étnica de produtos levava aos imigrantes a continuidade de padrões exercidos na Itália, mas não necessariamente refratários às investidas locais, como o próprio Alfredo DiCunto contou sobre seu apreço pelo arroz e feijão, "sempre na mesa". Nesse sentido, os próprios doces como parte

81 Para a interlocução entre cidades e comida, consultar Capatti \& Montanari (1999), Van den Berghe (1984), Zukin (2004).

82 Para uma análise desse processo, consultar Matos (2002). Ver também Harzig (1997) sobre as empregadas de origem irlandesa que foram para os Estados Unidos. 
de um conjunto maior da cozinha italiana conquistaram a sociedade local, embora não ficassem circunscritos à representação de uma comida étnica. Era uma nova frente de interlocução entre Itália e habitantes locais.

Esse ponto remete novamente à ideia da alimentação como sistema ${ }^{83}$, isto é, quem produz o que, para quem, com que finalidade, transformando o alimento em algo reconhecidamente comestível. Esse encadeamento articula diferentes formas de conceber a cozinha como apropriada, ou não, classificações do que é popular e distinto, urbano e rural, regional e local, ideal (Itália) e real (São Paulo). Nesse caso, os doces e salgados servidos em confeitarias estariam no topo de uma hierarquia, como deixou entrever João Donato, distante da comida de "botequim" servida nos pequenos comércios de italianos, inclusive a incipiente Castelões de 1924.

É diante de uma situação de confronto que se abrem as margens para transformar uma cozinha que, naquele momento, não estava consolidada e precisava se assentar sobre bases para ser capaz de distinguir, mas também aproximar. O sentido do comer está relacionado com o lugar, com o social, com o cultural, mas inegavelmente novas hierarquias estavam em andamento sob a orientação de novas lógicas.

A produção do alimento (de onde vem, quem plantou, quem fabricou); como é distribuído (em lojas, no comércio de ambulantes); quem prepara, quem consome (como, quando, o que, com quem) terão de lidar com novos arranjos capazes de transmitir ideias sobre a nova experiência. A cozinha como espaço de trocas se desdobra na memória dos tempos da terra natal e enfrenta novas condições que trarão um novo repertório ao cozinhar ${ }^{84}$.

A disponibilidade de alguns produtos e a ausência de outros precisou contar então com a habilidade das cozinheiras que adaptaram seus conhecimentos à nova realidade. Mesmo com a dispersão desse saber gastronômico, houve a consolidação de um espaço culinário italiano, descartando e apropriando produtos e técnicas em um processo que foi lentamente criando uma linguagem comum entre imigrantes e também reconhecida entre a população local.

A produção artesanal de alimentos, a abertura das vendas e o cozinhar foram fundamentais para transformar a cozinha italiana em um instrumento de partilha entre imigrantes italianos e um meio de evocar lembranças de uma terra distante e para a qual o retorno ainda era um sonho acalentado. Por outro lado, também colocava limites entre os distintos grupos de imigrantes, bem como deixava clara suas preferências para uma população local reticente quanto à presença desses novos moradores.

Essa nova relação entre imigrantes e sociedade local - com evidentes desníveis de posição social - abriu um lugar para a transformação e delineou a partir desse momento uma relação

83 Para maiores detalhes, consultar Goody (1982), Fischler (1990). Ver também Contreras e Arnaíz (2005).

84 Inclusive, valeria a pena em outro momento comparar as diferentes trajetórias da cozinha italiana no Brasil, tomando as distintas regiões que absorveram imigrantes italianos, pois as diferenças parecem bastante acentuadas em função da forma como se acomodaram ao novo lar. 
simbiótica. Estava sendo produzida uma nova ordem e que se expressava na cozinha sob a tensão do cruzamento de distintos níveis. A cidade pouco sabia sobre as diferenças dessa diversidade, não tinha amplo repertório de alimentos e se viu defrontada por diversos ângulos com essa situação.

A construção de fronteiras foi um primeiro passo no sentido de consolidar a presença italiana e articular sentidos para a etnicidade e identidade, embora ainda não fosse o caso de pensar em nacionalidade, um elemento que seria acrescentado mais tarde. São justaposições de realidades que nem sempre aparecem nas narrativas dos entrevistados, mas que estiveram presentes na construção de mecanismos que fizeram que a comunidade italiana se transformasse em parte da história da capital paulista, ao fornecer um vasto material para sua retórica de sucesso, sobretudo, econômico ante outras cidades.

Talvez a comida não fosse nem mesmo inspirada integralmente em experiências anteriores, mas na representação do que deveria ser. Esse ponto pode explicar porque a valorização da fartura, que contou com a farinha de trigo como ajudante, transformada em um ícone dos primeiros tempos na cidade, servindo para os diferentes preparos e receitas que faziam parte do repertório do cozinhar vindo, sobretudo, com as mulheres.

Sob essa perspectiva, o momento em que chegaram os primeiros imigrantes italianos abriu oportunidades para a consolidação de um novo campo social em que emergem novos vínculos profissionais e sociais. Metaforicamente, a comida seguiu um caminho semelhante: ela não era um conjunto fixo ou consolidado de receitas, mas foi sendo moldada à medida que se articulavam distintos planos de uma nova vida.

O tempo sem dúvida concederá distintos significados, pois o que está sendo disputado é o controle das categorias que classificam e legitimam a situação. Quem produz a comida irá determinar o que é cozinha italiana, mas não existe descolada do grupo que a constituiu. A comida, portanto, materialmente maleável e sujeita a inúmeras possibilidades, se viu alvo de classificações que permitissem, metaforicamente, pensar a formação de um grupo e suas potencialidades. Seria o momento oportuno para a manifestação de uma cozinha italiana genuinamente local.

\section{A Cantina: modelo de sociabilidade e lugar de comida étnica e familiar}

São Paulo no início do século XX passava por um momento de transformação e nos ofereceu uma série de contradições em torno da presença dos imigrantes, sobretudo italianos. Estes eram sistematicamente alvo de comentários preconceituosos, olhares desconfiados, ações no sentido de moralizar seu cotidiano. Esse ambiente pouco favorável praticamente desapareceu de forma direta das memórias dos interlocutores, que tendem a descrever a trajetória da imigração como um exemplo a ser seguido. 
$\mathrm{Na}$ colagem desses fragmentos, a memória vai fazendo sua coleta em diversas fontes, resgatando fatos, descartando-os e traçando sua própria interpretação de um caminho que será iluminado por valores como perseverança, adaptabilidade, engenhosidade e luta. Tudo isso conquistado graças à família e ao apego ao trabalho, uma condição considerada praticamente como natural do imigrante, peças centrais recuperadas pelos caminhos das lembranças.

Entre os interlocutores a consolidação da cozinha italiana como um processo recente não parece ser um fato, mas algo dado, embora não se ignore as divergências entre distintas origens regionais, um aspecto relevante, especialmente quando há interesse em demarcar a linha de sucessão familiar. Ante isso, tampouco existiam muitos restaurantes, fato tanto observado pelos interlocutores como em distintas passagens de memorialistas, espantados com a falta de lugares "decentes" para um viajante conseguir efetuar uma refeição.

$\mathrm{Na}$ Itália, existiam algumas trattorias e osterias $^{85}$ que atendiam a viajantes e a alguns clientes, em geral de camadas menos prestigiadas. Além disso, alguns serviços de banquete também existiam, levantando a questão de que o cozinhar em restaurantes não era uma atividade constante e reconhecida, sendo a maioria das refeições feitas em casa e somente às vezes na rua, de maneira precária.

Essa realidade parecia ser estendida pela cidade de São Paulo. Falar em restaurante nesse momento seria também pressupor a existência de um lugar quase desconhecido do cenário paulistano, embora já delineassem uma ligação entre o que era servido, sua localização e seus consumidores ${ }^{86}$. Nos bairros étnicos, a comida das mammas feita para a família e estendida aos paisani foi inspiração para as futuras cantinas, bastante semelhantes aos estabelecimentos que existiam na Itália, em boa medida de caráter popular.

Eram espaços em que não se distinguiam de imediato o público e o privado e a família era um modelo central para garantir a sobrevivência, inclusive econômica, implicando distintas estratégias. As relações internas estabelecidas também diferem daquelas que hoje são vivenciadas, de modo que é preciso considerar de que forma o núcleo familiar estava constituído para compreender o funcionamento desse incipiente modelo de restaurante. A participação dos membros da família na atividade não era descartada, ao contrário, estimulada para conquistar melhores condições.

Nesse sentido, segundo Di Leonardo (1984) as matrizes que orientam as relações familiares e econômicas podem ser distinguidas em distintos modelos. A família pode ser uma unidade

85 Cappati \& Monatanari (Op. Cit.) analisaram o surgimento do comer fora na Itália, mostrando as diferenças entre osteria - um restaurante familiar de caráter modesto em que se pode comer em uma mesa coberta, normalmente com um pedaço de papel. A trattoria é um pequeno restaurante familiar que oferece um pouco mais de serviços e toalhas de tecido sobre a mesa e o restaurante, que oferece um serviço mais elaborado e uma cozinha mais cuidada. Ver também Helstosky (Op.Cit).

86 Para uma análise contemporânea do hábito de comer fora de casa, consultar Warde \& Martens (2000). Consultar também o trabalho de Finkelstein (1989) em torno do poder do espaço na orientação de dinâmicas entre os comensais e suas performances. Ver também a história do restaurante traçada por Spang (2000). 
de produção, em geral um tipo que está atrelado aos períodos pré-industriais e na qual todos, sem exceção, mulheres e crianças, são incorporados ao trabalho ${ }^{87}$. A família como produtora de renda é aquela que se molda à era industrial e, em geral, associada às classes trabalhadoras e na qual a mulher ocupa posições instáveis, ora saindo, ora entrando no mercado de trabalho. Um último tipo de constituição familiar diz respeito ao modelo contemporâneo em que a unidade é praticamente vista como consumidora de bens e serviços, afastando completamente as crianças do trabalho e eventualmente boa parcela das mulheres. Cada tipo de constituição familiar implica distintas práticas com relação ao trabalho e, neste caso, a percepção da experiência étnica e forma de conduzir os negócios.

Em geral, o modelo familiar que pareceu predominar nos primeiros tempos foi o primeiro descrito pela autora em que todos os membros estão integrados nas atividades econômicas ${ }^{88}$. Nesse período em especial, esposa, marido e filhos tinham atribuições específicas: mulheres encarregadas da casa, entre as tarefas principais estava o cozinhar. Os maridos podiam ter várias ocupações, mas atender os comensais era uma de suas obrigações, assim como os filhos tinham a responsabilidade de auxiliar em quaisquer tarefas que fossem necessárias, embora não pudessem deixar de lado os estudos, uma condição imposta com rigidez, pois isso significava a possibilidade de ascender social e economicamente, ao menos entre as famílias menos favorecidas.

É verdade que considerando o abandono gradativo dessas atividades pelas crianças e um novo olhar sobre o trabalho infantil, as menções sobre o assunto foram escassas, com exceção de João Donato. Ele falou a certa altura que ajudava seu pai "desde moleque", ou seja, a família estava sendo incorporada ao empreendimento, embora em momento algum ele tenha mencionado irmãos ou a mãe. A transmissão do negócio no caso da família de Donato foi feita pelo lado masculino, inclusive hoje quem cuida dos negócios junto com ele é seu filho Fabio, inclusive um fenômeno bastante comum observado entre outros proprietários de restaurantes e seus filhos.

Para João Donato, "naquele tempo as coisas eram muito diferentes", contando que esses lugares eram notoriamente frequentados por homens, normalmente das vizinhanças e muitas vezes trabalhando em uma mesma fábrica. Seu pai começou dessa forma e, João, acompanhou o processo. Contou que seu pai conseguiu trabalhar na época (entre os anos 1905 e 1915) na

87 Para uma análise mais ampla, consultar Trento (1988). Em 1920, mulheres e crianças representavam $40,8 \%$ da mão de obra industrial do País e 43,1\% em São Paulo. Em 1923, esse número avançou para 58\% da mão de obra eram mulheres e $38 \%$ crianças, especialmente na indústria têxtil; $43 \%$ e $30 \%$ na de vestuário; $30 \%$ e $34 \%$ na química e farmacêutica. As crianças representavam $51 \%$ dos empregados em atividades terciárias. $\mathrm{Na}$ verdade, os altos níveis de deserção das fazendas contribuíam para a absorção dessa reserva laboral pelas indústrias paulistas.

88 Adiante, veremos que ocorreram mudanças nos modelos familiares após os anos 1950 e novamente uma transformação nos anos 1990. 
Confeitaria Guarani graças às relações de parentesco e amizade, uma rede que "naquele tempo funcionava, embora o mérito fosse dele, pois não ligava de trabalhar".

Dante (pai de Ettore Siniscalchi) comprou um imóvel na Avenida Rangel Pestana, onde hoje é o Banco Bradesco, segundo João. Naquele prédio moravam e trabalhavam. A confeitaria era no térreo e nos andares superiores os apartamentos e era onde também residiam os avôs paternos de João, vizinhos da família de Dante. Cármino Donato, tio de Vicente e casado com uma filha de Dante e sua esposa, Dona Vitória, foi falar com eles para conseguir um trabalho extra para seu sobrinho. Assim, Vicente conseguiu um emprego de garçom nos fins-de-semana no Café Guarani ${ }^{89}$.

Rapidamente Vicente começou a ganhar mais na confeitaria do que na loja de sapatos onde trabalhava como vendedor. João chegou a pegar os últimos tempos da confeitaria, embora não tenha dito por que fechou, mas se lembra do imenso balcão de mármore que decorava o lugar, "dizem que era de Carrara", identificando um sinal da importância do estabelecimento, uma vez que esse acabamento era uma raridade naquela época, ao menos para os depauperados imigrantes. Em nada se assemelhavam às cantinas que se multiplicavam pelos bairros étnicos, como contou João:

\begin{abstract}
Brás era o reduto das cantinas, todas iniciaram no Brás. Agora só ficamos nós e o Bar do Chico, tinha outra conhecida na Rua do Hipódromo, a Cantina da Sílvia, essa era bem pertinho da linha do trem. Tinha outra, no Largo da Concórdia, Machiarolli, eram dois irmãos. Também tinha a Cantina do Lucas, precursor da sopa de tartaruga e eles começaram enfatizar que tinham rãs. Tinha outras aqui embaixo, uma que se chama Cantina do Marinheiro, mas não tem nada a ver com o que é hoje. Ela ficava embaixo do viaduto, nas imediações do Largo da Concórdia, na Capitão Faustino de Lima. Essa era muito boa, ele tinha frutos do mar que nunca vi igual. Era um espetáculo, espaguete com vôngole. Cantina da Zilda, na Avenida Celso Garcia quase esquina com a Bresser em frente ao Cine Rex [...] Também tinha muito boteco e muita padaria que funcionavam bem.
\end{abstract}

Com uma ambientação precária, esses espaços eram muitas vezes extensões da casa. Vendendo produtos para atender aos paisani, era comum dispor tábuas de pinho sobre barricas de vinho, algumas banquetas, onde os clientes se acomodavam e ficam horas jogando, conversando e bebendo. Além do vinho, era servido pão, azeite, azeitonas e queijos duros de coloração amarela

89 Baily (1999) faz uma interessante análise de Buenos Aires e Nova York e se torna flagrante a similaridade da cidade argentina com o exemplo paulista, embora não integralmente. Chama a atenção que tanto em Buenos Aires como em São Paulo essas redes informais de auxílio foram priorizadas e encontraram ampla ressonância pela boa recepção local, não que houvesse preconceito, mas á época Buenos Aires, assim como possivelmente São Paulo, se mostravam alternativas mais atraentes para o trabalho. Se os italianos encontravam posições desfavoráveis, existia uma ampla possibilidade de integrar as camadas médias em virtude do desenvolvimento econômico e da estrutura social encontrada em ambas as cidades que se dividia praticamente entre uma pequena elite e classes populares, ao contrário de Nova York onde os italianos foram rejeitados pela classe operária que já estava sendo formada naquele momento. 
(parmesão) e similares. Em algum momento passaram a ser oferecidas refeições simples, como sopas e massas, às vezes algum assado, mas sempre comida igual àquela feita em casa. Cardápio, conta e atendimento não eram características desses espaços, tudo funcionava na base da confiança.

Armandinho do Bixiga descreveu os armazéns que abriam em seu bairro, as futuras cantinas, falando que:

\begin{abstract}
Na minha opinião a palavra cantina está errada, porque antigamente, aqui no Bixiga, ninguém comia fora de casa, todo mundo comia em casa. Então cantina era um armazém (aqui no Bixiga tinha umas sete ou oito) com umas mesas onde de manhã o homem fazia caipirinha, pinga etc. [...]Às dez horas eles (o avô italiano e seus amigos) chegavam na cantina e aí ficavam bebendo. [...] O dono da cantina só vendia, queijo, azeitona e a bebida, que era a gasosa, o vinho italiano (não tinha vinho brasileiro) [...] (1996, pp. 31 e 33)
\end{abstract}

Era um ponto de encontro de homens e nada se fala a respeito da presença feminina, continuou o mesmo interlocutor a respeito da rotina dos italianos:

\footnotetext{
Meu avô saía todo dia com uma cestinha no braço, vendendo queijo na rua. Mas ele empesteava a casa porque ele ia no mercado e comprava os piores queijos do mercado. Olha que vida! Ele acordava às três da manhã e ia para o mercado (aquele mercadão) a pé. Chegava, comprava os queijos podres, voltava para casa e enfeitava os queijos, cortando os podres e dando aquela ajeitada. Ficavam uns queijos bonitos e ele saía vendendo às cinco da manhã. Ele batia de casa em casa. Às cinco já estava todo mundo acordado, não é como hoje. Naquele tempo o pessoal ia dormir cedo e acordava cedo. Às nove horas acabava o trabalho dele. Aí eles iam para uma cantina. (1996, p.31)
}

O seu avô sentava à mesa quando a comida estava pronta enquanto sua avó apenas observava. “O dono da cantina só vendia queijo, azeitona", pois muitos italianos já levavam o pão ou outro lanche preparado pela mulher. Em outros momentos, a esposa preparava uma sopa, minestra ou massa, pasta e todos comiam com a promessa de pagar alguma coisa quando recebessem o salário ou os pagamentos. O pai de Armandinho teve um bar no Bixiga que, segundo ele, era só frequentado por ladrões e sua mãe, por cozinhar bem, preparava para a clientela um cabrito ou macarrão. Era a continuidade de um modelo de trabalho em que a família consistia no núcleo produtivo, ainda fortemente apoiado na regulamentação do grupo.

As cantinas, então, surgiram em um contexto bastante específico em que a especialização dos bairros trouxe desdobramentos. Com o correr dos anos essa relação foi sendo dissipada, mas permaneceu latente na memória daqueles que de algum modo participaram do processo. $\mathrm{Na}$ realidade, não era nem mesmo uma refeição fora de casa, já que a comida feita e preparada sob padrões domésticos era também servida em um ambiente de proximidade. O que possivelmente foi transformador nesse momento foi o fato de ter um repertório de pratos de cunho doméstico 
circulando para além da família de modo muito mais intenso em função das dinâmicas urbanas propicias daquele momento. A cantina, de certa maneira, acelerou esse processo ao deixar a comida de casa mais evidente e foi ficando mais popular à medida que os espaços se tornavam pontos de encontro, conforme observou João Donato:

Bar do Chico, Cantina do Sílvio, Machiarelli, Cantina do Lucas, Cantina do Marinheiro, Cantina da Zilda, Cantina 1060, a Balila, e nós, porque além da pizza à noite eu também sirvo frango capão, fusilli, bracciola.[...] Tinha também o restaurante Garoto, era meio uma padaria e tinha um sanduíche de pernil que era maravilhoso. Em geral, as padarias tinham um pernil excelente no fim-de-semana $[\ldots]$

Pelo teor da fala do interlocutor, as cantinas pululavam no bairro com seu viés étnico e comida que representava proximidade. No começo do século XX, era o ponto de encontro após o turno das fábricas ou após a jornada de trabalho. João Donato mostrou algumas fotos para descrever o ambiente tal qual era, "Olha aqui, ainda tem umas fotos das velhas barricas de vinho, serviam de mesa", apontando para um espaço rústico e mais parecido com um bar.

Sesso Jr. (1995) descreveu em seu trabalho trajetórias semelhantes: não eram mais que tavernas e aos poucos foram adquirindo uma nova roupagem. Uma dessas cantinas foi descrita em detalhes pelo autor, pois se atribuiu ao seu dono, um napolitano chamado Cármino Corvino, ou melhor, Don Carmeniélo, a introdução da pizza. Foi um dos pontos de reunião mais populares da comunidade italiana, tendo como diferença o fato de trazer a pizza à mesa para ser consumida com talheres, ao contrário da pizza servida pelos vendedores das latas que circulavam pelas ruas, o que talvez tenha contribuído para torná-la popular, especialmente quando vendida nos jogos de futebol como lembrou João Donato ${ }^{90}$.

Don Carmeniélo também figura como exemplo do modelo analisado. Trabalhava junto da esposa e da filha mais velha, Maria Felícia e costumava entoar melodias napolitanas para os frequentadores de sua cantina. Feriados e domingos à tardinha a cantina vivia repleta de gente, com mesas e cadeiras colocadas na calçada. Quando Don Carmeniélo ficou doente, parte de sua clientela migrou para outros estabelecimentos, como a "Cantina do Giordano" e a "Cantina Bela Napoli”. Foi nesse momento que a Castelões cresceu e principalmente quando Ettore resolveu servir pizza, em meados dos anos 1930. João Donato acrescentou:

Seu Ettore era mais velho que meu pai e o convidou para vir trabalhar como garçom quando abriu o estabelecimento, desde que inaugurou está no mesmo endereço. [...] Ele tinha um fogão, ele fazia um frango alho e óleo. Tinha provolone, azeitona, vinhos, tudo importado [...] Rapidamente ficou pequeno

90 Bertonha (2005) faz uma rápida menção a essa questão em seu livro, ao comentar que a pizza era vendida nos estádios de São Paulo seguindo essa técnica: um ambulante carregando um latão com braseiro e servindo os pedaços aos torcedores. 
e eles abriram mais espaço, a cozinha foi para cima e só abriam à tardinha, enchia de gente. Lá pelos anos 1930 ou 1940, não sei, seu Ettore decidiu fazer pizza, ele mesmo. Aí a coisa deu certo.

Com o passar dos anos, Vicente ficou encarregado do restaurante e quando Ettore já mais velho, nos anos 1940, ofereceu 50\% da sociedade, Vicente logo comprou. No começo dos anos 1950 comprou o restante e Vicente ficou sozinho no restaurante.

A história do bairro do Brás contada e vivida por João Donato oferece uma boa distância dos distintos relatos históricos e testemunhais que foram coletados, até porque existe um profundo envolvimento emocional. O ranço irônico, a "avalanche italiana" mencionada por Monteiro Lobato, cede lugar a uma narrativa que busca coerência em laços de comunidade, espaços conhecidos, reconhecimento étnico. São visões muito distintas da presença dessa diversidade na cidade, embora não tenha sido dito nada sobre o acolhimento nesse momento, mas tenha sido reforçado o esforço de adaptação ao novo cenário. Tal não implica que essa presença não tenha de ficar difusa na paisagem paulistana; ao contrário, com o correr dos anos crescerá e se fará ouvir.

A experiência do Brás é também observada no bairro do Bixiga, sugerindo que a dinâmica era característica dos aglomerados étnicos. A Cantina Capuano é um exemplo ainda vivo dessa época, gerada a partir de uma sociabilidade assentada em vínculos étnicos e alguns pratos específicos: massas ao molho de tomate, cabrito assado e os já conhecidos azeites, provolone, azeitonas e vinho.

Era uma época em que ninguém comia fora de casa, salvo quem precisasse por estar em viagem. Na verdade, segundo Armandinho do Bixiga quem foi o pioneiro nesse quesito era um calabrês considerado "bravo" por todos, Francesco Capuano. Ele foi o único que serviu comida no bairro, mais tarde seguido por outros. Durante muitos anos a maioria do consumo fora de casa era de bebida e eminentemente masculino, denotando representações e classificações em torno do espaço e consumo diferentes daquelas observadas atualmente.

Capuano era exigente e começou com a ajuda de sua mulher, Filomena ou Filé, o pequeno lugar. Embora ambos cozinhassem, ela ficava encarregada de molhos, alguns assados e da fabricação de algumas massas. "Ninguém comia em cantina, o Capuano é que começou" (Apud:150). E confirma a versão de Ângelo Luisi, atual proprietário da cantina, pois não eram servidos mais que um ou dois pratos por dia, não tinha cardápio e o espaço era normalmente frequentado pelos homens. A fama de Capuano era de um homem intempestivo, às vezes brutal, não aceitava alguém recusar sua comida, quer fosse sugestão ou prato, o que poderia causar um descontrole no calabrês temido pela vizinhança.

Francesco era extremamente exigente e "mandava nos clientes", assim era sua fama pelo Bixiga. Fazia o cardápio e se o cliente não concordasse mandava para fora. A cantina começou 
em um estábulo, tinha umas mesas rústicas cujo pé era uma barrica de vinho e por cima uma tábua de pinho, cobertas com papel. Ele trabalhava com sua mulher na cozinha, quando chegavam os clientes ele ia para o salão atender e Filé se encarregava dos pratos. Se acabasse a comida, fechavam o restaurante e só voltavam no dia seguinte. "Era tão exigente que metia medo nos fornecedores, que nem o pessoal aí da fábrica de massas da Rua Santo Antonio, Salerno, o dono depois abriu um restaurante, Cilentano, já ouviu falar? ${ }^{91}$. Corpulento e rude, Capuano representava o italiano ao qual eram atribuídas características de violência e desordem, embora ao que parece pelas narrativas pouco se importasse, pois tinha sua clientela para alimentar.

Ângelo Luisi disse que ele era "um calabrês, de Cosenza, era um cabeça-dura" e o primeiro ponto era localizado na Rua São Domingos, do outro lado do viaduto. Segundo o mesmo entrevistado,

\footnotetext{
Ele colocou umas mesas na frente de casa, ele importava vinho, oferecia queijo parmesão em pedaços, sardella, todos vindos da Itália. O povo trazia o pão de casa e ficava por ali, jogando bisca para vem quer pagava a bebida.
}

A comida foi introduzida quando assumiram um novo estabelecimento, na Rua Major Diogo, por volta de 1907. Mas não existia cardápio como hoje, contou Ângelo, eram algumas poucas opções ditadas por Francesco em cada mesa e que só vendeu a cantina porque foi "infernizado" pela terceira mulher para voltar à Itália, em meados dos anos 1960. Anos mais tarde, já de volta ao Brasil, Francesco tentou recomprar a cantina, mas Ângelo não quis vendê-la e ele de raiva montou outra logo ao lado, criando um ambiente de disputa que ficou famoso no Bixiga dos anos 1970.

No entanto, Ângelo não seguiu o padrão de Capuano. Este se envolvia em todos os detalhes do restaurante, matava os cabritos, os assava, atendia a clientes, rabiscava a conta sobre a toalha de papel e não suportava ninguém que cortasse o macarrão com a faca, expulsando o herege aos berros do restaurante, atitude que não era rara no cotidiano do estabelecimento.

Tudo funcionava de forma diferente, o lugar dispunha de um campo de bocha, um jogo comum entre os italianos, pois as famílias só foram predominar anos mais tarde. Ângelo disse, "Eu e a patroa nos mudamos da Major Diogo para a Conselheiro Carrão, para ficar mais familiar", sugerindo que a clientela do restaurante não era exatamente das melhores. A maioria eram membros da comunidade que iam jogar e se estendiam por horas no lugar, muitas vezes saindo brigas pela bebedeira ${ }^{92}$.

$91 \quad$ Há uma passagem descrita pelo próprio dono das massas Salerno, Giovanni Mautone, em depoimento dado a Ana Stela de Sousa Pinto (1983). Ele contou que "um dia apareceu por lá um velho de 1.90m, mas a idade já tinha curvado ele. Botou as mãozonas no balcão sem nem cumprimentar e perguntou - tem fusilli que se apresente? Mostrei. Ele pegou a massa na mão e falou - mas isso é fusilli que se apresente? Era um desafio, e consegui fazer o fusilli, conquistei o dono de restaurante mais exigente da cidade, o Capuano.".(Apud:133).

92 A esse respeito, vale consultar as memórias de Armandinho do Bixiga, quando conta sobre a precária situação dos italianos que saíam dos bares com a "cara cheia", em Moreno (1996). 
Quando Ângelo comprou o restaurante do velho Capuano, sua mulher ficou um bom tempo aprendendo com ele as receitas e os segredos da cozinha para poder continuá-los em seu restaurante. Esse foi o combinado, pois Capuano estava preocupado em dar continuidade à fama de boa comida de seu estabelecimento.

Esse modelo de restaurante é aquele mais próximo denominado na Itália de osteria e foi o que predominou nessa época nos bairros étnicos. De características mais modestas, as mesas são cobertas com papel e o serviço é familiar, normalmente conduzido pelo dono ou algum de seus filhos ou parentes. A comida basicamente servida consistia em pão, embutidos, queijos e algum prato quente, em geral de origem caseira: massas, sopas variadas, tripas recheadas, língua e alguns assados. Esse tipo de restaurante é comumente frequentado pelas camadas menos favorecidas em busca de refeições fora de casa de caráter honesto.

$\mathrm{Na}$ Itália esse tipo de restaurante contava com um punhado de estabelecimentos e eram as conhecidos por servir o "molho da miséria", normalmente uma comida de cunho regional e doméstico. Essa semelhança é muito clara com as incipientes cantinas paulistas, um modelo que de alguma forma já estava registrado no repertório desses imigrantes e descortinou um meio de sobrevivência para muitas famílias. Custo modesto, ingredientes simples, sabores caseiros foram unidos para atender a um grupo em formação e ainda carente de emblemas.

A própria atitude de Francesco Capuano com relação aos clientes parece muito próxima daquela adotada na vida familiar. A impressão dada é que ele tentava empreender um ato educativo ao esperar que ninguém contestasse a comida servida, uma espécie de extensão da casa em que a comida deve ser respeitada porque foi feita pela mãe, demandou tempo e não pode ser desperdiçada.

Embora não houvesse o hábito de comer fora de casa nesse momento na capital paulista, esse evento começou a ser delineado nas cantinas, embora com caráter ainda muito marcado pelo viés doméstico. Era praticamente comer na casa de outra família, já que nem mesmo a conta era preciso pagar quando saísse, pois o costume de saldar as dívidas no dia do pagamento era usual.

De certa forma, sugere-se que além de uma forma de resgatar elementos condensados na memória da terra natal, a comida servida tinha certo papel controlador à medida que caracterizava ou reforçava representações em torno da cozinha italiana, especialmente importante para um grupo em que a identidade ainda transitava por limites indefinidos. $\mathrm{O}$ incipiente controle do grupo reforçava a caracterização de certos personagens, como Capuano, espécies de defensores da boa comida e legitimadores de uma cozinha ainda insegura.

A força dos vínculos comunitários estava muito presente entre vários interlocutores especialmente aqueles com raízes nos bairros que ficaram tradicionalmente associados aos italianos. Ângelo Luisi ao contar os passos da Cantina Capuano mostrou, mesmo sem chamar 
a atenção para o processo, como lentamente a cantina de cunho doméstico foi perdendo parte de seu espaço na cidade. Quando falou sobre a criação de um cardápio, "a concorrência estava $a i$ ', na verdade já era sinal de transformações.

O bairro era de "amigos, sabe, mas agora mudou, as coisas mudam né? [...] O bairro não é mais o mesmo". Esse desconsolo frente às mudanças é também visível na fala de João Donato, incomodado com as feições que o Brás tomou atualmente. "Era uma família, não é o cortiço que é hoje [...] não era a sujeira de hoje, a baianada, tudo começou com o metrô". Mas o fato é que essa baianada, sobretudo nos anos 1960, serão os personagens principais da cozinha no lugar das mulheres, conforme será analisado no próximo capítulo.

É importante notar que apesar de não existir ainda um grupo delineado, já estava em formação um controle capaz de definir o que era certo na cozinha e o que deveria ser consumido, como e quando. A comida era um instrumento de reconhecimento, até certo ponto de controle social, além de ter um caráter eminentemente prático, pois era o sustento de inúmeras famílias.

Nesses primeiros tempos, a cantina era fundamentalmente um espaço que dialogava com a linguagem do sul da Itália, pois foi a região que mais forneceu italianos para São Paulo, ao contrário do sul do Brasil, onde a maioria dos italianos eram do norte, em especial do Vêneto, apreciadores da polenta, quase sem nenhuma expressividade na capital paulista. Outro ponto que pode ter sido delimitador de diferentes caminhos é que os italianos que foram para o sul permaneceram nas regiões rurais, mais dispersos e a cozinha circulava em momentos especiais como festas religiosas, rituais de passagem ou na comercialização de produtos.

Como já dito anteriormente, o sul da Itália tinha uma larga tradição na produção de massas, sobretudo secas e foi um ofício que durante séculos esteve concentrado em mãos femininas, o que permite explicar em parte o conhecimento de longa data do manejo e fabrico de massas especialmente de modo artesanal e caseiro.

A força da comida neste momento não está descolada de sua origem regional, mas caminhava no sentido de aglutinar os imigrantes em um conjunto com alguma coesão que passava pela ideia de comunidade, muito presente entre os entrevistados que viveram no Brás e no Bixiga. Afonso Roperto, por exemplo, chamou a atenção quando lembrou que a comida da Calábria, de onde parte de sua família é originária, considerada mais "pesada", "forte", mas contava com a simpatia de outros imigrantes, especialmente quando a família de seu avô abriu um restaurante nas imediações da Rua Major Diogo e logo ficou conhecido nas redondezas.

Segundo o interlocutor, "a comida calabresa é forte, tem oliveira, uva e cabrito. As massas são feitas com molho apurado", é diferente de outras regiões da Itália, eles gostavam de

Fazer (comida) e comer na porta e talvez ao fazer isso tenha fomentado a cantina [...] a comida italiana criou uma identidade própria, o italiano não come sem pão e não fica sem pasta. O diferencial é no molho de tomate [...] Minha bisavó (da Calábria) usava muita pimenta, os molhos tinham carne e o 
manjericão, ao menos de onde ela veio, não era comum [...] Era tudo pesado, tudo grosso, tudo vermelho e tudo um pouco mais fechado [...] tudo isso era diferente de minha outra avó, napolitana. Era mais expansiva e tinha gosto pelos antepastos, o molho é diferente, ele é salteado, não fica curtindo horas na panela até ficar reduzido, não! [...] Se não tem ingredientes, faz substituições, foi assim [...] Na verdade era uma comida muito rústica, isso eles tinham em comum [...] Os próprios donos das cantinas começaram a se identificar, cantina era rotulada de 'popular', comida rústica, servida farta [...]

Afonso enumera uma série de aspectos discutidos até o momento; ele percebe as diferenças da cozinha italiana, sobretudo as técnicas regionais trazidas em cada lado da família e suas consequências na constituição de uma cozinha italiana local. Apesar de suas diferenças internas, a cozinha praticada naquele momento era rústica e familiar, possibilitando que fosse reconhecida no âmbito das cantinas e incorporasse um elemento de grande valor simbólico, a fartura. Ter acesso e poder desfrutar da comida é um aspecto importante da experiência dos italianos, uma vez que sua realidade nunca contou com abundância e estava relacionada à própria experiência em um novo país, a nova terra era dadivosa proporcionando alimento em profusão. Para Afonso, a Calábria oferecia pratos mais pesados, ao contrário de Nápoles; no entanto os conhecimentos se moldaram e criaram um tipo de cozinha em que prevaleceu a ideia de fartura e família, dissimulando diferenças de técnicas e uso de ingredientes.

A industrialização também contribuiu para uma melhora da distribuição e do acesso a itens considerados básicos pelos imigrantes. Fortaleceu a circulação de bens alimentícios, especialmente após a melhora do abastecimento de farinha de trigo proporcionado pelo moinho implantado por Francesco Matarazzo. Dessa forma, foi possível também contar com a opção do macarrão industrializado, afetando outras relações antes estabelecidas, pois se não de imediato os vendedores ambulantes e pequenas produções domésticas desapareceram, eles se especializaram naquelas massas ditas frescas, cuja produção é diária e menos extensa, em geral feita por mulheres.

A mecanização da produção de massas pode ter sido também uma forma de diferenciar o doméstico e o público. Transformar o macarrão em um produto industrializado, de fácil acesso ofereceria qualidades mais civilizadoras, a exemplo da sugestão de Pilcher (1998). A fábrica encarregada de oferecer algum produto que antes era produzido no âmbito doméstico, proporcionando um acesso mais fácil e uma qualidade menos instável, pode ter facilitado seu uso e incorporação como produto básico de uma cozinha italiana cotidiana. Esse ponto reflete o início da dissolução de um modelo artesanal de produção que inclusive afetará a estrutura familiar, pois se até meados dos anos 1920 predominava a família como núcleo produtivo, nos anos subsequentes foi crescente a inserção da família no trabalho fabril, deixando de ser o principal núcleo produtivo. 
Em parte, é preciso também adicionar o fato que a industrialização representava progresso e essa imagem está profundamente vinculada à imigração italiana. À medida que São Paulo transferia seu capital do mundo rural para a indústria, a ideia de avanço econômico se colava à ideia de consolidar a cidade como metrópole cosmopolita e os imigrantes, em alguma medida, conseguiam superar as dificuldades e estabelecer uma posição mais favorável. A ideia de progresso foi ainda reforçada pelo envolvimento de inúmeros italianos com as áreas culturais, especialmente a música e o teatro, uma vez que forneciam às camadas favorecidas várias alternativas para o incipiente lazer que se formava.

Em outras palavras, existia um desejo manifesto de europeizar a cidade, segundo Santos (2003), uma vez que representava um modelo de civilização, mesmo que idealizado e nem sempre confluente com a realidade vivida naquele momento ${ }^{93}$. Essas contradições eram visíveis na maneira como, por um lado, o imigrante representava em determinado nível o elo que desencadearia o progresso e, por outro, representava uma ameaça a sentimentos de brasilidade.

A vivacidade de alguns aspectos, a omissão de outros, reforça que foram estabelecidas acertos entre membros de redes de cooperação e ajuda, bem como com a sociedade local, além de não deixar de apontar o vínculo ainda vivo com a Itália. As distintas associações, embora pouco referidas, as sociedades de apoio mútuo, bem como eventos beneficentes e culturais eram meios também de formular identidades em uma feroz competição por trabalho e reconhecimento da sociedade local. Se na Itália eram vênetos, napolitanos, bareses essas distinções ainda persistem nos arranjos da capital paulista, mas tornavam-se italianos à medida que desejavam se contrastar com outros grupos estrangeiros e aos habitantes locais. Sua cozinha passava por um fenômeno quase semelhante, apoiada no uso da farinha de trigo.

As cantinas e a comida servida seriam decorrências dessas formas particulares de produção e distribuição que foram introduzidas pelos imigrantes. A cidade mudava em função dos novos arranjos, o centro era o lugar de circulação das camadas favorecidas e para onde iam as confeitarias. Os bairros étnicos eram o reduto das cantinas, inspiradas na comida feita em casa, onde a condução da refeição era praticamente a mesma daquela feita no mundo doméstico, apenas um pouco mais confortável do que uma comida de rua. Sem chefs de cozinha, sem uma alta cozinha (haute cuisine) ${ }^{94}$.

A confeitaria abriu um caminho para novos sabores que rapidamente foram incorporados pelas camadas favorecidas, ao contrário das massas e pizzas das cantinas populares. Na verdade,

93 Baily (1999) comentou algo similar com relação às políticas imigratórias argentinas que, na impossibilidade de trazer europeus de sua preferência - de países ao norte -, se contentaram em abrir suas portas aos italianos, já que os associavam ao progresso material e educação.

94 Para uma definição de haute cuisine, consultar Revel (1996) e Mennell (1996). Para uma interessante discussão entre estrutura social e alta cozinha, ver Goody (1982). 
além dos vendedores de rua, a cantina foi um tipo de comércio que tinha ainda vestígios de rua, mas incorporava novos elementos à refeição: mesas e cadeiras, um ambiente frequentado por conhecidos.

Sem dúvida, as mudanças transcorreriam na cozinha italiana, mas de imediato é necessário considerar que existe um repertório de receitas e estas não são transformadas de uma hora para outra, mesmo em uma situação de grande revolução nas relações sociais, como foi o caso da imigração. A preocupação em dar continuidade aos padrões conhecidos era até uma estratégia importante para amenizar os sobressaltos de uma experiência de grande dureza.

Seria um exagero afirmar que a cozinha conseguiu ser reproduzida em sua completude, mas sem dúvida que, entre os elementos mais acalentados, os derivados da farinha de trigo estavam entre os principais e em seguida se fizeram presentes. Não se trata somente de uma nostalgia, mas uma questão seguir normas que de alguma maneira mostravam uma origem em comum, não necessariamente regional, mas imigratória.

A própria origem familiar da cozinha praticada pelos imigrantes expõe sua necessidade de continuidade, pois é a partir dessas relações primárias que se estabelecem os vínculos com a comida, posteriormente com o grupo e delimita identidades, mesmo que ainda precárias. Não que seja de um determinismo irrefutável, mas a comida no contexto desses imigrantes tinha a força necessária para unir pessoas díspares, embora também deixasse exposta a diferença social.

$\mathrm{Na}$ realidade, os imigrantes italianos começavam a se ver como um grupo em função do próprio olhar que a sociedade lhes lançava, sua comida era diferente do que existia na cidade, assim como entre os próprios doces e comida étnica não se misturavam. Se as diferenças regionais ficaram menos evidentes em função dessas articulações, embora ressuscitadas em momentos especiais como festas ou nas sociedades de socorro mútuo, era em função de estabelecer um limite para não ser considerado apenas estrangeiro ou imigrante, e nesse sentido sua comida teve um amplo papel para começar a delinear o italiano. A casa e a família encontraram um lugar especial nas narrativas e serão centrais nas cantinas.

A cantina repassava parte dessa experiência, reunia uma incipiente comunidade italiana que apreciava consumir determinados pratos e a mulher era apenas uma coadjuvante, pois seu papel era de alimentar a família, inclusive, comunitária, pois essa é ideia que ressalta aos olhos de quem lê as narrativas. Esse esforço feminino recebeu pouca atenção, ao menos entre os entrevistados, salvo algumas exceções que mencionaram as atividades das mães e avós.

Giovanni Bruno lembrou que Dona Hebe, mulher de Enrico Lenci (que todos conheciam como Henrique) era a responsável pela fabricação das massas servidas no Gigetto. Ele ainda moço, a ajudava no preparo e secagem, além de transpor o azeite para garrafas ou latas menores, já que a importação era feita em grandes barricas, tarefas que eram realizadas após sua principal função, lavar pratos. Ele disse: 
O mundo estava sendo integrado em São Paulo, e as famílias trouxeram suas comidas [...] quer comida chique, tem; quer empada, tem; esfiha, espaguete [...] As mammas ficavam a noite inteira esperando que seu molho de tomate ficasse no ponto [...] E é verdade, a cantina não tem guardanapos, assim o Capuano é o verdadeiro! [...] São Paulo tinha o sabor de uma cozinha do sul da Itália [...] Os paulistas aperfeiçoaram a cozinha italiana, tanto que hoje você come uma cozinha de cantina, mas também uma cozinha de ervas, mais leve. [...] A imigração teve um papel nessa difusão. Tem povo da Itália inteira, com isso houve aperfeiçoamento [...] podemos dizer que temos uma culinária italiana característica de São Paulo, [...] toda a culinária italiana hoje se aclimatou e viveu as influências do local.

A cozinha italiana praticada nesse momento ainda não contava com a literatura especializada e a hierarquia gerada pela comensalidade étnica estava mais relacionada à questão do gênero e classe. Em geral, quem frequentava a cantina era o homem, à mulher cabia preparar a comida. A própria reprodução feminino/doméstico e masculino/público era uma dicotomia que não fazia muito sentido em um momento de em que a mulher não deixava de empreender suas tarefas, mas as estendia de maneira a conquistar novas formas de encontrar recursos para sustentar a família.

De certa forma, as cantinas deixavam claro que a comida italiana praticada era para ser consumida internamente, pois suas fronteiras se abriram mais tarde, especialmente pelas mãos das gerações seguintes. Mas não é uma questão de assimilação, fusão ou desaparecimento de certos elementos, a comida que nesse momento servia como um instrumento de reconhecimento tanto entre imigrantes como fora, não temia dissolver algo que ainda não existia. A lógica que orientava o preparo e o consumo era determinada por um grupo que tentava se reconhecer.

Nesse momento, tentava-se delimitar o que era o "nós" e de alguma maneira se rejeitava o local, vedado do espaço da cantina. Define escolhas e enfatiza a todo o momento relações que serão objetivamente expressas na comida para falar de casamentos, de imigrantes, de trabalho e da própria estrutura que caracteriza uma cozinha. Nada disso fica claro nas memórias, a não ser o fato de associar certas regiões da Itália às origens e ao tipo de comida, embora no presente essa diferenciação seja praticamente impossível, sobretudo nas cantinas.

Nas falas coletadas esse período poroso é pouco mencionado. A comida era um mecanismo ao alcance dos imigrantes para estabelecer uma posição na cidade e terem meios de se reconhecer a si mesmos. $\mathrm{O}$ uso da farinha de trigo foi emblemático para esses imigrantes porque se tratava de um produto escasso, e apreciado em sua terra natal e, ao estar mais acessível em seu novo lar, constroem-se novas imagens e são tomados como amarrações de uma experiência próxima. A disponibilidade de um ingrediente tido como um dos principais sentidos da alimentação italiana daquele momento possibilitou enxergar a nova realidade com menos desconfiança e tecer um reconhecimento em meio a tantas diferenças. Pão, massas e pizzas serão emblemas de uma trajetória que, anos mais tarde, serão centrais para a cidade, mas também terão estreito diálogo com a Itália. 
A cozinha étnica com todas suas fragilidades é no fundo uma resposta prática ${ }^{95}$. Ao surgir em um novo contexto, a cozinha italiana acionou uma razão instrumental que definiu novos parâmetros para a família, para o trabalho, para o futuro. A cozinha caseira mostrou um meio de vida e um instrumento étnico, comercializada no espaço da casa, mas com caráter público. Restaurantes e produção de pães e massas em casa foram maneiras de encontrar caminhos para garantir o sustento, em atividades que requisitavam pouca ou nenhuma instrução e se aproveitavam de uma clientela fiel.

As cantinas tiveram um papel social importante, pois abriram a oportunidade de estreitar laços entre distintos membros de um grupo que procuravam uma coesão para enfrentar uma sociedade que os excluía e os colocava à margem. Por outro aspecto, reproduziam na comida os laços sociais que se formavam e contribuíam para consolidar uma comida étnica.

A porta entreaberta oferece as margens flexíveis para consolidar um novo comer que não abandona as forças antagônicas que permeiam a imigração, especialmente ao revelar que nem todos os italianos poderiam acessar os sabores de sua cozinha, como no caso dos doces. Certas receitas teriam maior sentido de serem preservadas que outras, especialmente entre uma população com dificuldades de ler e escrever. Certos pratos evocam a terra natal, mas também definem as novas relações entre imigrantes. Nesse encontro o que estava em cena era uma negociação entre as potencialidades locais e a reiteração de um aprendizado anterior na busca de uma identidade.

A comensalidade não era nem mesmo um hábito comum, como chamou a atenção Helstosky (2004) ao descrever os hábitos alimentares na Itália do começo do século XX. $\mathrm{Na}$ verdade, a reunião em torno da mesa foi um processo observado fora do País e ente os imigrantes que valorizavam esse encontro a partir de um reconhecimento que foi deslocado do eixo do lugar, de suas origens, para o eixo da experiência. A comida ante isso foi renovada simbolicamente como instrumento étnico e exposta publicamente, reforçando seu cunho aglutinador.

Cozinhar neste novo momento dizia respeito aos reclamos do estômago, contudo não se desligaram das imagens nostálgicas da terra natal, de maneira que definiram um ritmo próprio. Os sabores poderiam evocar lembranças e sentimentos saudosistas, muitas vezes poderiam ser colocados de maneira festiva para frisar um ponto em especial, mas sem dúvida é no cotidiano que se observam as maiores transformações, pois é onde se cruzam reiteradamente distintas camadas que compõem o cozinhar e o comer. A comida é um bom meio para pensar como os grupos agem socialmente, no entanto nem todos se valem desse instrumento para definir ou reafirmar identidades ${ }^{96}$. Dessa maneira, a ancestralidade e o habitus permeiam as comunidades

\footnotetext{
$95 \quad$ Van den Berghe (1984).

96 Ver Brown \& Mussel (1984).
} 
de imigrantes, mas na cidade de São Paulo nem todas fizeram sua comida figurar, mesmo quando eram representativas, como os portugueses ${ }^{97}$.

Era um momento em que se selecionavam alguns elementos para falar sobre o país que ficou para trás e encontrar meios de criar um diálogo próprio com a sociedade que estranha e é estranha. Os desdobramentos serão em distintas temporalidades e fazendo uso de espaços que terão como objetivo constituir uma identidade e desenhar uma performance.

Diante desse panorama emergiu o primeiro modelo de restaurante: aquele que abriga um tipo de sociabilidade de cunho predominantemente étnico, público e para muitos habitantes da cidade alheios a esse ritmo quase como uma forma promíscua de convívio, já que se estendia ao estabelecimento o mesmo tipo de proximidade coletiva dos cortiços. Os limites pouco claros entre vida doméstica, lazer, trabalho e espaço público eram considerados pelo governo como um problema da população pobre, apontado à época como uma área de intervenção, especialmente de ordem higienista e que deixava sobressair um caráter moralista e intervencionista ${ }^{98}$.

A italianidade nem mesmo poderia ser definida nesse momento, mas era um processo em plena construção em que todos colocavam um pouco de si quer fossem calabreses, bareses, napolitanos etc. em uma situação de instabilidade onde residem potencialidades criativas. O espaço público será então nosso palco privilegiado, embora a memória tenha sua própria cadência ao não manifestar interesse por alguns tópicos. As ausências já descritas sugerem que os imigrantes italianos naquele momento precisavam de algo que iluminasse sua sobrevivência árdua. E a comida teve sua colaboração.

97 Uma questão que pode ser explorada em outro momento é a própria consciência de "comunidade".

98 Algo muito similar foi apontado por Levenstein (2003 a ) quando diversos programas de intervenção promovidos por órgãos públicos visaram a alterar a dieta dos imigrantes, especialmente os italianos, dado seu caráter pouco nutritivo. 
Capítulo 2: Imigrantes italianos e novos italianos: a disputa pela legitimidade na cozinha

\section{Cozinha italiana: de imigrantes a italianos}

Ao longo do trabalho foi interessante notar que a maioria dos interlocutores eram homens, filhos de imigrantes que tinham vindo no início do processo ou nos anos 1950 e viviam a angústia de ainda não estarem totalmente incorporados à sociedade local. Anteriormente, o emblema imigrante estava muito ligado à questão de etnia e classe em que a falta de prestígio predominou ao longo da vida da maioria desses estrangeiros. Com a prosperidade de alguns paisani e a vinda de inúmeros imigrantes italianos oriundos do pós-guerra, a relação entre classe e etnia adquiriu novos contornos, apesar de que os sonhos de "vencer" continuassem acalentados.

Para muitos também foi o começo da vida produtiva, de esperança em constituir um bom patrimônio, deixar a família bem de vida, mesmo que isso tivesse que ser feito contando com a ajuda de todos seus membros e o tipo de participação oscilasse bastante. Da articulação entre família e trabalho dependia a percepção de melhorar de vida. Muitos dos proprietários de restaurantes entrevistados lembraram que seus negócios começaram modestos e foram conquistando degraus da escala social, resultado ao qual não teriam chegado se não fosse a união dos membros familiares em torno desse objetivo. Entretanto, falar em sucesso é algo bastante relativo, mesmo porque depende das expectativas cultivadas pelo interlocutor, a trajetória de sua família, sua idade e a posição atual que ocupa.

É fato inegável que ao trabalhar com as memórias dos proprietários de restaurantes alguns impasses se acumulassem, especialmente ao perceber que as narrativas falam de um passado quase sempre imaginado e em constante diálogo com o presente, criando interpretações povoadas de elementos atuais, bem como selecionando ou descartando parte do imenso repertório disponível.

A memória, como já foi possível acompanhar ao longo da primeira parte oferece-nos um caráter sempre incompleto, embora seja uma prática de forte cunho instrumental para definir identidades. Nesse sentido, as narrativas analisadas foram bem claras ao realçar a importância do italiano para São Paulo, mas nem sempre deixavam explícitos os obstáculos enfrentados quando tentavam se inserir na sociedade local. Tampouco faziam referências diretas ao trabalho feminino na cozinha, a não ser de casa, mas que sem dúvida contribuiu para a consolidação da cozinha italiana pública, especialmente a das cantinas.

A decomposição das memórias mostrou que a origem é um elemento valorizado nesse repertório, mas não foi um elemento de unificação, embora à primeira vista fossem todos classificados na categoria imigrantes, especialmente pela língua, aparência e comportamento 
frente à sociedade local. O trabalho é uma referência também muito presente e delimita uma diferença com relação a outros grupos instalados na cidade. Na realidade, os descendentes entrevistados enxergam a imigração italiana como o ponto de inflexão para o início do progresso econômico da cidade e serviu como paliativo diante do fato de ter saído da terra natal. É curioso notar que não era um fato narrado com percepções claras, as incertezas da nova vida, a amargura de sair de seu país, bem como a desconfiança de quem ficou, foram elementos relevantes na construção de um imaginário positivo desse fenômeno.

Nesse sentido, os anos entre as duas guerras foram o início de uma ainda tímida ascensão social e diluição do caráter de "cidade italiana", inclusive porque nesse período o fluxo de entrada de imigrantes decresceu enormemente ${ }^{99}$. Ainda existiam muitos vendedores ambulantes ${ }^{100} \mathrm{e}$ se formava uma vasta classe operária, mais à vontade na paisagem urbana paulistana e, ante isso, muitos dos pontos de encontro desses italianos que, em boa medida eram estimulados pelo governo italiano como difusores da cultura italiana, perderam interesse dos descendentes. Nesse sentido, as sociedades de socorro, escolas de língua italiana, assim como programas de rádio e jornais ficavam cada vez mais destinados aos imigrantes da velha guarda.

Era o momento em que as segundas gerações já se adaptavam ao ambiente local e muitas vezes chegavam a esconder parte de suas origens e embora alvos de políticas fascistas com intuito de recuperar a cultura italiana ${ }^{101}$. Nesse sentido, "ser italiano" ainda não consistia em uma imagem coesa, já que os fragmentos regionais ainda persistiam, especialmente entre as gerações mais velhas, ressaltando um caráter belicoso de distintos grupos.

$\mathrm{O}$ esforço para consolidar uma cultura italiana entre os filhos dos primeiros imigrantes ficou evidente justamente a partir da observação desse crescente afastamento das novas gerações com ações pulverizadas no sentido de ressaltar o pertencimento italiano. Contudo não é um processo fácil de ser analisado, mesmo porque se houve uma recuperação da cultura entre os descendentes ao longo do período entre guerras, quando se deu a eclosão da $2^{\text {a }}$ Guerra, as expressões de italianidade foram eliminadas da esfera pública e concentradas no universo doméstico e da família.

Coincidia também com um momento em que a Itália pregava austeridade em função das dificuldades que passou a enfrentar, especialmente após invasão da Etiópia. Era uma propaganda voltada às mulheres e cujo controle deveria ser na cozinha, enfatizando a produção doméstica como o remédio para o desperdício. Esse processo trouxe a reboque uma revitalização da história da cozinha italiana, em parte como resposta a uma crescente nacionalização culinária que se iniciava nesse período e consolidação não só interna, mas externa.

$99 \quad$ Consultar Carelli (1985).

100 Segundo Trento (1988) em meados dos anos 1930, os números de italianos no comércio em todo o estado de São Paulo eram de 20 mil atuando como vendedores ambulantes, 65 mil no varejo e 5 mil no atacado.

101 Ver Cesco Tomaselli citado em Trento (Op.cit.: 288). 
A estratégia perpassou todo o governo Mussolini, cujo objetivo era produzir uma Itália culturalmente unificada. Mas não se contentava em atingir os peninsulares, a grande ambição era incorporar também o enorme contingente de imigrantes italianos morando fora do País, assim como seus filhos e netos. Inegavelmente que essa política teve algumas repercussões localmente, pois se o diálogo entre Brasil e Itália era morno entre governos, o mesmo não pode ser dito das relações entre imigrantes e seus parentes que mantinham contato permanente e constante.

$\mathrm{Na}$ Itália, o governo fascista empreendeu uma campanha intensiva dirigida ao consumo de alimentos (pouco voltada à produção agrícola), uma vez que esse consumo era considerado um dos pilares da cultura italiana. A unificação em torno de uma cozinha que traduzisse o espírito italiano seria obtida pelo exercício de atividades estendidas a todos os cidadãos e assim foi dada especial atenção às compras e ao preparo dos alimentos, ou seja, reforçar o discurso junto às mulheres, o fulcro dessa política. Outro objetivo subjacente era atingir a auto-suficiência.

A base dessa difusão consistia no uso de discursos científicos, treinamento das donas-de-casa e campanhas para promover os produtos considerados ideais. Nesse caso, era recomendado consumir pouca proteína animal, muito carboidrato (macarrão, pão), verduras e legumes frescos, azeite de oliva, frutas cítricas e vinho. E o consumo deveria ser sempre marcado pela moderação e o uso máximo dos recursos, com um controle disseminado de preços e distribuição de comida entre os menos favorecidos.

Sem muita variedade e quantidade de alimentos, as combinações entre ingredientes era uma saída para tirar a rotina da alimentação, bem como houve uma intensa campanha no sentido de valorizar a produção doméstica de pães, macarrão, bolos, produtos da horta. No entanto, para muitos consumir esse tipo de alimentos era simplesmente morrer de fome, pois faltava carne e calorias para sustentar o corpo para o trabalho, em sua maioria, ainda braçal. As virtudes apregoadas e concentradas nas donas-de-casa tentavam diminuir o impacto causado pela escassez e dificuldades de acesso aos alimentos. Austeridade e simplicidade eram entusiasticamente associadas à italianitá, e serviu como amparo para os atribulados anos de guerra, em que a fome assolou o País. Era um consolo para estômagos vazios que encontraram nas ideias uma forma de amenizar as dores do corpo.

A onda nacionalista que varreu a Itália nesse momento visava a controlar de algum modo o consumo diário de seus habitantes como forma de criar um sentimento de nação e reconhecimento, a comida seria uma forma de coesão para a identidade nacional amparada em seu lado cultural. Essa política teve impactos em diversos aspectos, pois as diferenças regionais, embora permanecessem latentes, ficaram menos evidenciadas ao favorecer a ideia de nação. A melhora da alimentação era pensada como um estágio mais avançado de um processo civilizador que teria como grande meta criar uma Itália fortalecida culturalmente, inclusive, 
com as comunidades de imigrantes que se formavam no Exterior. O governo fascista gastou enormes quantidades de energia para controlar esse aspecto da vida cotidiana, embora seus resultados não correspondessem às expectativas geradas.

A mudança na retórica empregada pela máquina fascista trouxe novos desdobramentos. Se durante as duas primeiras décadas dessa política o alvo era a alimentação italiana orientada para a saúde individual e a produtividade, entre 1935 e 1945 a comida foi alçada a símbolo patriótico, fortalecendo a italianidade ${ }^{102}$. Os vestígios dessa política puderam ser sentidos entre os italianos instalados no Brasil, em especial em São Paulo, embora por aqui não houvesse a fome avassaladora vivida na Europa.

Nesse contexto, o trigo recebeu atenção especial e passou a ser considerado o motor do funcionamento da nação italiana, sendo utilizado como indicador de melhoria do padrão de vida. No período entre guerras, Mussolini chegou a prometer que os italianos seriam libertos da "escravidão" do pão importado, um objetivo que há muito era perseguido pelos distintos governos italianos. Dessa maneira, o ditador estimulou a produção de pão e a pensar o trigo como um produto valioso e tradutor da simplicidade das necessidades da nação e cuidado para evitar seu desperdício, nunca perdendo uma oportunidade de associar sua imagem ao pão.

Ao longo da $2^{\text {a }}$ Guerra a fome foi uma constante entre a população italiana e marcou profundamente aqueles que vieram imediatamente ao fim do conflito para o Brasil. Foi o período marcado pela ideia do "cozinhar com nada" e ainda sob a administração feminina, as memórias dos entrevistados pouco falam sobre esse momento crítico. Há, na verdade, certa fissão de histórias em que distintas trajetórias são unificadas para valorizar um conjunto italiano, fazendo parecer tudo uma única e grandiosa trajetória, independentemente de quando se veio ao País. Engolidos pela força dessa imagem, as memórias dos interlocutores as utilizam para definir posições e, sobretudo, quando envolvem seus restaurantes.

Curiosamente, filhos e descendentes com quem conversei não mencionaram detalhes dos anos marcantes que precederam a $2^{\mathfrak{a}}$ Guerra, bem como não falaram sobre o período do conflito propriamente dito. Foi um momento de grande tensão, especialmente para os italianos, alemães e japoneses, uma vez que seus países compuseram a aliança alvejada pelas forças aliadas. Se os imigrantes já eram vistos com desconfiança, tiveram sua situação deteriorada, estimulando sua retração para o interior doméstico, onde ao menos poderiam exercer suas tradições, falar sua língua e evitar a exposição pública.

Esse ponto levanta outras questões já mencionadas no capítulo anterior, mostrando que não existe uma relação prévia entre nacionalidade e etnicidade, embora diversas correntes locais manifestassem simpatia com relação à ideia de branquear o contingente populacional, o que não amenizou confrontos. Nesse sentido, surgiram modelos que se manifestavam paralelamente bem

102 Fica implícita aqui a noção de raça, que não será discutida neste momento. 
como de maneira mista, em um processo que ignora em certa medida o processo de aculturação, embora inexorável.

As distintas perspectivas marcavam conflitos de identidades que se não mencionados entre os interlocutores, além de uma vaga referência como "boa convivência", marcavam disputas acirradas no plano urbano e fortemente recrudescidas ao longo dos anos em que por um lado o fascismo tentava incorporar culturalmente as comunidades no Exterior e que no Brasil e, em especial São Paulo, dialogavam com as dificuldades de um governo local repleto de ambiguidades.

O período entre guerras gerou o recrudescimento de uma política de incorporação desses imigrantes à sociedade local, e estes por sua vez, mantinham seu repertório cultural menos visível com medo de represálias. A casa e a família serão testemunhas de hábitos e costumes que dizem respeito ao ser italiano, preservados dos olhares públicos e de eventuais julgamentos negativos.

Comida, músicas, costumes se retiraram do espaço público e a cidade italiana do começo século que muito espantava os viajantes que ali circulavam vai perdendo esse colorido multicultural antes exposto a olho nu. A $2^{\underline{a}}$ Guerra colocou por terra qualquer ímpeto cultural italiano e deixou o País à beira de uma catástrofe que nos anos seguintes estimulou à emigração de novos grupos de italianos, facilitadas pelas políticas italianas depois de $1947^{103}$. Contudo, o fluxo não foi retomado com a mesma intensidade, mesmo porque se fazia necessário nesse momento atender a uma imposição do governo brasileiro que passou a exigir dos italianos um contrato de trabalho ou uma carta de chamada. Nesta, parentes locais se responsabilizavam pelo novo imigrante se eventualmente precisasse ser sustentado nos primeiros tempos, fato comum uma vez que muitas famílias mantinham contato com seus parentes ${ }^{104}$.

Nos anos 1950 além desta modalidade individual e da coletiva (grupos para colonização agrícola) criou-se um terceiro tipo que se chamou imigração "dirigida" a fim de convocar trabalhadores especializados. Apesar de uma série de polêmicas que esses atos geraram, tanto na Itália como no Brasil, na verdade esse novo momento da imigração trouxe uma questão mais espinhosa, o emigrado do pós-guerra em nada se parecia com seus antecessores, pois já trazia uma consciência de seus direitos e dignidade que não eram próprias dos primeiros imigrantes. Muitos tinham diplomas e alguns traziam um pequeno capital para se lançar em um empreendimento próprio.

Ante este novo cenário, a cozinha italiana permanecia viva nos limites urbanos, embora sofresse distintas influências multiplicadas em distintas facetas: os imigrantes contam com seus descendentes, não se podem ignorar as ambiguidades da política fascista e dos anos getulistas,

103 Trento (Op.Cit.).

104 Segundo Lesser (2001) entraram entre 1940 e 1949, 15.819 italianos; entre 1950 e 1959, 91.931, diminuindo sensivelmente na década seguinte, para 12.414. 
além dos novos italianos que chegaram ao Brasil em condições bem distintas daquelas vividas pelos primeiros imigrantes.

$\mathrm{Na}$ capital paulista, a austeridade com relação à alimentação não foi em momento algum um aspecto mencionado, tampouco parece que foi uma preocupação tão acentuada como na Itália e nos discursos do Duce. Reforçar o sentimento de pátria e conseguir impor práticas no cotidiano dos habitantes era, inclusive, quase um ponto crucial da própria sobrevivência do regime, mas os italianos no Exterior estavam sujeitos aos humores políticos locais e se Vargas simpatizou com o fascismo em algum momento, sua posição mudou bruscamente ao longo dos anos.

São Paulo não passou pela mesma situação precária em torno do alimento, houve restrição nos anos de guerra, mas era possível conseguir itens básicos, mesmo que de qualidade inferior, embora os melhores estivessem circulando por um mercado paralelo que muitas vezes geravam um comércio intenso. Se o Brasil preferia vender seu trigo para a Europa a preços estratosféricos, importava massas para atender ao gosto dos imigrantes e estimulava o uso de farinha de milho ou outros substitutos para a farinha de trigo, embora não necessariamente a contento da população local ${ }^{105}$.

Naverdade, oracionamentolocal erabastante levee trouxe, sobretudo, consequêncianaadministração do cotidiano doméstico, mas não necessariamente longos períodos de escassez. A preocupação maior era com os parentes que ainda permaneciam na Itália e as poucas notícias que chegavam mostravam um quadro caótico, mesmo entre aqueles que ainda contavam com um pedaço de terra.

Mais uma vez movidos pela ausência de condições de ter uma vida razoável, muitos italianos empreenderam o caminho anteriormente percorrido pelos seus patrícios. A incompetência do regime fascista em sustentar o abastecimento ficou clara, entre os italianos essa decepção foi amenizada pela crença de que a fome era resultante do bloqueio dos aliados e não da inabilidade do Duce, mas trouxe consequências práticas para a vida de inúmeros italianos.

O Duce, curiosamente, foi uma referência bastante assinalada nas memórias, menos como um estadista e mais como uma figura que pensou o bem do País e conseguiu unificar diferenças que até então jamais pareciam ser conciliadas. Ana Maria Carrer não mostrou tristeza pelo fato de sair

105 Na verdade, conforme Cytrynowicz (2004), pão consumido durante o período de guerra era aquele feito em casa de modo caseiro à base de farinha de trigo, em geral, retirada do macarrão que vinha importado da Argentina e que permitia ser cozinhado para formar uma pasta que serviria como pão. Se faltava pão, havia macarrão, o que ressalta o fato de que a escassez não era absoluta. O pão mobilizado para a guerra era escuro e com gosto de milho. A questão toda estava em torno do hábito já criado de consumir pão branco, observado a partir do fim dos anos 1890 e o fato do pão ser escuro criou uma série de protestos, já que estavam acostumados ao pão de farinha bem branca, mais caro nesse momento, porém já considerado apropriado como desjejum matutino. Tal aconteceu, também, com o açúcar branco e o mascavo. Tampouco era fácil encontrar o pão de guerra, normalmente "assassinado" por padeiros de poucos escrúpulos e mais interessados nos lucros. Foi, ainda, nesse período que preocupações em torno da dieta emergiram como forma de garantir a segurança nacional. Ainda segundo o autor, a questão do pão branco ronda outro tema, de maior delicadeza, ao consumir um pão considerado de menor qualidade seria retroceder em termos civilizatórios e destituir a fantasia de ascensão social como nação branca e culta. De qualquer maneira, a solução do pão de guerra foi uma saída para atender ao consumo, embora o problema básico não tivesse sido aventado, ou seja, a produção e circulação de farinha de trigo haviam sido afetadas pelo interesse comercial em vender o produto aos países em guerra. 
da Itália ou mágoa com relação ao percurso de Mussolini, para ela, ele teve um papel importante porque estimulou o "amor à Pátria", opinião semelhante exposta por Domenico DiLaurenti. Eles viveram intensamente esse período e não consideram que houve incompetência, mas um cerco dramático ao País que culminou em uma situação econômica desastrosa.

Domenico Laurenti se declarou simpatizante do Duce, pois "achava bom ter alguém preocupado com a Itália”. A fome, segundo Ana Maria Carrer, não era culpa do Duce, mas sim uma consequência do embargo aliado à Itália ${ }^{106}$.

\footnotetext{
Não tinha nada para comprar, o meu pai vendeu dois apartamentos para termos o que comer, isso foi o que nos garantiu alguma coisa de comer nos anos de guerra. Lembro o dia que comprou dois salames e alguém disse que para conservar mais tempo precisava colocar no azeite de oliva, estragaram claro, mas eu me lembro de minha mãe chorar muito porque perdeu os dois salames.
}

Logicamente que essa perspectiva está suavizada pelos anos de São Paulo e pelas condições de vida razoáveis conquistadas. Mas foi nesse período que a farinha de trigo foi tomada com vigor ainda mais forte como símbolo contra a fome. Em São Paulo, graças aos italianos, o pão também já circulava com desenvoltura e fazia parte do cotidiano das famílias de imigrantes.

Por outro lado, até que ponto a propaganda fascista e a interlocução local afetaram a produção doméstica, é difícil inferir. Não resta dúvida, contudo, que o pão era um produto apreciado e considerado um item básico da alimentação cotidiana e nos anos de Mussolini foi alçado a símbolo nacional. Na cidade de São Paulo o pão tomou um lugar similar, especialmente ao ser um elemento que falava não só de etnicidade, mas também de elementos locais, como a fartura, que viriam a compor o imaginário local e nacional.

No entanto, se os anos foram duros na Itália em função da fome, no Brasil foram anos de desconfiança motivados pelas ambiguidades do governo getulista com relação aos estrangeiros. Era preciso "abrasileirar" os estrangeiros e dessa forma eliminar traços que pudessem estabelecer diferenças muito cruciais, já que na aparência conseguiriam estar próximos dos brasileiros do que os japoneses. De qualquer maneira, escolas de língua estrangeira foram fechadas, ocorreram movimentos para nacionalizar nomes de clubes e associações ${ }^{107}$. A cidade tentava assimilar os imigrantes e tomava etnicidade e cultura como um conjunto homogêneo.

\footnotetext{
106 Em parte, essa observação é corroborada por Trento (1988) quando analisa as motivações que nortearam os emigrantes do período pós-guerra, lembrando que a fome não foi principal entre as várias, mas, sim, a falta de expectativas e a decepção com o governo de Mussolini, e de fato as referências ao Duce, em geral, não foram negativas. Houve talvez uma decepção pela Itália perder a guerra e nesse sentido faltar expectativas de reconstrução do País, no entanto, nenhum interlocutor mencionou esse fato.

107 Os japoneses foram alvos constantes de ações nesse sentido, especialmente no estado de São Paulo. Os alemães sofreram no sul do País com perseguições e violência física. Para uma discussão mais ampla, consultar Cyrtrynowicz (2004). Foi nesse momento que o Palestra Itália se transformou em Palmeiras; para mais detalhes ver Trento (1988) e Bertonha (2005).
} 
Essa rejeição pública aos imigrantes teve um efeito inesperado, especialmente entre os primeiros imigrantes italianos, uma vez que estes não eliminaram aspectos tidos como propriamente de sua etnia e ainda os fortaleceram dentro de suas casas. Nesse sentido, as concentrações de imigrantes em determinadas regiões da cidade tornou-se um problema, uma vez que facilitaria a expressão de uma nacionalidade distinta e não foram poucas as reprimendas, inclusive com a proibição das comemorações festivas ligadas aos santos, único período em que não foram realizadas, como lembrou Ângelo Luisi. Houve, assim, um fortalecimento no mundo doméstico de elementos étnicos considerados importantes, bem menos visíveis publicamente e menos ainda entre as novas gerações.

Foi um período difícil para os italianos que se estendeu pelos anos de duração do conflito (1939-1945). Zanini (2007) abordou essa questão, afirmando que na visão oficial, italianos bem como alemães e japoneses, eram tidos como ameaça ao estado nacional o que teve consequências perturbadoras na imagem desses grupos prolongadas pelas gerações seguintes e pode ter sido, inclusive, um dos mecanismos de opressão de lembranças. Virtudes consideradas próprias do italiano como gosto pelo trabalho, austeridade e respeito à família ganharam espaço para definir as novas gerações, mesmo que abrasileiradas. A comida traduziu em parte esses diferentes cruzamentos e paralelismos, mostrando inclusive que melhorou um paladar monótono e pouco criativo, refletindo-se, inclusive, no plano da identidade paulista.

No entanto, é preciso considerar que do ponto de vista local a realidade que se oferecia aos imigrantes já instalados precisava lidar com um passado de poucas luzes e muito preconceito, embora trabalhado de maneira positiva no imaginário a partir de uma perspectiva que envolve justamente a questão de raça. Sendo brancos, os italianos já teriam vantagens ante outros grupos e, portanto, naturalmente encontrariam um espaço mais apropriado aos seus anseios. Esse conflito, extremamente dissimulado nas narrativas, fica um pouco mais evidente quando chegam novas levas de italianos após a $2^{\mathrm{a}}$ Guerra.

A trajetória de muitos desses italianos é clara e deixa à vista contrastes estimulados pela nova convivência, que expõem novas articulações entre etnicidade, nacionalidade e identidade. Ana Maria Carrer, por exemplo, reúne as condições analisadas até o momento. Seu marido já tinha morado em São Paulo até 1930 quando voltou com toda a família para a Itália e lá permaneceu até logo após o fim da guerra, quando se conheceram e casaram em Roma. Formado em engenharia, foi convidado para trabalhar em uma das fábricas de Francesco Matarazzo, no Belenzinho ${ }^{108}$. "Saí direto de Roma para o Belenzinho", contou ela. "Fui morar na vila operária" e lá construiu boas relações com outros imigrantes, inclusive húngaros.

108 Ela não se referiu, mas esse procedimento era comum os imigrantes desse período, já que para virem ao Brasil precisavam de um contrato de trabalho ou um "ato de chamada" que mostrasse suas possibilidades de trabalho e sustento, em geral emitido por algum parente local, como mencionado em outro momento. 
Ajudada pelos amigos dos sogros que moravam aqui, conseguiu encontrar médicos italianos o que lhe deu segurança para ter seus filhos no Brasi1 ${ }^{109}$. Sua atenção também foi alertada pela quantidade de italianos que circulavam pela cidade, bem como os inúmeros comércios que estes detinham, facilitando muito seu dia-a-dia. Seu pai dizia "Italiano come pasta" e aqui de fato ela percebeu que isso era uma verdade, "ninguém fica sem massa". Um dos motivos de grande orgulho foi o envolvimento de sua família no Circolo Italiano, reavivado no fim dos anos 1940 como um espaço de encontro, embora não conseguisse alcançar o mesmo prestígio que houvera feito sua fama antes da 2" Guerra. "Era coisa de italiano rico", afirmou categórico Alfredo DiCunto.

Fome também estava presente na área rural, como contou Nunziato Petrizzo a Sônia Maria de Freitas (2001) em seu depoimento. Ele disse que todos os seus conterrâneos tinham desejo de imigrar, uma vez que tinham passado muita necessidade. A miséria, no entanto, não era de "faltar alimento", mas de não ter esperança para o futuro, uma vez que a vida era extremamente penosa e não oferecia grandes perspectivas para o futuro. Na verdade, o que se percebe é um desalento em torno do que se pode esperar do futuro e a decisão de emigrar representava um novo caminho que ao menos preenchia esse vazio e muitas vezes criando profundos antagonismos com a geração de italianos já instalados na cidade de São Paulo.

Nesse sentido, ressentimentos de ambos os lados eram alimentados por rancores de distintos matizes e acentuaram a narrativa quase mítica da chegada dos primeiros italianos. Ainda, havia a questão que política que separava italianos entre aqueles que simpatizavam ou participaram do governo de Mussolini e aqueles que se opunham. Com o fechamento de várias escolas, agremiações e clubes, a retomada das atividades dessas instituições tampouco foi imediata e no mesmo ritmo anterior, marcando ainda mais as diferenças entre os grupos, como foi o caso do Circolo Italiano retomado pelos novos imigrantes, mas sem o esplendor de outrora.

Esse fato nos leva a outra questão, estava em curso uma reformulação de identidades movidas pela chegada de novos italianos que expuseram novos conflitos e negociações da italianidade. A vinda de Ana Maria para São Paulo, assim como outros italianos e imigrantes de outras nacionalidades ${ }^{110}$, coincidiu com um período em que a cidade desfrutava de ampla prosperidade econômica. Era o momento de consolidar o projeto de modernização e tentar desaparecer com o passado que remetia à ideia de atraso. A cidade tornava-se auto-suficiente em uma série de produtos e abastecia outras regiões do País, atraindo capital estrangeiro que rapidamente foi investido na malha urbana e em suas redondezas.

A relação entre pujança econômica e identidade não é de todo estranha, especialmente ao levarmos em consideração a análise de Lesser (2001), mostrando as articulações entre ideias

109 No Brasil, houve uma leva de médicos italianos que vieram para trabalhar, como deixou claro o trabalho de Salles (1997) ao analisar a trajetória desses profissionais que se inseriam nas sociedades de socorro evidenciando o caráter étnico desse fenômeno. Consultar também Lesser (Op.Cit.).

110 Ver Freitas (2001). 
de progresso, etnicidade e nacionalidade. $\mathrm{O}$ autor tomou alguns grupos em particular, sírios, libaneses e japoneses, e notou como certas ideias das classes mais favorecidas acabaram tendo resultados contrários ao esperado, especialmente ao implantar uma legislação específica para controlar as atividades empresariais desses imigrantes e resultou em uma concentração desses grupos nas grandes cidades, deixando mais aguda a pluralidade cultural.

Em parte, esse aspecto foi também observado na forma como os primeiros imigrantes se distribuíram pela capital paulista, permitindo que essa concentração estimulasse o gérmen do que anos mais tarde os unificaria, ao menos com relação à imagem construída dialeticamente com a cidade. Para as gerações seguintes que já circulavam com maior desenvoltura, além de mais distanciadas do estigma que marcou os seus pais e avôs, principalmente a aparência e o idioma, a relação entre trabalho, etnicidade encontrava maior ressonância em virtude da trajetória das famílias. Pais e avôs compartilhavam e reforçavam essa imagem e, na verdade, um dos principais antagonismos com o grupo de italianos que entraria após a $2^{\mathrm{a}}$ Guerra ${ }^{111}$.

A cozinha italiana, por sua vez, adquiria substancial participação na paisagem urbana, uma vez que começava a circular para além dos limites étnicos do bairro em função dessa maior circulação das novas gerações ${ }^{112}$, e em especial a partir dos anos 1950 quando novas mãos introduzem novidades na alimentação, cujo principal meio de diversificação foi o grupo de italianos do pós-guerra.

A comida irá continuar sendo um forte vínculo entre imigrantes e tomada como instrumento de italianidade, embora fosse bastante conjuntural. Se as diferenças regionais entre italianos marcaram os primeiros tempos de convívio na cidade, embora em boa medida superados pela organização em torno de uma imagem comum, encontrou reforço neste novo período em que será dissolvida a ideia de imigrante como um ser pejorativo e construída a ideia de italiano. Não foi um processo livre de conflitos, contudo agora serão de outra instância.

O ambiente, segundo Trento (1988), se tornou pesado e suscetível a disputas e rancores como nunca antes observado entre italianos. Na realidade, foi um momento de ruptura em função de um choque de mentalidades e que ficou nitidamente marcado na fala de Aurélio Guzzoni, filho de Fabrizio Guzzoni que foi fundador do Grande Hotel Ca'd'Oro. Vindos após o conflito, foi nítida a maneira como o interlocutor separava o seu tipo de vinda ao Brasil e a dos imigrantes anteriores. Aqui se fez notar a diferença mencionada por Trento, a velha guarda foi aludida como uma espécie de italiano de segunda classe, despreparada e analfabeta que se defrontou com italianos diplomados e alguns com capital. Foi o enfrentamento entre a mitificação do passado

111 Consultar Trento (Op.Cit.) e também Ianni (Op. Cit.).

112 Fausto (1998) indicou uma pista em seu artigo, ao falar sobre as novas gerações que deixavam os bairros étnicos, no entanto, voltavam para suas raízes com sua nova família e muitas vezes a fim de experimentar as comidas servidas nas cantinas. A saída de descendentes dos bairros étnicos é também apontada por Trento ( $O p$. Cit.). 
e do trabalho árduo ante uma nova tropa de recém-aportados com interesses e preocupações muito distintas. E os velhos imigrantes não ficaram satisfeitos diante do desrespeito.

Inúmeras situações de desdém, olhares desconfiados entre uns e outros suscitavam disputas. Por um lado, os antigos imigrantes consideravam que os novos italianos tinham falta de empenho no trabalho, embora pouco se falasse das evidentes mudanças estruturais que a sociedade paulistana havia sofrido, bem como da capacitação desses novos imigrantes, muitos formados e com uma situação intelectual e social muito diferente dos primeiros imigrantes. Além disso, as posturas com relação ao fascismo ressaltaram posições contrárias internas entre italianos.

Os confrontos irão produzir novas relações entre etnicidade e identidade que levarão nesse momento outro elemento que ainda não estava muito claro, a nacionalidade. Nesse sentido, Lesser (2001) apontou para o fato que os imigrantes não assumem uma única estratégia que, para ele, podem ser definidas em três modelos bastante flexíveis e em constante intercâmbio no interior dos grupos: a brancura colocada acima da nacionalidade, o status de classe como diferença, permitindo manter sua etnicidade e os imigrantes e descendentes que relutavam em se fundir à sociedade local.

Para os primeiros imigrantes a italianidade foi um meio de mostrar que não se classificavam apenas como estrangeiros ou imigrantes, fortalecendo o fato de serem italianos e, portanto, diferentes de outros grupos, como os espanhóis. A etnicidade perderá esse sentido à medida que descendentes desses primeiros imigrantes e os novos italianos associaram sua italianidade à classe, embora a questão regional permaneça presente e se tome como um traço diacrítico interno. A ideia de nacionalidade prevalecerá como forma também de se diferenciar frente à sociedade local, nesse sentido ser italiano revelaria maior civilização114, embora o fato de pertencerem a um mesmo país não necessariamente fosse um fator de reconhecimento imediato. As rachaduras se disseminavam entre italianos, mas sua imagem era relativamente uniforme frente à sociedade local ${ }^{113}$.

Naquele momento, estavam sendo cultivadas italianidades que diferenciavam os grupos há mais tempo na cidade e os recém chegados. A categoria imigrante se diluía à medida que ganhava peso a ideia de italiano ${ }^{114}$, uma vez que a Itália adquiria contornos mais precisos como um país. Por outro lado, a velha guarda e seus filhos não tinham uma identidade imutável e, ao enfrentar novos diálogos, as imagens foram revistas. A etnicidade começou a se cruzar com a nacionalidade, ou melhor, nacionalidades, pois perpassava tanto pelo ser italiano como brasileiro. Eram criadas tensões que acentuavam sentimentos ambíguos tanto dos estrangeiros como dos habitantes locais. Por outro lado, a categoria de imigrantes contava com os descendentes, filhos e netos que se tornaram alvos privilegiados de políticas nacionais internas, bem como das

113 Ver Novaes (1993).

114 Pereira (2003) também aponta para esse processo como forma de consolidar a presença italiana em solo brasileiro. 
políticas fascistas. Se houve ressonância ou não desse processo não foi possível entrever nas narrativas, mas é verdade que a ideia de italiano hoje é predominante na maneira de se referir a si, ao grupo e sua contribuição de maneira mais geral à cidade.

Foi fato que diversas tentativas foram empreendidas ao longo da era Vargas para nacionalizar esses imigrantes, extensão de uma corrente de pensamento que se formulou nos Estados Unidos, onde se acreditava ser possível que esses novos habitantes fossem absorvidos pela cultura local em um processo de "americanização". O poder seria dado exatamente pelo fato de vir a ser americano, embora etnicamente resguardasse suas diferenças, especialmente de cor. É a ideia de melting pot, embora nem todos os grupos instalados naquele país obtivessem os mesmos direitos, bem como não se evitou uma política de cotas de imigração ${ }^{115}$.

O coração desse pressuposto era que a sociedade local assumiria os imigrantes e seus descendentes em virtude de um amplo esforço educacional, inclusive na área da alimentação. Ante isso, foram designadas inúmeras ações em escolas e sob a supervisão de assistentes sociais no sentido de ensinar aos estrangeiros no que consistia uma boa alimentação, substituindo seus produtos tradicionais pelo leite e seus derivados, bem como a carne.

No contexto nacional, o panorama sugeria uma ampliação desse conceito de melting pot ${ }^{116}$. A ideia que circulou com maior intensidade foi a de "caldeamento", ou seja, a fusão dos imigrantes e habitantes locais que teria como resultado o "abrasileiramento" desses estrangeiros. $\mathrm{Na}$ verdade, era um processo agressivo em que não bastava ser assimilado, mas apagar passos de uma trajetória cultural nascida sob outras dinâmicas.

Acentua essa preocupação em torno dos descendentes o fato de que uma vez nascidos no Brasil, sua nacionalidade italiana seria transmitida pelo sangue, como em boa parte dos países europeus, mas o brasileiro seria incorporado pelo território ${ }^{117}$. Desse modo, filhos de imigrantes eram considerados "nacionais" e, portanto, deveriam substituir símbolos étnicos de seus pais e avôs por outros que representassem a brasilidade.

As situações variavam, inclusive porque alguns grupos ofereciam maior resistência que outros, embora não deixasse de incorporar elementos locais, uma situação que inclusive nos oferece uma gradiente de percepções bastante rico, pois para alguns a conservação de traços tidos como italianos é um fato consolidado, paradoxalmente, as conquistas chegaram porque o italiano soube se adaptar. As memórias refletem essa oscilação entre aceitar uma condição de italiano e outra de brasileiro que, sem dúvida, é situacional. Dessa forma, acondicionar nacionalidade e etnicidade

115 Para uma discussão mais ampla, consultar Baily (1999). O autor analisou o contexto argentino, notando que os italianos encontraram um ambiente menos hostil e com maiores facilidades para sua adaptação do que nos Estados Unidos.

116 Ver Seyferth (1997).

117 O que inclusive permitiu que muitos netos e bisnetos de italianos obtivessem cidadania italiana, estimulados pelo fato de que a Itália se tornou um país economicamente estável e muitos fizessem o caminho inverso ao de seus ancestrais, voltassem para as origens em busca de oportunidades. 
de forma significativa entre os membros de um grupo sem muita coesão nos oferece uma busca por símbolos que teriam um caráter instrumental para poder ir e vir entre uma e outra condição. A cozinha teve um papel particularmente forte e mais uma vez acionada ante os novos enfrentamentos levantados a partir da chegada de italianos no pós-guerra.

A italianidade, portanto, nunca foi uma condição fechada, ao contrário, estava sob a influência de distintos fluxos que criavam respostas em função daquilo que enfrentava. Era perceptível a manifestação de italianidades em distintos níveis a partir destes encontros e desencontros: entre os antigos imigrantes e os novos, aqueles que voltaram para a Itália e resolveram retornar ao Brasil, entre os de origem humilde e aqueles com alguma profissão ou preparo, os que vieram do norte da Itália e os que vieram do sul. Além da complexidade dessas articulações, era preciso confrontar as políticas italianas fora do País junto à realidade nacional.

O caso dos italianos que foram e retornaram é ainda mais sugestivo dessa inadequação e um aspecto estrutural da imigração italiana praticada para o Brasil ${ }^{118}$, fazendo com que milhares de italianos não encontrassem reconhecimento pleno em um lugar e outro, embora esse processo por si só já traga novas interpretações e abra margens para novas transformações.

Dessa maneira, não é de se estranhar que muitos imigrantes só tomassem ideia do que é ser italiano quando afastados de sua terra natal, até mesmo porque muitos ao saírem de seu país eram napolitanos, calabreses, toscanos, vênetos etc. Era uma época em que nem se imaginava o mundo global e os dialetos, bem como as tradições regionais, predominavam no cenário da península italiana derivando disso certo isolamento entre as regiões. Os regionalismos foram, em parte, superados frente às necessidades impostas na nova sociedade, mas terão de lidar com os novos conteúdos nacionalistas que se propagam de distintos lados: local e da terra natal.

Forjar uma nova identidade não era, então, um projeto claro, mas foi feito a partir de bases dramáticas de um cotidiano que expôs os imigrantes a situações, se não vexatórias, constrangedoras e que seriam vencidas a partir do contexto do pós-guerra. A velha guarda se amparava na nostalgia e nos anos duros de trabalho, os novos imigrantes na sua ideia de nação italiana e sua capacidade intelectual para superar obstáculos e conquistar um espaço apropriado. As memórias não mostram esses impasses, mas auxiliam a pensar sobre eles e os motivos pelos quais desapareceram das narrativas.

A cozinha italiana não esconde esse paradoxo, ao mesmo tempo em que se mostra integrada à Itália, ela não descarta sua influência local e, por isso, muitas vezes perde valor ante os italianos, especialmente entre aqueles vindos mais recentemente. Ela fala da velha guarda e de

118 Ianni (Op.Cit.). Segundo o autor, não eram poucos os que viviam nesse ir e vir, muito embora nem todos desfrutassem de condições econômicas suficientemente confortáveis para tanto. Mesmo repatriados, o sentimento é de inquietude e sentem-se profundamente infelizes quando não podem mais voltar ao Brasil, convivendo com um arrependimento quase sempre ácido. Aqueles que preferiam guardar suas economias e abrir mão de uma visita à Itália, também sentiam que haviam perdido algo de sua alma nessa escolha, mantendo vivas as imagens da terra natal apenas na memória. Ver também Alvim (1986). 
suas estratégias para recriar um mundo italiano, mas também fala de como conseguiu um lugar na nova sociedade, mesmo que só as novas gerações pudessem desfrutar.

Essas ambiguidades pareciam não ser levadas em conta pelas campanhas empreendidas pelas autoridades e classes privilegiadas, preocupando-se em educar os imigrantes e incorporálos à nova sociedade. Na verdade, tentavam dissolver aspectos culturais que eram considerados pilares da identidade, como a língua e a comida, de modo que uma vez deixada essa lacuna, seria possível preencher com novos elementos de cunho nacional e, assim, estimular a adoção de uma identidade nacional.

Os encontros entre imigrantes geravam um convívio estreito e cotidiano e a comida, como foi possível entrever no capitulo anterior, rapidamente encontrou meios de se reproduzir. Pães e massas, além do molho de tomate, fizeram sua estreia local e rapidamente foram classificados pela sociedade local de comida italiana, embora as diferenças possivelmente estivessem presentes. A consciência de ser italiano também era gerada desde o olhar do Outro e a comida não deixou de ser submetida a essa mesma lógica.

Os imigrantes, especialmente a velha guarda, eram em sua maioria do sul e valorizavam as massas, embora oferecessem muitas diferenças como apontou Alfredo DiCunto:

\begin{abstract}
Então, naquele tempo só conhecíamos o macarrão seco, o talharim, só, mas... nós ouvíamos falar de caneloni, e eu ouvi falar de lasanha, coisa que eu nunca tinha visto. Então, tortelini, ravióli, era... isso a gente ouvia falar só em nome, nunca tinha visto. Então esse caneloni era da região de Roma e... a lasanha era da Emilia Romana, tortelini também era...da região de Bolonha e foi então, tudo essas coisas eu vim conhecer aqui no Brasil [...]
\end{abstract}

Na categoria massas, a variedade era tanta que pequenos povoados a pouca distância tinham suas próprias especialidades contou o interlocutor, e esse conhecimento foi reproduzido na capital paulista, embora criando soluções que dariam à cozinha dita italiana praticada por esses imigrantes elementos bem distintos daqueles encontrados na terra natal. Assim, cozinha italiana adquiria um sentido bem distinto na capital paulista, como até mesmo notou Ana Maria Carrer, ao dizer que veio conhecer "comida italiana" no Brasil, pois antes vivia presa aos elementos regionais que conhecia.

Esse é um dos aspectos que afetavam o convívio entre italianos e não moldou de imediato um grupo consistente e coeso, muito mais real na imaginação do que na realidade. A ideia de nação como um todo ainda estava em formação e foi ganhar força efetiva à medida que as novas levas de italianos do pós-guerra vieram somar-se aos imigrantes e seus descendentes.

E se for considerado os distintos esforços empreendidos por lados opostos para angariar essa vasta massa de pessoas, jogando com a noção de cultura italiana de um lado, e com abrasileiramento do outro, era necessário garantir a sobrevivência e ante isso comer é uma 
necessidade premente. A manifestação da italianitá estimulada por esse caminho se viu ameaçada pelas políticas oficiais conduzidas por Getúlio. Na verdade, essa situação contribuiu para assentar uma identidade que transitava entre dois mundos, uma identidade hifenizada e acionada conforme as circunstâncias que se apresentavam ${ }^{119}$.

O convívio entre italianidades produzidas a partir de pontos de partida distintos tornou-se uma realidade, de um lado a velha guarda preocupada em resguardar sua imagem a partir do trabalho e empenho, imagem repassada às novas gerações que não tinham tanto interesse em manter hábitos e costumes de seus ancestrais. A razão disso poderia ser atribuída às inúmeras restrições em torno da manifestação de sua italianidade e certa vergonha pela trajetória familiar, este último ponto fartamente utilizado pelos novos italianos para demarcar certa superioridade com relação ao primeiro grupo.

Nas memórias dos interlocutores esses desentendimentos praticamente desaparecem, embora possam aparecer levemente quando a pessoa entrevistada pertence ao grupo mais recente. Uma diferença interessante entre as narrativas diz respeito ao papel das mães. Para os menos prósperos ou cuja família veio antes da $2^{\mathrm{a}}$ Guerra, em geral há maior relevância da mulher nas falas, ao contrário dos grupos de italianos em posição mais favorecida ou que vieram após a $2^{\mathrm{a}}$ Guerra.

Ela será para as famílias de menor prestígio o elo propulsor de uma trajetória ascendente, uma vez que estaria preocupada com o bem-estar geral, com o uso dos recursos, com a educação dos filhos. Nesse sentido, a comida seria central por diversos fatores, em parte porque agregaria os membros da família, embora não fosse costumeiro nem mesmo na Itália realizar refeições em conjunto122, e mostrar sua habilidade no orçamento da casa. No entanto, ao oferecer determinadas comidas reforça-se um sentido de quem somos, pois é na família onde as crianças têm os primeiros contatos com a comida e uma noção de identidade ${ }^{120}$.

A mãe seria o elo entre distintos mundos, aquele que ficou para trás e este que está sendo vivido e cujo futuro em parte está sob seus encargos. Ela aciona a nostalgia, mas também sabe que é preciso criar meios de se comunicar com a nova cidade. A mãe protege, mas também permitirá ao filho lançar-se na empreitada de uma vida desconhecida. E por esse caminho, as distâncias vão sendo diminuídas, o exótico ficará mais suave e a comida percorrerá novos caminhos.

A mulher normalmente atrelada às tarefas do cozinhar acabou centralizando a imagem da cozinha italiana e consolidou o imaginário das mammas, muito presente nas cantinas. Estes espaços nasceram sob os auspícios étnicos e de frequência masculina que a partir

119 Para aprofundar esse debate, consultar Lesser (Op. Cit.).

120 Para essa discussão, ver Fischler (1990). 
dos anos 1950 ficaram associados à família, à partilha de refeições, à comida de casa, uma reação quando confrontados aos novos restaurantes que surgiram nesse período.

Em parte o processo analisado da participação feminina na constituição das primeiras cantinas dizia respeito a uma estrutura familiar, econômica e social condizente com essa atividade. Esse ponto começou a ganhar peso à medida que o papel da mulher ficava circunscrito ao lar, especialmente responsável pelo andamento adequado das tarefas domésticas, criação dos filhos e cuidados com o marido. Era um ímpeto moralizador que teve na mulher um foco privilegiado e tentava reproduzir valores e ideais de camadas privilegiadas entre as massas proletárias ${ }^{121}$. Um ponto, inclusive, que não deixa de ser paradoxal, porque se de um lado as camadas privilegiadas atacavam os imigrantes pela ausência de um poder civilizador, por outro não sentiam remorso pelo fato de explorarem mulheres e crianças como mão de obra, muito mais barata e dócil.

As mulheres italianas não passaram desatentas ao discurso e muitas sentiram a necessidade de se dedicar ao lar e percebendo-o como um santuário familiar, aspecto inclusive enfatizado nos discursos médicos e sanitários. A organização da casa, a criação e educação dos filhos seriam responsabilidades femininas que permitiriam ao homem obter as condições necessárias para que pudessem trabalhar sem preocupações com o preparo da alimentação, limpeza, cuidados com filhos. Era a ideia de que uma vez o universo doméstico ordenado, a vida na esfera pública corresponderia de maneira equivalente.

A mãe seria a guardiã desse novo modelo e a infância adquire um papel central, inspirado em um exemplo cujas origens remontam ao tempo vitoriano. As mulheres seriam naturalmente programadas para a maternidade e vida doméstica, bem menos presentes nas fábricas já nos anos 1930, embora muitas mulheres continuassem a realizar trabalhos em suas casas para as indústrias como bordados e costuras, o que não colaborava em melhorar sua imagem. Entretanto, esse tipo de trabalho é mencionado por alguns interlocutores e é em muitas ocasiões um aspecto referido com orgulho, pois evidencia a importância do trabalho ${ }^{122}$

A intervenção na alimentação dos imigrantes não ficou muito clara no exemplo paulistano, embora algumas pistas sugiram que houve um esforço nesse sentido, sobretudo quando há a preocupação de higienizar os imigrantes, tanto no que concerne à moradia, como aos hábitos cotidianos e possivelmente à comida. Não se sabe ao certo o quanto se conseguiu

\footnotetext{
121 Rago (1985).

122 Consultar Matos (2002).
} 
influenciar as mulheres ou crianças ${ }^{123}$.

De qualquer maneira, o fato de o pão e as massas circularem com desenvoltura na cidade permitiu dar certa homogeneidade à cozinha italiana, ao menos ante os olhos locais, embora formatos e aspecto desses produtos pudessem variar e causa estranhamento entre os próprios italianos. Mas é fato que nas comunidades italianas instaladas nos países de imigração, macarrão com molho de tomate teve um papel catalisador para a imagem dessa cozinha e da italianidade. No contexto local, foi a partir dos anos 1950 e 1960 que essa dupla será ainda mais reconhecida, pois será a principal oferta de refeições fora de casa e o lazer familiar começará a incorporar o hábito de comer fora.

Tomate e queijo, segundo sugere Capatti (2001), eram ingredientes acessíveis à população desfavorecida que os costumava utilizar para melhorar o sabor dos pratos, sobretudo das pizzas encontradas em Nápoles e marcava a “comida de pobres”. Um novo aspecto pouco referido, mas que pode dar sentido ao comentário pouco favorável emitido pelo entrevistado, pois há ainda que se notar que macarrão e molho de tomate foram tomados como emblemas da italianidade, mas não abandonaram seu viés popular, especialmente porque boa parte desse imaginário tem raízes nas comunidades de italianos instaladas no estrangeiro.

Massas e molho de tomate podem ter sofrido desconfiança como deixaram claras as observações de alguns memorialistas, mas houve uma confluência de fatores que permitiu a inserção cada vez mais profunda dessa cozinha nas cidades em que a imigração italiana foi expressiva. Ajuda extra veio pelas intervenções fascistas, incentivadas pela indústria que exportava massas secas e latas de molho de tomate para as comunidades no Exterior. Contou também com a busca desses imigrantes por uma identidade, buscando amparo em certos elementos, como a comida.

Além desses fatores, é fato que na década seguinte após o fim da $2^{\mathrm{a}}$ Guerra, a cidade de São Paulo teve um surto cultural e disso fileiras de novos grupos, muitos ligados aos meios de comunicação e artes, tomaram o espaço público. Restaurantes e bares, antes praticamente

123 Segundo Levenstein (2003 a), nos Estados Unidos se observou algo semelhante. Várias tentativas foram feitas no sentido de mudar os hábitos alimentares dos imigrantes italianos no intuito de fazê-los incorporar maior "americanidade". Não foram poucos os conflitos em torno dessa ação, inclusive criando desavenças familiares, especialmente o hábito de consumir cereais no café da manhã representava para muitos italianos comer como animais. Nesse caso, não era rara a dificuldade de adaptação ao ambiente e sofrerem com o estigma de serem estrangeiros. Quando crescidos e já formando família, os filhos desses imigrantes abandonavam facilmente os hábitos de seus pais, buscando reproduzir hábitos reconhecidos como "norteamericanos". Foi nessa transição que o uso do alho foi praticamente abandonado, um ingrediente vastamente presente na cozinha do sul da Itália, especialmente da Sicilia, origem de boa parte dos imigrantes que se dirigiram para aquele país. Contrariamente, o macarrão com molho de tomate consumido pelos imigrantes italianos conquistou tamanho espaço que conseguiu perdurar apesar das intervenções e transformado em prato popular entre os locais. Nesse sentido, desempenhou um papel central na constituição do setor de restaurantes e teve uma rápida disseminação quando se consolida o hábito de comer fora de casa, especialmente a partir de meados dos anos 1950. 
inexistentes emergem como lugares das novas sociabilidades paulistanas. As modestas cantinas étnicas que surgiram para atender a membros de uma comunidade em formação começaram a receber outros habitantes da cidade, especialmente filhos de italianos que, ao prosperarem, foram viver em outros bairros, mas não deixavam de voltar às origens em busca dos mesmos sabores e quiçá sensações de outrora.

É neste momento que a cidade emerge como um pólo intelectual, das artes e comunicação. Junte-se a esse fenômeno o fato de que muitos imigrantes italianos e, especialmente seus filhos, alcançaram ocupações de maior prestígio, passando a ocupar um espaço social menos inferiorizado e mais evidente, embora menos marcado pelos elementos étnicos que definiram seus pais e avôs.

Posição social mais favorecida, diluição de alguns traços mais marcantes permitiram também um maior convívio entre descendentes de imigrantes e população locais, até mesmo estimulando casamentos entre distintos grupos, um fato novo, pois até então eram raros os enlaces entre distintos grupos étnicos e locais. É possível que esse maior arejamento tenha promovido a incorporação de novos hábitos entre os filhos e netos de imigrantes, mas também descortinado novos aspectos de seu cotidiano aos habitantes locais ${ }^{124}$.

Novas ocupações profissionais surgiam, bem como o uso do espaço urbano estava em plena transformação, o centro da cidade já era um palco de sociabilidades de camadas favorecidas, mas vai mudar o seu ponto de convergência. A partir dos anos 1950 o Teatro Municipal, a Rua Barão de Itapetininga, a Praça da República serão os redutos de novas sociabilidades e encontros entre camadas privilegiadas, que contarão com a participação de uma incipiente classe média.

O Brás sofrerá nesse período uma evasão de moradores, permanecendo os mais antigos ou arraigados, como lembrou João Donato. E é também no fim dos anos 1960 que esse bairro irá sofrer o pior golpe, segundo alguns interlocutores, pois será tomado pelos novos migrantes, os nordestinos. Os italianos já se sentiam mais confortáveis de circular para além das fronteiras de seus bairros, uma vez que a tensão gerada pelos anos anteriores à Guerra e mesmo durante o conflito começava a se dissipar.

Giovanni Bruno relatou em suas memórias (BRUNO, 1994) que o centro estava ficando luxuoso, havia agitação nas Avenidas São João e Ipiranga onde as pessoas procuravam lazer em restaurantes, cinemas e teatros, principalmente no início dos anos 1960,

São Paulo era muito diferente. As pessoas iam até o centro da cidade para tomar chá nas confeitarias, ira os desfiles de moda no Mappin, fazer compras na elegante Rua Barão de Itapetininga, ir ao cinema e, em algumas ocasiões,

124 Van Otterloo (2002) notou um processo semelhante entre imigrantes italianos em Amsterdã, lembrando que os casamentos entre locais e estrangeiros foi também um forte impulso ao intercâmbio de sabores, criando inclusive combinações que aos olhos de italianos contemporâneos soavam demasiadamente estranhas como macarrão com repolho. Ver também Fausto (1988). 
assistir às temporadas líricas do Teatro Municipal [...] Para muitos, ir ao cinema ou ao teatro era um grande acontecimento, muitas vezes programado com antecedência e que, inevitavelmente, incluía um jantar em um dos poucos restaurantes da cidade. Na época, não existia a diversificação e a quantidade atual de restaurantes. A expansão desta atividade nos Jardins era algo além da imaginação. Portanto, jantar fora era uma prática pouco comum. Assim sendo um restaurante devia estar preparado para receber com requinte tanto seus clientes habituais, como aqueles frequentadores ocasionais, que chegavam vestidos elegantemente. Todos eram muito exigentes quanto ao atendimento, que teria que ser impecável. (1994, p. 81)

Esse aspecto é corroborado por Aurélio Guzzoni:

\begin{abstract}
Não tinha na época (1956) bons restaurantes italianos (em São Paulo), meu pai introduziu uma cozinha do norte [...] trouxe receitas clássicas, centenárias. Trouxe com ele dois chefs de cozinha que fizeram escola na cidade, Emilio Locatelli e Alberto Micheletti, mais dois gerentes, todos solteiros [...] e com o acordo que ele fez ficaram no restaurante até morrer. Esses dois cozinheiros foram uma escola para São Paulo. Formou muita gente hoje famosa, como o Giancarlo Bolla que segue uma cozinha clássica da Itália até hoje e que teve oportunidade de aprender conosco.
\end{abstract}

Giovanni Bruno lembrou que nesse momento, por volta de 1949, a cidade não tinha muita oferta de restaurantes e ele veio a chamado de seu pai para trabalhar. Ele descreveu aquele momento com nostalgia, uma perspectiva de oportunidade que ele veio aproveitar em uma cidade que crescia rapidamente. Não existia sujeira, medo de andar na rua e o centro era um lugar "espetacular". Ele disse que:

Com seus quase cinco milhões de habitantes (naquela época), São Paulo estava em pleno crescimento. $\mathrm{O}$ centro da cidade ainda conservava muitas características oriundas da Europa e demoraria alguns anos para entrar no irreversível processo de deterioração que ainda hoje continua.

No plano da comida essas diferenças ficaram marcadas na introdução de novos sabores pelos italianos que chegavam nesse momento. Apesar das dificuldades enfrentadas, o preparo intelectual e cultural mais apurado que de seus antecessores permitiu que prosperassem com alguma facilidade. Muitos dos que se aventuraram por aqui começaram como pequenos empresários, alguns já tinham experiência prévia ao exercerem funções ligadas a restaurantes e hotéis, como foi o caso da família Aurélio Guzzoni e de Mario Tatini.

O grupo de imigrantes italianos nunca foi homogêneo, mas neste momento em especial é que se dá uma ruptura abrupta, inclusive observada na comida. Apesar de todos os regionalismos que compuseram essa cozinha nos primeiros anos, prevaleceu coesão em torno da etnicidade e na formação de uma identidade que pudesse estabelecer um lugar para esses imigrantes. É neste 
período que a nacionalidade entrará como um componente representativo, embora segundo as circunstâncias, refutada a favor das diferenças regionais. Estas serão resgatadas sob uma perspectiva em que progresso econômico equivalerá ao conceito de civilização com diversos impactos no cotidiano, até mesmo na comida servida em restaurantes.

Por outro lado, é preciso pensar que a cidade ofereceu maior abundância de alimentos aos imigrantes, nem tanto pela variedade de ingredientes, mas pela facilidade em acessar a farinha de trigo, a base da cozinha italiana praticada em São Paulo. E esse aspecto pode ter trazido desdobramentos interessantes ao pensar a noção de fartura, pois se a disponibilidade estava dada, o exercício da cozinha italiana multiplicou as opções de resultados, mas os confinou durante anos ao consumo interno ${ }^{125}$. A comida italiana não representava algo comestível localmente, apesar de certa disponibilidade e com o correr dos anos tornou-se extremamente aceitável e parte do lazer urbano. Não se trata de uma necessidade ou utilidade, na verdade houve a incorporação de novas circunstâncias ao comer que permitiu o transbordamento de fronteiras.

No fundo, existem diferenças sutis nessa trajetória, por um lado é preciso pensar a comida italiana desde sua perspectiva cultural, mas também como se articula ao social, mostrando que existem italianidades convivendo entre si, com distintos ritmos e escalas. No encontro entre italianos que falavam desde perspectivas muito diferentes a ruptura tornou-se evidente e nem tanto frente à sociedade local.

Nesse ponto, é curioso perceber como a cozinha italiana dos imigrantes até então desprezada passará a ser bem aceita, denotando articulações que se não estavam ativas, passaram a ter sentido nesse momento. A comida possui e acionará sua capacidade de transmitir novas mensagens, de formar novos espaços para consumo e a consequente aquisição de capacidades para fazê-lo, bem como a ligação entre comida e corpo terá novos registros ${ }^{126}$.

No fundo, trata-se de um rearranjo do acesso e do conhecimento promovido pelas novas levas de italianos vindas a partir do fim dos anos 1940. Trava-se uma interessante distância entre a produção do alimento (seus aspectos técnicos, sociais, culturais, estéticos etc.) e o seu consumo. Em ambos os momentos são produzidas identidades. Esse ponto é fundamental para pensarmos os restaurantes que surgem nesse momento, uma vez que o mundo da produção do alimento e o mundo do consumo estarão entrecruzados.

A leitura que deve ser feita dessa descontinuidade nos poderá mostrar como a formação de identidades impactou os restaurantes e vice-versa, especialmente porque até não muito tempo eram espaços raros e quando surgiram estavam associados ao mundo dos imigrantes italianos. A produção modesta de pratos de cozinha italiana e a quem se destinam trará desdobramentos

125 Para uma discussão das categorias desperdício e opulência no contexto nacional, consultar o artigo de Kant de Lima (1993).

126 Para uma interessante discussão sobre o consumo e a atribuição de sentidos às coisas consultar Appadurai (2003) e Douglas \& Isherwood (2004). 
aos restaurantes e às percepções de quem consome sua comida, cruzando o étnico, o italiano, o cosmopolita e o autêntico.

Eram antagonismos próprios de italianidades que se sobrepunham em uma realidade nem sempre suave. Encontros e desencontros demarcavam os distintos interesses de grupos no interior de uma comunidade que começava a construir seus limites. Na verdade, emprestando a definição de Anderson (1991), não se pode dizer que era comunidade com caráter falso ou verdadeiro, mas imaginada e sustentada por diferentes alicerces, cuja solidariedade teria o intuito de superar divergências e solidificar a ideia de sua colaboração no progresso da cidade.

A cidade incorporou essa contribuição e até mesmo a tomou como uma particularidade fundamental de sua posição privilegiada, metrópole cosmopolita. Para os italianos, a cidade representou progresso, sobretudo material, mas de fato não houve nas memórias uma associação de sua presença aos ícones da modernidade que caracterizaram esse período.

O discurso da colaboração italiana na prosperidade paulista se valeu da modernidade como contribuição, mas não deixou de lado a fonte da velha guarda italiana, mexida com a entrada de novos italianos, que também tentava impor sua presença após anos de desprestígio. Eram disputas de reconhecimento e posição mais acirradas em função dos arranjos que se constituíam na cidade. Se hoje partilham uma noção semelhante em torno do papel dos imigrantes, em parte isso deve ao discurso promovido pelos setores políticos e camadas urbanas, que de certa forma deixaram subjacente a questão do progresso derivado de um elemento humano superior, nesse caso o europeu.

Avanços econômicos, progresso, civilização foram ainda reforçados pela entrada dos italianos no universo das artes, estimulando vários segmentos como o cinema, teatro, música. Era um trabalho especializado e inovador que contou, ainda, com o mecenato exercido pelos imigrantes prósperos, especialmente italianos, que influenciaram a cena cultural paulistana $^{127}$.

Aliado a esse fenômeno, os anos 1950 dão início à influência norte-americana, especialmente na exibição de filmes que tinham um apelo proveniente do mundo da publicidade, incentivando a adoção de um estilo de vida calcado nos Estados Unidos ${ }^{128}$. O cenário é amplo e instigante para pensar como nessa complexa teia de relações a cozinha italiana ganhou destaque, saindo de uma posição subalterna para conquistar um lugar privilegiado, mostrando que a italianidade que a sustenta sempre será incompleta.

\footnotetext{
127 Arruda (2001).

128 Nesse sentido, é interessante a análise feita por Garcia (2004) em torno das mensagens contidas em revistas destinadas ao público feminino dessa época, cujo direcionamento era moldar um estilo de vida condizente com o modelo norte-americano.
} 


\section{Restaurantes: disjunções na cozinha italiana}

De caráter instrumental, mas também simbólico, a cozinha italiana exercida nesses primeiros tempos acionava os limites étnicos de um grupo que era visto de esguelha pelos habitantes locais e percebidos sob uma grande categoria, "imigrantes" 129 . Inicialmente, graças ao seu caráter étnico, essas cantinas estavam circunscritas aos bairros de italianos, como Brás, Mooca e Bixiga ${ }^{130}$. Era comum começarem a trabalhar à noite, como observou João Donato, mas não serviam pizza ou massa, na verdade essa separação ocorreu mais recentemente.

Segundo já mencionado por João Donato, o Brás tinha inúmeras cantinas abertas a partir dos anos 1920 e não aguentaram a pressão de novas forças, especialmente a partir dos anos 1960 . Em parte, esse processo reflete as mudanças observadas nas gerações seguintes que lentamente se dirigem para outras regiões, como os bairros de Vila Mariana, Perdizes, Paraíso etc. Por sua vez, o Brás testemunhava uma completa transformação ao receber milhares de imigrantes nordestinos vindos para trabalhar na construção civil, a "baianada", definição dada por vários interlocutores.

Segundo João Donato, é neste momento que o Brás perde parte de seu encanto e vai tendo suas feições transformadas. Não se reconheciam as pessoas pelas ruas, os rostos se tornavam desconhecidos. Porém, foram esses mesmos desqualificados que ocuparam as cozinhas dos restaurantes, inclusive das cantinas, absorvendo com rapidez o preparo das receitas e reproduzindo-as com perfeição. Saíam da cozinha mulheres e imigrantes sem qualificação para dar lugar a outros desfavorecidos, agora não mais estrangeiros, mas nacionais gozando de pouco ou nenhum prestígio.

Era um processo que começava a movimentar as posições entre classes e criar outras classificações, especialmente fortalecendo a ideia de que os italianos tinham de fato alguma superioridade para conseguir conquistar novas ocupações de maior reconhecimento. Quando Giovanni Bruno contou sobre sua trajetória, esse ponto é velado, mas parece querer vir à tona, especialmente ao dizer que nunca aprendeu a dirigir porque "não tinha tempo, eu só trabalhava [...] mas veja você, hoje até tenho uma rua com meu nome [...] pelo serviço que prestei à cidade." Ele disse que assim agia sempre, pois "As promoções demoravam naquele tempo e tinha muito medo de fazer algo e ser despedido", por isso não se importava em estender seu horário de trabalho e, com isso, ganhando alguns pontos com os seus patrões.

Com as transformações na cidade, o Brás começou um processo de decadência e abriu espaço para que o Bixiga se firmasse como um bairro italiano por excelência e onde a comida italiana seria encontrada em sua forma ainda verdadeira, nas cantinas. A distribuição de restaurantes

129 Processos semelhantes são discutidos por van den Berghe (1984) e van Otterloo (2002), pensando na questão da imigração e grandes cidades.

130 Consultar Anexo, Apêndice 3. 
ainda era tímida naquela época, lembrou Afonso Roperto, proprietário da Cantina Roperto instalada na Rua 13 de Maio, no Bixiga, mas já existiam alguns estabelecimentos. Seu avô teria aberto uma cantina na Rua Major Diogo, na época "Eram meia dúzia de restaurantes aqui no Bixiga e umas padarias e é claro tinha o Capuano, famoso pelo mau humor e boa comida". Para ele foram esses elementos, associados aos imigrantes italianos do bairro que fizeram com que as cantinas da região ganhassem atenção.

É nesse período que as cantinas reforçam seu repertório de massas, molho de tomate e queijo como índices de uma cozinha italiana tradicional, sobretudo porque estavam amparadas no conhecimento das mammas que as praticaram desde que se estabeleceram na capital paulista. No entanto, esse tipo de comida será contestado pelos novos italianos que, em sua maioria vinham da região norte da Itália, e estranhavam a quantidade de molho de tomate e pizzas dessa dita cozinha italiana. Instituía-se um embate entre o velho e o novo, entre sul e norte, rural e urbano, rústico e intelectual.

A produção dessa comida estava intrinsecamente ligada aos conflitos que marcaram esse encontro e nesse momento incorporaram elementos que falavam para além do étnico. Era uma disputa de conhecimento, de lógicas que ainda estavam arraigadas na circulação de bens amparadas nas relações de proximidade e vizinhança ante uma lógica que começará a incorporar a ideia de produção fabril e dos relacionamentos individualizados e sem rosto.

A recomposição desses estilhaços ocorria no convívio entre esses diversos grupos que começavam a circular pela cidade e encontravam nos espaços dos restaurantes formas de expressar distintos estados de espírito. As origens humildes e o tempo transcorrido desde a imigração eram sinais evidentes de que os italianos e seus filhos estavam perdendo parte da cultura italiana, ou pelo menos da cultura que se desenvolvia na Itália. A cozinha como uma prática cotidiana, mas também extraordinária como nos restaurantes desse momento, permite vislumbrar algumas negociações em andamento.

São distintas camadas que vão acomodando mudanças em torno da família, da origem regional, da Itália como nação, do Brasil como o novo país "de coração". Tudo isto enfrentando transformações radicais no cenário urbano e o preconceito dos que ficaram na Itália, uma vez que consideravam esses imigrantes como já incorporados aos países que escolheram viver. A velha guarda tinha na comida uma representação da importância da família, do envolvimento da mulher em sua produção, do trabalho e da cooperação como meio de prosperar, elementos de sua trajetória engessados na memória de receitas que falassem de suas raízes, sem descuidar do que foi necessário incorporar ou descartar ao longo desse percurso.

Curiosamente, a comida italiana dos restaurantes tentava transmitir certa noção de pureza, embora as substituições e incorporações fossem necessárias, não só por não dispor dos mesmos ingredientes, mas também porque muitas receitas concentradas apenas nas memórias de família 
e mulheres podem ter perdido elementos pelo caminho e reprodução. De certa maneira, o restaurante contribuiu para fortalecer tipos de cozinha italiana que falavam de nostalgia, mas também do novo e o crescimento urbano teve uma ampla contribuição nesse processo.

A italianidade dessa velha guarda estava concentrada nas cantinas, mas também começava a constituir-se uma noção mais clara de nacionalidade, estimulada pela vinda de imigrantes no pós-guerra, dissolvendo fronteiras e criando outras. Um aspecto que não deixa de ser paradoxal, pois se as novas gerações estavam desejosas de criar suas raízes no Brasil, a influência da Italianidade não desapareceu por completo, embora adaptada a um novo contexto. A cantina e sua comida dialogavam com essas questões sem esconder dificuldades em lidar com uma nova organização.

Os restaurantes da cidade de São Paulo não se furtaram a esse paradoxo. Em primeiro lugar, comer fora de casa não era nem mesmo uma prática comum, na verdade só veio a se constituir como tal nos anos 1980, como será visto no próximo capítulo. Apenas alguns membros de camadas favorecidas costumavam sair para confeitarias ou salões de chá, onde consumiam doces e sorvetes, conforme analisado anteriormente, demarcando uma distinção entre classes, como parecem indicar referências em torno do assunto.

Nesse sentido, a partir dos anos 1950, os restaurantes começaram a surgir com alguma visibilidade, embora ainda não fossem muitos. A maioria pertencia a imigrantes italianos e, portanto, ofereciam um vasto repertório de pratos inspirados a partir de seu conhecimento culinário. As cantinas enfatizavam a cozinha italiana dos imigrantes e com forte apelo étnico e até então, de gênero, pois era uma comida basicamente destinada aos homens, embora em boa parte produzida por mulheres.

Ao seu lado emergiram diversos tipos de estabelecimentos alguns mais refinados, outros menos, mas que trariam à tona uma profunda diferença com relação às cantinas: nasceram sob os auspícios de um atendimento profissional. Como as confeitarias elegantes, esses novos estabelecimentos ofereciam atendentes para servir os clientes, um elo de intermediação entre produção e consumo que não existia nas cantinas.

Era o início da profissionalização do restaurante. A família não seria mais o elo completo na cadeia de produção até o consumo, novos personagens seriam agregados em diversas funções para atender aos comensais. No salão, emergem os garçons, na cozinha as mulheres ainda conseguem ser reconhecidas, principalmente nas cantinas, mas perdem espaço à medida que surge o cozinheiro profissional, o chef.

Inicialmente, é preciso notar que os cozinheiros nem mesmo existiam nesse momento, os primeiros que se dizem como tal foram trazidos pelo pai de Aurélio Guzzoni, nos anos 1950. Em nada eram tributários à cozinha doméstica e feminina, ao contrário, valorizavam uma comida do norte (sua origem), dita refinada e transmitida sob novos padrões, receitas escritas e uso dos 
cardápios, nítido indicador de que se tratava de outro grupo, já que sabiam ler e escrever. Estas pelo fato de estarem legitimadas nos livros, com medidas e modos de preparo detalhados teriam maior autenticidade que o pobre repertório reproduzido pelas memórias das mammas.

Eram cozinhas que estabeleciam nítidos contrastes entre italianos e nesse momento não tinham quaisquer interesses em se unificar. A cozinha da velha guarda resguardava o papel feminino, a importância da família e do trabalho (não necessariamente nessa ordem) e mantinha uma relação nostálgica com a terra natal. Por outro lado, a cozinha dos restaurantes que serviam comida profissional, em geral do norte, se fortalecia como legitima pelo conhecimento adquirido, era uma comida feita pelas mãos masculinas, supostamente educadas e com ingredientes bastante diferentes da cozinha associada ao sul. Em alguns restaurantes trazia como destaque a polenta, praticamente desconhecida na cidade, o risoto ${ }^{131}$, o uso de manteiga e creme de leite, ingredientes presentes na cozinha do norte e amplamente difundidos pelos novos italianos que se dedicaram aos restaurantes. Na verdade, eram ingredientes associados à cozinha francesa, o que já lhes dava um status mais elevado pela fama que adquirida pela França adquiria nessa área ${ }^{132}$.

Esses ingredientes circulavam também ao lado de outros da cozinha do norte, como os frutos do mar, apesar de presentes na cozinha do sul, parece que houve predominância no uso de animais de criação, associados à origem rural e montanhosa de muitos imigrantes da primeira leva, especialmente o cabrito. Inclusive, como visto anteriormente, o fato de mexilhões e camarões serem “catados” pela população miserável às margens do Rio Tamanduateí já lhes concedia uma classificação menos favorável ${ }^{133}$.

Essa diferença está também marcada na origem dos novos italianos que provinham em sua maioria do norte da Itália e nesse momento já se destacava do sul como uma região mais desenvolvida economicamente. Nesse sentido, os italianos do sul eram vistos por estes italianos do norte como uma espécie de sub-representantes italianos, analfabetos e rústicos. Em comum, apenas o fato de compartilharem o gosto pelas massas e pelo pão, mas fora esse aspecto, as diferenças se faziam revelar constantemente, como o próprio Aurélio Guzzoni deixou entrever em vários momentos.

Entretanto, se as massas se prestam como ponto de convergência entre italianos, seus formatos, recheios e molhos denotarão as influências regionais, reforçando a dicotomia entre norte e sul que se fez presente nos restaurantes desse momento. A comida explicita a diferenciação

131 Prato feito com arroz, embora de um tipo diferente ao encontrado no Brasil e com técnicas de preparo em que se conserva o amido, desse modo, não pode ser levado, pois sua consistência é semelhante ao de uma papa.

132 Para o desenvolvimento dessa trajetória, consultar Mennell (1996).

133 Na verdade, me parece que o uso de frutos aquáticos estava ligado à pobreza extrema, uma vez que segundo apontou Pinto (1984) era comum que famílias miseráveis de imigrantes italianos e ex-escravos fossem juntas catar mariscos à beira do Tamanduateí e, possivelmente, essa prática tenha desaparecido das mesas como indicador de miséria. 
social bem como serve para a manipulação das estruturas de classe e diferenciação, nesse caso esclarecendo que cantinas e restaurantes italianos representavam mundos distintos.

Por outro lado, com as mudanças em torno do lazer urbano e das próprias dinâmicas das gerações de imigrante italianos, as cantinas ampliaram, sobretudo, a clientela servida. Alguns anos antes, a maioria dos consumidores eram homens, mas foi nos anos 1960 que a cantina assenta sua imagem familiar e explora seus sabores intensamente para além das fronteiras étnicas. Sua comida passa a ser referência de cozinha italiana na cidade, uma imagem que será apenas abalada a partir do recente fenômeno da globalização.

A cantina étnica recebe novos clientes, sendo então tomada como um lugar de lazer, de encontro entre gerações, de resgate de raízes. As mulheres menos presentes na produção, ainda conservaram parte de seu poder como detentoras de um conhecimento culinário específico e valorizado nesse contexto. O novo restaurante italiano também será um lugar de novas sociabilidades, mas abrirá suas mesas para além das fronteiras étnicas, trará o atendimento profissional e em alguns casos desaparecerá com a presença feminina na cozinha.

A cozinha italiana de cantina ganhou popularidade e avançou entre distintas camadas da cidade em função da facilidade pela qual pode ser preparada em casa, ampliando ainda mais o universo de comensais. Para tanto, a indústria teve ampla colaboração, pois conseguiu oferecer massas a preços módicos, estendendo o acesso desse produto de maneira mais ampla, o mesmo acontecendo com o molho de tomate. As receitas que compuseram o repertório da cantina não eram complicadas e de alguma maneira diziam respeito à macarronada que a mamma ou nonna serviam para a família, em geral aos domingos. Era uma comida que lembrava casa, família, mulheres e italianidade.

Macarrão e molho de tomate foram tomados como o principal prato da cozinha italiana ${ }^{134}$, mas na cidade de São Paulo ficaram estigmatizados como cozinha do sul, especialmente quando surgem os restaurantes servindo uma cozinha distinta, não necessariamente mais elaborada, porque de fato também tinha origens rústicas e rurais, mas marcava distanciamento entre grupos.

Nesse caso, derivados do leite marcavam um uso bastante diferente entre as cozinhas do norte e sul, bem como a utilização de frutos do mar, comum no sul e no norte, não foi reproduzida a principio com facilidade na capital paulista, ficando marcado também como cozinha do norte

134 Segundo Alexander (2000), Garibaldi quando libertou Nápoles em 1860 jurou que o macarrão seria a força unificadora da Itália, mas não o foi em sua categoria genérica, mas na forma do espaguete, este sim, o mais popular e mais flexível para ser produzido em larga escala. Molho de tomate tem uma trajetória mais conturbada, segundo o mesmo autor, teria surgido tanto em Siena nos anos 1560 introduzido pelos espanhóis, como também em Nápoles em 1596, como planta ornamental e mais tarde se transformou em comida de pobres como notou Capatti \& Montanari (1999). Molho de tomate, bem como a diacronia do serviço de mesa, foi incorporado no século XIX, uma prática que dizem ter sido introduzida na Sicilia e se assentou pelas mãos de Vincenzo Corrado (1734-1836) que escreveu o Il Cuoco Galante (O cozinheiro galante). 
nesse período. As caças eram comuns, e no norte costumava-se consumir muito javali, uma carne praticamente inexistente em São Paulo e que foi substituída pela carne bovina. $\mathrm{O}$ uso de carne era menos comum no sul, embora apreciada e o que não impediu a criação de um prato conhecido das cantinas que é o bife à parmegiana, feito com carne empanada, técnica que é também conhecida como à milanesa (à moda de Milão), embora sem molho de tomate e queijo ${ }^{135}$. Esse fato demonstra que há mais misturas do que se imagina nos cardápios. $\mathrm{Na}$ verdade, existia também, e bem menos evidente, uma diferença entre cozinhas próximas ao mar e das regiões rurais, bem como entre as cidades e o interior.

$\mathrm{O}$ formato das massas também variava bastante entre regiões, sendo que as massas recheadas (capelettis, raviólis e similares) eram mais comuns no centro e ao norte que no sul, onde se encontravam mais variedades de macarrão, mais finos, grossos, compridos etc. ${ }^{136}$. Nesse sentido, novas linguagens da cozinha italiana são incorporadas na capital paulista, desta vez tida como clássica e bem menos acessível que o tradicional macarrão com molho de tomate.

Em certo sentido, remete à dicotomia já apontada por Pereira (2003) quando descreve os perfis da italianidade no Brasil e descreve dois pólos que se confrontam, mas não deixam de se complementar, quer seja um perfil mais popular e outro mais elitista. Embora pareça que o autor se refere à diferenciação entre os imigrantes que foram para o interior e fazendas ante os outros que permaneceram nas cidades, essa oposição continua latente mesmo no meio urbano e demarca profundamente este momento dos italianos da capital paulista.

A dissolução das fronteiras regionais, especialmente na comida dos primeiros imigrantes sob a unificação do macarrão com molho de tomate, foi um caminho inicialmente trilhado para construir laços e vínculos entre membros de um grupo sem quaisquer envolvimentos prévios. Foi essa comida que se estendeu às cantinas e inaugurou o hábito de comer fora, ainda concentrado entre os homens italianos. Mas é a comida do norte e os novos restaurantes que irão inaugurar entre as camadas médias em formação o hábito de comer fora de casa.

A variedade de experiências imigratórias sofreu uma ruptura, embora ao longo das narrativas o fluxo do tempo não apareça de modo exato e tampouco essas disputas sejam evidenciadas de maneira nua e crua. Elas estão subjacentes em algumas memórias que tentam delimitar distâncias entre os próprios italianos. Um dos interlocutores foi muito categórico nesse sentido, "meu avô não era imigrante, ela já veio rico". Sincero ou não, o fato é que houve um esforço enorme em discernir suas origens com o intuito de criar o maior afastamento possível dos humildes imigrantes dos primeiros tempos.

Nesse caso, a afirmação foi tão contundente que levantou a suspeita, logo no começo da pesquisa, de que existiam desníveis internos entre imigrantes italianos, acionados em momentos

135 No Uruguai, onde nasci, o bife à permegiana é conhecido como milanesa a la napolitana, ou seja, carne empanada à moda de Milão, mas com queijo e tomate à moda de Nápoles.

136 Consultar mapas no Apêndice 4, fonte Alexander (2000). 
bastante convenientes. De qualquer maneira, tanto na fala desse interlocutor, como de outros em posições sociais mais favorecidas, tentou-se impor um distanciamento de classe, em que o étnico emerge como depreciativo, especialmente quando se relaciona à origem cuja diferenciação é amparada pela já quase clássica oposição entre norte e sul da Itália.

Essa dicotomia norte e sul na península itálica ocorreu de fato após a $2^{\underline{a}}$ guerra, quando a região norte tornou-se um expoente econômico e o sul amargava índices de subdesenvolvimento. Vale lembrar que essa ideia teve suas raízes moldadas em períodos anteriores, meados dos anos 1930, quando o sul é visto apenas como uma região colonial, embora sua população sempre interagisse com o capitalismo crescente que se disseminava pelo País e não necessariamente correspondesse a essa imagem de atraso, embora sempre associada à sua população.

A ideia de mamma e sul da Itália aparece normalmente colada nas falas dos entrevistados, especialmente aqueles de melhor posição social. Nesse caso, apesar de ambas as correntes terem acionado os vínculos familiares para encontrar meios para o sustento econômico, os papéis desempenhados pelos membros e, em especial a mulher, foram bastante distintos entre os fluxos de imigrantes analisados.

A família trabalhando em conjunto era uma forma básica de garantir o sustento, mas à medida que entra em cena a indústria, o homem passa a ser o principal sustento da casa, embora como foi visto, um processo em que ainda o trabalho feminino e infantil tinham lugar. De fato, a família como um núcleo essencialmente consumidor e não mais produtor surgiu a partir dos anos 1950 e inspirado no American Way of Life que se propalou nos anos posteriores ao fim do último conflito mundial.

$\mathrm{O}$ restaurante italiano que se contrapunha à cantina nem mesmo atendia os imigrantes da velha guarda e seus descendentes que pareciam não se identificar com essa comida. $\mathrm{Na}$ realidade, os novos estabelecimentos procuram se instalar nos locais de grande circulação de camadas privilegiadas, como o centro de São Paulo, ampliando o acesso e a oferta de novos sabores à sociedade local.

Outra interpretação pode ser extraída dessa relação, não somente uma distinção regional e de classe representada na comida, mas também uma questão que reverbera na autenticidade, no legítimo, pois os imigrantes e as suas gerações seguintes não seriam tão italianos como os integrantes das levas recentes. Envolve também a memória desse evento, cuja valorização ou não dependerá do lugar ocupado neste momento, pois anos mais tarde essa diferença de chegada no Brasil praticamente é anulada das falas dos interlocutores, ou pelo menos, perde importância para se ajustar ao imaginário mítico que se construiu em torno da imigração.

Para os primeiros imigrantes e seus descendentes ser europeu está associado à vinda e à colaboração ao cosmopolitismo da cidade, as novas levas já não percebem dessa maneira, uma vez que os regionalismos estavam sendo superados, ou pelo menos, acondicionados de maneira 
que se constituísse uma cozinha nacional e um sentimento de ser italiano. Se até então se era de Bari, da Calábria, Nápoles ou Puglia essa relação vai enfraquecendo enquanto filhos e netos se inserem na sociedade local e desejam ocupar uma posição diferente de seus pais e avôs.

$\mathrm{Na}$ verdade, os primeiros imigrantes eram para os novos italianos uma população pouco civilizada, de modo que precisavam ser domesticados e aproximados aos valores da Itália daquela época, já diluídos pelos anos de convívio em outro país. Cozinha italiana de cantina era rústica, doméstica e para o consumo masculino, portanto, farta. O novo se abria pelos restaurantes que surgiram praticando uma cozinha italiana relacionada a um grupo mais preparado, vindo em sua maioria do norte da Itália.

Não se anulavam por completo elementos da italianidade, mas seriam arranjados sob novas bases. Ser italiano vai ganhando força em detrimento do imigrante e se delineia uma nova fronteira, não são mais estrangeiros submissos, mas italianos que despontam no horizonte da cidade. Os laços de comunidade e bairro, normalmente regionais, serão substituídos por um sentimento mais difuso, embora ainda com vestígios étnicos.

Essa ambivalência não passa despercebida entre os interlocutores, os que possuem raízes nas cantinas enxergam a cozinha italiana que praticam como uma cozinha tradicional e de uma trajetória em particular. Contudo, as percepções vão se misturando, como notou Antonio Carlos Marino, proprietário do Restaurante Carlino, um dos mais antigos da cidade, "A identidade italiana consegue se manter, mas na comida tivemos muita mistura", ou seja, a ideia de nacionalidade começa a prevalecer sobre o étnico, imigrantes italianos, para se transformar em pertencimento à Itália, italianos. No plano social, a ideia de imigrante vai perdendo sentido à medida que começa a se constituir uma ideia de italiano. A cozinha já era localmente vista como italiana, mas começa a perder o ranço étnico e desfavorecido dos primeiros tempos frente à sociedade local.

A velha guarda apreciava a comida de cantina que, no entanto, causava certo estranhamento entre os italianos que chegavam nesse momento, pois não reconheciam a comida que se dizia italiana, ao menos no sentido que lhe era atribuído. Esse ponto era mencionado como uma espécie de susto que alguns interlocutores descreveram detalhadamente ao se darem conta da variedade de receitas e pratos que constituíam a cozinha italiana e apenas uma parte desse repertório era conhecido, tanto pelos italianos da velha guarda como os que chegavam mais recentemente. E a cozinha italiana praticada em restaurantes começava a incorporar pratos locais, especialmente os estabelecimentos que começavam a surgir no centro da cidade.

Antonio Carlos Marino, proprietário do Restaurante Carlino, considerado um dos mais antigos de São Paulo, enumerou uma série de itens ditos brasileiros no cardápio, outra novidade que diferenciava as cantinas e os restaurantes, além dos garçons como intermediários entre o comensal e a cozinha, bem como novos funcionários no preparo. Era servida a feijoada, o virado 
à paulista, o vatapá ao lado das massas, mas ele lembra que o "gosto pela comida italiana já estava assentado", como o dono anterior também comentava ${ }^{137}$. Na época, o restaurante ficava na região mais badalada de São Paulo, o centro da cidade, e foi nesse momento que passou para as mãos de Antonio Carlos Marino.

\begin{abstract}
O cardápio era fundamentalmente do norte da Itália: bom tomate, azeite de oliva e funghi secchi [...], tinham os pratos do dia e esses eram comida brasileira [...]. Servia-se muita vitela, cordeiro, tinha carnes recheadas, como o lagarto com espinafre, uma especialidade de Firenze [...] A nonna fazia o polpetone recheado de parmesão, eu faço de picanha [...] Veja bem, meu pai era açougueiro e não tinha condições de nos levar em restaurante, não tinha muito restaurante, e a vida era muito dura naquele tempo [...]. Eu fui autodidata, era pequeno e não tinha nada para fazer, minha mãe me ensinava a cozinhar [...] A Vieira de Carvalho foi a fase de ouro do Carlino, servia muitos clientes importantes, políticos, jogadores de futebol, artistas. Não tinha só a gente, tinha o Rubayat, o Dinho's, a Casa Ricardo, Dulca, Almanara, tudo desapareceu com a chegada dos gays.
\end{abstract}

Fora do circuito normalmente feito pelos italianos da velha guarda, o Restaurante Carlino foi também um espaço que vivenciou novas sociabilidades urbanas. Servindo cozinha de inspiração italiana, não deixou de incorporar novidades ao cardápio, especialmente pratos da cozinha local, sugerindo que era preciso contemplar paladares além do universo étnico. Durante anos funcionando em um ponto privilegiado, o restaurante começou a decair com a degradação do centro da capital paulista e os clientes começaram a sumir.

Por outro lado, a cozinha italiana estava caminhando para uma hibridação, tanto no que tange aos ingredientes e substituições, mas também com relação à flexibilidade dos cardápios que agora passavam a ter também opções de pratos locais. Menos que uma diferenciação entre cozinha do norte e do sul, o que estava sendo percebido era a ampliação do comer fora de casa circulando para além dos limites étnicos. Esse ponto também ficou claro nas memórias de outros interlocutores que percebem a diluição de frequentadores de origem exclusivamente étnica, embora muitos ainda italianos, uma classificação que também terá contornos mais genéricos aludindo à ideia de nação como elemento de coalizão.

Cozinha do norte como se pode ver era uma alusão para diferenciar origens e pertencimentos distintos no interior do grupo, mas a verdade é que já existia na cidade, representada em alguns restaurantes anteriores ao Ca'D'Oro que se diz o difusor dessa cozinha na cidade. Era uma cozinha que tentava reafirmar uma diferença de posição social, pois tanto o restaurante Carlino, como o Gigetto, este um ícone dos anos 1950 e 1960 da cidade, já tinham comida do norte sendo preparada em suas cozinhas. Na verdade, a separação entre cozinhas tinha um caráter

137 Antonio Carlos comprou o restaurante de Marcelo Luchesi que, infelizmente, não consegui localizar para este trabalho. 
muito mais direcionado de impor diferenças entre italianos do que de fato era percebido pelo público local.

Esse ponto é referido por Ana Paula Lenci, nora do proprietário do restaurante Gigetto. A diferenciação entre cozinha do norte e do sul seria uma pretensão, já que todos os restaurantes de alguma maneira já oferecem "cozinha italiana paulistana", o que na verdade não aconteceu nos anos 1950 e 1960. O que diferenciava as cantinas tradicionais, embora ela não fizesse alusão direta, era o tipo de clientela, bastante diferente daquela descrita nas primeiras cantinas e o tipo de atendimento, uma vez que alguns restaurantes ainda mantinham laços com uma administração familiar.

Além disso, entre os italianos mais recentes, as cantinas estariam servindo uma comida menos italiana, por assim dizer, uma vez que estaria distanciada de suas origens há mais tempo, provocando alterações que a deixariam menos verdadeira. A cozinha do norte seria mais italiana à medida que seu diálogo com a Itália era mais recente. São imagens que no fundo tentariam atestar as diferenças de posição social.

Reforça esse aspecto a narrativa da mesma entrevistada, ao descrever as pessoas que se sentavam à mesa dos restaurantes e, em especial, aqueles que abriram no centro da cidade, pois atraíam um novo segmento da população urbana, as camadas médias, e das quais muitos membros eram ligados ao universo cultural da cidade que congregava de tudo um pouco. Ana Paula contou que:

\footnotetext{
Era outro mundo, era um restaurante de 'emoção', criatividade e de amizade, o Plínio Marcos tinha uma mesa cativa, era o "escritório", todos eram conhecidos de todo mundo, começando que não tinha dinheiro e tudo era sem muito status. Era um espaço privilegiado, muito diferente [...]. Etty Fraser era frequentadora assídua, também vinha Glória Menezes e Tarcísio Meira, nos 55 anos da TV Brasileira a comemoração foi aqui. Vida Alves, da Fundação Os pioneiros, vinha aqui [...]. Joan Crawford veio almoçar aqui no dia da inauguração da fábrica da Pepsi, linda, tenho as fotos em algum lugar, mas se não achar deu em todos os jornais.
}

É fato que esses novos restaurantes italianos com temperos brasileiros atraíam uma clientela muito diferente, conforme Antonio Carlos e Ana Paula enfatizaram. Esse aspecto também é muito acentuado nas falas de Giovanni Bruno, que trabalhou anos no Gigetto como assistente de cozinha, assistente de salão e depois como garçom, reforçando esse sentimento em várias partes de seu depoimento. Era uma época de glamour, segundo Ana Paula, pontuada pela amizade, uma vez que "todo mundo se conhecia".

$\mathrm{Na}$ verdade, não era mais a sociabilidade étnica das primeiras cantinas, em grande parte formada pelos homens. Nesse momento, os restaurantes se abrem às mulheres, mesmo que ainda timidamente, sobretudo à noite, acompanhando a efervescência cultural daquele momento. A 
televisão e o teatro estavam cercados de interesse e muitos ainda eram pioneiros nessas áreas, fazendo fama, mas não fortuna. Contudo, era uma forma de atrair curiosos para o restaurante, interessados em acompanhar a vida de seus ídolos. Ainda existia um sentimento de proximidade que foi sendo diluído à medida que as dimensões populacionais da cidade e suas características a consolidaram como metrópole.

Giovanni Bruno lembrou que esse espaço era de fato uma convergência de um público altamente intelectualizado, muitos sem grandes recursos, artistas e jornalistas que saíam de suas atividades tarde da noite e desejavam comer algo antes de ir para casa. A cozinha italiana predominava no cardápio da casa, mas era possível criar alternativas que não estavam dispostas na lista para os comensais. Ele contou que,

\begin{abstract}
Bom, sentavam 10 ou 12 na mesa e avisavam, temos pouco dinheiro, em 1956 eu era cumim, em 1957 e 1958 fui promovido para garçom e minhas mesas eram divididas, pois eu preparava um contra-filé com uma porção de arroz bem farta e alimentava esse povo. Cuidava da dieta do Inácio de Loyola Brandão, cuidava de sua gastrite, aprendi um pouco a ser padre e médico [...] o restaurante é um ponto de encontro.
\end{abstract}

A relação de proximidade era evidente, assim como o restaurante era apropriado sob uma dinâmica bastante diferente. Primeiro estava fora do circuito étnico, por assim dizer, servia clientes variados, tinha cardápio e atendimento formal. Além disso, acompanhava a movimentação cultural, servindo comensais após os espetáculos, outro fator novo naquele momento. A cantina de comida étnica continuava viva, embora também se adaptando à nova realidade urbana e sem deixar de dialogar com os novos estabelecimentos. Vale apontar que ir ao restaurante tampouco era uma experiência ainda marcadamente individualizada como acontecerá nos anos de praças de alimentação. Ana Paula contou que

\footnotetext{
A vida dos artistas era difícil, era simples e precisavam se virar, quem vive do teatro tem uma vida muito 'certinha' e era assim, tinha um envolvimento que não era só comercial. [...] Era um grupo de sonhadores, idealistas, escreviam programas de rádio e depois para a $\mathrm{TV}$, as radionovelas, os programas. $\mathrm{O}$ cinema começando com Anselmo Duarte e que assinou o contrato do Pagador de Promessas aqui, a festa da Palma de Ouro foi aqui. Muitos discos foram lançados aqui.
}

O espaço público passava por novas apropriações, bem como a cidade fervia com uma vida cultural agitada e concentrada no centro da cidade, coração dos teatros, jornais, emissoras de rádio e televisão. Giovanni Bruno relatou algo semelhante:

Se você queria ver um artista era no Gigetto. TBC, Sérgio Cardoso, pessoas de grande porte. Dos anos 1954 a 1966 tudo passou pelo Gigetto, grandes prefeitos, grandes governadores. São Paulo na época tinha 2 ou 3 emissoras 
de radio. Tupi e depois Excelsior, o grande responsável foi Pedro Luís e na TV, Edson Leite. Depois veio a Rádio Bandeirantes, a rede Globo. [...] Aos domingos, sábados à noite, São Paulo era só centro, hoje se abriu como um leque.

Giovanni Bruno comentou também que o primeiro endereço do Gigetto na Rua Nestor Pestana é que permitiu arejar a cozinha italiana para novos comensais, já que a proximidade com o Teatro Cultura Artística, que depois passou a ocupar a TV Excelsior (o extinto canal 9), foi determinante para o sucesso do restaurante. "As noites fervilhavam de pessoas importantes e famosas", e o restaurante era o ponto de encontro dessa turma, como lembrou também Ana Paula Lenci.

A vida cultural e artística teve uma participação intensa na vida desses estabelecimentos e colaborou para difundir os restaurantes de cozinha italiana, embora sob um viés distinto daquele encontrado nas cantinas. Trocar refeições sem custo para os artistas pela divulgação dos restaurantes aos espectadores das peças foi uma prática amplamente difundida a partir do pioneiro Gigetto e, inclusive, foi o método adotado recentemente (anos 1990) por Walter Mancini, concorrente do restaurante na Rua Avanhandava.

O Gigetto se beneficiou da proximidade do Teatro Cultura Artística, inaugurado em 1950 e os restaurantes do Bixiga da proximidade com o Teatro Brasileiro de Comédia, aberto em 1948. Este último representou um grande avanço, uma vez que instituiu um corpo de atores e equipe técnica permanente, permitindo encenações constantes e bem montadas, tendo o mérito de transformar o empreendimento cultural em um investimento empresarial, iniciativa realizada por Francisco Zampari, seu fundador e bastante próximo do Conde Matarazzo para quem trabalhava como engenheiro. Nesse caso, o próprio Cicillo (como era conhecido o Conde) tinha interesse em apoiar essa nova execução interessado em agir como mecenas, uma forma de assimilar capital simbólico na disputa que marcava as relações sociais da época entre os velhos imigrantes enriquecidos e os "bem-nascidos" locais. O envolvimento com o setor cultural foi o caminho adotado para conquistar reconhecimento social.

Na verdade, o que se deve reter destas novas sociabilidades é que não se despem completamente de seu passado, mesmo porque os imigrantes que prosperaram buscavam pelo reconhecimento, mas não abandonavam por completo seus valores e práticas que necessariamente precisavam dialogar com uma carga expressiva de componentes locais. Os exemplos de famílias italianas que enriqueceram eram inspiradores de muitos imigrantes e seus descendentes, marcando, até mesmo, a presença desse grupo pela ação de membros enriquecidos da colônia que colaboravam como mecenas em vários espetáculos, além de incentivar pintores, escultores e terem tido grande envolvimento em construções importantes da cidade ${ }^{138}$.

138 Consultar Arruda (Op.Cit.) 
A participação de artistas, intelectuais, pessoas da área de comunicação teve um papel importante na formulação do comer fora de casa, até mesmo como uma prática associada ao lazer e ao ponto de encontro. Os espetáculos encenados nos anos 1950 e 1960 foram um estímulo à vida cultural, especialmente noturna e da qual alguns estabelecimentos conseguiram se aproveitar, nesse caso o próprio Gigetto e algumas cantinas do Bixiga, como lembrou Afonso Roperto.

Começava-se também uma troca de sabores, pois não raro algum cliente solicitava um prato em especial, cruzando etnias e classes. Assim, abria-se uma porta para uma nova percepção da cozinha italiana que saía de seus limites, alcançando novos comensais que nem sempre dispunham de grande capital econômico, mas contavam com bom capital simbólico.

Mas não se tratava de uma distinção meramente pela cozinha, pois era preciso além da formalização da refeição, incorporar técnicas de produção distanciadas da casa. E assim alguns dos novos restaurantes, os mais refinados, não hesitaram em associar técnicas da gastronomia francesa como padrão de alta gastronomia à cozinha praticada no norte da Itália ${ }^{139}$.

Nesse sentido, se retrocedermos ao século XVIII, novos arranjos em torno do alimento, como o início de um mercado de massa, a existência de monarquias e suas cortes, a constituição dos Estados nacionais etc. foram articulando as bases para o desenvolvimento de uma alta cozinha (haute cuisine) ${ }^{140}$ em oposição a uma cozinha popular, bem como outras definições (cozinha burguesa, cozinha regional, cozinha tradicional) que vieram a compor uma noção de gastronomia que foi mais tarde apropriada pelo turismo.

A palavra gastronomia ganhou visibilidade com Joseph Berchoux em $1801^{141}$, que usou esse nome para o título de um poema, o termo foi rapidamente associado, na França e Inglaterra, como "a arte e ciência do comer delicado", mesmo que em alguns momentos fosse utilizado como "julgamento do bem comer" ${ }^{142}$. De qualquer modo, inaugura-se um espaço antes inexistente à alimentação e firma-se um gênero literário específico a partir de obras pioneiras ${ }^{143}$.

É o modelo de alta gastronomia (haute cuisine) predominante na França que, passando por várias mudanças e em especial o movimento de nouvelle cuisine irá aportar em outras partes do

139 No jargão dos críticos gastronômicos, uma cozinha franco-italiana.

140 Termo derivado do francês, haute cuisine, um tipo de cozinha moldada sob condições pontuais em que ingredientes, técnicas e fama dos cozinheiros jogam um papel importante. Surgiu no fim do século XVIII, mas de fato se fortaleceu no século seguinte pelas mãos das novas classes sociais ascendentes na França pós-Revolução.

141 Poulain (2002) aponta que a disciplina gastronômica já possui alguma independência desde a metade do século XVII, em que se complicam os nomes de receitas e as maneiras à mesa e tendo aparecido bem antes em uma obra grega já perdida Arkhestratos: "gastronomie ou gastrologie”. Ver também Mennell (1996).

142 Traduções minhas.

143 Para uma análise detalhada e ampla, consultar Mennell (1996), especialmente a cisão entre a cozinha francesa e inglesa que, incrivelmente, compartilharam raízes muito similares, embora cada qual tenha tomado caminhos muito diferenciados, a francesa estabelecendo-se como alta gastronomia e a inglesa insípida e sem graça. Ver também DeCerteau (1998). 
mundo, disseminado pela facilidade com que as tarefas da cozinha são organizadas e distribuídas. Tratando a comida como arte e cada vez mais afastada do universo doméstico, o preparo seguia padrões e medidas exatos para não comprometer os sabores e poder ser reproduzido sempre. Além disso, salvo o chef e seu assistente, na cozinha ninguém mais sabia a ordem completa da receita, pois cada tarefa foi separada (lavagem, corte, preparo de saladas, molhos, grelhados e finalização).

A França, por exemplo, constitui uma noção de gastronomia para o mundo que tinha muito menos inspiração regional e muito mais amparo de inovações tanto técnicas como de receitas feitas pelos novos personagens, os chefs. Criou uma aura de reconhecimento, não pela cozinha real, mas pela cozinha ideal que foi forjada no início do século XX e que facilmente poderia viajar pelo mundo. Nesse sentido, para Revel (1996) seria essa a cozinha francesa que ficou difundida pelo mundo ${ }^{144}$.

Nesse sentido, a cozinha italiana que veio pelas mãos dos novos italianos era uma espécie de alta cozinha porque bebia da fonte da cozinha francesa, uma estratégia claramente adotada pelos pais de Aurélio Guzzoni (Fabrizio Guzzoni) e de Mario Tatini (Fabrizio Tatini), na época donos dos restaurantes considerados mais elegantes da cidade. O mesmo caminho parece ter sido tomado por Fabrizio Fasano quando retorna aos negócios de restaurante no fim dos anos 1980.

De qualquer maneira, estabelecer essa diferença entre cozinhas italianas, embora para os interlocutores tenha um caráter clássico, se valeu de uma noção de gastronomia forjada no fim do século XIX, amparada na cozinha profissional, na presença do chef, no uso de técnicas especiais, bem como ingredientes diferenciados para servir um público também distinto ${ }^{145}$. Devido à crescente urbanização, à consolidação de figuras como os chefs de cozinha e a proliferação de livros de cozinha e receitas, comer se transformou em alvo de interesse, sobretudo de camadas privilegiadas ansiosas por serem vistas de maneira distinta, conceito que adquiriu força e começou a se entranhar na vida cotidiana de classes favorecidas, especialmente urbanas.

Em ritmo contrário, foi também o momento em que as refeições familiares foram incrementadas, graças à introdução de novas informações, especialmente no quesito receitas, e equipamentos, permitindo ampliar o repertório de sabores. Dessa forma, a partir da sistematização

144 Um dos grandes nomes desse processo foi Auguste Escoffier (1847-1935) que delineou bem as características que dariam corpo à noção de gastronomia francesa. Nesse sentido, apesar de sua pouca experiência como autor, ele oscilou em sua cozinha entre adaptações da cozinha camponesa francesa e invenções. Nesta última categoria, surgiu a Taça Melba, uma sobremesa de sorvete, pêssegos e calda de frutas vermelhas, bem como os famosos crêpes suzettes (panquecas flambadas com licor de laranja) e que parecem ter nascido na cozinha praticada na França, mas foram novos pratos que emergiram no começo do século XX, mas que hoje são ditos clássicos.

145 Consultar Revel (1996). 
de um conhecimento que até então era transmitido de maneira parcial e oral, uma vez assentado e escrito, torna-se público e acessível incentivando um interesse renovado na alimentação que normalmente era bastante monótona.

E não se trata de um conhecimento exclusivamente doméstico, a partir dessa organização são também os conhecimentos dos chefs, de pratos de cozinha regional que irão formar um vasto conjunto de livros de receitas que terão maior circulação que a transmissão entre gerações do saber culinário. Esse fenômeno permite maior segurança na condução das receitas, há quantidade e discriminação dos ingredientes, bem como os procedimentos para sua execução.

Nesse sentido, o impacto de guias e roteiros também foi central, especialmente pela possibilidade de estabelecer uma classificação de cozinhas e consolidar uma noção de bom gosto, sobretudo entre classes sociais ávidas por se destacar. Esse estilo fundador é tributário a Grimod de la Reynière e seu Almanachs des Gourmands (1803 a 1812), inspiração até hoje para os guias de restaurantes contemporâneos. Ali era oferecido um rico panorama sobre a alimentação em uma publicação em formato de almanaque que desde seu primeiro número discutiu a qualidade dos produtos alimentícios mês a mês, posteriormente incorporando o "calendário nutritivo" de ingredientes. Trazia, também, indicações de cada pequeno comércio de alimentos existentes em Paris, além de comentar as mesas e os pratos dos restaurantes pela cidade ${ }^{146}$.

Dessa perspectiva, a gastronomia antes de representar uma evolução deve ser entendida como o resultado de uma série de condições presentes na sociedade que permitiram ao alimento e ao comer adquirir visibilidade e atenção. Na realidade, gastronomia é um produto cultural, com uma trajetória específica e uma dinâmica particular que permite ao homem se afastar da barbárie e incorporar características civilizadas ${ }^{147}$.

A cozinha praticada pelas mammas carecia de uma legitimidade dessa espécie e ainda tinha o fato de estar associada a uma classe de imigrantes considerada pior pelos italianos mais recentes. Sem o poder da palavra escrita ${ }^{148}$, as cantinas enfrentavam restaurantes com cozinhas organizadas em bases totalmente distintas, utilizando livros, proporções, técnicas, profissionais educados e treinados, além de buscar na cozinha francesa, elementos para reforçar sua distinção. É o que Aurélio Guzzoni definiu como uma cozinha clássica, que em seu caso tinha inspiração italiana.

Essa novidade causou espanto, como lembrou Aurélio Guzzoni de comentários de jornais da época, pois os comensais estavam acostumados com outro tipo de cozinha italiana, segundo ele comentou:

146 Outra referência do bom gosto é a obra de Brillat-Savarin (1995).

147 Revel (1996) vê a gastronomia como um aperfeiçoamento da alimentação, que passou pelo estágio da cozinha e alcançou um nível de especialização até então jamais visto. A comida, uma ação da cultura sobre o alimento, ganharia distância da natureza à medida que se essa transformação adquire maior complexidade. No limite, a gastronomia seria a reafirmação de nossa humanidade que encontra meios cada vez mais sofisticados de afastar-se da selvageria e da barbárie proporcionada pelo mundo natural.

148 A respeito dessa discussão sobre o poder de legitimidade da palavra escrita, consultar Silva (2000). 
Não tinham bons restaurantes italianos, meu pai introduziu uma cozinha do norte, com evidente influência francesa, com risotos, caças (aves) e cozido. [...] A cozinha quando ele chegou era mais do sul da Itália [...] as cantinas, dizia meu pai, era para glutões.

Glutões não sabem comer, ao menos da perspectiva proposta pela etiqueta da gastronomia ${ }^{149}$. Além disso, o descontrole frente à comida seria um indicador de ausência de civilização ${ }^{150}$, bem como a fartura não seria necessariamente uma indicação dessa boa educação. A cozinha praticada nas cantinas e associada ao sul não era comida para pessoas que tinham bom gosto, uma manipulação quase política para estabelecer o controle de quem é de dentro e quem é de fora em um ranking de distinção. $\mathrm{O}$ consumo de determinada cozinha italiana evidenciava o caráter relacional e ativo com o intuito de assentar identidades.

Mario Tatini, filho de Fabrizio e proprietários do Don Fabrizio, inaugurado em São Paulo nos idos dos anos 1950, contou em suas memórias (BARRETO, 2004) ${ }^{151}$ que:

Outros costumes gastronômicos foram anexados graças a uma atividade formadora de novos paladares, empreendida no Don Fabrizio. Até então, o paladar nacional não se coadunava com os escargots. Para criar um hábito alimentar, Mario começou a preparar Mariscos à bourguignone, uma invenção sua. [...] Ostras frescas foram também uma inovação introduzida pelo Don Fabrizio, bem como o linguado, peixe até então desprezado pelas boas cozinhas. Ou o molho rôti, completamente desconhecido até que Don Fabrizio começasse a prepará-lo. Virou base de molhos sérios, de restaurantes igualmente sérios. (2004, pp. 145 e 146)

Quanto à civilidade trazida pelo restaurante de sua família, Don Fabrizio, ele ainda complementou que

(....) a grande diferença que o Don Fabrizio trouxe à gastronomia brasileira foi uma profunda mudança de hábitos, observados não só nos restaurantes mas principalmente nas cozinhas domésticas. O formidável é que as mudanças foram sendo introduzidas de modo paulatino, até se perderem na memória, ora indicadas por uma prima, ora ensinadas pela vizinha. A fonte deixou de ser citada, como ocorre nos ditos populares. [...] Praticamente até a inauguração do primeiro Don Fabrizio, o conceito de cozinha italiana era, no Brasil, a de culinária do sul da Bota. Napolintana, baresa, siciliana.Havia também alguma influência veneta, com o uso intensivo da polenta, linguiça, passarinho, tradições presentes principalmente no sul do Brasil. Essa orientação brasileira

149 Ver Brillat-Savarin (1995).

150 Nesse sentido, Mennell (1996) distingue fome de apetite, pois ao controlar os ímpetos do comer, seríamos mais civilizados. A obra de Elias $(1993,1994)$ também é conduzida nesse sentido, uma vez que o autor lança um olhar provocativo nas regras de etiqueta analisadas em livros de boas maneiras, mostrando como foi a constituição da individualidade no comer, fruto de mudanças sociais e culturais mais amplas, mas claramente evidenciadas no comer.

151 Pelo que pude constatar, a família passava por um momento delicado de disputas entre netos e não havia disposição para conversas ou entrevistas. Desse modo, me lancei na pesquisa de suas memórias no livro citado. 
em direção ao sul da Itália se traduzia em molhos tonitruantes, afogueados, vermelhões. Com muita pimenta, muito alho, linguiça. Pratos, portanto, extremamente carregados. Não havia, por outro lado, a escola do molho alla crema. (2004, p.144)

Vale apontar que cozinha do norte da Itália, como qualquer outra cozinha regional, não é necessariamente refinada, mas se apóia na lógica de utilizar produtos que só podem ser encontrados localmente, ao menos de forma apropriada. Na realidade, os ingredientes usados nessa cozinha não eram tão inacessíveis, bem como as técnicas do cozinhar ${ }^{152}$. A questão está na associação desses ingredientes aos preceitos ditos clássicos da gastronomia francesa que nessa época era o principal guia de aspirantes à alta cozinha, deixando entrever as fissuras de um grupo que nada tinha de coeso.

\section{Restaurantes e famílias: a variedade da experiência étnica}

Frequentar lugares informais e próximos de casa foi ainda durante muito tempo um hábito cultivado pelos italianos nos bairros étnicos, como lembrou João Donato ao falar de seus frequentadores nos anos 1950 e 1960, embora também recebesse muitos artistas e jogadores de futebol, como faz questão de reforçar não só na fala, mas nas inúmeras fotos espalhadas pelo restaurante. Eram mesas grandes e muitas famílias, algumas já fora do bairro em função da prosperidade econômica, que retornavam para saborear os pratos que consideravam importantes como o macarrão com molho de tomate e frango capão, não só nos Castelões, mas também no Giggio, na Barila, na Cantina do Marinheiro entre muitas outras que funcionavam no Brás.

Os restaurantes italianos do centro, como o Gigetto, que se autodenomina cantina, embora esteja mais para restaurante ${ }^{153}$, era acompanhado lado a lado pelo Carlino, um restaurante que teve sua origem no Glicério, foi para o centro nas décadas de 1930 e 1940, servindo um público semelhante ao seu concorrente. Esses foram acompanhados pelos estabelecimentos elegantes que serviam comida italiana e clássica, como o Ca'd'Oro no centro, e Don Fabrizio e Fasano nas proximidades da Avenida Paulista.

152 Na verdade, carne de caça hoje adquiriu um valor distinto, pois é uma mercadoria que dificilmente se tem acesso na cidade, ao contrário do que acontece no campo. Na verdade, não é a cultura que determinava o cardápio, mas a natureza, uma vez que se ingeria o que se tinha conseguido caçar.

153 O Gigetto se diz a primeira cantina de São Paulo, mas em minha opinião, não pode ser entendido dessa forma, uma vez que reúne características mais próximas de um restaurante desde que foi inaugurado, existia uma cozinha familiar, mas o serviço não era feito integralmente pelos membros do núcleo e tampouco serviu exclusivamente membros da comunidade italiana. Persiste a dúvida, mas entendo como um bom caso de hibridismo. 
Segundo Afonso Roperto, essa distinção foi rotulada de imediato, inclusive pelos próprios donos de estabelecimentos. Muitos preferiram ser chamados de cantinas, servindo uma comida pouco elaborada, em muita quantidade com grande custo benefício, principalmente para as famílias. O restaurante ficou associado a um ambiente mais eclético, atendimento formal, alguns pratos italianos, mas também locais, sendo os mais refinados inspirados pelas técnicas francesas.

A disputa interna entre italianos se evidenciou na cozinha. Os velhos italianos e seus descendentes eram tidos como menos civilizados dada suas origens mais humildes, ao menos na opinião dos novos italianos que trouxeram ao universo urbano uma cozinha de fato italiana, do norte, técnica e profissional. Obviamente que em algum momento acabariam cruzando seus caminhos, mas nesse momento a separação estava dada.

Além disso, ninguém inventava receitas ou adaptava o que tinha à mão, como frisou Aurélio Guzzoni na forma de conduzir a cozinha de seu restaurante. O seu pai não gostava de mudar o cardápio, pois algumas receitas eram centenárias e não podiam ser mexidas. Reforça assim o caráter distintivo com relação ao trabalho empreendido pelas mammas, bem como procura legitimar as receitas utilizadas pelo uso de livros. Não que transformações não ocorressem, mas a ideia era "não mudar muito o cardápio", porque estava associado ao clássico, ao distinto e nesse caso, reforçando seu caráter educativo.

$\mathrm{Na}$ verdade, o arejamento da cozinha italiana que passou a circular fora dos limites étnicos foi um meio de expandir e seus sabores e aproximá-los da população local. Inclusive, muitos dos novos integrantes das camadas médias eram descendentes de italianos e tinham alguma proximidade com essa cozinha e ocupavam as novas posições de trabalho oferecidas pela cidade, especialmente em segmentos artísticos e culturais. E talvez tenham sido estes personagens que expandiram as fronteiras dessa cozinha, uma trajetória similar à observada por van Otterloo (2002) em Amsterdã com a cozinha asiática e a formação de um gosto pelo "exótico" entre os holandeses.

De qualquer forma, apesar de muitas cantinas continuarem a trabalhar em bairros associados à comunidade italiana, os comensais não eram mais exclusivamente italianos. Por outro lado, é importante notar que a cozinha italiana também contou com uma modalidade de circulação bastante forte nos anos 1950 e 1960 que foi estimulada pelas rotisserias, lojas que vendiam de tudo um pouco, mas em especial assados e massas.

Muitos interlocutores se referiram aos hábitos dessa época, lembrando que mais do que comer fora, era comum comprar refeições prontas e levá-las para casa, onde eram servidas à família. Argenzo, Spadoni, Donat's, Bolonha, Fasano, DiCunto foram as principais menções. Além dos assados, dos antepastos, algumas ofereciam doces, especialmente sorvetes, sendo um hábito comum passar no domingo pela manhã para encomendar e levar o almoço. 
Fabrizio Fasano oferecia esse tipo de serviço em seu restaurante instalado no Conjunto Nacional. Ele lembrou que na época (anos 1950 e 1960) nem existiam restaurantes que serviam almoço, as rotisserias eram muito procuradas e contou que para aumentar o faturamento, seu pai colocou mesas onde se podia tomar alguma coisa enquanto se esperava o pedido,

Domingos de manhã ali era o ponto de encontro, o pessoal sentava tomava um martini, em geral eram homens, e esperavam a entrega da comida, conversavam e quando pegavam o pedido, levavam para casa. Almoçar fora de casa era raro, ficou mais fácil com as cantinas, mas não eram lugares de qualidade [...] Sabe? Cozinha com cara de mamma, do sul, assim...

Comer fora não era um hábito comum, mas também se iniciava um acesso distinto à comida, permitido pelas lojas que forneciam refeições praticamente prontas. Contavam com uma clientela italiana, mas não deixavam de atender à população local que começou a frequentar e comprar seus pratos, em boa medida, como lembrou Fasano, porque aos domingos não se contava com a ajuda de auxiliares domésticos.

Era um cenário em que distintos planos teciam uma trama complexa em que a participação da cultura, política e geração passavam por confrontos quase irreconciliáveis. O caráter incompleto da italianidade se mostra então em várias facetas e nesse momento em especial é a própria maneira de se ver italiano e se pensar como brasileiro que emerge e se visualiza na cozinha italiana. Essa posição pode ter recrudescido o isolamento de alguns grupos e dado continuidade à cozinha de cantina como uma manifestação ante os novos personagens, afastando-se das inovações e abrindo um descompasso visível entre cozinhas italianas servidas em restaurantes.

Esse ponto também é relevante quando se aborda as gerações seguintes. Embora embebidos no discurso da velha guarda, é inegável que o arejamento trazido pelos novos imigrantes, especialmente aqueles com categorias profissionais inexistentes no Brasil permitiram o crescimento de distintas áreas de trabalho, em especial das artes, gastronomia, serviços de construção civil, atividades burocráticas.

Essas oscilações jamais foram resolvidas. A italianidade perpassava entre o rústico e o sofisticado, o erudito e o popular, o rural e o urbano, mas também transitava entre a nacionalidade italiana e a brasileira, tentativas que expunham as inúmeras estratégias para superar a dramática recepção e adaptação, quer fossem os primeiros imigrantes ou novos italianos vindos após o conflito mundial. Um objetivo era claro, não queriam mais ser "imigrantes" ${ }^{154}$, no entanto, não desejavam descartar totalmente sua trajetória e nessa tentativa, viam-se como italianos que trouxeram prosperidade à cidade, consolidavam sua nacionalidade, mas não abandonavam traços de sua italianidade que os distinguissem localmente quando necessário.

154 Algo semelhante é discutido por Pereira (2003). 
As percepções do ser italiano nos ofereceram nuances bastante diferenciadas nas memórias. Com ausências, disputas e posições foi possível entrever a pouca homogeneidade da comunidade italiana na cidade de São Paulo, apesar de toda a retórica em torno da saga imigrante. A cidade, o trabalho, a chegada, a família, a comida não se resumiam a um conjunto de traços plenamente discerníveis da italianidade e ao convívio pacífico, existiam rupturas bem mais duras do que aparentemente as memórias oferecem.

Essas desavenças entre italianos mostraram que o reconhecimento pela nacionalidade e a experiência imigratória vivenciada não tinham sentidos correlatos entre si, variando amplamente ${ }^{155}$. Esses conflitos não pareciam estar muito claros entre os habitantes locais, mas entre italianos antigos e novos, bem como seus descendentes. A comida foi um instrumento importante para revelar as descontinuidades que esse grupo enfrentava para se adaptar a um novo contexto.

Os restaurantes não ignoravam o peso das mudanças, se alguns manifestavam certo preciosismo no sentido de preservar receitas e técnicas, assumindo seu vínculo com a Itália, com a família e com as receitas da nonna, os anos 1950 testemunharam a chegada de novas linguagens gastronômicas, especialmente vindas pelas mãos dos italianos recentes, bem como presenciaram o hibridismo pelo qual essa cozinha passava. No entanto, não deixavam de reafirmar sua italianidade, especialmente pela preocupação em seguir receitas "centenárias".

E novamente parece que não se trata de um embate entre popular e culto, moderno e tradicional embora essas percepções perpassem de alguma maneira as falas dos interlocutores, principalmente entre os italianos do pós-guerra que acreditavam ser mais italianos que os locais. Por um lado, por terem ficado mais tempo na Itália e, portanto, um indicador de que sua italianidade era mais assentada que a dos imigrantes e seus descendentes, uma ambivalência que interpela o sentido da cultura italiana sem fronteiras pregada pelo regime fascista e latente nos anos pós-guerra e que de certa forma tentava se embrenhar pela comida.

As cantinas foram uma resposta às condições encontradas em determinado momento, mas com o declínio de uma estrutura social inspirada no café, a transferência de ideais rurais para outros urbanos formulou respostas para acompanhar o fluxo de novas dinâmicas, nem sempre suaves, mas certamente germinais para consolidar a ideia de uma metrópole cosmopolita. A comida italiana não rejeitou essas mudanças, mas seus padrões ainda estavam ativos, como o uso de molho de tomate, massas secas e queijo, a presença de sopas verduras.

E mesmo apregoando certa pureza em sua cozinha, os restaurantes italianos ditos elegantes não deixavam de dialogar com elementos locais. Colagens particulares surgiram para caracterizar

155 Di Leonardo (1984) analisou entre famílias italianas instaladas no sul da Califórnia a variedade da experiência étnica sob esses distintos prismas, mostrando que há desníveis surpreendentes com relação à percepção do trabalho, família, prosperidade, posição social. Algo semelhante foi apontado por Kosminsky (2007) em que analisou a ausência de um olhar de gênero na etnografia Italianos no mundo rural paulista, de Pereira (1974) e que poderia ter modificado algumas de suas análises. 
um tipo de cardápio bastante eclético, inspirado em pratos italianos, mas também com opções locais: feijoada, caipirinha, virado à paulista e ingredientes locais adaptados às receitas de fora. Além do hibridismo nas receitas, o que não implica mudanças estruturais imediatas, o mais elucidativo de novas linguagens é o fato de que essa culinária regional da Itália do norte ganhava distinção à medida que incorporava elementos da dita gastronomia francesa e os cardápios comentados da época refletem essa influência: filé com molho mostarda, filé sauce beárnaise e muitas sobremesas flambadas (submetidas ao calor por meio da combustão de alguma bebida alcoólica) como crepes suzettes fizeram dessa cozinha italiana do norte, de origem rústica e rural, adquir um novo status.

A trajetória de Mario Tatini é bastante elucidativa desse processo. Como tantos outros italianos que vieram após a $2^{\text {a }}$ Guerra, teve uma vida conturbada ao longo do conflito, saindo de Firenze, onde morava, para encontrar o pai que trabalhava e morava sozinho em Roma. Para ajudar a família, Mario então foi trabalhar em restaurantes, pois seu pai tinha deixado a esposa e os filhos em uma condição precária. Seu primeiro emprego foi como garçom no restaurante Giorge, atrás do Hotel Excelsior, conhecido por hospedar famosos. Ele permaneceu ali até 1951, quando seu pai recebe uma oferta de trabalho no Brasil e decidiu emigrar, buscando os filhos alguns anos depois.

Em 1953, a família toda vem para o Brasil e imediatamente fizeram arranjos por meio de um tio para arrendar um restaurante em Jundiaí, onde o pai e os quatro filhos (homens) ficaram encarregados. A irmã e a mãe apenas ajudavam eventualmente, pois não queriam que a mãe cozinhasse, embora tivesse grande conhecimento da cozinha do Vêneto, sua região de origem. Serviam fetuccine, peixe e frango a passarinho.

O negócio não foi para frente e o único retorno que conseguiram desse investimento foi receber como pagamento um velho restaurante em Santos. Sem outra oportunidade foram lá tentar a vida e a Cantina Don Fabrizio é aberta em julho de 1954. Até hoje Mario fala do susto que teve ao chamar o restaurante de cantina, já que ele e seu pai estavam acostumados aos requintados salões da Europa e não suportavam olhar para as garrafas penduradas pelos lustres, única forma de ajeitar o ambiente em um momento de pouca disponibilidade financeira. Os únicos bens preciosos (ou por eles considerados preciosos) foram os dois fogareiros, mais tarde chamados réchauds, trazidos da Itália na esperança de usá-los em algum empreendimento, obviamente de cunho elegante, já que permitiam o preparo dos pratos frente aos olhos do comensal, flambando diversos tipos de alimentos.

Mario Tatini se lembrava que ao iniciar as atividades do restaurante praticamente precisou buscar os clientes na rua, não entendiam os pratos e ninguém conhecia a técnica do flambado, já bastante popular na Europa e nos restaurantes em que ele trabalhara. Nesse sentido, o senso civilizatório aflorou e sua família decidiu ensinar aos locais como era um comer considerado 
de bom gosto, ao menos desde sua perspectiva. Para melhorar o quadro desolador do restaurante santista tiveram que lançar mãos de recursos que pudessem ajudá-los, embora não necessariamente do agrado deles, como foi o caso da decoração feita com "algumas garrafas de vinho para parecermos uma cantina", uma tentativa de se parecer com algo já conhecido e atrair clientes. Ele disse ainda que nem mesmo a cozinha italiana servida no restaurante era um registro conhecido dos comensais, pois o que eles conheciam como tal eram massas com muito molho de tomate e queijo por cima.

E Mario foi muito claro, não existiam ingredientes e nem clientela apta para diferenciar tal sofisticação. Na verdade,

\begin{abstract}
O inicio de um novo perfil gastronômico italiano, com criações próprias, coincidiu com a introdução de pratos clássicos muito solicitados na Europa, mas, até então, desconhecidos do paladar brasileiro, como Strogonoff, Steak à Diana, à Siberiana. E embora o Don Fabrizio utilizasse a versão canônica desses pratos, a fama internacional graças aos chefes franceses, alterou-lhes alguma que outra coisa para adaptá-los ao clima e aos organismos brasileiros. Em lugar do creme azedo, que poderia provocar indesejadas revoluções digestivas, ficou assentado que ele, aqui, seria substituído pelo creme de leite, fresco, puro e simples. Outras adaptações tiveram que ser feitas por inexistência de temperos e ervas. Sálvia, manjericão, estragão eram dificílimos de ser encontrados. [...] Champignon tampouco se encontrava por aqui: era importado da França, em latas, caríssimo. (BARRETO, 2004 p. 144)
\end{abstract}

Apesar dos obstáculos, conseguiram "prosperar" segundo seus padrões. O restaurante era estritamente familiar, pai e filhos trabalhavam juntos e cativaram boa clientela que vinha de São Paulo, motivada pela duplicação da via Anchieta. Diante disso, em 1958 inauguraram o Don Fabrizio em São Paulo, na Alameda Santos e foi ali que os fogareiros, sucesso em Santos, tiveram seu auge. Pratos que transitavam em sua origem italiana e francesa foram destaque: fetuccine al triplo burro, fetuccine all'Alfredo, filet mignon boîte, crepes Suzette, omelettes confiture. Além dos pratos tradicionais, introduziam novidades para agradar ao paladar local, recurso também comum entre outros interlocutores.

No entanto, se o restaurante chamava a atenção pela boa comida, não se pode ignorar um subterfúgio de grande impacto utilizado por Mario que já cultivava o gosto pela representação artística. Lançou-se como apresentador de programas de televisão, fazendo enorme sucesso entre donas-de-casa e auxiliares domésticas. Chegou a fazer cinco programas semanais em diversas emissoras, ensinando culinária e etiqueta.

Era a inauguração de uma nova fase, surgiam os espectadores e precisavam ser contemplados com programas para atender a distintos interesses. Nesse caso, o fato de Mario Tatini encontrar enorme recepção indica que novas sensibilidades estavam em circulação e os efeitos desse sucesso o faziam uma figura popular, bem como seu restaurante sentia os efeitos desse trabalho. 
A importância da televisão na divulgação de receitas e pratos, bem como orientações de etiqueta até então nunca se havia visto, em geral a tarefa de educar era empreendida pela família. Com esse maior acesso às informações, ser bem educado se transformou em uma preocupação, uma vez que as ideias de etiqueta circulavam com maior facilidade, sobretudo entre os novos espectadores de televisão. Como abrir o guardanapo, que talheres empregar para consumir determinado prato, como erguer um copo etc., gestos que demonstravam refinamento.

$\mathrm{Na}$ esteira desse sucesso, outros proprietários de restaurantes foram tentar sua sorte nas emissoras, como Giovanni Bruno e Antonio Carlos Marino, na esperança de impulsionar seus negócios. Davam entrevistas, receitas, orientações etc. em todo tipo de encontro na televisão que precisava atender a uma audiência interessada nessas novidades.

Mulheres assistiam aos programas e levavam os novos conhecimentos para a cozinha, creme de leite é incorporado ao cotidiano, assim como o macarrão que era apresentado em distintas versões, permitindo maior proximidade com mesas domésticas. Outra estratégia utilizada para divulgar restaurantes era tentar aparecer em notas de colunistas sociais da época, como a famosa cronista do jornal O Estado de São Paulo que assinava "Mary - go-round" em que laureava os melhores estabelecimentos noturnos da cidade. Sempre na lista dos melhores, Don Fabrizio acabou ficando como restaurante hors-concours e Mario ganhou o título de Mr.Personality.

Pouca importância teve o fato de que o cardápio desses restaurantes não fosse totalmente inspirado em receitas italianas, embora assim fossem classificados e alguns anos mais tarde alguns fossem deslocados para a categoria de comida internacional, um misto de sabores que transitava por distintas procedências com toques locais.

A ideia de educar o paladar, como contou Aurélio Guzzoni, era também um projeto de seu pai e fez que conquistasse um lugar diferenciado em uma cidade carente de gastronomia sofisticada. A cidade, segundo os interlocutores, ainda não tinha conhecimento suficiente para compreender o que era um comer apropriado e foi sua contribuição que fez que se plantassem as sementes do que seria mais tarde denominado de capital gastronômica.

Comer, então, seria um processo educativo e esse aspecto ficou muito claro nos relatos de Aurélio Guzzoni, bem como nas aulas de etiqueta que Mario Tatini dava em programas de televisão ao vivo. O restaurante como espaço das novas sensibilidades urbanas começava a se constituir em uma formidável vitrine e a cozinha italiana ganhava um novo olhar. Esses restaurantes eram espaços para as pessoas circularem, serem vistas e ver, mostrando um conhecimento em torno da cozinha que não se aplicava à humilde cozinha das mammas.

As cantinas fortaleceram suas características de estabelecimentos com comida caseira, farta, "sem frescura" como disse Ângelo Luisi. Se antes serviam aos paisani, lentamente suas mesas irão receber famílias, boa parte de descendentes de italianos, como atestou Giovanni Bruno, "muitos pais vieram com os filhos e estes espalharam o gosto pela comida italiana em 
São Paulo", fenômeno semelhante observado por outros interlocutores. A mesa do restaurante torna-se o centro da união familiar, sobretudo aos domingos, instaurando uma nova prática, especialmente a partir do fim dos anos 1960. O ambiente menos formal, mesas grandes, pratos que podiam ser divididos, preços ao alcance de orçamentos de famílias de camadas médias, estimularam a popularização da cozinha italiana.

A caracterização da cantina como restaurante da família neste período é evidente, "A cantina é o restaurante da família" afirmou categórico Adolfo Scardavelli, gerente da Cantina da Napoli, originalmente inaugurada em 1949 na Rua Maria Paula e nos anos 1950 transferida para a Rua Martinico Prado, onde está até hoje. "lugar onde você leva seu filho é lugar bom, é sinônimo de qualidade. Começar pelo tratamento, os filhos tem que ser bem atendidos [...] muitos conseguiram fazer restaurante por causa disso."

Ele representa a ambivalência de forma concreta. Os seus bisavôs vieram para o Brasil, sua mãe já nasceu em São Paulo e ele também. Curiosamente, ao conversar com ele nota-se um sotaque carregado com sons da língua italiana, podendo ser tomado por alguém nascido na Itália. Ao longo da conversa ele comentou em vários momentos que "me sinto mais italiano que muito nascido lá [...]", uma vez que essa característica seria decorrente de sua afinidade com o trabalho, "característica nossa, sabe? O italiano, o europeu de modo geral, gosta de trabalhar, não tem medo de trabalho".

Sua mãe praticamente o criou ali, pois desde que Antonio Buonerba, proprietário do restaurante, o transferiu para essa localização, ela ficou como cozinheira e completou mais de quarenta anos de atividades no mesmo local. Todas as receitas e o funcionamento da cozinha são de responsabilidade dela, embora a criação dos pratos, como o polpetone, tenha sido uma invenção em conjunto entre ela e Antonio, derivado de um prato napolitano que precisou ganhar novos ares para cair no gosto local.

Mas é fato que tanto nas cantinas como em restaurantes mais requintados foi necessário introduzir adaptações de receitas italianas, embora ficassem caracterizadas como cozinha italiana. Nesse sentido, apesar de marcar distintos momentos do fluxo imigratório, para o olhar de fora essa comida é assumida de maneira mais genérica como um emblema desse grupo, embora entre italianos os estranhamentos continuem existindo, como o próprio Adolfo demonstrou. Ele não se referiu a nenhuma pessoa ou restaurante em particular, mas a questão do trabalho, tão fortemente marcada nos anos 1950 e 1960, ainda é uma forma de delimitar pertencimentos, especialmente entre famílias que detinham uma condição menos favorecida e fizeram conquistas que lhes rendeu uma condição mais apropriada, segundo sua perspectiva.

A adaptação, segundo contou Adolfo, foi uma forma de complementar o cardápio do estabelecimento que era apenas composto por pizzas feitas pelo pai de Antonio em um forno atrás da casa em que moravam. Servidas aos vizinhos em mesas rústicas, sem pratos e talheres, 
o pai de Antonio oferecia o quitute aos amigos em suas horas vagas (era marceneiro), mas de tanto que ouviu dizer que tinha boa mão para a comida, decidiu abrir um espaço só para isso. Ele morava no Cambuci e conseguiu um ponto na Maria Paula, segundo Adolfo "um dos lugares mais finos da cidade na época". No começo era ele e sua esposa, Dona Ana Maria, que também cozinhava e preparava alguns outros pratos para complementar a oferta.

A família até hoje é responsável pelo restaurante, até mesmo os filhos de Antonio já começaram a participar mais ativamente das atividades do restaurante, tendo aberto alguns anos atrás uma pequena loja de produtos alimentícios, um empório localizado quase em frente ao restaurante e batizado de Giardino. O envolvimento familiar também aparece na condução e administração do restaurante, pois Adolfo e sua mãe são funcionários de confiança há anos trabalhando com eles. A origem imigrante e menos favorecida conduziu à família no sentido de valorizar o negócio e dar continuidade.

Nesse sentido, Adolfo se lembrou que com o correr dos anos, o lugar assumiu uma decoração com as cores da bandeira da Itália - branco, vermelho e verde - que também colorem o uniforme dos garçons. Garrafas penduradas, como nas antigas cantinas que se aproximavam mais a armazéns ou espécie de despensas, sugerem um ambiente informal, mas também apoiado em uma ideia de tradição, uma vez que as receitas são as mesmas desde o tempo de Dona Ana Maria passadas a Dona Leonor, mão de Adolfo, até hoje na responsável pela cozinha do restaurante.

Segundo Adolfo, hoje a clientela já não é mais de italianos como foi no começo e que Francisco costumava servir sem muito rebuscamento. Os comensais vêm de todos os lugares e vem se diversificando. As cantinas foram perdendo os paisani, mas ganhavam os filhos e netos que encontravam nas cantinas os sabores de casa, da nonna ou da mama. Em ambientes sem pretensões, com decoração semelhante à observada no Jardin di Napoli, comida farta, muito molho de tomate e queijo derretido, as cantinas foram lentamente incorporadas aos hábitos paulistanos.

Por outro lado, seguindo uma pista sugerida por Gabaccia (1998), que levantou um aspecto interessante ao analisar a difusão dos sabores étnicos em restaurantes na cidade de New York, A autora notou que no decorrer dos anos 1930 os restaurantes da cidade não se limitavam a servir comida étnica, mas diversão. Cantores que faziam espetáculos em restaurantes também não eram incomuns, como lembrou João Donato de Toni Tonini, um famoso cantor italiano que fazia a ronda pelas cantinas do Brás ${ }^{156}$. Ângelo Luisi também comentou que apreciava tocar seu bandolim, assim como o restaurante Fasano trazia atrações internacionais, como Nat King Cole. O restaurante não era somente um espaço para comer, era também um espaço para ver e ser visto, apreciar shows.

Nesse sentido, as linguagens que se multiplicavam permitiam também aos italianos vislumbrarem novas posições sociais e afastar-se do estigma de ser imigrante, embora em

156 Ele é também mencionado por Sesso Jr (1995). 
situações em que se precisa ressaltar essa imagem muitos interlocutores tenham lançado mão dessa estratégia. Valorizar os obstáculos e sua superação como forma de mostrar um sangue diferente que se sobrepõe aos nacionais e, inclusive, trazendo-lhes vantagens, embora em outras situações afirmem serem "brasileiros".

Esse lado da saga familiar foi comum entre vários interlocutores, vencer em um país estranho é uma fonte de regozijo, como reforçou em vários momentos Paola Tarallo, herdeira da Cantina e Pizzaria Speranza, cujos avôs e seu pai chegaram por volta dos anos 1950 à cidade. "Sabe tenho muito orgulho disso, eles chegaram aqui sem nada, não falavam português, nada e conseguiram chegar nisto aqui", pois hoje além da cantina original na Rua 13 de maio, possuem uma filial elegante no bairro de Moema. O resgate de passagens da vida de sua avó mostrou características por ela tidas como positivas: engenhosidade, tenacidade, disposição para o trabalho, autoridade e que, em parte, seriam derivadas do fato de "ser italiana". Mas em um novo contexto era necessário adaptar para conquistar.

Nesse sentido, Paola mostrou que o saber cozinhar aplicado à experiência de deslocamento e concretizado em um novo empreendimento, só poderia ter tido o alcance que teve devido ao trabalho e à união familiar. Além de contar, nos anos 1950 e 1960, com uma clientela já próxima dos sabores italianos, o que facilitou a introdução da pizza napolitana que, segundo a interlocutora, foi ideia de sua avó ${ }^{157}$.

Segundo Paola, sua avó foi a que trouxe as receitas, enquanto o resto da família ajudava em outras funções, como atendimento e administração. O principal da casa era a pizza napolitana servida à mesa, com pratos e talheres, ao menos na cantina da Rua 13 de maio, pois antes tiveram uma experiência no bairro do Morumbi onde vendiam pedaços de pizza para serem consumidas na rua. Quando começaram nesse primeiro lugar, a pizza era uma comida feita para ser consumida com as mãos, em pé ou andando. Tinha um caráter de comida de rua, que se tornou étnico quando foram para o Bixiga "lugar cheio de italianos" e a pizza pulou para o prato, servida à mesa ${ }^{158}$.

As distintas decisões tomadas sugerem que as dinâmicas desse momento estavam claras para os italianos que viviam essa experiência urbana. Speranza, apesar de compor o grupo que veio após a guerra, decidiu iniciar um negócio modesto e, percebendo a dinâmica das cantinas, procurou o Bixiga para levar seu empreendimento, "o público estava garantido", disse Paola, sua neta.

157 No próximo capítulo este assunto será retomado e será visto que a trajetória não foi bem essa.

158 Esse ponto ficou mais claro ao consultar Capatti (2001) em que descreve a popularização da pizza e foi justamente nesse momento. Algumas trattorias mais humildes começaram a servir a pizza sobre a mesa para ser consumida em pratos e com talheres, pois até então era uma comida de rua consumida com as mãos, embrulhada em um papel espesso. Fica a questão ainda pendente, mas é provável que esse acontecimento tenha ocorrido em São Paulo e talvez pelas mãos de Dona Speranza, que era de uma cidade próxima de Nápoles, berço da pizza, introduzindo uma nova experiência na cidade sem descartar seu repertório trazido de experiências de sua terra natal. 
O modelo da cantina passou a conviver com o restaurante refinado, proporcionando novos espaços para realizar refeições fora de casa. Contudo, a posição praticamente oposta entre esses dois modelos criou um espaço híbrido que reunia características de um e outro. Se antes nosso círculo era composto pelas cantinas, agora ele se abre em uma nova justaposição: cantinas convivem com restaurantes mais elegantes e, da junção destes, nasceu um modelo que reunia a comida de cantina e o atendimento dos restaurantes elegantes.

O Gigetto ${ }^{159}$ foi um exemplo claro de dinâmicas vividas nos 1950 e 1960. Eram restaurantes que se valiam do conhecimento das mammas, às vezes como cozinheiras, às vezes como fornecedoras de massas. Começaram a servir um público que nada tinha de étnico e começaram a circular nesses espaços pessoas como jogadores de futebol, artistas, políticos, empresários, evidenciando uma grande distância com o público que tradicionalmente afluía às cantinas, em especial homens. E serviam seus clientes por meio de garçons ${ }^{160}$. Eram restaurantes onde transitavam novas camadas médias da cidade, em parte composta por descendentes de imigrantes que ocupavam novas profissões, mas nem sempre detentores de capital econômico.

O centro era a convergência dessas novas sensibilidades urbanas, como lembrou Aurélio Guzzoni quando seu pai decidiu abrir o hotel e o restaurante nessa região. Inaugurado em 1953, seguiram uma tendência dos novos italianos, buscaram atividades bem distintas dos imigrantes anteriores, demarcando sua diferença a partir de seu capital intelectual.

Os novos restaurantes refinados surgiam dialogando com a velha guarda, as cantinas. Era o confronto entre forças civilizatórias de distintos calibres atuando sobre a população local, carente de educação gastronômica. Era o início da alta gastronomia em São Paulo, mas ainda enfrentando dificuldades para ser aceita, inclusive entre "as pessoas importantes, que achavam que aquilo que fazíamos não era cozinha italiana”, contou Aurélio Guzzoni e corroborado pelas percepções de Mario Tatini.

Por outro lado, as cantinas continuaram em sua mesma linha, servindo macarrão com molho de tomate e assentando sua imagem de comida de imigrantes da velha guarda, pelo menos ante os italianos mais recentes. Já os restaurantes mais refinados ofereciam pratos que não necessariamente caíram no gosto dos antigos imigrantes, mas serviram para atrair membros de camadas privilegiadas. Nesse contexto, a ideia de educar o paladar desses frequentadores foi uma referência comum, e mais do que isso, esses espaços foram tomados como espaços de distinção ${ }^{161}$.

Era um período de várias transformações e os restaurantes não passaram ao largo dessas mudanças, bem como a cozinha italiana não ignorou a necessidade de organizar novos arranjos

159 Nesse caso, o Carlino também poderia ser classificado nessa categoria.

160 Neste caso, consultar Warde \& Martens (2000) sobre essa relação em restaurantes e o medo de ser atendido de maneira desagradável.

161 Para uma análise desse aspecto em restaurantes, consultar Finkelstein (1989). 
para indicar como era pensado o italiano em São Paulo. Aliando-se novos sabores, paladares abertos, outros fechados e a incipiente influência da mídia e meios de comunicação, distintas italianidades ficavam mais expostas, embora não totalmente descoladas entre $\mathrm{s}^{162}$. A Itália expulsou filhos que viveram diferentes ritmos e estes criaram trajetórias particulares para falar dessa experiência, a imigração pode ter sido o ponto de partida, mas os italianos acentuaram suas diferenças em função das trajetórias de vida que marcaram as distintas levas.

Nesse caso, um novo elemento é anexado, a questão da mobilidade social que não deixa de estar associada também ao imaginário de italianidade e às diferentes aspirações dessas famílias, uma vez que segundo o lugar social ocupado, a noção de sucesso mostrará ser bastante flexível. Em função da ideia de permanecer ou não em solo paulistano, o acumulo de capital terá diferenças orientações, bem como o trabalho empreendido.

Contudo, além das diferenças com relação ao fluxo de chegada, existiam também diferentes articulações com relação à situação social e econômica da família, delineando percepções particulares. Para os menos prósperos ou que tinham passado por maiores dificuldades, o pai educou para "uma boa vida, honesta, de trabalho", valores que são parte das "famílias italianas". Em parte, era também o que se permitiam esperar de uma situação pouco confortável, especialmente entre italianos da velha guarda que precisavam engrandecer sua luta contra a pobreza, o sacrifício, o esforço e repassavam esses sentidos aos filhos.

Para os mais prósperos essa referência já não se mostra tão clara: o trabalho é importante, a manutenção do negócio familiar não é tão central e perde espaço a ideia de sacrifício, a não ser quando as condições iniciais tenham sido complicadas, como no caso da família Tatini, mas muito menos evidentes nas falas das famílias Guzzoni e Fasano. Os pais permitem que os filhos tenham sua vida, "mas que não esqueçam dos negócios da família”, uma preocupação que é repassada às novas gerações com grande insistência.

Avariedade das experiências familiares e diferentes atuações na condução dos estabelecimentos se percebem no empenho com que os herdeiros se colocam ante o negócio. Nas cantinas a transmissão da propriedade é, preferencialmente, feita aos filhos homens, quando muito as mulheres dividem um espaço que nem sempre é expressivo na medida em que esperam. Nos restaurantes mais refinados esse princípio também é observado e vale o mesmo para as mulheres, nem sempre há um lugar para elas, às vezes tendo primazia os genros ao invés das filhas.

$\mathrm{Na}$ verdade, o que foi possível entrever nas memórias foi que as expectativas depositadas sobre as novas gerações estão sob orientações diversas. Nas famílias menos prósperas, os entrevistados mostraram preocupação com os estudos, em geral uma preocupação dos pais para com o futuro dos filhos naturalmente destinados a assumir o negócio futuramente. O estudo é

162 Como observou LaCecla (2007) em seu trabalho sobre a relação dai italianidade e comida, “nós somos o que comemos, mas também comemos o que somos". Por isso, o jogo não se esgota em uma oposição, mas em uma constante reavaliação do imaginário e da prática. 
um ganho simbólico para toda a família e um caminho para sedimentar o trabalho das gerações anteriores.

Entre as famílias com melhores condições, espera-se que os filhos permaneçam no empreendimento, mas não limitam as opções dos filhos caso queiram seguir seu próprio caminho. Nesse caso, foi curioso perceber uma trajetória comum entre interlocutores que tiveram filhos que fizeram esse percurso, mas também pais que deixaram seus filhos tentarem trilhar um caminho individual, embora com o correr dos anos muitos tivessem voltado para suas origens, ou seja, ao negócio familiar. Neste último caso, estavam Afonso Roperto, Fabrizio Fasano e Aurélio Guzzoni que fizeram carreira em áreas totalmente diferentes dos pais e à medida que envelheciam, sentiram necessidade de retomar as rédeas dos estabelecimentos.

Passar os negócios para os filhos ou receber essa responsabilidades dos pais é um momento cuja percepção é bastante tensa. A preocupação em continuar, mudar ou não ter condições de levar adiante é constante, mas aqueles que podem preferem que o estabelecimento permaneça em mãos familiares. Poucos foram os casos que essa negociação não se observou, inclusive com muito mais vigor quando o restaurante já conta uns bons anos de atuação. As mulheres praticamente não são mencionadas.

É curioso, no entanto, perceber que apesar desse apagar da presença feminina nas cozinhas das cantinas, elas ainda são mencionadas com frequência como bastiões da tradição, da família e da boa comida. Circunscritas ao universo doméstico ainda exercem poder, como deixou entrever Afonso Roperto ao descrever o processo para introduzir um prato de massas com molho de cogumelos secos (funghi secchi). O prato passou pela aprovação de várias mulheres da família, até chegar à nonna, cujo poder de aceitar ou rejeitar uma novidade não é discutido, apenas é aceito.

O mesmo não se observou nos restaurantes de cozinha italiana refinada, onde as mulheres nunca tiveram uma participação expressiva na cozinha e se limitaram aos afazeres domésticos, embora seu conhecimento fosse aludido de maneira positiva, faltava-lhe adequação para o universo da cozinha comercial.

Nesse sentido, as receitas também não eram um ponto de entendimento, para muitos era preciso manter certa fidelidade quer fosse advinda do conhecimento feminino, como nas cantinas; quer fosse do conhecimento profissional, no caso dos restaurantes. Na verdade, era uma tentativa de se aproximar de uma cozinha imaginada como real na terra natal, mas nem sempre ao alcance no novo contexto. Mario Tatini em suas memórias descreveu:

O Fetuccine à Moschettiera, criado como uma variação do Amatriciana - que leva cebola, bacon e tomate -, é preparado com bacon, champignon e tomate. A reunião da intensidade do bacon com a delicadeza do champignon também provoca estranhamento. Mas, no extremo desse crescendo de sabores fica o Paglia e fineo à marechiaro, criado também por Athos (irmão de Mario), 
que culmina ao acrescentar, à receita anterior, as ostras. (....) Os pratos não são inventados, mas criados, adaptados a um costume ou fantasia, como a vontade de comer alguma coisa diferente. Eles existem seja na geografia, seja na história. Real ou imaginária. A tarefa, portanto, é trazê-los à vida, dar-lhes corpo, de acordo com o desejo. (BARRETO, 2004 p.147)

A introdução da novidade, portanto, existia, mas seguia uma liturgia própria. Outra forma de criar novos pratos era atender algum cliente que voltava de viagem e desejava reproduzir algo consumido em seu passeio, como Mario disse ter feito várias vezes. Esse processo também foi mencionado por Giovanni Bruno ao criar o Capeletti à romanesca, quando ainda trabalhava no Gigetto, combinando uma massa recheada com molho à base de creme de leite, ervilha, presunto e palmito, este último um ingrediente de sua cabeça. Aurélio já era menos direto quanto às adaptações embora fossem evidentes quando contou que seu pai foi o responsável por introduzir a caipirinha antes da feijoada, pois "era bebida de pinguço, servida em botequim, não era nada disso", contou.

No plano do consumo, era a abertura de novos acessos a sabores que antes circulavam de maneira limitada pelos interstícios étnicos e os novos imigrantes que importavam técnicas e cozinheiros dedicados a uma gastronomia desconhecida na capital paulista. No plano da produção de comida vários fatores se uniram para transformar o trabalho na cozinha.

Afonso contou com certo orgulho que admirava sua avó, pois a maioria das receitas feitas na cantina atualmente veio com ela, "em sua cabeça". Com as coisas caminhando bem, ele disse que sua mãe "não precisou ficar na cantina, nem na cozinha, nem no salão". Esse processo não foi exclusivo em seu estabelecimento e nas gerações seguintes se transformou em uma ajuda eventual.

Esse fenômeno ocorreu em outras cantinas. Em 1953, a napolitana Speranza que iniciou sua pizzaria, foi deixando os negócios com o marido e com o filho, embora supervisionasse a cozinha com alguma frequência, fato que já não se deu na geração seguinte. Nesse caso, a maioria dos funcionários era nordestina, especialmente os pizzaiolos (que fazem a pizza). Seu filho ficou encarregado da supervisão e os netos ficariam mais tarde responsáveis pela expansão da cantina e pizzaria.

A distância com a cozinha do "norte", na maioria dos casos, ficou evidente. Como esse tipo de comida era servido em restaurantes ditos mais refinados, a produção raramente passava pelas mãos femininas. As mammas ficaram responsáveis pela introdução de uma cozinha italiana de má qualidade, segundo comentou Fasano, em que o étnico é posto à distância entre imigrantes recentes e de melhor posição social. É uma crítica à falta de abertura dos italianos da velha guarda, bem como seus filhos, ao contrário dos novos italianos que em contrapartida na época eram vistos pelos mais antigos como "preguiçosos", denotando uma desigualdade evidente com relação ao que se considerava trabalho. 
E nesse caso, o trabalho feminino não é considerado apropriado na esfera do comer público, ou pelo menos, não trazia prestígio à comida e ao estabelecimento, na opinião dos que pertenciam aos fluxos de italianos mais recentes e que olhavam as cantinas com certo desdém. Para os que apreciavam as cantinas, ali estava o referencial de comida italiana.

As mulheres, infelizmente, ficaram presas a essa percepção menos apropriada da cozinha italiana, ao menos ante os que dizem saber entender de cozinha italiana. Para os novos atores essa influência na comida a deixava com menos valor, pois suas mulheres não precisavam "trabalhar fora para sustentar a família" como disse Fabrizio Fasano com alguma ironia.

A cantina permanecia firme à herança familiar, os restaurantes mais requintados contavam com a família, mas não integralmente, pois as mulheres já não eram consideradas um fator diferencial para o empreendimento. Novos objetivos permeiam a família, bem como novas práticas darão status às camadas médias que se formavam na cidade dos anos 1950 e 1960.

É claro que algumas situações denotam ambivalência como a própria trajetória do Gigetto, com um pé no mundo da cantina ao manter a produção em mãos femininas, mães dos sócios, e outro na esfera mais requintada porque oferecia uma decoração mais apropriada junto a um bom serviço. No entanto, esse conhecimento não foi passado à família, mas aos novos personagens da cozinha, os nordestinos que foram substituindo os braços familiares.

Esse cenário em nada se aproxima dos restaurantes mais sofisticados, onde a mulher estava completamente afastada das atividades públicas. Esse ponto ficou muito claro nas falas de Fabrizio Fasano, desdenhando a influência das mulheres na cozinha da capital paulista,

\begin{abstract}
Fica essa comida de cantina, sem qualidade, com cara de casa, de comida da mamma [...] Eu não sirvo isso em meus restaurantes, minha cozinha é de chef, com os melhores ingredientes, trufas brancas, azeites importados, nada dessa coisa que a gente vê por aí nessas cantinas. Basta ver as cantinas que dizem servir comida italiana apelando para essa coisa da mamma, da mulher na cozinha [...] que acabou fazendo uma comida com molho de tomate curtido, pesado e cheio de queijo gratinado, ao contrário da cozinha profissional, com pratos e sabores elaborados e nem tão pesados, muitas vezes leves, mas que indicam que os ingredientes são frescos, que o chef é profissional.
\end{abstract}

Cozinhar demais a comida, ao que parece na fala do interlocutor, é uma forma de mascarar a comida de cunho inferior. Nesse caso, ao cozinhar demais os molhos e usar queijo gratinado seriam subterfúgios típicos de quem lida com recursos escassos e precisa encontrar meios de melhorar o sabor e o aspecto da comida. Mammas reúnem tudo que o interlocutor mais abomina: pobreza, dificuldade, sul da Itália como região atrasada (ele disse que era de Milão, dínamo econômico da Itália).

Até mesmo a forma como encarar o lar é distinta entre as famílias: as mulheres que trabalhavam em cantinas ao ficar em casa terão um merecido descanso, embora quando solicitadas estejam 
disponíveis e sua opinião seja considerada importante. Para aquelas cuja família é proprietária de restaurantes mais refinados, a condição normal era ficar em casa para cuidar de suas tarefas.

A família como núcleo econômico que produz para si e para fora, terá um novo papel. Ela será predominantemente consumidora e as mulheres não terão a participação ativa que até então praticavam. Os nordestinos se tornaram os novos personagens da cozinha, "Nos anos 1950 a cidade não tinha mais de 10 restaurantes", contou Giovanni Bruno, "começaram a chegar os nordestinos e se adaptaram muito bem, veja o Lellis" (Francisco Lellis, dono de uma cantina que leva seu nome no bairro dos Jardins). São Paulo ainda tinha o gosto de uma cozinha do sul da Itália, o Gigetto era uma cozinha do norte (Lucca, aliás, como o Carlino de onde nasceu o Gigetto), sem mencionar a qualidade daquilo que era servido, mas enfatizando a possibilidade de versões da cozinha italiana.

Os regionalismos ainda estavam circulando, mas agora dialogando localmente, abrangendo uma dicotomia entre norte e sul, civilizado e rústico. É um momento em que a diversidade também penetra na cozinha, jamais hermética, mas profundamente arraigada na busca de um reconhecimento étnico que começava incorporar noções mais amplas de nação.

Mas o fato é que estes novos funcionários contavam com uma remuneração, mesmo que modesta e que raramente chegou às mãos das muitas mulheres que participaram ativamente das atividades das primeiras cantinas. O desnível é evidente na valorização do trabalho feminino, desclassificado pelo fato de ser um conhecimento transmitido oralmente e do universo doméstico. Além disso, o atendimento deixou de ser feito pelo marido e filhos. Novos personagens, os garçons, emergem com força criando novas relações entre cliente e restaurante.

Essas distintas experiências evidentemente poderiam ser desenvolvidas à luz de outras questões, mas tomando a cozinha como um espaço social em que se reproduzem algumas relações sociais que evidenciam a desigualdade, é possível entrever algumas estratégias que demarcam profundas diferenças na mesma cozinha italiana.

\section{A cozinha italiana, mudanças e formação de identidades}

As transformações em uma cozinha não necessariamente denotam um giro nas estruturas do comer, mesmo que o grupo esteja sob profundo movimento social, fato que Goody (1982) notou ao traçar um paralelo entre esses dois pontos. Talvez houvesse sido interessante conseguir acessar cardápios de restaurantes da época, mas as cantinas não costumavam oferecer nada escrito, assim como entre os estabelecimentos mais refinados, os interlocutores tenham dito que não guardaram nada sobre esse assunto. 
$\mathrm{Na}$ verdade, seria uma forma de compreender como os pratos se distribuíam em uma sequência, o que compunha a ideia de entrada, prato principal e sobremesa. Além disso, como era o trânsito entre o que a casa oferecia e como, frente às narrativas, se colocavam pratos e pedidos especiais feitos pelos clientes. Na verdade, é inegável que os novos restaurantes e suas transformações estão associados ao movimento social mais amplo, fato que Capatti \& Montanari (1999) observaram também ao analisar a história da cozinha italiana e os modelos de restaurantes encontrados na Itália e suas trajetórias ao longo do tempo.

No entanto, quer fossem mais populares ou refinados, os cardápios não foram encontrados, os entrevistados lembravam somente das mudanças nos hábitos dos comensais por volta do fim dos anos 1950 e início dos 1960 que começavam a procurar restaurantes para almoçar fora e os restaurantes começaram a oferecer pratos do dia, um costume que se difundiu rapidamente entre os estabelecimentos de cozinha italiana.

Segundo os interlocutores tampouco era comum abrir na hora do almoço, pois era hábito ainda comer em casa nesse período e só mudou no fim dos anos 1960, embora abrissem para almoço aos domingos, eventualmente sábados. O funcionamento para essa refeição foi sendo moldado à medida que a cidade crescia e os deslocamentos foram ficando mais lentos em função do trânsito. Nesse sentido, alguns estabelecimentos começaram a oferecer o prato do dia, uma proposta diferente em cada dia da semana destinada ao comensal mais apressado com necessidade de se alimentar fora de casa.

Nos anos 1960 e 1970 ainda não existiam os restaurantes de comida por peso, os "quilos" 163 , e almoçar fora de casa começava a ser uma prática recorrente. Ana Paula Lenci comentou que o Gigetto começou oferecer, no fim dos anos 1960, opções diárias para o almoço e especialmente pensando nas pessoas que deveriam voltar ao trabalho.

Os pratos servidos eram os seguintes:

$$
\begin{aligned}
& 2^{\mathrm{a}} \text { feira - galeto e cotechino com lentilha } \\
& 3^{\text {a }} \text { feira - rabada } \\
& 4^{\text {a }} \text { feira - dobradinha } \\
& 5^{\mathrm{a}} \text { feira-ossobuco } \\
& 6^{\mathrm{a}} \text { feira - mariscos à provençal }
\end{aligned}
$$

Sábado e domingo o serviço era feito à la carte, ou seja sem sugestões do dia, e lembrou que era também uma opção disponível para o cliente quando não quisesse escolher a sugestão do dia. Serviam também testículos de galo, miolo e rins. Coelho e frango com farofa eram pratos de sábado e domingo, "saíam muito, ao lado de bife à parmegiana e as massas", disse ela.

163 Para a trajetória desses estabelecimentos, consultar Abdala (2003). 
Namorado à brasileira com molho acebolado, pirão e camarão era outro prato com grande procura e não mais no cardápio, assim como todas as saladas com maionese, especialmente a de atum. Além dos miúdos, tradicionalmente presente à mesa toscana e que inspiraram a cozinha do Gigetto, esses pratos eram os que saíam com maior frequência, além das massas que sempre tinham clientela cativa.

É interessante notar que o uso de miúdos era uma forma de utilizar até o último recurso dos animais, um costume comum utilizado na área rural especialmente quando era feito o abate de algum animal, como comentou Ângelo Luisi. Era uma forma de garantir comida à mesa por mais tempo, pois em geral eram feitos chouriços e linguiças que durassem alguns meses.

Esse tipo de preocupação com os recursos não se mostra somente na cozinha do sul da Itália, a cozinha do norte dos novos restaurantes também não ignorava a importância do uso dos vários produtos do animal. Na verdade, essas partes foram perdendo importância à medida que outras carnes foram consideradas mais apropriadas para o consumo, perdendo valor e, em muitos casos, nem mais chegando ao consumidor final, pois boa parte seria aproveitada pela indústria para a fabricação de produtos como salsichas, hambúrgueres entre outros.

Curiosamente a cozinha do norte dita sofisticada pelos seus produtores também se valia desses ingredientes, uma vez que sua origem também era rural e doméstica. A questão é o que essa comida representava nas articulações entre os distintos grupos que se encontraram em São Paulo, cujas extensões atravessavam o Atlântico e se expressavam publicamente na cozinha dos restaurantes, estabelecendo diferenças entre grupos. Alguns exemplos podem ajudar a visualizar esse ponto, uma vez que quase todos os restaurantes, mais sofisticados e menos, serviam carnes hoje consideradas como de segunda classe.

Os pratos do dia servidos em restaurantes refinados como Ca'd'Oro, foram assim elencados por Aurélio Guzzoni:

2- feira - rabada com polenta

$3^{\text {a }}$ feira - dobradinha

4. feira - coelho com polenta

5- feira - risoto à milanesa com ossobuco

6 feira - bacalhau com polenta

No caso específico deste estabelecimento, a diferença que emerge com relação aos restaurantes do sul é o uso da polenta, muito mais difundida no norte da Itália e mais conhecida no sul do Brasil pela vasta influência veneta. Esse prato veio pelas mãos de italianos que vieram no fim do século XIX e foram para os estados do Rio Grande do Sul, Santa Catarina, Paraná e interior de 
São Paulo ${ }^{164}$. E apesar de toda retórica em torno da sofisticação, a polenta é um prato camponês e fundamental na alimentação rural, de modo que sua presença surpreende em um restaurante que se disse à época "o mais elegante de São Paulo".

No sul da Itália há predominância do cabrito, animal que se adapta bem ao relevo local montanhoso e pedregoso - e o amplo emprego do azeite de oliva, bem como o uso de pimentas e pimentões, como Afonso Roperto frisou. Além do molho de tomate, uma presença marcante que está associada, segundo sugerem Capatti \& Montanari (1999) ao seu uso entre as camadas populares, pois se tratava de um ingrediente desprezado pelos mais privilegiados, já que era uma planta considerada tóxica até meados do século XVIII.

Segundo os autores, o padrão na cozinha italiana de uso de poucos ingredientes, acessíveis, sem uso de grandes técnicas e que sejam fundamentalmente frescos, permitiu criar adaptações em situações de encontros culturais, multiplicando as opções de uma mesma base, como as massas e as pizzas. Não era a comida que estava dando sofisticação ao restaurante, embora Aurélio Guzzoni tenha afirmado dessa forma, mas a forma como era preparada e para quem. $\mathrm{O}$ padrão da cozinha aparentemente se manteve, mas o que a diferenciou de outros restaurantes foi o fato de ser manipulada por cozinheiros profissionais e servida a membros de camadas favorecidas.

A questão de tentar reproduzir padrões da cozinha localmente, especialmente o uso de ingredientes frescos, esteve presente também na fala de Giovanni Bruno ao relatar seu espanto com relação ao baixo consumo de verduras e legumes, além de técnicas pouco sofisticadas em alguns preparos: "só tinha couve, espinafre e brócolis [...] molho branco era leite com maisena". Ele também descreveu os pratos do dia servidos que disse serem servidos no Gigetto, embora um pouco diferentes daqueles elencados por Ana Paula Lenci.

Ele descreveu o cardápio da seguinte forma:

$2^{\mathrm{a}}$ feira - virado à paulista (costela de porco, ovo, couve, batata frita e arroz branco)

3- feira - rabada

4a feira-dobradinha

5 a feira - nhoque com frango

6⿳亠口了 feira - bacalhau

Sábado - feijoada

Ele disse que domingo era o dia das pastas, sobretudo lasanha, também pediam filé à parmegiana, com muito queijo e molho de tomate, um prato que tinha muita saída quando as famílias iam almoçar nesse dia e podiam dividir as porções, normalmente servidas de modo

164 Ver Alvim (1986). 
farto e abundante. Na verdade, essa fartura estava associada às cantinas e menos encontrada nos restaurantes distintos, onde normalmente a porção era individual e não para ser dividida entre os membros da mesa. Ele também contou que as cantinas ainda eram tímidas nos anos 1950 e 1960, mas entre os anos 1970 e 1980 conheceram sua época de ouro, embora o Brás começasse a decair e o Bixiga começasse a se firmar como um lugar para comer comida italiana.

Observação semelhante foi feita por Antonio Carlos, mas complementou dizendo que não era só o Bixiga, o centro ainda era um lugar que atraía pessoas para comer em restaurantes, pois em suas redondezas estavam ainda o Gato que ri (restaurante antigo no Largo do Arouche), Almanara, Casa Ricardo, Dinho's, Rubayat, Dulca, hotel Vila Rica.

Antonio Carlos, do restaurante Carlino, enumerou os seguintes pratos:

2ª feira - virado à paulista

3ํ feira - mocotó à baiana

$4^{\text {a }}$ feira - feijoada

5ㄴ feira - capeletti

6aㅡ feira - vatapá ou bacalhau

Sábado - feijoada

Domingo - fechado

Dispondo as informações em um quadro para visualizar melhor:

\begin{tabular}{|c|c|c|c|c|}
\hline $\begin{array}{l}\text { Restaurante } \\
\text { Dia da semana }\end{array}$ & Gigetto & $\begin{array}{c}\text { Giovanni } \\
\text { Bruno }\end{array}$ & Ca'D'Oro & Carlino \\
\hline $2^{a}$ feira & $\begin{array}{c}\text { Galeto ou } \\
\text { cotechino com } \\
\text { lentilha } \\
\end{array}$ & Virado à paulista & $\begin{array}{c}\text { Rabada com } \\
\text { polenta }\end{array}$ & Virado à paulista \\
\hline $3^{a}$ feira & Rabada & Rabada & Dobradinha & Mocotó à baiana \\
\hline $4^{a}$ feira & Dobradinha & Dobradinha & $\begin{array}{l}\text { Coelho com } \\
\text { polenta }\end{array}$ & Feijoada \\
\hline $5^{a}$ feira & Ossobuco & $\begin{array}{l}\text { Nhoque com } \\
\text { frango }\end{array}$ & $\begin{array}{c}\text { Risoto à } \\
\text { milanesa com } \\
\text { ossobuco } \\
\end{array}$ & Capeletti \\
\hline $6^{a}$ feira & $\begin{array}{l}\text { Mariscos à } \\
\text { provençal }\end{array}$ & Bacalhau & $\begin{array}{c}\text { Bacalhau com } \\
\text { polenta }\end{array}$ & $\begin{array}{l}\text { Vatapá ou } \\
\text { bacalhau }\end{array}$ \\
\hline Sábado & Feijoada & Feijoada & Feijoada & Feijoada \\
\hline
\end{tabular}


Apesar dos discursos que estabelecem uma diferença entre cozinhas, na realidade o uso de miúdos denota que a princípio a cozinha italiana não oferecia grandes distinções, a não ser talvez no uso da polenta que marcou o Ca'd'Oro. Os miúdos estão presentes em vários dias, o peixe às 6as feiras, indicando uma herança ainda presente de preceitos da religião católica e feijoada aos sábados.

O descompasso entre as narrativas e o que estava transcorrendo na prática ainda pode ser notado no uso intensivo de carnes que hoje são consideradas de menor valor, como foi o caso dos miúdos. Embora nos discursos os grupos estivessem bastante separados pelo tipo de comida, as carnes secundárias estavam à mesa de restaurantes mais simples como os mais sofisticados. No fundo, era uma forma de estabelecer as fronteiras internas de uma comunidade que não se via homogênea, porém agora marcada entre o sul, correspondendo aos italianos mais antigos e seus descendentes e o norte, os italianos mais recentes.

Na verdade, os tempos da cozinha começavam a ser modificados, bem como os personagens envolvidos com o preparo e aqueles que estariam sentados à mesa esperando pelas refeições. As técnicas caseiras, a dedicação e o envolvimento com a comida não teria mais a presença feminina importante nos primeiros tempos para legitimar uma comida entre imigrantes italianos. Os limites da cozinha doméstica e da cozinha de rua começavam a ficar mais claros, bem como de quem estaria encarregado de suas atividades ${ }^{165}$.

No caso das cantinas, a presença das mulheres ainda era sentida e não desapareceu por completo, especialmente representada pelas mammas ou nonnas, mas já não eram figuras fundamentais nos novos restaurantes. A comida dos novos restaurantes, apesar de uma origem modesta, parecia ganhar mais poder civilizador porque provinha de "receitas centenárias, era feita por cozinheiro profissional e servia gente que não eram os italianos de sempre", como disse Aurélio. A comida italiana ganhava um novo espaço na cidade e se tornava também uma referência de distinção. Era legitimada pelo conhecimento tradicional, pelos livros, pelo preparo profissional e se afastava dos pobres imigrantes que vieram no começo do século, evidentemente classificados em uma posição inferior pelos italianos mais recentes.

Em parte, comer fora e saborear novos pratos é decorrente das possibilidades que se apresentavam em um novo cenário urbano. Esse ponto não emerge nas narrativas, mas é clara a separação entre cozinha do norte e sul como espécie de dobradiça que abrirá e fechará os ritmos que marcarão as diferenças entre italianos. A cantina era a reprodução simbólica de valores e trajetórias de italianos com origens humildes, os restaurantes refinados correspondiam aos italianos que vieram após a $2^{\text {a }}$ guerra, mas também dialogava com um cenário urbano totalmente distinto. A cidade crescia e as indústrias bem como o setor de serviços abriam novas oportunidades de ocupações e dinâmicas antes nunca vistas. A comida italiana acompanhou essas transformações e marcou sua presença na cidade.

165 Abordei essa discussão em meu mestrado, Collaço (2003). 
Os restaurantes, na verdade, se tinham na retórica um distanciamento acentuado entre norte e sul, as diferenças se manifestavam em outros pontos. Do lado da cozinha, as diferenças de pratos são claras, mas também quem está encarregado de cozinhar, do lado do salão, afetando o consumo. Nas cantinas era possível encontrar um público boêmio e artistas, mas também algumas famílias de italianos e seus descendentes que começavam a frequentar cantinas para manter proximidade com que remetia à italianidade. A costura é rompida quando os restaurantes refinados introduzem novas relações entre produção e consumo, definindo-se como educadores do gosto.

Nesse caso, é muito interessante perceber essa retórica ao traçar a introdução de pratos feitos a partir da técnica de flambar, ou seja, submeter o alimento à combustão por meio de uma bebida com alto teor alcoólico, processo que era feito à frente do cliente, utilizando um carrinho e um fogareiro. Era o início de um período em que o serviço de salão, o atendimento ao público, será o grande atrativo dos restaurantes refinados em contraponto às cantinas.

Com essa técnica, o tempo de preparo de molhos e carnes é reduzido, assim como é feito essencialmente pelos homens que manipulam o fogo. A relação entre cliente e atendente torna-se central e confere um caráter novo à cozinha italiana, público e masculino. São novas civilidades presentes na comida, uma vez que esse tipo de relação é bem mais formal que aquela encontrada em cantinas.

Na verdade, era um momento de transição entre vários modelos e convívios que demarcavam a existência de novas sociabilidades urbanas. Se o Gigetto lançava mão de um atendimento impecável como descreveu Giovanni Bruno, ainda existia um contato em que predominava o vínculo de amizade, menos evidente no Ca'd'Oro. Ele contou que:

\footnotetext{
Naquela época, o atendimento aos clientes era muito mais trabalhoso: ao servir um frango, levava-se junto uma lavanda quente para lavar as mãos. O café era servido em uma xícara escaldada. Quando alguém ia ao toalete, por exemplo, o garçom ficava esperando à porta com uma toalha, que serviria para o cliente enxugar as mãos. Com o passar do tempo o perfil dos frequentadores dos restaurantes foi mudando e alguns desses requintes foram deixados de lado. Aos poucos, o serviço de garçom foi ficando mais descontraído. (BRUNO, 1994 p.82)
}

Contudo, o Gigetto foi flexibilizando suas regras de atendimento em função da clientela que predominava, o contrário ocorreu no restaurante Ca'd'Oro, onde era necessário fazer reserva, se vestir apropriadamente e seguir os códigos de etiqueta reservados aos restaurantes mais refinados. E, segundo Aurélio, seus pratos não foram de imediato aceitos, especialmente o risoto com açafrão, causando comentários entre os comensais que acabavam sendo disseminados em jornais da época.

Dessa forma, o Gigetto usava pouco o carrinho com fogareiro, segundo lembrou Giovanni Bruno, sendo uma técnica mais específica de restaurantes mais elegantes e que de fato " $f e z$ 
escola em São Paulo", pois durante anos foi um indicador do tipo de serviço e qualidade do restaurante. Além do Ca'd'Oro, o Don Fabrizio também fazia uso dos fogareiros, como já comentado anteriormente, utensílios preciosos para a família Tatini ${ }^{166}$.

Na verdade, a grande introdução de Guzzoni, bem como da família Tatini talvez não tenha sido a cozinha italiana do norte, mas o fato de ter trazido receitas que estavam em livros, preparadas pelos cozinheiros e até então uma raridade no cenário paulistano. Além disso, eram servidas de maneira performática para um publico que estava aprendendo a comer fora de casa e saborear novos pratos.

Nas cantinas as inovações são mais lentas, segundo Afonso Roperto narrou, "Sempre com muito cuidado. Toda a família participa do processo". Para introduzir qualquer novidade no cardápio o processo é lento, como foi o caso dos cogumelos e do tomate seco, sendo as avós e mães as primeiras a serem consultadas. De sua perspectiva, "elas entendem de comida, o cliente vem procurando a perna de cabrito, o fusili, não pode tirar, mas também não pode ficar sem prestar atenção ao que acontece em volta, veja os vinhos". Ele lembrou que nos anos 1950 e 1960 era muito raro alguém pedir um vinho para acompanhar a refeição e hoje não ter esse item no cardápio é simplesmente uma afronta.

Ele lembrou também que sua avó, Teresa, trabalhou na cozinha do restaurante, ajudando sua bisavó Rosa Maria, mas sua mãe já ficou afastada das atividades quando a maioria do trabalho foi passada a funcionários, boa parte deles nordestinos. Mas, Afonso lembrou que o emblemático dessa época era a macarronada com grande apelo e sinônimo de gastar pouco, alastrando seus sabores por outras etnias, "turcos, japoneses todos vem comer comida italiana.", fato também observado por Angelo Luisi, seus clientes eram de todo tipo, desde os paisani com seus filhos e netos, até "desembargadores, artistas, famílias do bairro e também de outros lugares, japoneses, árabes, todos vinham comer em minha cantina". A cozinha italiana conseguia ultrapassar os limites étnicos e começava a consolidar sua imagem de italiana.

As substituições e adaptações foram necessárias na medida em que se tentou, no início, reproduzir pratos que falassem da Itália deixada para trás, assim como de uma nova experiência. Neste período, a situação é totalmente distinta, italianos e seus filhos já incorporados à cidade criavam novos sentidos para a comida, bem como os italianos que vieram após o conflito mundial. Afonso disse que nesse momento,

\footnotetext{
As pessoas ainda se moviam para comer fora uma culinária italiana e o paulistano tomou gosto por comer fora $[\ldots]$ e até bem pouco tempo atrás tínhamos muita influência italiana [...] o emblemático era a macarronada e [...] comer macarrão transpôs os limites da etnia! [...] mas me parece que os italianos aqui são mais rígidos com os costumes para lembrar sua terra, que na origem já mudou há muito tempo! [...] Os velhos são conservadores e os jovens são mais abertos e assim as coisas vão!
}

166 Ver também Beardsworth \& Kiel (1997). 
Nesse sentido, ele percebeu mudanças no gosto ao longo dos anos, mas especificamente chamou a atenção para o fato de que as mammas tinham reconhecimento de sua habilidade na cozinha e disso conseguiram formular um modelo étnico e de comunidade que vai perdendo força em função das condições que se apresentaram no pós-guerra. Não perderam de imediato o seu espaço, mas ficou evidente que seu poder foi sendo limitado à cozinha doméstica que irá tentar manter práticas consideradas importantes na manutenção da italianidade.

É curioso perceber que essa relação não descarta mais um aspecto presente nas narrativas, a ideia de que a imigração foi um diferencial importante para consolidar o caráter cosmopolita da cidade, uma pista sugerida por Pilcher (1998) ao analisar a comida mexicana e a construção de um símbolo nacional. Em seu estudo sobre as diferentes identidades dessa cozinha, o autor notou que o avanço econômico emerge como uma forma distintiva de civilização e a comida se presta para múltiplos discursos nesse sentido ${ }^{167}$.

Tal como o autor sugeriu no México, o papel das mulheres foi central na construção de uma identidade italiana, uma retórica ainda presente nas narrativas, embora nunca associadas à sofisticação, reacendendo a questão do europeu branco como instrumento civilizador que parece estar mais consolidado nos fluxos de italianos que vieram mais tarde. De certa forma, essa ambivalência explora distintas percepções em que se misturam nostalgia, distinção e progresso econômico associado à civilização.

A desigualdade social que, ao menos em origem marcou a diferença entre os grupos de italianos, encontrou no fértil cenário urbano um meio de estabelecer essa distinção, que ainda tentava reforçar o caráter cosmopolita dos novos italianos e seu papel civilizador do gosto, uma vez que muitos provinham de grandes cidades e não do mundo rural. No entanto, a cozinha praticada provinha de mundos semelhantes, embora encontrassem na cidade fôlego suficiente para marcar diferenças, especialmente de classe. A rivalidade culinária nesse período estava nas disputas regionais entre norte e sul como tradutoras de oposições entre rústico e refinado, conhecimento oral e escrito, maior ou menor tempo de imigração, assim como ser italiano descendente ou nascido no País.

Era uma questão de civilizar o apetite e se afastar da fome que estabelecia dois caminhos: um pela gulodice, ou seja, pelas grandes quantidades de comida e que parecia agradar as classes que haviam prosperado, mas de raízes humildes. O outro primava pela qualidade e menos pela quantidade, em especial porque também falava de uma situação mais estável, que não foi o caso de seus antecessores que precisaram lidar com momentos de insegurança ${ }^{168}$. Além disso, frente às dinâmicas urbanas que localmente agiram sobre a cozinha italiana é fato também que a quebra da dependência da transmissão oral dos conhecimentos culinários teve um papel

167 O mesmo olhar parece que foi direcionado ao teatro e a influência italiana na constituição do teatro moderno no Brasil, como discutiu Arruda (2001).

168 Mennell (Op.Cit.). 
importante para legitimar e disseminar um conhecimento que antes estava concentrado em poucas mãos e principalmente, entre mulheres. Se existia um contraste entre italianos, este não necessariamente tinha esse apelo frente à sociedade local que começava a apreciar cozinha italiana.

Mas são nestes efervescentes anos paulistanos que também a Itália se interessa pela comida e são reeditados os antigos livros de cozinha. É também o momento de revitalização de alguns pratos considerados rústicos como a bagna cauda (um molho de azeite de oliva e anchovas), macarrão ao alho e óleo como fontes de inspiração para uma identidade italiana. As regiões têm suas características, mas reunidas fazem da Itália o que é. $\mathrm{Na}$ verdade, prevalece uma ideia do macarrão (espaguete) com molho de tomate como prato nacional, mas as diferenças regionais são festejadas como parte da riqueza cultural italiana e amparadas em um grande conjunto.

É nesse período que uma velha discussão é retomada na Itália e que teve impactos na cozinha, inclusive aquela praticada em São Paulo. Foram dois livros que pregaram caminhos distintos para constituir a identidade nacional italiana e o papel da cozinha escritos por Pellegrino Artusi ${ }^{169}$ e Filippo Marinetti ${ }^{170}$. Os autores com posições opostas compartilhavam ao menos uma preocupação em comum, as futuras gerações. Para Artusi a reunião das distintas cozinhas regionais daria o tom unificador, ao contrário de Marinetti que acreditava que isso era uma decisão política. Mas os limites ficaram claros, não existia uma fórmula capaz de determinar uma ideia nacional de cozinha, mesmo porque isso só foi acontecer muitos anos mais tarde por meio dos livros que circulavam entre membros de classes médias italianas ${ }^{171}$.

Na cidade de São Paulo, coletâneas de livros de receitas não eram usuais nessa época e de fato a cozinha italiana se espalhou mais pela ação das pequenas produções domésticas e mais tarde pelos restaurantes que serviam comensais que saíam para jantar ou almoçar fora de casa como uma atividade de lazer. A cozinha italiana contou também nesse momento com um grande impulso, antes inexistente. Era o início dos programas de televisão e alguns cozinheiros foram chamados para participar, entre eles, Mario Tatini. A autenticidade da cozinha era uma questão interna, aos olhos do público aquela comida simplesmente era uma novidade, como recorda Mario em seu livro.

As classes mais favorecidas se apropriam dessa cozinha e formularam uma noção de igualdade que, na verdade, é apenas aparente. A cozinha italiana resume distintos interesses e incorporar pratos variados provenientes de classes populares não era um objetivo

169 La scienza in cucina e l'arte di mangiare bene (1891).

170 La cucina futurista (1932).

171 Algo semelhante é discutido por Appadurai (1988) na Índia e Pilcher (1998) no México. 
perseguido para consolidar uma noção de comunidade italiana, mas se dava o exercício entre o vulgar e o refinado, embora a olhos locais a diferença estivesse menos na comida e mais no ambiente ${ }^{172}$.

Nesse momento nem se discutia o que era autêntico, mas o que representava uma cozinha distinta, já que ambas não se fecharam ao diálogo local, incorporando e emprestando elementos para constituir uma cozinha italiana aos moldes paulistanos. A comida italiana adquiriu uma faceta civilizadora por meio das comidas sofisticadas e um caráter domesticado pela sua adaptação local. A retórica do progresso é um ponto em comum compartilhado por ambos, mas expressos de maneiras distintas: trabalho é central nas falas dos imigrantes da velha guarda, e o estudo para seus filhos será um diferencial importante para o futuro; o que não representava uma preocupação entre os que haviam chegado recentemente.

Além disso, a comida dos primeiros imigrantes também não condizia mais com as novas condições de trabalho. Como apontou Bourdieu (1979), a seleção de alimentos está intimamente associada ao esquema corporal e aos efeitos dos alimentos no corpo. Comidas pesadas e gordurosas eram menos eficientes entre os novos profissionais que exerciam trabalhos com menor esforço físico, embora os transportassem aos tempos da infância.

Os avanços econômicos da cidade fertilizaram esses encontros em um ambiente especialmente favorável à cultura, à comunicação e aos novos contatos. A cidade buscava firmar sua imagem cosmopolita e necessitava desse convívio plural para fortalecer sua imagem. Como disse Wally, “os filhos vão ter profissões e isso por si só já era uma condição mais próspera para as famílias italianas". Mas, o arejamento proporcionado pelo novo grupo de imigrantes italianos após a $2^{\underline{a}}$ Guerra foi crucial para os desdobramentos desse período e alçar a cozinha italiana ao centro das atenções da cidade.

As disputas entre localismo e cosmopolitismo tentavam elucidar os caminhos da modernidade paulistana e a cozinha italiana representava um sopro de civilização necessário para transformar a cidade em uma metrópole que abandonava suas raízes rurais e cada vez mais se mostrava como o coração industrial do País. O trigo e sua multiplicidade de usos e que, em boa medida, os italianos expandiram na cidade, se traduziu na comida servida em restaurantes nos anos 1950 e 1960, além de novos ingredientes (verduras e legumes) e carnes. Essas lógicas se expressavam de distintas maneiras na cozinha italiana e moldavam novas sociabilidades entre distintos grupos urbanos.

172 Em um depoimento sobre Giovanni Bruno e seu trabalho no Gigetto, Inácio de Loyola Brandão comentou que o restaurante era um mito, mas tinha frequentadores muito variados. À noite eram boêmios, intelectuais, gente das artes que desapareciam aos sábados e domingos, quando a "burguesia" se apossava do espaço, bem como nos horários de almoço só circulavam "engravatados" e comentados em Bruno (1994). O que não deixa de ser interessante, pois se aproxima muito do uso das praças de alimentação de shopping-centers, tema de meu mestrado, Collaço (2003). 
Ser civilizado traduzia então ideal de modernidade que eram absorvidos de formas distintas pelos italianos. Se por um lado seguir receitas tradicionais evocava uma imagem de tradição, reforçava outro aspecto menos evidente, precisava do conhecimento escrito e, portanto, de maior preparo que se dizia mais condizente com a mao de obra profissional, nesse caso cozinheiros homens. O que é curioso é que por muitos anos as técnicas dessa cozinha dita profissional foram repassadas via oral e não por meio de livros ou escolas especializadas, pois a mão de obra que substituiu as mulheres na cozinha foram migrantes humildes que vieram do Nordeste. Evidentemente, não possuíam nenhum tipo de formação apropriada para o setor, assim como tinham dificuldades de compreensão quando a receita era escrita.

Em sua maioria, esses novos funcionários eram também analfabetos e aprendiam as receitas pela observação e repetição, mecanismo similar ao empreendido no ambiente doméstico. Era uma civilização que circulava de maneira desigual, assim como o conhecimento que não necessariamente uma vez adquirido concedia algum tipo de diferenciação ao cozinheiro de origem humilde, pois ele permaneceria sendo um trabalhador braçal.

Contudo, as perspectivas um pouco melhores se apresentavam nos salões, espaço que também começava a se profissionalizar, como lembrou Aurélio e Mario Tatini. Os migrantes nordestinos que não iam para a cozinha, iam atender o público e muitos conseguiram abrir seus próprios restaurantes depois de vários anos de trabalho como empregados. Inicialmente, a maioria dos garçons nessa época era de origem estrangeira, como lembrou Giovanni Bruno, em geral italianos ou espanhóis.

Trabalhar no salão era uma oportunidade inigualável, continuou o mesmo interlocutor, já que ali existia uma perspectiva de se transformar em um empresário como foi seu caso e de muitos de seus discípulos. E não se restringiu aos imigrantes, pois à medida que progrediam e não se interessavam por esse tipo de atividade, também eram substituídos pelos migrantes nordestinos seguindo passos semelhantes, o mais conhecido Francisco Lellis, da Cantina do Lellis que de italiano apenas o fato de ter trabalhado com um, Giovanni Bruno.

O passado imigrante é apenas uma referência positiva quando se prospera e se colocam em confronto membros de distintas correntes, especialmente quando ocupam posições atuais de maior prestígio social, como foi o caso de Fabrizio Fasano ao contar a trajetória de seu avô,

\footnotetext{
Olha, apesar de meu avô ter vindo para cá no fim do século XIX ele já era rico lá na Itália. Ele não veio como esses outros imigrantes. Ele era confeiteiro de profissão, e logo abriu a Brasserie Paulista, em 1902. Não vinha para trabalhar no café, ele já queria abrir seu negócio.
}

Segundo a análise de Goody (1982), até a chegada do novo grupo a hierarquia no interior da comunidade era menos visível, existia, mas demarcava diferenças que tinham como lógicas a origem regional, o tipo de trabalho exercido e a trajetória da família. Com a chegada de novos 
fluxos, essa diferenciação tornou-se mais nítida e marcada pela classe, inclusive nos restaurantes.

A situação não era confusa porque não existiam tantos restaurantes e em parte traduziam o espírito cosmopolita do momento, ajudados ainda pelas novas formas de comunicação, como a televisão. Era na verdade um processo em que as camadas médias adquiriam um conhecimento proporcionado pelos novos sabores e sociabilidades, orientando suas escolhas de uma forma que as preferências denotassem pertencimentos de classe.

É interessante notar, contudo, que os interlocutores se referem de maneira sutil a essa distinção, mas concordam com o fato de que foi essa cozinha italiana a responsável pelo despertar de um interesse local para as refeições fora de casa e permitiu que mais pessoas a consumissem, antes restrita ao universo étnico. Contudo, se havia preocupação em manter um contato estreito com as origens por meio da comida, esta também era uma forma de se aproximar da sociedade local.

Essa oscilação da cozinha italiana é mencionada de modo sutil para demarcar diferenças de origem e formas de conduzir o trabalho, sempre com a intenção de estabelecer uma comparação capaz de delimitar posições. Uma ruptura que se apresenta na ordem da distinção e, mas especificamente na dicotomia entre comida de imigrantes pobres e comida de italianos com posição mais favorecida. Esse ponto ainda deixa claro que novas relações estão sendo constituídas entre o velho e o novo, bem como com o trabalho feminino.

Outro fator interessante é que nesse momento as massas também se tornam mais acessíveis à medida que sua fabricação é mecanizada e distribuída em vários pontos de venda, facilitando seu acesso. De certa forma, as massas ganham popularidade e também adquirem características civilizadas pelo fato de ser um produto industrial, tal como foi o caso das tortillas produzidas em larga escala, fortalecendo um elo entre industrialização e civilização ${ }^{173}$. Mas é também quando se conquista maior acesso a um produto que antes circulava de maneira artesanal e ainda pouco evidente.

É neste momento que surge um leque de cozinhas que poderão ser concebidas como distintas e que evidenciam as diferenças de acesso ${ }^{174}$. Na esteira desse pressuposto certos aspectos são abandonados nesse processo, e em especial o fato de que a cozinha inicialmente exercida ser fundamentalmente de pobres. A cozinha italiana não valorizaria esse aspecto e sim sua força de adaptação ao mesmo tempo em que reconhece suas origens. Vive com um pé no passado e outro no futuro para entender onde se encaixa nesse momento.

As divisões regionais acabaram sendo reduzidas para uma dicotomia entre norte e sul, que em boa medida fala de uma divisão de classes, diluindo a noção de imigrante, reforçando a noção de italiano de diferentes classes derivada das origens italianas. E embora não dito de maneira

173 Pilcher (Op.Cit.) observou algo semelhante no México.

174 Sobre esta questão, consultar também Mennell (Op.Cit). 
direta, surge também uma diferenciação entre italianos de distintas temporalidades, os mais antigos na cidade e os mais recentes, os mais distantes da Itália pátria e os mais próximos.

De origem européia e branca, a cozinha italiana acompanhava o processo de modernização da cidade e este junto na construção de novos hábitos de consumo e lazer. Simbolicamente poderia ser o embate entre o velho, que mais tarde será recoberto de um valor positivo, e o novo. Por um lado, a cozinha italiana dos primeiros imigrantes precisava perder seu estigma, e o conseguiu por meio da incorporação de técnicas da gastronomia francesa. As descontinuidades internas entre italianos permaneceram, mas ante os olhos locais transformou a cozinha italiana em apropriada e será tomada como um importante aspecto na formulação de uma identidade urbana que mais tarde se apoiara nesse ponto para valorizar sua distinção com relação a outras cidades.

Era um momento de negociar a adaptação à sociedade local, se o imigrante se abrasileirava, também contribuía com sua parte italiana para civilizar a cidade, a conveniência de se mostrar mais italiano ou brasileiro tornava a identidade em um material extremamente flexível e a colocou em um terreno movediço.

A resistência dos imigrantes e, em especial os italianos, notou-se na forma como a sua cozinha foi se imiscuindo pela cidade, criando um espaço para a dialética entre italianos e sociedade local, sem ocorrer uma fusão ou homogeneização. O resultado, na verdade foi um balanço em que ingredientes, técnicas e saberes circularam de um lado a outro até alcançar um ponto compartilhado de maneira mais ampla.

Os italianos agora já mais assentados na cidade e desfrutando de uma posição menos desfavorecida terão novos encontros. Se a cidade se transformou em metrópole e para tanto se valeu das múltiplas linguagens que por ali circulavam decorrentes dos vários grupos étnicos que compuseram seu mosaico social e cultural, os anos 1950 também trazem um novo choque e será no interior do grupo que novas linguagens se debaterão.

A cozinha italiana marcou um fosso já existente entre grupos, mas não dirimiu aspectos importantes das italianidades em formação, como o valor à família e a ética do trabalho ${ }^{175}$. Era na verdade uma diluição de velhas lealdades, como as filiações regionais, mas isso não descarta a existência de novas identidades que a comida deixava transparecer. As técnicas e ingredientes utilizados para o preparo dos pratos comuns, como as massas, podiam demarcar pertencimentos, a partir deste momento irão definir o italiano.

$\mathrm{Na}$ verdade, cozinha em um senso prático sempre será regional, uma vez que as fontes dependerão do local em que é exercida, uma cozinha "real" e próxima e, embora cozinha italiana começasse a se fazer visível na cidade de São Paulo, ela terá uma grande distância com a cozinha italiana praticada no país de origem. A questão de ordem é o que se tem acesso e disponível

175 Ver também Colbari (2004). 
para de fato criar uma cozinha que se, nesse caso identifica o italiano, não necessariamente o faz de modo equivalente se comparada entre o que era exercido localmente e o encontrado na Itália $^{176}$.

De qualquer modo, elementos são relembrados, outros são enterrados para constituir um imaginário de cozinha italiana atrelado à imigração italiana. É verdade que nesse período a consciência de sua colaboração na construção da metrópole ainda estava sendo moldada, mas sem dúvida foi inúmeras vezes associada ao progresso e modernidade vividos nesse período.

No fundo, a cozinha desses italianos não era nem mesmo um conjunto definido de pratos, ingredientes e técnicas, pois estava muito mais amparada pela experiência e suas diferenças internas do que em um arcabouço previamente definido. Assim, mesmo que se esteja falando de uma cozinha italiana, nesse momento nada tinha de nacional, ao menos em termos de sua paridade com a Itália.

A cozinha italiana paulistana falava neste período de imigrantes que desejavam abandonar o estigma de desfavorecidos, tentavam valorizar sua imagem de italianos, mas transitavam entre assumir sua italianidade e sua brasilidade, um dilema aberto pelo confronto com os novos italianos que chegavam após a $2^{2}$ Guerra e evidente nas distintas negociações que emergiram na cozinha desse momento.

176 Essa discussão está amplamente abordada por Mintz (1996). 



\section{Capítulo 3: Cozinha italiana na Capital Mundial da Gastronomia: embates entre o tradicional e o moderno}

\section{São Paulo: Capital Mundial da Gastronomia}

Os pujantes anos 1950 e 1960 forneceram os elementos básicos para transformar o hábito de comer fora em uma atividade de lazer da classe média urbana, contribuição que veio somada ao frenético desenvolvimento das artes e cultura na cidade. Articulando italianos, novas sociabilidades, comida, restaurantes a teia que se formou estabelecia também diálogos com o progresso e cosmopolitismo que permeavam a retórica oficial da cidade.

Este aspecto foi uma referência constante nas memórias dos entrevistados, sempre frisando a importância de sua contribuição para a abertura de um campo ainda desconhecido na cidade, colocando-se muitas vezes como pioneiros de um segmento intocado. Naquele momento, nem mesmo existia uma grande variedade de restaurantes, como muitos lembraram, e não hesitaram em se colocar como espécies de desbravadores, um sentimento compartilhado com orgulho, mostrando que seu trabalho de alguma maneira marcou a trajetória da cidade, especialmente ao ver o atual panorama.

Entretanto, é fato que os arranjos sociais também eram moldados sob novos parâmetros. Comer fora não era comum e, portanto, demandava padrões de comportamento que ainda estavam sendo forjados como indicaram as narrativas de Mario Tatitini, Aurélio Guzzoni e Fabrizio Fasano. Estes trouxeram novos sabores, mas também novas formas de circular no espaço dos restaurantes.

Em paralelo, as cantinas abriam seus espaços para novos comensais que circulavam especialmente pelo centro da cidade que foi por muitos anos o coração da vida cultural. Aproveitando-se dos teatros que funcionavam em suas proximidades, as cantinas atendiam espectadores, atores e gente da vida cultural, definindo uma nova realidade em que comer fora passou a ser uma prática menos eventual. Era também a transposição das barreiras étnicas da cozinha italiana que se aventurava por outros espaços da cidade, bem como por outras bocas que não as italianas.

Foram os anos de ouro das cantinas e dos restaurantes, ao menos desde a visão dos interlocutores. Muitos hoje sentem dificuldades em manter seu trabalho, comentaram que os filhos não se interessam pelo negócio da família ou se querem dar continuidade, introduzem muitas mudanças que nem sempre mantêm a fidelidade ao projeto inicial. São as dificuldades que emergem na "Capital Mundial da Gastronomia", ou capital gastronômica, título atribuído à cidade de após uma longa campanha empreendida pelo presidente do Sindicato de Hotéis, Restaurantes, Bares e Similares de São Paulo (SinHoRES), Nelson de Abreu Pinto. Envolvido há muitos anos no setor, ele ainda assume a presidência de outras instituições, entre as quais a 
ABRESI (Associação Brasileira de Gastronomia, Hospedagem e Turismo) que empreendeu uma vasta campanha para a consolidação da imagem "São Paulo, Capital Mundial da Gastronomia”. O seu mais amplo e arrojado projeto e finalmente concedido em 1997 no $10^{\circ}$ CIHAT - Congresso Internacional de Gastronomia, Hospedagem e Turismo, lançado uma década antes no $1^{\circ}$ CIHAT.

Articulando representantes de setores do turismo, restaurantes e meio político para conquistar essa denominação, o projeto desenvolvido pela ABRESI foi uma forma encontrada por Nelson de Abreu Pinto de estimular o turismo da cidade de São Paulo. A instituição iniciou uma campanha em 1988 para conquistar a denominação de Capital Mundial da Gastronomia, título que não é exclusivo, pois a denominação já é atribuída a outras treze (13) cidades $^{177}$.

Passada uma década e consolidando, em 1997, seu título de Capital Mundial da Gastronomia, o jornalista Josimar Melo, conhecido pela sua especialização na área de restaurantes, analisou o cenário local e não via motivos de afirmar que São Paulo era uma capital gastronômica. Veterano na área, ele argumentou que a cidade era ainda um local ainda inexplorado, embora com algumas melhoras nos restaurantes. Para ele, ainda não existia sequer uma tradição gastronômica e nem mesmo guias com poder suficiente para consagrar os chefs de cozinha como acontece na Europa. Nesse caso, cita o guia Michelin, famoso por conceder estrelas aos melhores restaurantes e quando as retira, caso raro, é assunto por anos ${ }^{178}$.

O mesmo jornalista continua em seu artigo que a cidade estava passando por um período de mudanças, havia uma explosão de novos estabelecimentos, alguns desaparecendo logo depois e outros mantendo suas atividades, superando o que ele denominou de modismos. Para outro comentarista, David Zingg ${ }^{179}$, o fato de São Paulo ser uma capital gastronômica outorgada de si para si mesma não lhe daria legitimidade. "A maior parte dos restaurantes e bares chiques desta cidade não duraria uma semana em algum subúrbio de Nova York". Em uma reportagem anterior $^{180}$, emerge uma critica à imposição do impíteto Capital Mundial da Gastronomia, "os vereadores [...] tentam empurrar a cidade para o primeiro mundo com a caneta". Sem eleição, o aval foi dado pela Câmara Municipal, embora com o reconhecimento de consulados de vários países. Para Laurent Saudeau, chef famoso à época, "É uma distorção desleal para iludir o

177 Segundo o relatório preparado para desenvolver um projeto na cidade de Lyon, "Lyon - Capital Mundiale de la Gastronomie?Rapport de Travail Lyon 2020", gentilmente indicado por Julie Csergo, pesquisadora que participou dessa pesquisa e me falou da mesma no 1ํ Colóquio Saberes e Sabores ocorrido na cidade de Curitiba em agosto de 2007, seriam além de Lyon e São Paulo, Paris, Bolonha, Parma, Barcelona, Copenhague, Londres, Dijon, Genève, San Sebastian, Bruxelas, Nova York, Toulouse.

178 Artigo: "Guia consagra "quinteto três estrelas", autor: da Redação, Folha de São Paulo, 05/12/1997. Ver também Mennell (1996) e a história do guia em Masplede (2004).

179 Artigo: "Pacote divide país entre os que 'têm' e os que "não têm”, autor: David Zingg, Folha de São Paulo, 16/11/1997.

180 Artigo: "SP quer virar $1^{\circ}$ por decreto", autores: Rogério Schlegel e Maurício Rudner Huertas, Folha de São Paulo, 21/09/1997. 
consumidor. Depois não somos nós que temos que dizer que somos bons. O negócio é trabalhar e deixar que os outros o digam". Solução simplista que mais tarde terá um impacto profundo no imaginário das pessoas que não só vivem na capital, mas quem a vê de fora.

Josimar Melo, em outro artigo ${ }^{181}$, critica a nomeação pela forma como foi conduzida. Não houve uma enquete ou eleição, e Nelson de Abreu Pinto, presidente de quase todas as instituições ligadas ao turismo em São Paulo, obteve apoio dos vereadores e de alguns consulados para endossar o título. Não que em número de restaurantes de pratos não seja uma metrópole, escreveu o autor, mas não é isso que define ser ou não uma capital da gastronomia. Está em jogo uma cultura gastronômica que, em sua opinião, não existe na cidade. E ainda, dois anos mais tarde, ele continuava a bater na tecla de sempre ${ }^{182}$. Considerava um despropósito o fato de que São Paulo seja uma Capital Mundial da Gastronomia, pois falta um envolvimento sério entre a população local e a comida. Não é a quantidade de restaurantes, mas a devoção dedicada ao bem comer em qualquer que seja o estabelecimento.

Os inventores do titulo de "capital mundial da gastronomia" (na verdade 'autooutorgado' pelo sindicato de restaurantes) deveriam pensar nisso: esconder o sol com a peneira sob um título pomposo não ajuda a fazer da cidade um centro de excelência gastronômica. Ao contrário, estimula o acomodamento.

Alguns anos mais tarde, em uma sala de bate-papo na Internet ${ }^{183}$, o mesmo Josimar Melo continuou a criticar a ideia de Capital Mundial da Gastronomia. Quando perguntado se São Paulo é mesmo a melhor em gastronomia, ele responde que sim, ao menos no Brasil. "Tem comida para todos os gostos e bolsos", e diz que infelizmente o típico na cidade não é a valorização de suas raízes, mas o fato de ser uma grande mistura que a caracteriza como cosmopolita que se oferece nos restaurantes. E na verdade, essa vocação teria como finalidade atender à ausência de outras formas de lazer em uma cidade carente de belezas naturais e com uma crescente classe média com algum dinheiro disponível.

E se hoje São Paulo conquistou certa segurança quanto à gastronomia que oferece, as memórias desse período também são turbulentas entre os interlocutores que, em boa medida, compartilham as mesmas opiniões em torno da denominação. Contudo, São Paulo não está só no universo das Capitais Mundiais da Gastronomia e é interessante tomar a trajetória de sua coirmã mais famosa, Lyon, para discutir alguns aspectos que permitem entrever como diferentes repertórios culturais marcam os sentidos de uma mesma denominação.

Ser uma Capital Mundial da Gastronomia tem para Lyon um grande valor estratégico apoiado em três pilares: comensalidade, ideia de terroir (localidade) e saúde. Os cozinheiros

181 Artigo: “SP, capital mundial da gastronomia?”, autor: Josimar Melo, Folha de São Paulo, 05/09/1997.

182 Artigo: “Capital mundial da gastronomia?”, autor: Josimar Melo, Folha de São Paulo, 24/01/1999.

183 UOL, 25/01/2002, às 18h. Participaram 93 pessoas. 
profissionais seriam os personagens chave, responsáveis pela transmissão do conhecimento do saber gastronômico de Lyon e promotores dessa imagem.

$\mathrm{Na}$ verdade, nem sempre foi assim, uma vez que a cozinha de Lyon não era nem mesmo reconhecida dessa forma nas primeiras décadas do século XX. A consolidação de uma noção mais refinada da gastronomia estava em gestação na França, mas ainda não tinha sido disseminada muito além de Paris. A força desse imaginário reside até hoje em uma cozinha dita burguesa e que teve como pioneiras a mão de obra feminina, as mères (mães) que, em um processo similar ao observado na cidade de São Paulo, abriram suas residências para servir a "autêntica comida local" 184 .

Em parte, esse processo deve muito ao turismo, uma vez que foram classes sociais privilegiadas que começaram a circular pelas estradas para ocupar seu tempo livre do trabalho, as férias. Como muitos se lançavam em seus automóveis precisavam de informações a respeito de onde parar, dormir, comer ou mesmo consertar algum avario. Surge então um guia patrocinado por um famoso fabricante de pneus, Michelin, que abrirá todo um caminho até então inexplorado em torno de guias e roteiros ${ }^{185}$.

As mères ficaram famosas, talvez porque servissem camadas privilegiadas, ao contrário das mammas locais, inclusive foram consagradas em 1933 quando uma delas ganhou as três estrelas do Guia Michelin, prêmio cobiçado pelos chefs de cozinha e concedido ao restaurante da Senhora Brazier, primeira mulher a obter esse reconhecimento. Pioneiras na construção do bom gosto em torno do comer, sua reputação foi sendo diluída à medida que chefs de cozinha se consolidavam no universo dos restaurantes, embora seus vestígios ainda façam parte das reminiscências de Lyon.

Em São Paulo, e no Brasil de modo geral, guias de restaurantes com esse prestígio ainda não estão disponíveis ${ }^{186}$, e as cantinas apesar de reconhecidas em alguns roteiros, em geral são condenadas pela herança das mammas, principalmente ao associar comida de baixa qualidade ao universo doméstico. Nada mencionam a respeito da influência desses restaurantes, uma vez que na cidade de São Paulo quase não existiam opções para comer fora de casa e o trabalho promovido por essa força feminina propiciou um ambiente favorável ao comer fora que, anos mais tarde, consolidaria a imagem de capital gastronômica.

As mères de Lyon tiveram outra sorte. Em 1934, Curnonsky, famoso crítico gastronômico do momento na França, já falava de Lyon como Capital Mundial da Gastronomia, sobretudo pela dita arte de viver e a qualidade dos produtos que oferecia, e em especial a possibilidade de

\footnotetext{
184 O mesmo ocorreu na região da Bourgogne, como mostrou Laferté (2002).

185 Masplède (Op.Cit.).

186 Pelos comentários dos interlocutores, os mais destacados são o guia do suplemento da Revista Veja, a Vejinha e o Guia 4 Rodas, sendo que este perdeu muito de sua importância nos últimos anos, embora ainda seja uma referência importante para o turismo nacional, feito à imagem do Guia Michelin.
} 
saborear bons pratos locais preparados pelas pessoas que mais entendiam do assunto, as méres. As ideias de uma comida caseira, honesta, bem feita, serão os enunciados que repetidamente irão associar-se à ideia da gastronomia de Lyon e que valorizaria a simplicidade, a autenticidade, o gosto da comida, saudável, prazerosa, social.

É neste ponto que se repara uma diferença entre as duas capitais mundiais da gastronomia, Lyon se vale dos produtos locais para estabelecer sua primazia sobre outras cidades, habilmente combinados e executados por cozinheiros locais, cujas raízes estão concentradas nas mères. Essa herança gastronômica justificaria anos mais tarde os motivos pelos quais se desenvolveu um movimento de grande influência conhecido por nouvelle cuisine (nova cozinha), nascido nessa cidade e ganhando o mundo quando seu famoso difusor, Paul Bocuse, conquistou três estrelas do guia Michelin.

Essa elitização da cozinha não deixou, contudo, que seu lado popular desaparecesse, já que no plano simbólico a cozinha local estava ainda muito ligada à obtenção do prazer e, assim, encontrou ressonância entre as camadas burguesas que continuaram apreciando a dita "cozinha local autêntica". Nesse sentido, a diferenciação da cozinha em Lyon é evidente, mas se trata de um processo que correu em paralelo à cozinha de "coração", isto é, feita com ingredientes tidos como menos nobres, mas de grande expressão com relação ao terroir (território, terra).

Por outro lado, no plano social a mesa é um momento onde se reforçam ou desfazem laços sociais e, portanto, reforçam o convívio social que nem sempre procura pratos excessivamente leves e saudáveis. Nesse quadro, é interessante notar o trânsito quase oposto entre as receitas populares servidas pelas mères e dos chefs com suas novas propostas, sobretudo marcadas pela leveza de preparos. A gastronomia local que se reveza entre tradição familiar e cozinha sofisticada corre o imaginário local, mas também mundial e tenta consolidar Lyon como uma "Capital Mundial da Gastronomia". Evidentemente que essa relação não se esgota nessa oposição, desdobrada hoje em uma ampla diversidade de alternativas que se oferecem em restaurantes conceituais, de cozinha orgânica, étnica, vegetariana entre outras.

Na cidade de São Paulo, essa oscilação entre cozinha saudável e cozinha de "coração" não se deu, mesmo porque a cozinha local não adquiriu a mesma proeminência que a de Lyon. Na realidade, São Paulo amparou seu processo todo em função da quantidade e variedade de restaurantes disponíveis que começou a se fazer notar a partir do fim dos anos 1980. Até então, como se viu anteriormente, a principal participação era de alguns restaurantes de comida italiana e que tiveram o mérito de incentivar o hábito de comer fora de casa.

Na realidade, a capital paulista não possui uma cozinha local para chamar de sua, a não ser a cozinha italiana que criou uma trajetória própria e hoje é praticamente o que identifica a cidade ao lado da ideia de capital gastronômica. A gastronomia como uma identidade da cidade não valorizou elementos de uma cozinha local, ela contemplou a possibilidade de degustar várias 
cozinhas, tomadas como representantes culturais de vários países. E esses sabores poderão ser degustados na vasta quantidade de restaurantes da cidade, de maneira que não se trata de uma excelência local como em Lyon, mas de uma amplitude de sabores e, de certa maneira de culturas, que sustentariam o caráter cosmopolita da cidade.

De fato, não há uma cozinha brasileira reconhecida nem dentro e nem fora do País, salvo alguns pratos regionais que acabam sendo estereótipos esmaecidos da riqueza culinária, além dos produtos exóticos, especialmente da região amazônica que foram incorporados aos cardápios de restaurantes de "cozinha contemporânea". A Capital Mundial da Gastronomia, ao menos pensada em termos de uso de produtos regionais e técnicas utilizadas em determinada localidade, a exemplo do que ocorre na maioria dos países europeus, não condiz com essa noção de cozinha regional. Por outro lado, criou uma interpretação local de uma cozinha vinda pelas mãos de imigrantes que a identifica, apesar de se pensar plural pelas várias influências recebidas.

Assim, o papel da cozinha italiana nesse universo ficou interessante. O que parece existir é uma gastronomia imaginada e outra real, ou pelo menos, uma de caráter normativo, isto é, uma cozinha variada encontrada em restaurantes e assim reconhecida oficialmente pelos meios políticos e pela mídia, mas distinta da gastronomia que normalmente é praticada no cotidiano e mesmo quando se come fora. Nesse sentido, praticamente $70 \%$ dos estabelecimentos listados em guias e roteiros apontam para a comida vinda da Itália, um aspecto inclusive mencionado por interlocutores, como Aurélio Guzzoni que falou:

A culinária italiana é a mais aceita, de cada 100 restaurantes, 64 são italianos e isso desde 1997!!! [...] Na Holanda, por exemplo, você vê um restaurante italiano e você se sente seguro. São 6 milhões de descendentes [...] mas tem muito dono de restaurante de cozinha italiana que não é italiano, mas já foi incorporada.

A popularidade da cozinha italiana, inclusive das pizzas, é tão notória que um rápido olhar em guias e roteiros de restaurantes é possível perceber a supremacia do gosto pela culinária italiana ${ }^{187}$. Essa constatação é semelhante ao que Adolfo Scardavelli falou sobre a culinária italiana em São Paulo, embora "você tenha comida do mundo inteiro das melhores qualidades [...] você encontra de tudo. Em matéria de gastronomia é muito bom [...] eu acho que se deve à imigração". No entender de Adolfo, a cozinha italiana predomina, mas foi graças a ela que se pôde ter uma abertura na gastronomia local, embora nem todos os grupos tenham enveredado pela mesma trajetória.

187 Foram utilizados o Guia Josimar Melo, Roteiros de restaurantes do Jornal Folha de São Paulo e o sítio da Internet da Revista Veja-São Paulo. Esse recurso foi uma estratégia metodológica no sentido de reduzir o universo de análise já que os números, embora bastante imprecisos, afirmam que são 12.500 restaurantes e 5.000 pizzarias, segundo dados da Folha On-line/450 anos. 
Ao considerar outros grupos expressivos, como os portugueses, e mesmo os espanhóis, a exposição de suas cozinhas foi bem mais modesta que os italianos. O fato de a cozinha italiana ter avançado os limites domésticos e étnicos foi um diferencial considerável para sua exposição pública e construir pontos de proximidade com a sociedade local. Além disso, embora os interlocutores não comentem com clareza acerca desse respeito, o abastecimento de produtos ditos italianos ampliou-se, facilitando o acesso e o uso de produtos, especialmente as massas.

Mas é fato que se há "6 milhões de descendentes", não há uma correspondência direta entre gosto e consumo de comida italiana, mesmo porque os próprios descendentes apresentaram em vários momentos posições ambivalentes com relação ao consumo de comida italiana, especialmente quando associada a valores e costumes que não desejavam incorporar. Em alguma medida os descendentes desses primeiros imigrantes transitavam entre o italiano e o brasileiro, o que por si já afetaria as percepções em torno dessa cozinha.

As famílias de descendentes ora assumem uma postura italiana, ora brasileira, o que faz parte de suas negociações identitárias em um contexto em que precisam demarcar uma posição ${ }^{188}$. A cozinha italiana que emergiu em restaurantes nos anos 1950 e 1960 denotou essa ambivalência que será submetida a novas interpretações ante o processo de globalização da cozinha italiana, iniciado no fim dos anos $1980^{189}$. Se assim fosse, as cantinas continuariam servindo os paisani e os seus filhos, o que já havia sido superado no período anterior. A cidade impõe novas dinâmicas que expandirão as fronteiras do paladar, embora sem ignorar o material já existente.

Hoje as antigas cantinas que conseguiram sobreviver convivem com um punhado de clientes e se desejam faturar um pouco mais precisam apelar para outros atrativos, como o turismo. $\mathrm{Na}$ verdade, os novos espaços da família foram transferidos para as pizzarias, espaços de uma nova cena de lazer. A cozinha italiana restrita às cantinas e alguns restaurantes mais refinados se viu diante de uma diversificação de sabores e conceitos de cozinha proporcionados pela Capital Mundial da Gastronomia, abrindo possibilidades de experimentação que deixará ao comensal, a dúvida do que irá comer hoje.

Os valores da cozinha paulistana revelam, assim, outras associações calcadas, sobretudo, na adaptação, diversidade, trabalho e progresso que articulados oferecem um universo cosmopolita de sabores. Imigrantes, especialmente europeus e brancos, possibilitaram o desenvolvimento da cidade e alcançar o status de metrópole. A comida italiana hoje resume essa nova fase porque também é uma cozinha global e que se encontrou como uma cozinha italiana local moldada sob um tempo distinto.

Essa profusão de opções é para muitos entrevistados o resultado de uma campanha que gerou confusão e desconforto. João Donato não encontrou vantagens para seu estabelecimento $188 \quad$ Lesser $(O p . C i t)$.

189 Para esta discussão, consultar Gabaccia (Op. Cit.), LaCecla (Op. Cit.), Goody (Op. Cit), Cappatti \& Montanari (Op. Cit), Serventi \& Sabban (Op. Cit). 
pelo fato de a cidade ser uma capital gastronômica, ao contrário, de sua perspectiva isso apenas criou uma ilusão em torno da qualidade do que é servido, abrindo um leque de opções nem sempre satisfatórias para os comensais. João comentou que:

\begin{abstract}
A comida de São Paulo está muito sofisticada, afinal você está em uma capital gastronômica e você tendo [fez gesto friccionando o polegar no indicador significando dinheiro] você come o que quiser. Não tem época, é tua carteira cheia que vai mandar [...]. Quando comecei a trabalhar existia pouco restaurante, limitados a uns poucos pratos. Hoje existe muita perfumaria, você põe na boca, você sente o tempero, não o principal. Muito condimento, muita coisa nossa! E põe mostarda, essas porcarias hidrogenadas. O ruim mudou para pior, não é que melhorou, antigamente eu comia um bife, hoje não.
\end{abstract}

Para ele, esse fenômeno trouxe desvantagens, pelo menos para a condução de seu estabelecimento, uma vez que para ele e seu herdeiro, Fábio, a manutenção do restaurante como está é fundamental. Eles cogitaram a possibilidade de abrir uma filial em um bairro de maior movimento, porém "mantendo as características da original", pois para eles servir o mesmo prato há 85 anos é uma questão central.

Outras pizzarias com vários anos de existência também enfrentaram o dilema de abrir uma filial sem perder suas estimadas características. A Speranza que está no Bixiga e a Monte Verde no bairro do Bom Retiro decidiram expandir e se instalaram em bairros de maior crescimento de camadas médias, principalmente na zona sul da cidade, como Itaim e Vila Olímpia ${ }^{190}$.

Outros sentiram que apesar de sua tradição foram preteridos pela capital gastronômica e em seu lugar novos estabelecimentos vieram para servir aos comensais ávidos por experiências do comer que nem sempre são de boa qualidade. Muitas das novidades seriam apenas espumas, já que não se sustentam por muito tempo, segundo comento Aurélio, pouco benevolente com a questão da capital gastronômica. Ele disse que:

\footnotetext{
Essa coisa de capital gastronômica foi uma jogada eleitoreira de Nelson Abreu Pinto, do sindicato. Ele criou esse movimento e depois foi um marketing para São Paulo, sobretudo nos anos de 1999 a 2004. São Paulo estaria entre as maiores cidades, mas não tinha sentido fazer isso, foi mais para estimular o turismo de negócios e o restaurante dele que andava mais ou menos, lá no Bixiga.
}

Segundo Aurélio, corroborado por Afonso Roperto, Nelson de Abreu Pinto tinha uma cantina na Rua 13 de maio que não andava muito bem, assim como tantas outras. Interessado em se lançar como um líder do setor, e melhorar o faturamento de seu restaurante, encontrou uma saída para transformar São Paulo em um atrativo turístico, sobretudo para aqueles que a visitam a negócios. No entanto, para Afonso Roperto, na época em que se instituiu a denominação houve

190 Ver mapa de São Paulo, Apêndice 3. 
muito mais alarde que ficou perdido no tempo. Se a quantidade e variedade de restaurantes e pratos é uma condição para ser capital gastronômica, São Paulo de fato mereceu o título, mas ainda gera dúvidas.

Esse cenário é descrito por Giovanni Bruno de maneira superlativa:

É uma grande metrópole gastronômica (São Paulo), esse prêmio é justo e as pessoas vêm para São Paulo pela abundância, pela nossa quantidade de opções. [...] Hoje as cantinas, como o Capuano, mantém a tradição com 2 ou 3 pratos, os outros se dizem cantinas, mas perderam sua tradição. [...] Infelizmente, dentre alguns anos, a tradição e o artesanal vão acabar. [...] A rapidez está acabando com os pratos "tradicionais" [...], as raízes foram os chiques, e agora cresceu, veio restaurantes, de um Carlino, de um Gigetto temos um gosto aperfeiçoado. Das pizzarias temos 300.000, de um Gigetto saíram 7.000 restaurantes, do Casserole saíram centenas de cópias. Toda a culinária italiana hoje se aclimatou e viveu as influências do local, os pais e os filhos espalharam o novo gosto pela cidade.

Giovanni Bruno foi um personagem que viveu esses distintos tempos da cozinha italiana e a denominação da cidade como Capital Mundial da Gastronomia, reforçando a importância que a comida teve na formulação de uma imagem cosmopolita. Curiosamente, uma rápida olhada em jornais da década de 1980 dá indícios de que a cidade não tinha vocação gastronômica definida como assinalaram os vários entrevistados e as próprias críticas encontradas em jornais. Inaugurando uma área ainda pouco contemplada, gastronomia, o jornal Folha de São Paulo abriu espaço para uma coluna semanal para abordar o assunto pelas mãos de Silvio Lancelotti. Anteriormente o assunto era tratado por Paulo Cotrim e Saul Galvão, personagens que ficaram conhecidos como críticos e causavam o "terror dos restaurantes", segundo Aurélio, pois uma nota negativa poderia acabar com a fama do lugar. "É o que acontece hoje com a Vejinha, em outra época foi o Guia 4 Rodas, hoje é a Vejinha”.

Mas os críticos não aterrorizavam somente os restaurantes ditos mais refinados, deixaram as cantinas em uma situação desconfortável, uma vez que sua cozinha não adquiria reconhecimento e estas por sua vez não queriam perder os laços com suas origens, mesmo que para isso tivessem que recorrer a novos comensais, muitos de fora da cidade e do estado. Afonso diz que seu restaurante proporciona uma "experiência cultural", ressaltando uma estratégia de valorizar seu passado ao se associar à história de São Paulo. Não é uma comida envelhecida, como muitos jornais e revistas definem a comida de cantina atual, mas uma comida com raízes. Os críticos muitas vezes não julgam esse aspecto, considerado central pelo interlocutor.

Essa relação, inclusive, é marcada por posições que oscilam entre reconhecimento e distância. Os críticos e jornalistas do assunto, gastronomia, são normalmente vistos com certa desconfiança, mas os entrevistados sabem que uma nota favorável poderá contribuir, e muito, para o movimento da casa. Mas nem todos os guias são vistos de modo positivo, Afonso disse: 
O guia 4 Rodas era legal, agora mudou. O da Veja, muita gente acha que tem manipulação, porque quem não é indicado acha que foi 'esquecido'. No caso da Veja, ele pega realmente casas de expressão comercial, acho que é bem feitinho, isso traz influência. [...] Nestes últimos anos tentamos estar sempre presentes, fomos $2^{\circ}$ lugar na lasanha e no dia, vendemos tudo e se tivéssemos mais, vendíamos mais. [...] Na minha mesa sempre tem algo sobre restaurantes, eu to antenado em tudo. Tenho receio que saia algo ruim do restaurante e nos dá um baque.

Desse último ponto, citou o caso do restaurante Boi na Brasa e disse que nem tradição nem nada conseguem apaziguar uma nota negativa de uma revista ou jornal influente. Essa é uma questão espinhosa para muitos interlocutores que nem sempre conseguem uma nota favorável e se indispõe com os meios de comunicação, criando um clima mais pesado para o estabelecimento. Segundo Aurélio, "o restaurante tem que fazer oba, oba", mas é fato que a Veja, continuou ele, tem uma influência forte.

O uso dos meios de comunicação reflete um interesse prático que não descarta a reafirmação de identidades. Para os restaurantes da velha guarda se trata de não esquecer sua contribuição e sua trajetória de imigrante italiano na cidade, realçando aquilo que se considera importante, além de resgatar comensais para seus estabelecimentos. Para os novos restaurantes é ressaltar seu diálogo com a Itália contemporânea e com uma cozinha de assinatura, de chef.

Esse ponto levantou outra questão, pois se até então os restaurantes e suas cozinhas não tinham uma visibilidade importante, a movimentação em torno desse diferencial foi acionado por alguma engrenagem não mencionada claramente. A mídia pode ter tido uma influência importante, como alguns apontaram, mas também o fato de que houve um aumento acentuado no intercâmbio de informações e pessoas pelo mundo, deslocando cozinhas com maior facilidade de um lado a outro, além do aumento de refeições fora do lar.

Em termos locais, é fato que a mídia teve um papel nessa construção. Entretanto, se possui o papel de informar e discutir, de alguma maneira também impõe temor, pois muitos restaurantes ficaram apreensivos em receber alguma menção pouco apropriada, nem sempre considerada "justa", fato que levou a muitos entrevistados mostrarem, inclusive, desconfiança com os jornalistas. Alguns são extremamente mal vistos, embora "engolidos" pela posição que ocupam.

$\mathrm{E}$, apesar de que os interlocutores possuem uma percepção de que a mídia teve especial participação na difusão da Capital Mundial da Gastronomia, não parece ter sido esse o desfecho. A menção a essa característica só começou bem depois da nomeação oficial em 1997. As poucas reportagens encontradas não falam desse título, embora mencionem com frequência a ideia de variedade gastronômica. Em uma reportagem de $1987^{191}$, o autor apontava uma curiosidade, "Em São Paulo é grande a variedade de restaurantes de cozinha exótica, como a escandinava,

191 "Para Variar seu menu de cada dia", Folha de São Paulo, 03/02/1987, de autoria de Heinar Maracy. 
húngara e indiana; há alternativas de pratos típicos que podem quebrar a rotina gastronômica". Comenta sobre os restaurantes em que se é possível consumir essas comidas, mas não faz menção sobre a ideia de capital gastronômica e nem mesmo à comida italiana, sugerindo que talvez já fosse algo já incorporado ao universo local.

No mesmo jornal, no mesmo ano ${ }^{192}$, surge uma reportagem explicativa do que é sashimi, "Trata-se do peixe cru que os japoneses preparam com muito amor. Um prato que além de gostoso é uma obra de arte. Em São Paulo, essa comida é cada vez mais consumida por ocidentais. Confira". Pelo teor dos comentários, a comida japonesa ainda era algo exótica e não totalmente disseminada pela cidade. A grande novidade apontada na matéria era o fato de que a colônia japonesa não era mais a única consumidora de comida japonesa. Alguns donos e trabalhadores de restaurantes japoneses comentavam sobre a mudança de comensais, cada vez mais composto por gaijins (não japoneses) que apareciam em seus restaurantes para provar iguarias da culinária japonesa, ainda bastante restrita ao bairro da Liberdade e um punhado de restaurantes em outros bairros, principalmente próximos à Avenida Paulista.

Outras reportagens assumiram o mesmo ar curioso com relação à cozinha nipônica ${ }^{193}$. Josimar Melo afirmou que "Paulistanos podem provar delícias da culinária nipônica"194, título de sua matéria, ressaltando que "Já se foi o tempo em que ir a restaurantes em São Paulo era sinônimo de comer em pizzarias e cantinas", sugerindo que até não muito tempo as opções para tomar uma refeição fora de casa não eram muitas, como os próprios interlocutores mencionaram diversas vezes.

No mesmo artigo, Josimar Melo ainda afirmou que "Hoje a diversidade é a tônica nos roteiros gastronômicos da cidade. E felizmente há, nesta Babel de sabores, a boa cozinha japonesa", embora segundo observou, a maioria dos restaurantes japoneses tivesse "um ambiente geralmente simples e acolhedor", ainda muitos de caráter familiar e étnico.

Embora faça uma alusão à Babel de sabores, pelo tom das reportagens é fato que ainda não existiam paladares tão abertos ao exótico e comer pratos muito diferentes dos padrões locais não era uma atividade propriamente comum e plenamente integrada à cidade, salvo a conhecida cozinha italiana. Em outro artigo ${ }^{195}$, surge um elenco de restaurantes típicos da cidade que "resgatam a cultura de seus países". Nesse texto, a tônica não é dada ao exotismo, mas à possibilidade de poder realizar "uma viagem pela Grécia, Itália, URSS, Hungria e Portugal”, pois esses países estão representados na cidade ${ }^{196}$. Não há um conceito de cozinha local, mas de

192 “O sashimi ganha cada vez mais admiradores”, Folha de São Paulo, 19/01/1987, de autoria de Mario Viana.

193 Para um apanhado geral da trajetória da cozinha japonesa na cidade de São Paulo, consultar o prefácio escrito por Arnaldo Lorençato no recente livro de Cwiertka (2008) a respeito da cozinha japonesa.

194 Folha de São Paulo, 21/05/1987.

195 "Volta ao mundo em cinco pratos", Folha de São Paulo, 11/10/1989 de autoria de Lydia Mendes.

196 Os restaurantes que a autora enumera são: Samovar (Rússia), Hungaria (Hungria), Abril em Portugal, Zorba o Grego e Capuano. 
restaurantes que concentram uma grande variedade de sabores que podem ser degustados em uma prática que vai sendo consolidada na metrópole.

Coincide essa explosão de sabores com o desenvolvimento de novas regiões que passaram abrigar restaurantes. Além das proximidades da Avenida Paulista, o grande pólo de restaurantes nas décadas seguintes foram os Jardins, especialmente no pedaço entre Avenida Augusta, Alameda Lorena e Rua Bela Cintra ${ }^{197}$. Nos anos 2000 seriam os bairros do Itaim, Vila Olímpia e adjacências.

Piero Grandi abriu sua cantina nos Jardins nos anos 1980. Ex-garçom do Gigetto fez fama pela enorme salada servida com torradas de alho, os pratos fartos, como o fetuccine tricolori com paillard (macarrão colorido com bife na chapa), servindo bem duas pessoas "com muita fome", segundo disse em seu depoimento. A comida não oferecia grandes diferenças com relação às cantinas tradicionais, fenômeno que só foi acontecer nos anos 1990. O que o diferenciava era o fato de ter saído dos bairros tradicionalmente associados às cantinas para aqueles que se mostravam os novos centros de diversão. Ele foi seguido por algumas outras cantinas, como a do Lellis, mas é fato que os sabores começavam a se disseminar fora das antigas fronteiras étnicas e do centro.

Foi o inicio de várias dificuldades entre os interlocutores. Antonio Carlos Marino contou que:

\begin{abstract}
Ninguém falava de capital gastronômica, não como capital, mas era um lugar privilegiado por restaurantes com mais de 50 anos [...]. Ele gastou mais de um milhão de dólares nessa campanha 15 anos atrás (Nelson de Abreu Pinto para nomear a cidade Capital Mundial da Gastronomia, no fim dos anos 1980) e com isso conseguiu aumentar o número de filiados do sindicato e aumentou sua receita [...]. Os italianos foram fundamentais para a construção da capital gastronômica e um pouco dos espanhóis. Os italianos trouxeram a pizza, a 'porpetta' [...] A capital gastronômica paulistana foi instituída simbolicamente [...] um golpe de marketing do presidente do sindicato. Nosso passeio é a comida, nossa praia é a comida, inventar uma data e comemorar é coisa desses vereadores $[\ldots]$
\end{abstract}

A fala de Antonio Carlos resume os sentimentos dos entrevistados com relação à capital gastronômica, nem sempre um ganho para a cidade, para os consumidores, os restaurantes. Foi apenas um instrumento de promoção de um personagem pontual que, no entanto, teve distintos desdobramentos. A principal queixa, por assim dizer, com relação à denominação é que não valorizou o trabalho de restaurantes pioneiros, bem como não falou de suas famílias e sua trajetória como empreendedoras. O golpe de marketing como muitos se referem à concessão do

197 Inclusive outro tema bastante presente nas reportagens era a "Guerra das Churrascarias" abertas a poucos metros de distância na Rua Haddock Lobo, e concentrando tal massa de pessoas que os vizinhos reclamavam que não podiam sair da garagem de seus prédios. 
título beneficiou principalmente o sindicato, embora com o correr dos anos essa ideia tomasse corpo, sobretudo entre comensais ${ }^{198}$.

Sem esgotar as distintas percepções a respeito da capital gastronômica, o que é preciso reter entre os interlocutores é que a cidade não era uma cidade com boa gastronomia, pelo menos do ponto de vista exposto. Essa consciência também é refletida nos artigos de jornal analisados que argumentam sobre a fraca qualidade dos restaurantes da cidade e até mesmo pelo papel que muitos disseram ter como fundadores do bom gosto. João Donato resumiu bem a questão dizendo que para ele essa história não passa de "perfumaria".

Ângelo Luisi concordou com essa idéia, "Se as pessoas soubessem comer, isto aqui estava cheio todo dia", referindo-se à capital gastronômica como um engodo que tentaria vender aos comensais algo que não consegue entregar, mas conquista adeptos pela falta de conhecimento que os frequentadores de restaurantes têm com relação à comida. De certa forma, reitera o caráter civilizador de sua cozinha e das demais cantinas, um aspecto já discutido em outro momento.

A falta quase crônica de clientes o levou a um estado quase letárgico com relação ao seu cotidiano. Sua filha e seu genro o ajudam neste momento, mas manter a tradição do estabelecimento frente às novas linguagens urbanas é extremamente complicado. Ele hoje se sente excluído do mercado, na verdade porque oferece comida (e valores) que estão em desuso.

O tempo dessa cozinha parece que passou, mas não deixa de ser visto com nostalgia e uma ponta de mágoa ante os novos arranjos da capital gastronômica. Esse sentimento também foi notado entre outros entrevistados que não economizavam palavras para ressaltar a tradição de sua cozinha, o afeto depositado no preparo e na recepção dos comensais com a intenção de fazer sentir em casa.

Na realidade, fortalecem elementos que dizem respeito a uma cozinha que lida com vínculos estreitos, comida simples, mas bem feita em uma espécie de reprodução de elementos caseiros que, infelizmente, não são incorporados pelos novos comensais. Em parte, porque muitos acreditam, segundo os entrevistados, que essa comida de cantina é antiquada e "de carregação", perdeu seu sentido frente às novas opções da capital gastronômica. Se para os entrevistados há preocupação com a qualidade e com a tradição, não é essa a percepção que circula entre os comensais, muitas vezes interessados na rapidez, no ambiente e em comidas saudáveis, pois uma das razões apontadas pelos interlocutores para justificar a falta de clientes foi também que sua comida não poderia ser exatamente definida como saudável.

198 Essa constatação foi empiricamente observada ao longo do trabalho de campo anterior, Collaço (2003) e nas rápidas conversas com clientes dos estabelecimentos visitados, embora não houvesse intenção de explorar esse tema sob essa perspectiva, a questão da variedade de restaurantes e cozinhas soava como uma espécie de ganho simbólico em função dos escassos programas de lazer disponíveis na cidade. Comer em restaurante e passear em shopping eram as formas de lazer mais comuns, ao lado de ficar em casa assistindo TV ou filme. Valeria aprofundar essa questão em outro momento. 
As cantinas nasceram e prosperaram sob os auspícios de dinâmicas urbanas muito distintas e não acompanharam o ritmo da metrópole cosmopolita. $\mathrm{O}$ mesmo pode ser estendido aos restaurantes que surgiram nos anos 1950 e 1960 ditos de cozinha italiana refinada que tiveram um lugar particular na formulação de novas sensibilidades gastronômicas. No entanto, existia um vínculo ainda forte em torno do reconhecimento entre grupos, mesmo que difusos e que de alguma forma orientavam escolhas ${ }^{199}$, quer fossem amparadas em reconhecimento étnico, de classe ou origem.

Por outro lado, jantar fora é um programa de lazer com distintas motivações que muitas vezes não cabe no espaço das cantinas ${ }^{200}$, mais associadas ao horário de almoço, especialmente domingos. Nesse sentido, as pizzarias que também seguiram a cartilha do familiar e do convívio sobreviveram melhor em função do horário ao qual o consumo da pizza ficou associado, noite, e em que normalmente é possível reunir amigos e familiares para compartilhar uma refeição em um ambiente descontraído e menos formal.

A ascensão da pizza e o decréscimo da cozinha italiana praticada até então na cidade, em detrimento de outros tipos de comida dita italiana que irão emergir na capital gastronômica, traduz as novas dinâmicas que se intercalam na vida urbana. A cozinha das cantinas "cheira a mofo", disse Fabrizio Fasano e talvez seja este o papel que lhes coube nesta nova fase.

A pizza lida melhor com as novas dinâmicas, é acessível e bem aceita em praticamente toda a cidade, fácil de consumir tanto em casa como fora dela. Pode ser mais refinada, tradicional ou simples, mas é também um prato global tamanha circulação que teve pelo mundo, difundindo uma italianidade menos presa ao território e mais ligada à ideia modernidade: é rápida, é fácil, é acessível, é próxima.

Introduzidas praticamente um século antes, a pizza e a cozinha italiana criaram seus próprios caminhos para se adaptar e conquistar o paladar local, porém mostram distintas formas de ser italiano. As pizzas e massas, segundo LaCecla (2007) foram os ícones da italianidade que tiveram como principais difusores as comunidades instaladas fora da Itália e cujo retorno ao país de origem consolidou-as como pratos determinantes da cozinha italiana ${ }^{201}$. Segundo o autor, a pizza, entretanto, seria um tipo diferente de comida, pois possui um caráter público mais acentuado que as massas ${ }^{202}$.

199 Warde (1997) fez uma análise das distintas forças em ação sobre as escolhas alimentares, mostrando como se articulam em especial quando o comensal come fora de casa.

200 Consultar Warde \& Martens (2000). Em Collaço (2003) proporciono uma classificação do comer fora em função dos eixos espaço e tempo, bem como as percepções em torno das refeições e as expectativas que as envolvem.

201 Helstosky (2004) afirmou algo semelhante.

202 Sobre esse assunto, consultar também Fischler (1990), ao comentar sobre os hambúrgueres e comparar sua popularidade com relação à pizza que, tanto ou mais que a comida norte-americana, está presente nos quatro cantos do mundo e ninguém diz que italianos são imperialistas. 
O que é curioso no caso paulista é que a cozinha italiana e a pizza começaram praticamente unidas, embora com o correr dos anos assumissem trajetos independentes. A pizza será a "cara da cidade", como disse Afonso Roperto. Essa percepção perpassa pelo imaginário da cidade e não é raro ouvir que "São Paulo tem a melhor pizza do mundo". Real ou imaginada, a pizza paulista reproduz uma série de justaposições até aqui analisadas. Italianidade, adaptação, progresso, família perpassam a incorporação da pizza como um hábito "do paulistano" e hoje se estende para além do consumo domingos à noite.

$\mathrm{O}$ fato de que boa parte dessa comida era produzida pelos nordestinos também levanta a questão do conhecimento e do envolvimento de quem produz o quê para quem. Como muitos nordestinos ficaram no lugar das mulheres e aprenderam a cozinhar com elas, os pratos de cantina sofreram mais com o estigma, ao contrário da pizza, de cunho mais popular e menos afetada pela produção pelas mãos de imigrantes nordestinos. Embora partilhando um lugar ao lado da cozinha italiana e ser servida em muitas cantinas, a pizza descolou-se da comida. Esse passo foi dado a partir dos anos 1970, quando há o surgimento de novos estabelecimentos dedicados somente a servir passas, sem massas nem outros pratos.

Esse processo talvez revele algumas questões importantes em torno da comida italiana e que tiveram especial importância em sua maior visibilidade na cidade. Além de ser uma comida relativamente fácil de ser reproduzida em casa, ela tampouco era totalmente inacessível para quem desejasse comer fora eventualmente entre as camadas médias. Os ingredientes eram bem mais acessíveis, sobretudo com a industrialização, e os italianos e seus descendentes já estavam bem incorporados à cidade, embora não seja possível saber o quanto consumiam dessa comida cotidianamente. É possível inferir pelas narrativas dos entrevistados que muitas famílias procuravam as cantinas para resgatar sabores preciosos da memória. A vida transcorrida nos bairros étnicos, o convívio com parentes e vizinhos, a comida eram elementos que falavam de uma italianidade já mais diluída, mas ainda viva.

Nos anos 1990 e 2000, ante os novos modelos do comer fora que começavam a pipocar pela cidade, esses empreendimentos fundamentalmente familiares se viram às voltas com novas demandas. O descolamento entre a realidade vivida, o projeto ambicioso, a crescente popularização do comer fora de casa fizeram com que a Capital Mundial da Gastronomia trouxesse más lembranças aos entrevistados. Os restaurantes irão ser transformados em novos espaços, irão expressar um novo comer pautado na individualidade, na disponibilidade de opções, no acesso mais amplo.

Os antigos restaurantes ficaram demodées ante os novos com decorações feitas por arquitetos conhecidos, equipamentos modernos e, muitas vezes, com algum nome de fama cuidando da cozinha, ou se não for o caso, com um chef capaz de legitimar o resultado. Assim, os números de 
restaurantes cresceram ${ }^{203}$, cozinha italiana não reinará mais entre uns poucos estabelecimentos em uma organização quase paroquial. Surge também uma variedade de estabelecimentos como bufês, por peso (os “quilos"), japoneses, vietnamitas, macrobióticos, naturais, vegetarianos, restaurantes italianos em moldes muito distintos de seus antecessores. Os proprietários de cantinas entrevistados disseram que nesse período sentiram como nunca o peso do nome no letreiro do restaurante, bem como a responsabilidade de manter o negócio vivo se transformou na principal preocupação das novas gerações.

Ante isso, soma-se que novos sabores começaram a ter grande repercussão pela cidade, como a disseminação da comida rápida nos anos 1980, seguida pela oferta de sabores mais exóticos, como comida japonesa, tendo seu boom nos anos 1990 ao lado de cozinha italiana considerada inovadora e verdadeira. Houve ainda, o surto de pequenos restaurantes dos anos 2000 com chefs estrelas, a chamada bistromania, uma alternativa mais acessível aos restaurantes ditos refinados, embora no Brasil fosse possível contá-los nas duas mãos ${ }^{204}$.

Como se pode notar, as linguagens se multiplicavam e começaram as dificuldades para os antigos empreendimentos familiares. São inúmeras ofertas disponíveis em um curto período de tempo e as antigas cantinas perderam apelo. Lentamente entraram em um processo de ostracismo que gerou uma série de reformulações, especialmente nos bairros do Brás e do Bixiga, onde muitos estabelecimentos deram seus últimos suspiros. $\mathrm{O}$ mesmo foi visto no centro, especialmente a partir do fim dos anos 1980, quando inúmeras empresas e secretarias estaduais saíram da região e reforçaram o processo de decadência.

É verdade que esse processo foi um fenômeno mais amplo e ilustra as dificuldades de constituir novos parâmetros da cozinha italiana e suas relações entre quem produz, distribui, prepara e consome a comida, afetando inclusive as concepções de uma refeição ideal ${ }^{205}$. Dessa maneira, o acesso facilitado a produtos, informações, comer fora irá produzir uma variedade de espaços e cozinhas, bem como eventos alimentares que até então não tinham sido testemunhados.

As cantinas eram lugares de famílias, comida farta, barulho, filas; as pizzarias também serão lugares de família, mas para jantar, inclusive uma refeição com mais possibilidade de ser realizada entre os diversos membros que o almoço. Além disso, com a crescente

203 Em uma consulta ao Sindicato de Bares, Restaurantes e Similares de São Paulo, atualmente a cidade conta com 12,5 mil restaurantes, 55 tipos de cozinha, 500 churrascarias, 256 restaurantes japoneses, 15 mil bares, 3,2 mil padarias que tiram 10,4 milhões de pãezinhos por dia; 1,2 mil pizzarias que vendem 1 milhão de pizzas por dia; 2 mil deliveries de pizza; e todos faturam juntos 5 bilhões de reais por ano. São Paulo já é a segunda cidade com maior número de restaurantes, só perde para Nova York.

204 Essa realidade foi copiada de um modismo norte-americano que surgiu em resposta aos preços considerados abusivos cobrados por alguns restaurantes cujos chefs eram estrelas de tal renome que acreditavam poder cobrar o que desejassem para que um comensal fosse servido em seu estabelecimento.

205 Murcott (1997). Também consultar Marshall (1995). 
dificuldade de deslocamento no espaço urbano, a preferência é por realizar as refeições próximas à residência ou local de trabalho, em espaços que reúnam outras atividades como os shopping-centers.

Por outro lado, se há o comer utilitário atendido por novas modalidades de restaurantes de comida rápida, há o fortalecimento da gastronomia como forma de expressar o desenvolvimento pessoal, uma ideia amparada na crescente individualidade que irá cercar o consumo, inclusive, alimentar. A novidade, variedade e quantidade constituem parte desse novo repertório que exige segurança e conhecimento ante o que está exposto. É preciso levar em conta, ainda, que o comer será uma das principais formas de lazer das camadas médias urbanas, multiplicando as combinações possíveis e suas percepções em um conjunto mais amplo de refeições consumidas por um comensal.

As transformações, então, não são imediatas. Estamos diante de um conjunto de novas regras em torno do comer que exigem maior atenção e controle. As cantinas e mesmo os restaurantes tradicionais de cozinha italiana não conseguiram acompanhar a crescente individualidade dos comensais e as novas alternativas que surgiam para comer fora de casa. Comer em uma cantina ou nos restaurantes italianos refinados que sobreviveram ao longo dos anos é vivenciar uma experiência antiga e muitas vezes de isolamento, pois em geral os salões estão vazios e as receitas permanecem fiéis às suas origens. Tudo parece estar caminhando em um tempo diferente daquele vivenciado na cidade cosmopolita, assim como a empresa familiar parece ter perdido seu dinamismo.

Não seria nem mesmo o caso de afirmar que são tempos de comunidade e de cidade, mesmo porque a formação dessa cozinha já estava inserida nos ritmos urbanos quando emergiu. $\mathrm{Na}$ verdade, a decadência está associada a uma comida que não representa mais os valores de um determinado grupo e tampouco soube estabelecer um diálogo com os novos tempos, talvez a única exceção a família Fasano, embora tenha passado por vários percalços até acertar o passo. Os demais interlocutores de alguma forma ou de outra sofrem para sobreviver e suas principais memórias se retêm nos momentos mais auspiciosos de seus estabelecimentos.

A hierarquia social adquiriu contornos mais complexos e é expressa sob condições em que o acesso à variedade, quantidade e novidade desempenha um papel central, de maneira que não só a distribuição de conhecimentos é desigual, mas também seu acesso. Na capital gastronômica esse ponto fará com que as cantinas e os restaurantes refinados dos anos 1950 e 1960 acabem ocupando uma mesma classificação, associados ao velho, ao antiquado.

O discurso do saudável, a negação da obesidade e um aumento da importância em torno da estética, traduzida na "etiqueta" do comensal e na apresentação dos pratos, assim como na combinação de ingredientes em receitas são ingredientes de um novo controle corporal e social. A velha cozinha de cantina ainda precisa lutar contra mais esse estigma, o de ser uma comida 
pesada, antiquada e que também se estende aos restaurantes italianos mais tradicionais como Ca’D’Oro, Tatini, Gigetto.

Contudo, é curioso notar que, na Rua Avanhandava, para onde se mudou o Gigetto nos anos 1960, houve um novo surto de apropriação no início dos anos 1990. Foi inaugurado o restaurante Famiglia Mancini que, apesar de seguir a cartilha das cantinas, comida farta e bom preço, conquistou uma vasta clientela que não se incomoda em aguardar horas por um lugar para sentar. Esse sucesso, segundo uma entrevista dada por Walter Mancini na TV Cultura, era graças à parceria com o mundo teatral. Servia o elenco em troca de divulgação.

Essa estratégia não soa muito distante ao que era feito pelo Gigetto quando teve seu apogeu. No entanto, o que pode ter implicado em diferentes apropriações e percepções com relação ao velho concorrente foi que apesar de servir uma comida bastante próxima, oferecia um bufê de antepastos e um preço condizente com o tipo do estabelecimento. Ana Paula Lenci se percebe essa diferença, não a menciona e atribui ao processo de revitalização do centro uma centelha de esperança para reavivar os tempos áureos de seu restaurante, embora ainda não sentidos da maneira como ela acalenta,

[...] Independentemente dos famosos, todo mundo conhece o Gigetto [...]. Com a revitalização do centro, houve uma revalorização da cultura, houve um retorno às tradições, hoje com a rapidez das informações temos muitos valores perdidos. Mudou a atitude do comer à mesa, hoje temos muitas mesas familiares, muito mais que antes quando predominavam mesas de amigos e colegas de trabalho.

$\mathrm{Na}$ verdade, o restaurante Gigetto se alimenta de uma realidade que não irá se repetir e que seu concorrente percebeu. Continuam os grupos de amigos, as famílias frequentando os restaurantes, mas não oferece alternativas distintas e preços considerados apropriados para o restaurante que, para muitos, já está decadente.

Os encontros pessoais do Gigetto cederam espaço a outras sociabilidades que o restaurante Famiglia Mancini soube interpretar melhor. A comida está inserida em um registro conhecido, de cantina, mas não precisa mais do vínculo étnico para se sobressair. Essa proximidade foi diluída à medida que a cozinha italiana ganhou reconhecimento na cidade e é sabidamente reproduzida por mãos além dos italianos.

A novidade, como se vê, tampouco é tomada sob um viés específico, multiplicada pelas novas interações que se moldavam a novos estilos de vida, especialmente de camadas médias urbanas. Na capital gastronômica é que será observada uma acentuada valorização, em parte uma resposta às dinâmicas que se constituíram em torno do consumo, já que as opções para comer fora de casa começaram a se expandir e aumentar as dificuldades de escolher o quê comer, quando, com quem, como. 
Segue-se à novidade, o fato de dispor de uma ampla variedade de restaurantes e em boa quantidade, de maneira que a decisão individual toma fôlego. É evidente que esta é apenas uma das pontas que compõem o tecido que ampara as escolhas do comer, mas há, sem dúvida, uma estrutura de refeições imaginária ou real que será responsável pela ação ${ }^{206}$. Os restaurantes serão apropriados em virtude dessas articulações e, apesar da cozinha de cantina ser conhecida e gerar segurança pela proximidade, seu crescente desprestígio foi em parte resultante do desvio da legitimação da cozinha italiana. Se antes eram as mammas, agora são os chefs, críticos de gastronomia, livros, programas de TV.

Esse aspecto foi muito debatido com os entrevistados que acreditam que parte da decadência vivida pelas cantinas está assentada na consciência, ou na falta de, ao comer. Segundo Ângelo, a queda de seu movimento é devido ao envelhecimento de sua clientela e ao desinteresse das novas gerações em seguir costumes familiares. Esse é o peso de ser tradicional e assim como ele, outros interlocutores se depararam com essa questão. Ângelo disse:

\begin{abstract}
As pessoas vinham antes e não se preocupavam com o que estavam comendo, vinham por prazer, para comer, trazer a família. Agora não, tudo mudou. Todo mundo está preocupado com a forma, ninguém quer engordar. Isso atrapalhou muito [...] O tempo passa para todos, as coisas mudaram, não pode come [...] As mudanças acontecem, mas eu tenho uma coisa conservadora que o Fasano não tem, o Cilentano tinha, mas outras simplesmente não tem.
\end{abstract}

Refletindo sobre as suas condições e de outros proprietários de cantinas, Ângelo Luisi se vê como alguém preocupado com a tradição, o que não acontece com outros donos de restaurantes. Para ele, o fato de ser conservador, não mudar o cardápio abruptamente ou adicionar "invencionices" é que dão consistência ao seu trabalho. Entretanto, a cozinha sem personagens ilustres fez que sua comida perdesse valor ante os comensais, hoje restritos a um punhado de curiosos, um e outro cliente antigo. Para os entrevistados esse momento representa um impasse, mudar ou manter pratos, deixar a decoração como está ou mudar, são temas de discussões internas que perpassam, sobretudo, as conversas entre gerações.

A invencionice, como também gosta de dizer João Donato e Antonio Carlos é um atributo específico dos chefs $s^{207}$, "arrogantes e presunçosos, especialmente esses jovens que saem de fraldas da universidade e acham porque fizeram estágio com Atala já sabem tudo.", disse Antonio Carlos que falou sobre mudanças:

Eu introduzi o macarrão aos frutos do mar, veja bem. Não inventei, eu apenas usei meu conhecimento e o de cozinha italiana para fazer um prato que era comum no norte da Itália, mantendo fidelidade à Itália. Não sou chef, sou

206 Ver Douglas (1975), Murcott (Op.Cit.) e Warde (Op.Cit.).

207 Essa característica é discutida por Revel (1996), Mennell (1996), Goody (1982). 
restaurateur $^{208}[\ldots]$ Ninguém lembra dessa gente antiga, ser chef são 40 anos de profissão e todo chef sabe o quanto é difícil trazer o cliente uma ou duas vezes por semana ao restaurante.

Ser chef aos olhos de Antonio Carlos é seguir modismos que acabam circulando com muito mais intensidade nos dias atuais. Em São Paulo não existiam chefs, a não ser estrangeiros e ultimamente os que são formados pelos cursos técnicos de algumas universidades. Como se viu a base da cozinha do restaurante era um conhecimento que circulava entre mães e avós, com o correr dos anos esse saber foi transmitido aos personagens que ficaram no lugar das mammas, os cozinheiros de origem humilde e nordestina e que foram os personagens principais das cozinhas até pouco tempo na cidade.

Estes foram desbancados a partir do momento que a cidade se vê de fato como Capital Mundial da Gastronomia e as linguagens em torno da comida se multiplicam, quem produz deve ser um chef e quem consome deve reunir elementos necessários para compreender a comida. Nesse caso, fortalecem-se os jornalistas, críticos e gourmets, estes últimos reconhecidos como apreciadores de boa comida e de boa bebida. As mudanças ainda apontam outros aspectos, segundo Giovanni Bruno:

\footnotetext{
Na Europa você tem muitos restaurantes familiares, aqui todos aderiram ao estilo francês, um serviço fantástico, e São Paulo é merecedor, é o lugar do mundo onde mais pessoas comem fora. A rapidez está acabando com os pratos tradicionais. [...] Antigamente era o estômago que comandava, hoje são os olhos [...] E há também a influência da mídia e o fato que a família não escolhe onde comer, hoje são os filhos que comandam [...] as crianças têm voz.
}

O interlocutor percebe que as famílias estão assentadas em novas bases, que os restaurantes se rendem ao culto do rápido, que hoje há preocupação com o visual e a mídia tem certo alcance. A adesão ao serviço de salão mais refinado influenciou também a decadência, já que não era um serviço rápido e tinha como principal instrumento de trabalho o carrinho com fogareiro que caiu em desuso, especialmente nos restaurantes que começaram a surgir nos anos fim dos anos 1980. Os restaurantes que ainda o utilizavam ficaram ultrapassados, "parados no tempo", como disse Fabrizio Fasano, pois "é da cozinha que a comida deve sair, é lá que está o chef."

Dessa forma, não era somente a comida que ficou com ranço de antiquada, a forma como era servida também. E foi a partir dessa constatação que muitos estabelecimentos tentaram refazer o seu percurso, alguns com melhores resultados que outros. Na realidade, a capital gastronômica impunha novos ritmos que, muitas vezes, não condiziam com os princípios que os proprietários

208 Restaurateur é o nome dado ao proprietário de restaurante derivado da ideia de restaurar que inicialmente esteve presente entre os primeiros restaurantes. Estes serviam caldos que restauravam as forças e energias e eram freqüentados especialmente por pessoas doentes. Para uma história completa dessa concepção, consultar Spang (2000). 
desejavam manter em seus estabelecimentos. Confiavam em sua qualidade e em sua tradição, mas não estimaram o impacto que guias e chefs de cozinha teriam sobre os restaurantes.

Giovanni Bruno estava atento às transformações e percebeu o impacto que as novas linguagens tiveram e se associaram à nomeação da cidade como capital gastronômica que, ainda, contou com o impulso do fenômeno da globalização. Ele disse que:

\footnotetext{
O mundo está integrado em São Paulo, as famílias trouxeram suas comidas, a cidade é gastronomicamente do mundo. Qualquer comida chique tem, empada, esfiha, espaguete. Isso é uma grande felicidade. È uma grande metrópole gastronômica, esse prêmio é justo (ele se referiu ao titulo de Capital Mundial da Gastronomia como prêmio) e as pessoas sabem de São Paulo pela nossa abundância, pela nossa quantidade de opções.
}

No entanto, menos que a globalização, ele entende que a convergência de distintos grupos na cidade foi o que permitiu criar os pilares de uma capital gastronômica. A verdade é que a diferença entre grupos sempre esteve presente, o que mudou foi tomar a cozinha de um país como uma manifestação cultural que, uma vez manejada apropriadamente, daria suporte ao desenvolvimento pessoal, cujo sentido é extremamente importante em sociedades cada vez mais individualizadas ${ }^{209}$. Sem dúvida é uma visão simplificada da cozinha, embora circule com bastante força no imaginário popular que contou, ainda, com o estimulo ao turismo ${ }^{210}$. Essa relação, contudo, encerra uma forma engessada e peculiar de encarar a diferença, reforçando estereótipos associados ao encontro cultural e que a comida supostamente sustentaria.

Essa questão está relacionada à dimensão que a cultura toma em certas retóricas, bem como se funde às imagens do que constitui um país e sua delimitação espacial. É uma relação que toma a cultura como própria de um local e uma vez deslocada de sua delimitação original, poderia ser recomposta em outro espaço. Pouco se leva em conta a dimensão temporal e os próprios arranjos necessários para a manifestação cultural afastada de seu contexto original. $\mathrm{Na}$ cozinha essa equação tem resultados variáveis, especialmente quando o foco é nos restaurantes. Alguns serão mais autênticos que outros em função do diálogo entre os distintos planos que vão considerar, ainda, os legitimadores dessas cozinhas.

A legitimidade de uma cozinha dependerá, então, do grau em que se formula um conjunto de símbolos que dizem respeito a determinado país e criam um sentimento de reconhecimento. A cozinha italiana que veio com os primeiros imigrantes não dispunha de uma representação nacional, mas criou uma trajetória particular na capital paulista. Contudo, anos mais tarde ameaçada pelo imaginário de uma cozinha italiana que circularia com o fenômeno da globalização e que trouxe impactos para os restaurantes paulistanos.

\footnotetext{
209 Hannerz $(1992,1998)$.

210 Consultar Long (2003) e Hjlager \& Richards (2002).
} 
Como todo processo que busca firmar uma identidade, alguns elementos seriam descartados e outros tomados com maior vigor. No mundo da capital gastronômica essa questão adquire um novo peso, as cozinhas que já estavam presentes na capital gastronômica e que não detinham grande visibilidade, passaram a chamar a atenção e reforçar a imagem de diversidade. Desse modo, não se trata somente de uma questão de imigração, mas de como esses grupos se entranham localmente.

Os italianos tiveram um papel acentuado porque além de abrirem com mais flexibilidade seus sabores para além das fronteiras étnicas, empunharam as armas do progresso e foram civilizadores do gosto paulistano, como diversos interlocutores afirmaram. Em parte, o descaso atual com relação aos restaurantes e cantinas mais antigos é justamente pela falta desse reconhecimento e que se acentuou quando ao longo dos anos de Capital Mundial da Gastronomia surgiram restaurantes italianos sem quaisquer vínculos étnicos e dizendo servir uma cozinha italiana verdadeira, uma vez que reproduziriam a cozinha praticada atualmente na Itália.

Retoma-se a questão da relação tempo, espaço e cozinha nacional. A cozinha italiana local seria menos verdadeira que a praticada atualmente na Itália e, assim, seria mais um ponto desfavorável às cantinas e restaurantes refinados surgidos nos anos 1950 e 1960. Para os da velha guarda é apelo comercial porque esses novos restaurantes não têm tradição, vínculos étnicos, o chef inventa o que quer. Os novos restaurantes olham com desprezo para os antigos, pois preparam uma comida "leve e perfumada", não ignoram os caminhos atuais da cozinha na Itália e os restaurantes, em geral, possuem um ambiente moderno, bem como um serviço compenetrado com os anseios atuais.

Os imigrantes e seus descendentes que trabalham com restaurantes desejam manter elementos que reforcem sua cozinha como italiana, mas se sentem ameaçados pelos novos estabelecimentos que, muitas vezes, não tem vínculo algum com a Itália a não ser sua proposta. Além disso, há também a oferta de comida italiana em outros restaurantes que não somente especializados nessa cozinha, facilitando o acesso e dando novos tons ao imaginário, como aqueles que servem refeições rápidas, os fast-foods.

Essa disputa também encerra uma negociação de italianidades. A comida como expressão da imigração e sua contribuição agora se debate com novas linguagens vindas não pelas mãos italianas, mas pelas mãos de pessoas que legitimam a comida de uma forma muito diferente e, não raro, feita por descendentes que vão à Itália e trazem as novas linguagens. A mamma e o seu saber serão confrontados pelo saber profissional, pelo saber legitimado pelos cursos, viagens, informações.

É o confronto entre o típico e tradicional da cozinha italiana, embora paulistana, e o autêntico, representado nos restaurantes recentes. São distintos ritmos da cidade representados nos espaços que servem essa comida. Os olhares se direcionam para direções opostas, um vê o passado e 
sua contribuição, outro vê o futuro pelos restaurantes como reforço da vocação cosmopolita da metrópole. A fama que a cidade construiu não foi pela excelência de sua cozinha local, mas pela quantidade de estabelecimentos que oferecem culinárias de vários países. A tradição perde espaço para o novo, para a variedade e para a quantidade.

A cozinha italiana praticada na cidade é fruto de uma relação coerente pautada entre cidade e italianos. Se a cozinha italiana perdeu italianidade frente à Itália, ganhou esse peso entre os paulistanos que a tomam como uma particularidade da cidade. Há uma ruptura entre espaços e tempos para falar de uma cozinha italiana na cidade de São Paulo, não se trata de ser mais verdadeiro ou não, apesar de que na percepção do comensal essa ideia persiste. São diferentes caminhos percorridos por essa cozinha até alcançar os restaurantes.

Como espaços de novos sabores, os restaurantes contemporâneos não se limitam ao vínculo étnico, de origem ou de classe. A cozinha busca legitimidade na produção dita profissional e se destina a um comensal mais informado. No entanto, se o consumo de certos alimentos gerava as condições necessárias para diferenciar, é preciso olhar também para o reverso desse processo. Ir a um restaurante pode não só falar de distinção, mas também de encontrar meios de ser igual. Ao consumir algo dentro de uma gramática similar se está em sintonia com regras da ordem social e, embora as escolhas sejam individuais, o sentido é coletivo e as tensões que isso representa vão sendo administradas em diversos planos ${ }^{211}$.

O Jardin di Napoli, restaurante onde trabalha Adolfo Scardavelli, abriu um estabelecimento de comida rápida, um fast-food, na praça de alimentação de um shopping localizado a uma quadra de sua localização original e, inclusive, mantendo o mesmo nome. Adolfo contou sobre o empreendimento que:

[...] é para atender a clientela que não vem aqui [...] é o pessoal que vai no shopping, está com pressa, quer ir ao cinema, sair com as crianças pequenas mas não quer ir em restaurante, acha formal demais. [...]Quem trabalha também passa por lá, é mais rápido que aqui, se bem que as porções lá (no shopping) são bem menores, não é para a família, mas os preços também são melhores, então a pessoa pode comer o que está com vontade, não precisa dividir como acontece aqui.

A comida tradicional italiana servida no restaurante foi para as mesas das praças de alimentação e se adaptou às dinâmicas do fast-food. É um novo processo em que comer fora de casa se torna mais acessível e a comida italiana, mesmo alocada em uma chave que dialoga com o tradicional e o familiar, é transposta para um novo espaço sem perder totalmente suas particularidades, embora sem ignorar outras. A cantina não consegue abarcar os arranjos sociais que uma metrópole oferece.

211 Para uma instigante discussão sobre esse assunto, consultar Douglas \& Isherwood (2004). 
Outra saída para conseguir manter viva a cozinha italiana local foi transformá-la em patrimônio cultural, assunto que será abordado adiante, um processo em que estabelecimentos do Bixiga se engajaram para acompanhar as mudanças da Capital Mundial da Gastronomia sem perder elementos que consideravam importantes. Nesse caso, está Afonso Roperto que encontrou na exploração turística um filão para introduzir novos sentidos ao estabelecimento e à comida ali servida. Atraindo uma clientela basicamente de fora da cidade, seus visitantes vão para conhecer "o Bixiga tradicional, a influência italiana e conhecer sua comida". Assim, para os que vêm de fora a cozinha do Bixiga é o resultado da influência italiana, para os locais a percepção é outra. $\mathrm{Na}$ verdade, o que está em jogo é perceber que comer não é cultura, como Douglas (1975) apontou, mas é em sua prática que emergem sentidos sustentados por dinâmicas sociais e culturais.

As cozinhas de cantina confrontadas com as cozinhas italianas ditas refinadas dos novos restaurantes das décadas de 1950 e 1960 se unem e irão dialogar com restaurantes de cozinha italiana rápida, restaurantes de uma cozinha italiana dita contemporânea, restaurantes que servem pratos de inspiração italiana sem necessariamente servir somente esse tipo de culinária, além da pizza.

As cantinas e restaurantes tradicionais, muitos ainda com forte estrutura familiar, precisaram incorporar essas novas dimensões. E como foi possível notar, alguns não conseguiram acompanhar o ritmo das mudanças, apenas perduram à custa de muito esforço e dos resíduos que restaram de seus tempos de glória. Como o próprio Antonio Carlos Marino comentou, "não é fácil ficar 100 anos de pé [...] trazendo cliente para o restaurante com frequência”, saber corresponder aos ritmos urbanos nem sempre é uma medida fácil de ser adotada, especialmente entre aqueles mais conservadores e apegados a uma ideia de tradição.

Outro aspecto central foram as novas apropriações urbanas, a decadência do centro, as novas dinâmicas globais em contato com o local ordenaram a comida sob outros padrões, bem como organizaram as lembranças sobre parâmetros que acentuam o saudosismo e certa amargura pela

passagem de tempos que não voltam mais. É o peso da tradição que abala o reconhecimento desses estabelecimentos bem como deixa o futuro duvidoso.

\section{Gastronomia, Consumo e cidade - embates ente o tradicional e o novo}

As mudanças nas cidades brasileiras, sobretudo as capitais, não foi um fenômeno isolado, mas teve desdobramentos em várias áreas do cotidiano urbano, além das questões de violência e medo que concentraram muitas atividades antes feitas na rua em centros comerciais, os shopping-centers, bem como muitos moradores se mudaram para condomínios afastados para garantir seu bem-estar. 
O centro de São Paulo ficou associado à violência, à desordem, às drogas e repercutiu na forma de morar, trabalhar, estudar e se divertir. Os condomínios fechados destinados às camadas médias foram uma alternativa para escapar à incerteza das ruas, no entanto firmando isolamento e distância das regiões centrais que até então concentravam o comércio, o divertimento ${ }^{212}$. Foi quando evitar situações de risco e procurar experiências previsíveis passou a predominar no imaginário das camadas médias urbanas e os grandes centros comerciais, como os shoppingcenters, vieram para atender aos novos anseios ${ }^{213}$.

Além das opções que surgiam para comer fora, como os restaurantes para servir comensais no horário do almoço com uma comida muito próxima ao domínio doméstico, os self-service que utilizavam o sistema de bufê (preço fixo) ou por peso (os quilos) ${ }^{214}$, transformações sociais afetavam o comer. Nesse sentido, as mulheres eram absorvidas pelo mercado de trabalho, deixando os encargos de alimentação a auxiliares domésticas ou, quando não tivessem alguém para ajudar, recorriam ao uso de produtos congelados, bem como serviços de entrega (deliveries), prioritários para organizar a alimentação doméstica.

Ante isso, atualmente nos grandes centros urbanos brasileiros, comer fora de casa corresponde a $32 \%$ das refeições realizadas, conforme dados fornecidos pela ABIA Associação Brasileira das Indústrias de Alimentação - dado fornecido pelo seu relatório de 2006 sobre o mercado de food service ${ }^{215}$. É mais indicativo de mudanças ainda se considerarmos que na década anterior, aproximadamente $20 \%$ das refeições transcorriam fora de casa, número ainda menor nos anos 70, quando atingia apenas 11\%. Paralelamente, o número de restaurantes cresceu. Em 1980 o Brasil contava com 320.000 restaurantes; em 2003 já eram 904.000, um salto de 199\%, segundo dados da mesma associação. Outro fator indicativo é o tempo dedicado ao preparo de refeições, em 1971 esse tempo era de duas horas por dia, e em 1998 já tinha sido reduzido para 15 minutos, mantendo-se no mesmo patamar em 2005.

Comida rápida já era conhecida no Brasil, no entanto eram refeições oferecidas em estabelecimentos modestos que, em geral, serviam o prato feito (PF), além de hambúrgueres e batatas fritas vendidas em lanchonetes, alimentos fornecidos em barracas ou vendedores ambulantes e as pizzas, embora encontradas em sua maioria nas pizzarias. Mas, é também

\footnotetext{
212 Caldeira (2000).

213 Para essa discussão, consultar Frugoli Jr. (1989).

214 Para uma discussão mais ampla sobre o assunto, consultar Abdala (2003). Pessoalmente me lembro de um restaurante que fez sucesso no início dos anos 1980 e que servia um bufê somente de saladas, cobrando preços exorbitantes, localizado na Rua Oscar Freire, o Salad's, mas que tinha filas imensas todos os dias à sua porta. Lamentavelmente não encontrei nenhum artigo sobre esse estabelecimento.

215 Food Service é o fornecimento de mercadorias e serviços pela indústria aos estabelecimentos públicos ou privados que fornecem alimentação aos consumidores que procuram refeições fora de seus lares, segundo definição da mesma associação.
} 
quando se introduz o McDonald's e seu conceito, afetando a forma de oferecer refeições de modo mais amplo ${ }^{216}$.

Contudo, se os restaurantes de comida rápida já davam seus primeiros ensaios em distintas localidades, era preciso reunir outros fatores para constituir as praças de alimentação em centros comerciais, bem como ampliar a oferta de restaurantes. Industrialização, homogeneização, mercado de massas e urbanização foram alguns dos componentes que incentivaram o desenvolvimento de restaurantes de comida rápida, bem como outras alternativas de comer fora de casa, refazendo o percurso de ocupação dos restaurantes que passa a se dispersar por distintos bairros, inclusive residenciais.

$\mathrm{Na}$ esteira desses arranjos, o hábito de comer fora de casa adquiriu maior presença entre famílias de camadas médias, fomentando um consumo maior de refeições fora de casa que antes estava restrito a um punhado de estabelecimentos ${ }^{217}$. A cidade começa a crescer para além dos limites do centro. As escolhas simplesmente se multiplicavam, não só em termos de quantidade, mas também nas constantes novidades e variedade de alimentos, restaurantes, tipos de refeições.

A comida entra em cena e não é mais parte de um evento alimentar, ela também é assunto de rodas, de programas, de revistas, de livros. Os cozinheiros foram ganhando visibilidade, se nas cantinas e restaurantes tradicionais eram leais funcionários e pouco apareciam, na Capital Mundial da Gastronomia são alçados a estrelas. Circulam pelos salões, mostram seu conhecimento em pratos e explicações e não se intimidam frente às câmeras e jornalistas, ao contrário, buscam sempre ser notícia. Os comensais também se defrontaram com novas articulações, menos tempo para comer durante a semana, redução de refeições em família, um leque muito mais amplo de opções, escolhas mais individualizadas.

Os estabelecimentos da velha guarda são incorporados ao novo rodamoinho gastronômico, urbano e cosmopolita, mas não sem ferimentos. Os interlocutores ressaltaram sua influência, seu conhecimento e seu trabalho, mas a capital gastronômica não correspondeu às expectativas.

216 Na Europa os caminhos trilhados foram outros, embora restaurantes servissem refeições rápidas desde o começo do século XX, como sugere o caso analisado por Allen (2002) na cidade de Berlin. Ali já era possível comer refeições a preços baixos, padronizadas entre filiais de um mesmo restaurante, Aschinger. A análise da trajetória desse estabelecimento revelou que possuía vários pontos espalhados pela capital alemã, seguindo o mesmo modelo: comida produzida em larga escala, servida de modo igual em todos os estabelecimentos, preparadas em uma cozinha central e distribuídas diariamente. Todos os restaurantes seguiam o mesmo tipo de decoração, assim como as garçonetes usavam os mesmos uniformes inspirados nas roupas tradicionais do sul da Alemanha.

Na Inglaterra, conforme Oddy (2003), as cafeterias e lojas de chá eram também estabelecimentos populares servindo milhares de refeições rápidas e baratas, especialmente para as pessoas que se encontravam de passagem, em geral instaladas privilegiadamente ao lado de estações de trem ou bondes. Outros locais populares eram as lojas de peixe e batatas fritas, as fish-and-chips shops, além dos estabelecimentos da rede Lyons and Co. Ltd. que atendiam inúmeros trabalhadores apressados, servindo desde café da manhã aos elaborados chá das cinco.

217 Para uma discussão mais ampla, consultar Warde \& Martens (2000) sobre o hábito de comer fora analisado em um amplo estudo na Grã-Bretanha. 
Ao contrário, permitiu que inúmeros "aventureiros" entrassem em cena, diluindo cada vez mais a importância de seus estabelecimentos. Hoje são um reflexo pálido do passado e lembrados como "lugares pitorescos" de uma cena urbana já distanciada, como disse Paola:

\begin{abstract}
O padrão da culinária italiana é variável, tem coisa boa e coisa mais ou menos, o título (Capital Mundial da Gastronomia) para São Paulo é merecido, mas também trouxe muita gente aventureira. Tem muito entra e sai de gente do mercado, muita propaganda, abre e fecha [...]. As pessoas estão começando a enxergar o que é gastronomia no Brasil, a gastronomia começou há 10 anos. Para ser chef tem que saber história, saber comandar, preparar [...]. Existem segredos na cozinha e as pessoas apenas copiam o conceito e aí vem para tirar nossos clientes.
\end{abstract}

A interlocutora deixou entrever que os tempos são outros, em vários sentidos. A comida italiana, apesar de reconhecida e apreciada na cidade, aparece em versões melhores e piores, especialmente porque se vendo como capital gastronômica, a cidade se abre ao experimento. Seus avôs quando fundaram a pizzaria ganharam reconhecimento "pelo trabalho, o marketing foi uma consequência desse trabalho", ou seja, a concorrência que explodiu nos últimos tempos não partilha da mesma trajetória, da mesma qualidade que seu estabelecimento. Vive mais de aparência e de mídia, pois ela continuou,

\footnotetext{
Nem sempre o melhor do mercado é o que se destaca na mídia, estabeleceram como um conceito importante e manter o que fizeram. Eu herdei parte disso, e tenho responsabilidade. Só que hoje o mercado é cheio de gente desonesta.
}

Em resumo, tanto ela como outros interlocutores crêem em sua qualidade, mas se sentem desfavorecidos pela mídia e opinião em geral. No seu caso, os negócios vão relativamente bem, mas se sente incomodada com a situação gerada pela capital gastronômica, já que para fazer jus ao nome é preciso ter oferta, não importa de que maneira. Foi o imaginado agindo sobre o real, pois ao se constituir essa identidade, precisou ser alimentada pelos ideais que a conceberam.

Concomitantemente, a capital gastronômica se aproveita também das intensas interlocuções entre o global e o local, acionadas pelas dinâmicas da globalização. No caso da comida italiana emergiu, como se viu, um novo contraste que irá predominar principalmente a partir dos anos 1990. A velha cozinha de cantinas e restaurantes tradicionais unidas frente à cozinha italiana que passava a ser praticada em restaurantes e referida como a verdadeira cozinha italiana. Nesse caso, estabelece-se uma nova abertura para repensar a italianidade, principalmente pelas mãos de seus descendentes, tanto a nível local, como em termos de país, Itália, que esbanja condições econômicas relativamente boas e é parte da Comunidade Européia.

Nesse sentido, a imigração adquire mais proeminência do que nunca é será parte de um projeto e ações para a comemoração dos 450 anos da cidade, que pretende articular os distintos 
grupos que compuseram a população paulistana a fim de potencializar encontros. No texto desse projeto, os seus principais objetivos são:

- Criar uma marca forte da cidade que possa servir como referência turística, de atividades culturais e participação popular;

- Criar um canal de comunicação e participação permanente entre as comunidades estrangeiras, organizadas ou não;

- Preservar e cultivar a memória da imigração e dos processos migratórios internos e, com isso, a história da cidade, por meio de estudos, pesquisas, debates e diversas formas de divulgação a respeito da influência cultural e social dos diversos fluxos migratórios na cidade;

- Promover a participação das comunidades de origem estrangeira no intercâmbio e na cooperação internacional, assim como das comunidades de migrantes internos na aproximação com outras unidades da federação brasileira ${ }^{218}$.

A comida será um dos meios em que essas influências se fizeram notar e é tomada como um traço cultural que expressa um determinado grupo ou país. A pluralidade com que essa comida se oferece na cidade a transforma em uma verdadeira metrópole cosmopolita, embora algumas cozinhas tenham estabelecido laços mais estreitos do que outras surgidas apenas em restaurantes. São Paulo tampouco valorizou sabores locais e tampouco regionais do Brasil, como o fez Lyon e outras capitais gastronômicas, como Paris.

$\mathrm{Na}$ verdade, ao ignorar as cozinhas de outras regiões e valorizar a imigração como traço de progresso, a cidade estabeleceu um lugar diferenciado para si ante outros centros urbanos nacionais. Conquistou essa posição pelo fato de ter congregado diferentes grupos que a fizeram plural e diversa, civilizando e educando a população local o que sugere, de maneira subjacente, houve a influência maior do branco. Essa retórica foi apropriada pelos imigrantes, como os italianos, e se fez notar em sua cozinha.

Os imigrantes descolaram sua cozinha de suas raízes e hoje precisam conviver com esse dilema, embora sem sua colaboração a capital paulista não teria reunido os elementos necessários para formular sua imagem como Capital Mundial da Gastronomia. Nesse processo, a influência das mulheres na construção dessa cozinha não foi nem sequer reconhecida, salvo alguma ou outra exceção.

O desaparecimento da valorização do trabalho feminino na cozinha está profundamente associado à distinção e à divisão de trabalho. O doméstico é do universo feminino, o público, do masculino. A cozinha doméstica é entendida como repetitiva e monótona, a cozinha do restaurante

218 Retirado da página: http://milpovos.prefeitura.sp.gov.br/interna.php?com=38\&lang+1\&id=639, em 22/09/2005 
inventiva e desafiadora, o que na verdade não condiz com as condições reais. A ausência de um ingrediente e a posterior substituição pode criar resultados criativos tanto em casa como na cozinha profissional, do mesmo modo que a repetição de tarefas é uma das principais formas de organização de trabalho na cozinha. Na verdade, como disse Revel (1996), “(....) infelizmente, há mais falsos grandes cozinheiros que verdadeiras boas cozinheiras" (Apud: 211).

Em parte, é preciso considerar que a ascensão dos chefs em São Paulo é ainda recente e pode ter se emaranhado de forma mais resistente na construção das memórias dos interlocutores, valendo-se do fato de uma divisão já existente entre tipos de atividades consideradas femininas e tipos de atividades consideradas masculinas. Na verdade, os atuais proprietários de restaurantes antigos estão valorizando sua trajetória e seu poder civilizador e tentam encontrar saídas para sobreviver. A tradição que evocam não se pauta na mulher, mas em sua trajetória como imigrantes e como responsáveis por introduzir a possibilidade de ampliar o repertório culinário local.

Nesse caso, Afonso Roperto não ignora o papel das mammas e ainda o valoriza ao adotar uma estratégia para atrair clientes para seu restaurante nestes novos tempos. Não titubeou em organizar alguns arranjos com agências de turismo especializadas em trazer turistas para "desfrutar a vida cultural de São Paulo, e na programação inclui uma visita ao Bixiga e ao restaurante provar as delícias da mamma". A maioria dos viajantes chega do interior para ir a um bom espetáculo e em seguida jantar e nesse arranjo entre interlocutor e agência a ideia é oferecer ao turista uma experiência tradicional, de maneira que irá realizar uma refeição em um restaurante tipicamente italiano, em um bairro também tipicamente italiano, o Bixiga.

Esses novos arranjos são bem observados por Giovanni Bruno:

\begin{abstract}
Antigamente eu atendia desembargadores, empresários, famílias inteiras. [...] Fui escolhido pela Globo (rede de televisão) para protagonizar um programa sobra os cem anos da imigração italiana no Brasil [...] Hoje minha família, mulher, filha e neto está no Brasil. Minha vida é aqui, mas com o tempo, meu nome seria continuado pelo meu neto, mas e o restaurante? [...] Eu considero o restaurante minha casa, um ponto de encontro sem a minha presença tenho a impressão de que algo vai faltar.
\end{abstract}

O interlocutor não ignora as mudanças e tem plena consciência de que seu restaurante sobrevive em função de sua história e personalidade, mas coloca em dúvida se essa cozinha italiana que pratica terá lugar nas próximas gerações. Afonso Roperto percebeu algo parecido em sua cantina, não só a comida que as pessoas procuram mudou, mas também a forma como as refeições são conduzidas. Planejar o futuro nos moldes praticados pelas experiências anteriores torna-se inviável.

Você pega a curva de faturamento, mas é diferente da sensação de excelência. São ciclos, meu avô teve sucesso e quando começou a tentar novidade, a cantina caiu. Meu pai entrou e construiu o prédio, a cantina estourou e a família 
ganhou orgulho novamente. Agora meu sentimento é que chegou minha vez, eu preciso renovar e por isso coloquei internet, vinhos etc.

Novidade e tradição parecem travar um embate, mudança e continuidade se colocam constantemente como forças opostas agindo sobre as decisões dos proprietários de restaurantes. Se por um lado há maior curiosidade em novos sabores, o tradicional remete ao familiar, ao nostálgico, ao improvisado e autêntico. Entretanto, é interessante perceber que essas perspectivas não são excludentes, na verdade são resposta ao processo de globalização que diz respeito a uma seleção de elementos para formular identidades ${ }^{219}$.

A consulta às mammas ou nonnas são formas que tentam resgatar um modelo já bastante dilacerado de cozinha e que se não se inspira na tradição, agora parece que irá referendar os sabores conhecidos, de casa. Não é um reconhecimento da colaboração feminina, mas saber que a partir de seu saber é possível recuperar sabores que se dizem "do coração" e que alimentam a alma ${ }^{220}$. Na verdade não é um reconhecimento da contribuição feminina, mas o uso de um conhecimento em uma dinâmica distinta, comercial, para tentar recuperar um espaço perdido.

Foi por estar lidando com essas questões que Afonso Roperto ficou muitos anos longe do restaurante com medo de se sentir "massacrado pela família". Ao voltar para assumir os negócios do restaurante, sabe da importância da tradição, mas também não ignora as mudanças para continuar com as coisas funcionando. E recorreu ao velho subterfúgio de associar peças teatrais à programação de jantar fora, desta vez com o intuito de atrair pessoas de fora, os turistas. Afonso disse,

\footnotetext{
Por exemplo, quando tem peça boa, nós nos beneficiamos. Quando estava o Fantasma da Ópera, o pessoal da agência liga uns vinte dias antes e monta um receptivo. Eu atendo sem problemas, a coisa é que o Nelson de Abreu Pinto, o da capital gastronômica, montou isso para beneficiar o restaurante dele, o La Tavola, mas ele não consegue atender todo mundo, o restaurante dele tem mais de 1000 lugares, mas mesmo assim ele ainda fica disputando nossas famílias [...] Mas, no fim ele acabou fazendo uma coisa boa e fomentou o movimento para todos.
}

219 Giddens (1996) disse que "a tradição é um meio de identidade. Seja pessoal ou coletiva, a identidade pressupõe significado; mas também pressupõe o processo constante de recapitulação e reinterpretação observado anteriormente. A identidade é a criação da constância através do tempo, a verdadeira união do passado com um futuro antecipado", p. 100. Nesse sentido, parece que a memória é o amalgama dessa relação, revisitada como tradição entre os entrevistados. O próprio autor, em outro trecho compara a tradição à memória coletiva de Halbawchs, uma vez que reforça a ideia de que o passado não é engessado, mas continuamente construído (p.81). O que não se ajusta à trajetória da cozinha italiana é que para Giddens a tradição é atualizada no ritual, embora a cozinha italiana servida em restaurantes tenha autonomia da rotina, o que de certa forma fará com a refeição ocupe uma posição diferente da comida corriqueira. De qualquer modo, para ser uma tradição precisa persistir no tempo e ser reconhecida publicamente, outro aspecto que gera divergências, já que essa cozinha não é um consenso entre os estabelecimentos.

220 Nos Estados Unidos esse modismo ficou conhecido como comfort food, ou seja, comida que nos dá uma sensação agradável, de aconchego. 
A capital gastronômica dispersou os comensais, mas também trouxe outros que antes não tinham oportunidade de "desfrutar a cultura de São Paulo, ir ao teatro e comer fora", continuou ele. Trazer o cliente várias vezes ao mês para realizar uma refeição era comum nas cantinas e restaurantes tradicionais, inúmeras narrativas dos proprietários ilustraram essa prática que foi decaindo à medida que a cidade mudava e os obstáculos emergiam no cotidiano, impedindo manter o mesmo padrão.

Para alguns essa ideia de manter-se fiel às receitas, ao endereço e aos princípios da família foi o fator que desencadeou o declínio. No caso da Cantina Roperto, a tradição reforçou uma imagem de preservação, cuidado, respeito, pois "vender tradição não é ruim, as pessoas vem aqui para ver e comer isso". Vender tradição, para ele, é servir os mesmos pratos que há anos são parte do cardápio, bem como não fazer grandes mudanças no restaurante, embora algumas "tenham que ser feitas, como o caso do vinho". A ampliação do estabelecimento para atender aos novos comensais também aconteceu recentemente, mas emergiu um resultado curioso. A parte nova, contígua ao salão principal, é completamente diferente, pois utilizou materiais mais claros, pisos feitos de cerâmica, amplos espaços para espera, totalmente diferente do lado dito tradicional, ainda com paredes de madeira, quadros antigos, toalhas vermelhas sobre as mesas.

Paola, da Pizzaria Speranza, optou por um caminho diferente. Manteve o estabelecimento original na Rua 13 de Maio, fundado pelos seus avôs, e abriu uma filial totalmente diferente do restaurante original no bairro de Moema, embora mantivesse "os sabores tradicionais". Na verdade, ela atingiu um público que raramente iria até o Bixiga comer a pizza de seu restaurante, apesar de ter prestígio e reconhecimento. As dificuldades de se locomover na cidade e o medo da violência acabam concentrando as pessoas em volta de suas casas ou trabalho. A tradição para Paola é respeitada, uma vez que o cardápio, apesar de algumas mudanças, é basicamente o mesmo da pizzaria original, inclusive permanece a regra imposta pela avó de não dividir a pizza margherita com outros sabores:

\footnotetext{
Não adianta que nós não misturamos sabores com a pizza margherita, pizza é só margherita, mesmo que custe perder um cliente. O outro dia veio um cliente do Rio, ele não conhecia nossa pizzaria, mas tinha ouvido dizer que era a melhor de São Paulo, queria de todo jeito meia margherita e meia mussarela, os garçons não conseguiam resolver o problema e me chamaram, falei que não ia fazer. Ele ficou bravo, levantou e foi embora. Com toda a família e falando mal. Não adianta, eu vou respeitar a minha avó, e se foi assim que ela disse que tem de ser, assim vai continuar. Essa é a tradição e foi por isso que conseguimos chegar onde chegamos.
}

A tradição no sentido que se percebe entre os interlocutores é uma forma de moldar o passado para criar uma identidade, mas também prospectar uma imagem para o futuro ${ }^{221}$. De certa forma,

221 Para essa discussão, consultar Sutton (2001). 
garante segurança ao pressupor sua persistência. Para essas famílias, no entanto, a orientação para o passado e o reforço nessa ideia de tradição é um mecanismo acionado em função das incertezas cada vez mais fortes com relação ao porvir. Na verdade é um questionamento da própria identidade e da cozinha que praticam.

Estes interlocutores não sabem ao certo qual será o resultado dessas estratégias, mas sabem o que são pelo que suas famílias fizeram anteriormente e isso lhes dá um pouco de rumo para pensar a continuidade de seus estabelecimentos, bem como situar a comida ali servida quando comparada aos demais estabelecimentos. Ao se depararem com uma cozinha que se diz mais italiana do que aquela que é servida em seus restaurantes, a noção do que se é parece demolida.

Sem dúvida, a reação ao crescente descrédito aos restaurantes da velha guarda desdobrouse em distintas estratégias, mas a tradição foi de fato uma referência comum entre as pessoas ouvidas. A cidade, segundo eles, não reconhece esse pedaço de sua trajetória e os proprietários desses estabelecimentos fazem questão de lembrá-la, inclusive quando conseguem, recorrendo aos veículos de comunicação. O processo civilizador empreendido pelos italianos e sua comida servida em restaurantes não foi compreendido em sua verdadeira dimensão.

$\mathrm{Na}$ verdade, é provável que a cidade não ignore esse trajeto, apenas o tenha congelado para favorecer o surgimento de outras autoridades no assunto, transferindo o cuidado desse conhecimento das guardiãs (mulheres) para especialistas (chefs, críticos, gourmets e afins), como Giddens (1996) discutiu com relação à incorporação da autoridade. A sabedoria era própria das guardiãs, mas a competência é própria dos especialistas, deslocando a confiança de relações de proximidade familiar e de vizinhança, para uma confiança baseada na desincorporação e na competência técnica.

E essa é a ideia que parece estar presente nas falas de Fabrizio Fasano ao comparar seu trabalho com as cantinas. Quando retomou os negócios da família, ele e seu filho tiveram muitas dificuldades mas conseguiram se estabilizar pelo fato de terem entrado em uma área que na época pouco explorada, alta gastronomia italiana. Vistos como um restaurante caro e pouco acessível, o ponto escolhido para iniciar suas atividades foi o shopping Eldorado, acompanhando as mudanças daquele momento, fim dos anos 1980. A escolha se revelou um fracasso e o restaurante se mudou para uma rua próxima à Avenida Faria Lima que despontava promissora, Rua Amauri222. Era o início da migração de restaurantes dos Jardins para o Itaim Bibi e Vila Olímpia, bairros nobres da capital paulistas. As redondezas da Rua Amauri começaram a ganhar inúmeros estabelecimentos, e muitos de cozinha italiana renovada, como disse Fabrizio.

222 Hoje a Rua Amauri é um dos pontos com maior concentração de restaurantes refinados de São Paulo e da família Fasano abriga três estabelecimentos: Forneria, Enoteca Fasano e Parigi. 
Estar longe das regiões consideradas "de moda" é outra circunstância que interfere no andamento do trabalho, como lembrou Antonio Carlos, pois não consegue acompanhar essas contínuas novidades. Fiel à cozinha italiana que sempre serviu, não consegue atrair novos comensais na hora do almoço, em geral apressados, e tampouco à noite, segundo ele devido à localização muito próxima à Rua Rego Freitas, “antes eram os v...agora são as p...”, disse sem muitos rodeios, mas mesmo assim voltou para o centro, onde ele tem especial apego. Inaugurado em 1881 e passado às suas mãos em 1978, Antonio Carlos queria que o público correspondesse à altura da história de seu restaurante.

Esse apego a uma região que, outrora foi promissora, encontra também ressonância em um discurso comum entre os interlocutores que aponta para o declínio da qualidade do comer fora de casa, corroborados pela mídia. No fim dos anos 1980 e inicio dos anos 1990, são vários os comentários em torno de uma queda da qualidade oferecida em restaurantes, especialmente nas lanchonetes e pizzarias, embora fossem alternativas para driblar preços abusivos, pois ainda era uma época de instabilidade econômica e a palavra crise surgia repetidamente.

$\mathrm{O}$ surgimento de restaurantes em grande quantidade foi atrelado à nomeação da cidade como Capital Mundial da Gastronomia, segundo os entrevistados e que trouxe como consequência indesejável "gente aventureira". Esse último ponto é ilustrado pelo exemplo comentado por Paola, aborrecida com a concorrência. Ela contou sobre uma pizzaria recente, a Pizza Brás que foi concebida para parecer um estabelecimento tradicional, mas sua relação com a Itália termina por aí. O seu grande desapontamento foi que os proprietários da Pizza Brás copiaram um dos principais itens do cardápio da pizzaria Speranza, o tortello ou pão de linguiça, ao contratar um funcionário que vendeu a receita trazida e introduzida pela avó de Paola na pizzaria. "Agora vendido de qualquer jeito, olho aquilo e fico louca. Será que não pode ter respeito?", disse a interlocutora.

A indignação de Paola era traduzida de várias formas: pelo desrespeito à receita de sua avó, ao roubo do funcionário, à reprodução feita sem qualquer sentido familiar ou tradicional como em sua pizzaria. O pão de linguiça "tem história", não se trata apenas mais um item comercial do restaurante. No entanto, quem vai consumir não percebe essa diferença, a menos que tenha alguma intimidade com a trajetória da pizzaria de Paola.

Esse aspecto agrava ainda mais o peso de continuar as atividades do restaurante, uma vez que se está sujeito a vários tipos de "trapaceiros e desonestos" como argumentou Paola. $\mathrm{Na}$ verdade, os donos da Pizza Brás não estavam preocupados com a tradição, apenas queriam constituir um negócio e tomou tamanha proporção que hoje além de quatro filiais em São Paulo, já possui uma no Rio de Janeiro, ritmo que a Cantina Speranza não conseguiu imprimir para não "perder parte de sua história".

As narrativas que abordam esse tema nem sempre são livres de tensões. Ser fiel a um estilo que permitiu construir uma trajetória sólida ou se abrir aos novos diálogos que a capital 
gastronômica descortina são questões sempre presentes. Mas é fato que os entrevistados se sentem diminuídos em função da crescente valorização de uma cozinha italiana dita contemporânea e que tenta desesperadamente se firmar como universal. O que parece estar em jogo é a supressão de uma pluralidade cultural, várias expressões de cozinha italiana e de identidades, apesar da tão propalada retórica cosmopolita que se assenta na diversidade.

Esse aspecto abre uma nova frente para refletir sobre o processo que outorgou o título à cidade. Para alguns entrevistados significou a estagnação, para outros a necessidade de pensar transformações e deixar o caminho aberto para as novas gerações. Com medo de perder a tradição que lhes outorga identidade, permanecem muitos vezes alheios à transformação, o que permitiu que outros estabelecimentos ocupassem a cena da cozinha italiana na cidade.

Em uma enquete realizada pelo Guia 4 Rodas de 1990 sobre os pratos preferidos pelos comensais quando comem fora, com entrevistados por todo o Brasil, os resultados obtidos foram comentados pelo jornal O Estado de São Paulo ${ }^{223}$, e foi considerado "surpreendente": 3 pratos de massas (espaguete à bolonhesa, ravióli ao sugo, espaguete alho e óleo), 2 pizzas (mussarela e calabresa) e 1 filé à parmegiana entre o estrogonofe, frango assado, supremo de frango e filé com fritas. A conclusão do artigo é que "O paladar [...] pende para as comidinhas menos ousadas e com forte sotaque italiano". Se a cozinha italiana enfrenta dificuldades em determinar o que a caracteriza melhor, a nível popular parece que a solução está dada.

Em parte, esse resultado não é uma mera coincidência, pois é também quando a cozinha italiana ganha o mundo, aproveitando-se não só das sólidas bases já fincadas por meio das comunidades italianas, como também pela facilidade com que sua comida pode ser reproduzida. De uma cozinha considerada monótona e rústica, inclusive considerada dessa forma na própria Itália, passou a ser uma culinária reverenciada e renovou sua imagem atraindo para si as atenções de vários lados.

Paralelamente, a intensificação do fluxo de pessoas entre países, notícias e informações tornou essa cozinha popular fora de seu país de origem, bem como a transformou em produto turístico dos novos cosmopolitas beneficiados pela globalização. A cozinha italiana já circulava fora do território, mas agora é a cozinha que renasceu das intempéries da $2^{\underline{a}}$ Guerra e leva, para suas paisagens, turistas interessados em conhecer as delícias do País in loco.

Nesse ir e vir, muitos descendentes de italianos decidiram passar um tempo fora do Brasil e pelo fato de conseguir cidadania italiana a escolha acabava recaindo na Itália. Muitos filhos de proprietários de restaurantes foram fazer cursos e morar um tempo no país de seus pais e avôs, trazendo também as novidades conhecidas por lá, inclusive na comida que se diferenciava profundamente do que era feito em São Paulo, segundo os próprios interlocutores frisaram.

223 "Os eleitos pelos brasileiros na boca do forno", 17/11/1989, sem autoria. 
Um caso interessante é o de Sérgio Arno, dono do La Vecchia Cucina que apesar do que o nome sugere (a velha cozinha), introduziu "uma cozinha italiana moderna, mais leve". Neto de italianos e de uma família prestigiosa teve oportunidade de estudar na Itália. Lá conheceu a cozinha regional e percebeu como a cozinha de sua cidade era diferente daquela que encontrou na Itália. Voltou decidido a abrir um restaurante de "alta gastronomia" italiana, cujo modelo era nitidamente de outra natureza que os restaurantes que até então existiam na cidade. J. Curnonski em seu artigo de 29/12/1989 afirmou que era "o melhor dos novos [...] com sua cozinha italiana - a favorita de São Paulo - modernizada e renovada por atraentes combinações", embora ganhasse do autor apenas o prêmio pimenta-verde, "pequenino, mas resolve", o restaurante condensa as novas linguagens que se somaram às receitas das cantinas ${ }^{224}$.

Foi o momento em que a cozinha italiana se descolou da imigração, embora descendente de italianos, o restaurante de Sérgio Arno foi seguido por outros que nem sempre apresentavam algum vínculo familiar com a Itália, como Mezzaluna, no bairro dos Jardins e pertencente a um grupo de investidores, o Oliver (pasta e pizza) em moldes semelhantes. A cozinha italiana que será entendida a partir desse momento como prestigiosa é produzida por um especialista, se italiano muito melhor. Não é mais preciso o conhecimento das mammas, pelo menos para os restaurantes.

Em um momento de grande efervescência, em que restaurantes abriam continuadamente, os anos 1990 estimularam o comer fora de casa, especialmente como lazer. Em outra reportagem ${ }^{225}$, é dito que

São Paulo é, sem dúvida, uma dos centros gastronômicos do mundo. Aqui há de tudo e com qualidade, de comida japonesa aos pratos caseiros do Nordeste e de Minas, que surpreendem o paladar dos turistas estrangeiros.

É uma diversidade que também circula de distintas formas, mas não ignorou o apelo dessa imagem na formulação de uma identidade que define a cidade como capital gastronômica e disso impõe distância de outras cidades. Ela é diferente, é única, pela convergência de fluxos imigratórios, pelo progresso, por ser cosmopolita. Além disso, pelo seu crescimento também favoreceu mudanças nas dinâmicas do comer, fazendo com que comer fora por necessidade ou lazer se torne uma prática corriqueira.

Com essa nova estrutura, as mulheres perderam espaço na cozinha, embora abrindo lugar para uma nova geração que busca na formação profissional uma legitimação de seu conhecimento e de suas práticas. Nesse caso, estão filhas ou netas de famílias italianas que buscam se consolidar no negócio familiar pela cozinha, mas não repetindo o trajeto de sua mãe ou avó.

\footnotetext{
224 Jornal O Estado de São Paulo.

225 "São Paulo, eterno festival gastronômico", Folha da Tarde, 03/08/1988, de autoria de Cristina Sant'Anna.
} 
Contudo, nem todos aceitam bem que um herdeiro ou herdeira se dedique ao negócio como cozinheiro, ou melhor, chef. Não ignoram o discurso que atribuiu a esse personagem um poder legitimador para a cozinha, mas não aceitam que seus filhos trabalhem em um ambiente que para eles é considerado de segunda classe. É uma evidente disputa de campos em que se tentam manter as diferenças ante um fluxo que tende a atenuá-las. Não precisaram de um cozinheiro reconhecido para chegar onde estão e lamentam que isso não seja reconhecido, mas ao mesmo tempo consideram importante continuar o restaurante e não desprezam essa estratégia quando um filho ou filha optam pela carreira, mas temem pelo que os filhos vão encontrar.

\section{Chefs: cozinha italiana, mudança e continuidade}

Os restaurantes que surgiram na cidade não ofereciam uma cozinha paulista ou uma cozinha de distintas localidades nacionais, como ocorreu na França no fim do XIX e ao longo do século seguinte. Talvez resida aqui o que diferencia as trajetórias das mammas e das méres, a valorização do trabalho das mulheres italianas não tenha acontecido porque não foram instrumentos de uma política voltada para a construção de identidade nacional, até mesmo porque eram imigrantes, pobres e pertenciam a uma camada da população sem qualquer prestígio. As mammas foram conquistando espaço e sua imagem foi associada às cantinas, restaurantes que atraíram muitos frequentadores ao longo dos anos 1960 e 1970. Era um período em que os imigrantes, de modo geral, já estavam mais consolidados à paisagem local e começava a se fortalecer uma retórica em torno de sua contribuição para o progresso da cidade.

A comida feita e servida pelas mammas nas primeiras cantinas era, na verdade, um meio de consolidar vínculos entre patrícios que provinham de distintas regiões da Itália e compartilhavam uma mesma experiência que desestruturava seu cotidiano. As méres, ao contrário das mammas, eram centrais na construção de uma identidade local e jogaram luz a uma cozinha que tampouco era organizada e nitidamente reconhecida, mas encontrou estofo à medida que o turismo se consolidava e as diferenças regionais se demarcavam para formular uma imagem de nação ${ }^{226}$. É verdade também que sua contribuição foi sendo apagada à medida que os homens entraram em cena, mas ao menos regionalmente as méres ainda são lembradas e reconhecidas, sobretudo nos anos 2000 quando se acirram os movimentos contra a globalização.

As mammas não tiveram o mesmo reconhecimento, embora a cozinha italiana gerada nos primeiros tempos continue presente. Contudo, com a reviravolta da capital gastronômica e

226 Para a relação entre espaço, ambiente e geografia, consultar DEFFONTAINES, Jean-Pierre. Le terroir, une notion polysémique. In: BÉRARD, Laurence; CEGARRA, Marie; DJAM (2005). Ver também Bell \& Valentine (1997). 
concomitantemente a globalização da cozinha italiana contemporânea, o cenário de restaurantes foi afetado profundamente.

No que concerne ao trabalho feminino, poucas são as mulheres chefs de cozinha. Contudo, sua atuação não desapareceu. A partir de um estudo conduzido pelo IPEA (Instituto de Pesquisa Econômica Aplicada), em setembro de 2007, foi possível observar que a força de trabalho feminina nas cozinhas representa $65 \%$ do total de empregos no setor ${ }^{227}$, contrariando o imaginário comum com relação a esse tipo de ocupação normalmente atribuído ao universo masculino.

Em geral, a retórica que justifica a ausência das mulheres da cozinha é que se trata de um trabalho considerado pesado, sujo, exaustivo e até, perigoso. Pelos dados apresentados tratase apenas de um discurso sem relação com a prática, são omitidas das retóricas oficiais e nas memórias porque seu trabalho carece de um reconhecimento equivalente ao masculino. $\mathrm{Na}$ verdade, o que está em jogo é o perigo de mutilar uma imagem construída em torno do trabalho masculino na cozinha profissional em que o principal instrumento é a criatividade. A tradição perde terreno diante das criações dos chefs, amparadas em uma memória efêmera que se baseia na preservação de seus pratos por meio de livros, fotos, programas de TV e instrumentos da Internet, como blogs e sítios ${ }^{228}$.

O perigo das mulheres na cozinha seria representado pela ausência de um componente criativo em seu trabalho, uma vez que suas tarefas são rotineiras e destinadas ao mesmo público, sua família. É um cozinhar inspirado na rotina, monotonia, ausência de técnicas e restrições orçamentárias. Portanto, elas não emergiram nas narrativas de maneira direta, apenas como colaboração tangencial de um caminho que se vê muito mais pomposo.

Os interlocutores, sobretudo os mais velhos, sentem que a tradição é ameaçada quando a cozinha perde seus alicerces e, em parte, isso aconteceria pelas mãos dos chefs que não respeitam a tradição, ao menos desde a perspectiva que eles imaginam. Em geral, continuam leais aos seus cozinheiros e cozinheiras, muitos trabalhando no estabelecimento há mais de quarenta anos. “Já conhecem tudo, sabem como fazer, ensinam os novos funcionários, treinam o pessoal, e não tem essa empáfia dos chefs", comentou Ana Paula Lenci, do restaurante Gigetto. Quando perguntada sobre a possibilidade de substituir o principal cozinheiro e sentir alguma alteração nos pratos, ela disse que essa preocupação já foi superada, pois vários funcionários estariam sendo treinados para essa função, assim como sua sogra o fez quando saiu das atividades do restaurante.

Essa mesma referência emergiu em outras falas, Antonio Carlos Marino vê o chef como "arrogante [...], já "que todo mundo sabe que para ser chef não basta fazer um curso, é preciso

$227 \mathrm{Na}$ área de atendimento, composta por garçons, barmen, copeiros e sommeliers, as mulheres ocupam $42 \%$ aproximadamente dos empregos.

228 Consultar Sutton (2001) sobre essa questão que perpassa fortemente a divisão de trabalho na cozinha que apesar dos esforços femininos, suas publicações dificilmente ultrapassavam os estereótipos a elas atribuídos. 
experiência e muita!", referindo-se em especial aos que saíram da universidade há pouco tempo. Quando os herdeiros decidem fazer um curso de chef criam mais confusão no empreendimento familiar, pois supostamente teriam o aval da experiência de seus pais, embora não contem com o reconhecimento dos funcionários, que em geral são imigrantes nordestinos e os avaliam com desconfiança. Por outro lado, quando o chef não é da família, criticam sua atitude com relação aos funcionários mais velhos, normalmente com pouca instrução e humildes, mas grande experiência na área, especialmente na reprodução de pratos que foram passados entre gerações. A família teria um papel importante, bem como a italianidade, para avalizar a cozinha de um chef herdeiro, mas não de um chef autônomo.

De qualquer maneira, se novos pratos e cozinhas chegam à mesa dos comensais, as mudanças nas cozinhas parecem mais lentas, especialmente entre os que estão encarregados de produzir a comida, pois o padrão de transmissão de conhecimentos permanece associado ao mundo doméstico, isto é, quem recebe as instruções o faz pela observação e posteriormente replicará o que aprendeu. $\mathrm{Na}$ verdade, o grande medo em relação aos chefs está relacionado à perda de elementos que caracterizam determinada visão de si mesmo. As hierarquias persistiram no contexto interno desses estabelecimentos, mas mudaram com relação ao meio externo, agora mais exigente, dificultando ocupar a posição de brilho de outrora e desconfortável pelo atual lugar.

Dessa forma, explica-se porque tanta preocupação nos restaurantes da velha guarda em manter receitas passadas de mães para filhas, de filhas a funcionários, de funcionários a netos. É uma visão idílica das relações familiares, da produção de comida e dos comensais. É como se a cantina e o restaurante refinado de outros tempos estivessem submersos em um ritmo fora da escala contemporânea, mas ainda referendando uma identidade que não encontra mais a força em suas bases até então conhecidas.

Imaginar uma comunidade, imaginar a família, imaginar a imigração como um fator determinante no sucesso da cidade são algumas das formas de organizar o material das lembranças para dar alguma coerência a esses fragmentos. A nostalgia de não ver certos clientes, não existir mais aquele ar de cumplicidade com os comensais, de certos pratos terem desaparecido são questões que permeiam as memórias e jogam dúvidas sobre o futuro.

A tradição, no entanto, se submete a outras manipulações. Se ela é um instrumento importante para os donos de restaurantes tradicionais, ela é revivida de outra forma pelos restaurantes de alta gastronomia e chefs de cozinha. É um fenômeno que diz respeito ao distanciamento entre a cultura, grupo e território, mas que tende a celebrar a cultura do outro pela sua cozinha e resgata um imaginário de que os novos restaurantes e seus chefs trariam os sabores da Itália contemporânea para a metrópole traduzindo o melhor das cozinhas regionais para as mesas dos comensais. 
Vale lembrar que a cozinha italiana que chegou a reboque da globalização veio também gerada de uma tradição local, no entanto, deslocada de sua origem e reproduzida pelos restaurantes na cidade de São Paulo. Sua legitimidade, no entanto, não é questionada pela capital gastronômica, é uma cozinha que traduz maior italianidade: primeiro por estar mais antenada às dinâmicas atuais de sua origem, sendo o espaço então uma forma de atribuir maior veracidade a essa cozinha que, em segundo lugar, conta em muitos casos, com um chef. Esse ponto é visivelmente desconfortável para os interlocutores que não aceitam essa diferenciação, entendem isso como uma maquiagem para enganar comensais desavisados. De qualquer maneira, há uma ambiguidade explicita que intercala processos históricos e fluxos contemporâneos que cria distintas temporalidades para a noção de tradição apropriada em cada caso. A cozinha italiana da velha guarda não condiz com a Itália de hoje.

A cozinha que veio com os imigrantes e criou seu vínculo com o local e produziu sua própria interlocução se vê diante de uma cozinha contemporânea feita na Itália, de cunho regional e tradicional que chega aos restaurantes pelas mãos de cozinheiros profissionais e não mais das mammas, embora elas estejam atuando fortemente na valorização da cozinha regional italiana ${ }^{229}$. No entanto, não se pode negar que em ambas as situações há o intuito de fazer com que essa comida seja consumida pelos comensais, o que se insinua nesse caso são distintas formas de tradição, amparadas inclusive sobre temporalidades variadas.

Essa observação reforça o que já argumentou Appadurai (1996), as localidades não são soberanas, pois são feitas distintas articulações em função das temporalidades que incorporam. $\mathrm{Na}$ verdade, o local não é algo em si, mas algo para construir sentidos para o eu ${ }^{230}$, mesmo porque os imigrantes ao chegarem não viam a cidade como um espaço seu e nesse processo lapidaram uma nova cozinha cuja referência permanece italiana e foi construída ao longo do tempo e da interação entre imigrantes italianos e cidade. Essa referência remete ao conceito de habitus, já que cozinha italiana é algo interpretado localmente como algo natural, quer seja pela quantidade de imigrantes que chegaram, quer seja pela proximidade que conquistou entre as camadas mais díspares ${ }^{231}$.

Nos anos de capital gastronômica, a cozinha italiana que chega aos novos restaurantes é fruto de uma relação local moldada em seu país de origem, como também foi quando os primeiros imigrantes chegaram. A diferença reside em sua auto-imagem, pretensamente distinta porque não veio pelas mãos de um grupo sem prestígio e introduzida pelas mulheres, mas inserida nos fluxos globais e pelas mãos de cozinheiros profissionais, muitos sem qualquer relação com a Itália.

229 Um trabalho muito interessante a esse respeito, embora não focado em restaurantes são as relações de gênero e comida que Counihan (2004) descreveu entre famílias florentinas e o impacto de novas formas de cozinhar e comer.

230 Consultar também Geertz (1997).

231 Consultar DeCerteau (1998) para esta discussão. 
E tampouco deixa de dialogar com a cozinha italiana localmente produzida desde os primeiros imigrantes. O resultado dessa relação dependerá das forças que estarão em ação nesse encontro, pois não é só uma prática que visa a ocupar um determinado espaço territorial ou simbólico, mas uma questão de como se distribui o poder entre as partes, inclusive para além dos limites da cidade como mostra a disseminação do conceito de capital gastronômica por outras cidades.

A capital gastronômica precisa se fortalecer e os chefs de cozinha são instrumentos para essa consolidação. Contudo, se a cidade começa a ganhar seus restaurantes de alta gastronomia e a profissão de cozinheiro profissional toma as colunas especializadas da mídia, esse padrão não se repete em todos os estabelecimentos.

Restaurantes de menor prestígio e em especial destinados ao público que precisa comer fora por necessidade ainda se valem da mão de obra feminina e de grupos desfavorecidos, como imigrantes nordestinos. Apesar de toda a retórica que envolve o trabalho feminino nas cozinhas, são elas que ocupam a maioria dos postos de trabalho nesse tipo de estabelecimentos. Restaurantes refinados são poucos e estabelecimentos para servir refeições rotineiras e próximas da casa não são necessariamente os espaços desejados pelos chefs para trabalhar.

Essa constatação sugere que o cozinhar é ainda uma tarefa predominantemente feminina, pois ainda permanecem hierarquias da esfera doméstica transpostas ao domínio público. A cozinha de todo dia, considerada uma tarefa quase obrigatoriamente feminina, estendeuse ao universo das relações de trabalho nas cozinhas. Restaurantes de caráter mais popular para atender a refeições cotidianas incorporam maior número de mulheres, ao contrário de restaurantes que servem refeições mais elaboradas, onde a maioria dos chefs é masculina, assim como os funcionários que ali trabalham. Uns servem comensais apressados e desejosos de uma comida similar ou próxima à elaborada em casa, outros procuram uma experiência diferente. Os restaurantes tradicionais de cozinha italiana ficaram perdidos no meio do caminho já que não atendem comensais em seu horário de almoço, tampouco servem refeições diferenciadas.

Esse aspecto ficou ainda mais evidente ao analisar a trajetória dos restaurantes italianos na cidade de São Paulo. A revelação de vestígios do universo doméstico na cozinha profissional reforçou o diálogo travado entre comida, espaço e hierarquias sociais e é considerado pelos interlocutores de restaurantes mais refinados como uma espécie de poluição. A cozinha profissional não pode estar associada à cozinha doméstica com risco de perder suas qualidades distintivas, em especial a criatividade.

Nessa interlocução entre cozinha e a produção da comida existe uma busca por uma identidade para o restaurante e que irá reverberar em sua italianidade. Se há uma nostalgia dos velhos tempos é preciso lidar com dinâmica que a cidade impõe, embora o custo de renovar seja extremamente penoso para os entrevistados. As receitas e conhecimento feminino ainda circulam pelo mundo desses estabelecimentos, mas é residual na medida em que já foi totalmente descolado das 
mulheres, o que sugere que essa tradição é bastante superficial, já que seu alcance não chega nem às primeiras gerações. Curiosamente, é no material mais recente que as memórias encontrarão apoio e o que no início gerou incertezas quanto aos caminhos percorridos pelos restaurantes e as famílias que os abriram.

Em parte é um processo de transição como sugere Connerton (1989) em que um o saber oral irá ser sobreposto pelo saber escrito, de incorporação de práticas para práticas inscritas. Isso não implica o desaparecimento do aprendizado pela observação e repetição de movimentos e técnicas corporais, especialmente na cozinha, mas terão de conviver com as determinações escritas e, paradoxalmente, dificultando as inovações tão preciosas para os chefs de cozinha.

Mulheres na cozinha estão na base da hierarquia, homens na cozinha de origem humilde e de pouca instrução ficariam um pouco acima pela questão de gênero, e no topo os cozinheiros profissionais. As mulheres apesar de centrais para a constituição de um comer público, nunca chegaram a ter brilho próprio, nem mesmo trabalhando ao lado do marido ${ }^{232}$. A maioria assumiu uma posição colateral e seu trabalho considerado apenas como colaboração.

A saída de cena dessas mulheres foi lenta e as cantinas, bem como os restaurantes, se deparam com novos ritmos que se acentuam com força ainda maior no cenário dos anos 1990, sobrevivendo em alguns poucos casos como na cantina Jardin di Napoli, onde Dona Leonor, mãe de Adolfo Scardavelli, cozinha há quase cinquenta anos. O curioso é que pouca gente sabe de sua existência, pois normalmente a invenção dos pratos, como o famoso polpetone, é atribuída ao dono do estabelecimento, Antonio Buonerba. Ela seria apenas a executora dos pratos, embora detenha o conhecimento completo das distintas etapas de produção de cada prato, ao contrário de seus funcionários. Esse procedimento, segundo Adolfo, seria para evitar que o segredo do polpetone fosse descoberto e copiado por outros restaurantes. Se ela não é uma chef reconhecida, os seus encargos sugerem que há um descolamento entre seu reconhecimento e sua responsabilidade ${ }^{233}$.

Nesse caso em especial, há uma ambiguidade entre saber doméstico e saber profissional, pois de certa forma ela detém o conhecimento do processo tal é feito na cozinha de casa, mas não abre sua totalidade aos funcionários, tal como é feito em cozinhas profissionais. Difere ainda no fato de que esse saber está apenas concentrado em sua cabeça e na de Antonio Buonerba, nada escrito, apenas ensinado na prática. São resquícios do modelo anterior e que agora precisam de uma transição para se adequar aos tempos de Capital Mundial da Gastronomia.

232 A única exceção foi a Cantina Balila, inaugurada e chefiada por mulheres, passou por várias dificuldades e acabou fechando suas portas por volta de 2004, não tendo conseguido entrar em contato com a família.

233 A família Buonerba também lançou um livro contando a história da família e da cantina, "Alla napoletana", levantando um aspecto interessante que poderá ser analisado em outro momento, a forma como essas famílias buscaram deixar registrado em livros sua história em particular. Essa trajetória foi seguida também por Mario Tatini, Giovanni Bruno e Ângelo Luisi, embora este último não tenha um livro só seu, mas tenha um vasto capítulo em Medina (1983). 
Ela é orgulho de seu filho, "trabalhadora, como toda mulher italiana", mas desaparece da retórica oficial. A confiança depositada na família de Adolfo pela família de Antonio é evidente e sem ferir as expectativas dos proprietários, a receita continua guardada no mais estrito segredo.

No entanto, recentemente Dona Leonor manifestou desejo de se aposentar e treinou uma pessoa para assumir seu posto que, além deles, é a única que sabe o processo completo do preparo do polpetone. A decisão recaiu por ser uma

Pessoa de confiança [...] Muita gente já quis tirar minha mãe daqui e ela nunca saiu, sempre aqui, mantendo as coisas funcionando [...] Podia ter ganho dinheiro dando a receita do polpetone, mas ela nunca fez isso.

Essa confiança é inspirada com base em relações que parecem seguir um padrão familiar e, embora Adolfo não tenha mencionado, é possível que tenha alguma participação no restaurante, dificultando oportunidades de abrir um restaurante ou trabalhar em outro lugar. Está satisfeito em sua posição e acredita que dessa forma as coisas funcionam bem, sentindo-se um "verdadeiro italiano".

A continuidade das receitas e das atividades na cozinha não se concentra mais em torno das mulheres nem nos descendentes, mas em funcionários. No entanto, as famílias, tal como os Buonerba, se sentem donos das receitas e não as divulgam, caso o façam, paira a dúvida quanto à fidelidade, pois o segredo também é uma peça importante desse quebra-cabeça.

Sair da cozinha, segundo Adolfo, foi para sua mãe uma decisão ocasionada pelo esgotamento físico, pois os interlocutores compartilham a ideia de que esse trabalho é "pesado" para o corpo feminino, embora tenha ficado no mesmo posto há quase cinquenta anos. Trabalho físico estafante não seria condizente com as mulheres e menos com a prosperidade econômica, uma vez que tarefas corporais que exigem grande esforço estão associadas a posições menos favorecidas. São para o grupo de pessoas que não tendo um preparo mais adequado, não resta outra saída a não ser usar o corpo para ganhar o sustento. Nesse caso, aos migrantes nordestinos coube dar continuidade ao trabalho iniciado pelas mulheres.

Afonso Roperto dá pistas dessa passagem quando comenta sobre o trabalho de sua avó, sempre presente na cozinha do restaurante, ao contrário de sua mãe que não participou dessa atividade, mas lembrava que sua avó era muito ativa. "Naquela época, as mulheres cuidavam da cozinha e os maridos da administração (compras, atendimento e financeiro)", processo que não foi exclusivo em seu estabelecimento e que nas gerações seguintes se transformou em uma ajuda eventual.

Por outro lado, não se pode esquecer que cozinhar ficou associado a uma atividade de menor prestígio, o que não deixa de ser verdade, especialmente por estar concentrada na casa. E 
muitas mulheres de camadas favorecidas para se afastar dessa condição negativa, simplesmente ignoraram a tarefa do cozinhar, repassando-a a terceiros, especialmente as empregadas domésticas.

Esse processo levanta outro ponto importante do trabalho em restaurantes, se para as mulheres a prosperidade econômica representava um retorno ao lar, para os migrantes nordestinos representava um meio de ascensão social. Muitos funcionários que começaram em posições modestas como lavadores de pratos ou auxiliares de limpeza tiveram oportunidades de ascensão social e econômica, ora ocupando funções de mais prestígio como gerentes, ora como encarregados da cozinha ou mesmo tendo a oportunidade de abrir seu próprio estabelecimento.

É nesta transição que a cantina conhece seu auge, mas é também quando as sementes de seu declínio são plantadas. Caindo no gosto das camadas médias urbanas nos idos dos anos 1970 rapidamente as velhas cantinas familiares foram exaustivamente copiadas e muitas ficaram com péssima fama. Curiosamente, mesmo sem mulheres na cozinha, o peso negativo recaiu sobre elas, uma vez que foi de seu conhecimento que surgiram os pratos. Se a omissão de sua contribuição é clara, o fato das cantinas não terem qualidade é porque a comida foi inspirada em casa e nas mulheres, como os proprietários de restaurantes refinados gostavam de frisar.

Fabrizio Fasano, hoje proprietário de vários restaurantes de cozinha italiana dita contemporânea, além de um hotel e de um bufê, este sob comando de sua filha, avalia a contribuição das mulheres como algo inferior. Ao comentar com ele sobre um restaurante na região da Toscana e cuja comida era espetacular toda feita por mulheres, ele comentou:

\footnotetext{
Não é uma cozinha de chef, a cozinha de mamma é isso aí que a gente vê nas cantinas, macarrão boiando em molho de tomate e queijo, não é isso que você vê aqui, a gente trouxe até um chef de fora para o Fasano, isso que elas fazem não é cozinha italiana.
}

Fabrizio repetiu em diversos momentos comentários a esse respeito, evidenciando um preconceito que circula no senso comum da cidade a respeito das cantinas, elas decaíram e sua comida com "cara de casa e sotaque do sul" deixaram uma mancha quase indelével nos estabelecimentos. As mulheres não são lembradas pela sua contribuição positiva, mas por meio de uma percepção negativa em que o doméstico polui o público, especialmente quando esse espaço é a cozinha, por si só ambígua.

Essa referência surge também nas falas de Aurélio Guzzoni, que conta com orgulho o fato de seu pai ter trazido dois chefs italianos para o restaurante do hotel. Fabrizio Tatini tampouco abriu a cozinha para sua filha e esposa, pois apesar do conhecimento que tinha, não era apropriado para uma cozinha profissional, de restaurante. 
Por outro lado, nas velhas cantinas, o ir e vir das mulheres passará por algumas transformações. No caso de Ângelo Luisi o seu auge foi ao longo dos anos 1970 e foi quando sua esposa, Angela, ficou menos atribulada com os afazeres da cozinha do restaurante, já que funcionários foram contratados. Quando os anos sombrios se abateram sobre eles, especialmente nos anos 1980, Angela voltou para a cozinha para ajudar seu marido que passava por dificuldades.

Em outros casos, como a Cantina Speranza, as netas de Speranza Tarallo assumiram o comando das atividades ao lado dos irmãos, mas em posições muito distintas da avó. Foi nesse período que novos rumos foram necessários para sobreviver, e a cantina além dos pratos do sul da Itália, intensificou a venda de pizzas que nesse momento preparava seu boom na cidade.

Tanto Paola, como sua irmã, procuraram uma formação para poder ocupar lugares de comando nos negócios. Paola fez administração e especialização em marketing e sua irmã fez faculdade de gastronomia, são "novos tempos", inclusive para:

Melhorar o desenvolvimento de uma linha de produtos prontos, como massas e molhos, que serão vendidos nas casas e, posteriormente, distribuídos em supermercados ${ }^{234}$.

As irmãs foram legitimadas nessa posição porque tiveram uma educação, buscando fora da prática cotidiana, um meio de conquistar um espaço diferente da avó que trabalhou durante anos na cozinha.

Nota-se que a mulher participa de maneira menos ou mais ativa em função do tipo de empreendimento familiar e as relações que estabelecem com suas origens, trazidas à tona em função da trajetória familiar e do envolvimento com o trabalho. A avó de Paola foi uma presença marcante, mas permaneceu à frente das atividades até que se sentiu suficientemente segura para deixar a cargo do filho e os negócios engataram um caminho positivo. Família, negócios e novas orientações profissionais multiplicam as decisões que envolvem assumir ou não as atividades da cantina.

A posição das mulheres nestes novos tempos busca ser reconhecida como legítima, mas nem sempre sua entrada no restaurante da família é tranquila. Esse ponto é muito bem ilustrado por um caso ocorrido na família Tatini. Alguns anos mais tarde, Mario abriu um restaurante junto de um de seus irmãos no bairro do Itaim e ambos pretendiam que ficassem com os filhos. Uma das sobrinhas de Mario foi preterida pela família para assumir um cargo importante, que ficou com seu primo, e arrasada pela escolha, saiu do restaurante. Em seguida abriu outro estabelecimento usando o sobrenome da família, Tatini, em Alphaville o que desencadeou uma longa batalha em torno da questão, causando um desgaste profundo na família ${ }^{235}$.

234 A interlocutora me deu de presente alguns vidros dos molhos, dispostos em lindas embalagens que sugeriam algo preparado de modo doméstico, com amor e que trazia indicações da "tradição familiar" em servir boa comida.

235 Problemas com o uso do nome também foram relatados por Giovanni Bruno que foi impedido de colocar seu próprio nome em um novo restaurante, após a venda de seu estabelecimento para um grupo de sócios que disseram ter comprado o direito de continuar utilizando Giovanni Bruno como denominação do restaurante. 
Nesse caso, além das questões de gênero entra também os enfrentamentos entre gerações que nem sempre são resolvidos de maneira amigável, especialmente quando a sociedade envolve a parentela extensa. As novas gerações de mulheres não querem ficar à parte do empreendimento familiar, mas nem sempre encontram um lugar para si. São resquícios ainda de uma atitude que mistura percepções de classe e gênero.

Essa atitude combativa seria inesperada se não fossem novas atitudes em torno da colocação profissional, embora seja evidente a persistência de desníveis com relação à valorização das capacidades de homens e mulheres no tocante à condução do restaurante. Agrava-se a situação se pensada à luz das oportunidades de estudo que as mulheres dispõem, equiparando-as aos homens. Se os pais incentivam seus filhos e filhas a cursarem uma faculdade e assumirem os negócios de modo "mais profissional", existe uma dificuldade em introduzir novos conhecimentos aos funcionários antigos e familiares tanto para os homens, mas em especial para as mulheres.

Embates e confronto de opiniões são comuns, bem como dificuldades em lidar com funcionários antigos, principalmente os que estão na cozinha cuja experiência foi proveniente da prática, muitas vezes sem qualquer outra instrução a não ser a observação e o fazer. Sabotagens, ironias, desprezo são algumas das atitudes que os herdeiros precisam enfrentar, especialmente quando se trata do cozinhar. A formação de chef é percebida de modo ambivalente e pior ainda quando se é mulher.

Para os pais é uma tentativa de dialogar com os novos fluxos de informação, para os filhos é encontrar o preparo necessário para assumir o restaurante e para os funcionários, um momento de insegurança. Trocar o bastão de comando por si só já não é um processo isento de dificuldades, especialmente quando o homem conquistou certa posição econômica e social que os filhos se sentem obrigados a manter.

A formação profissional, como se vê, não garante muita coisa, pois a ausência de intimidade com o restaurante e os obstáculos que impedem mudanças drásticas, especialmente na comida, são fontes de potenciais conflitos. As netas ou filhas não querem seguir os passos das mães e avós, embora reconhecidas pelo seu envolvimento na cozinha que é, em geral, derivado da esfera doméstica. Os filhos ou netos se sentem na obrigação de manter as condições conquistadas e o estudo, apesar de importante entre as famílias, não facilita de imediato essa transição, uma vez que tocar em receitas do restaurante seria o mesmo que tocar no íntimo de sua italianidade, ao menos aquela percebida pelos proprietários.

Estudar é um ganho de capital simbólico, mas nem sempre reconhecido internamente no restaurante, embora tenha uma percepção positiva para a família. Contudo, quando se trata de formação profissional na cozinha, os novos chefs se são da família tem um espaço limitado para seu trabalho, assim como aqueles sem vínculos representam uma desordem eminente na cozinha. 
Esse último ponto é bastante interessante, pois se os netos ou filhos adquirem conhecimentos para atuar na cozinha por meio de cursos em escolas especializadas, seus pais os vêem mais aptos que outros profissionais não só pela aquisição de um título, mas também pela proximidade com as atividades do restaurante, "já sabem um pouco como funciona a coisa", comentou João Donato, não estariam tão crus como outros recém-formados, que "não sabem nada e dizem que são chefs", segundo Antonio Carlos Marino que ainda disse:

\begin{abstract}
As faculdades de gastronomia só tratam da comida, o cozinheiro aqui tem 30 anos de casa, tem funcionário analfabeto e foi sendo criado na prática e cresceu. Ele não é chef, pois no fundo esse é o administrador, o meu é cozinheiro mesmo. É outro mundo, o pessoal formado não dá conta dessa 'peãozada'. A grande maioria dos restaurantes não os coloca na cozinha [...] não aguentam um domingo na cozinha, então vão para a área administrativa, pode dar uma consultoria, ajuda no pré-preparo [...] É uma moda.
\end{abstract}

Sem dúvida é uma perspectiva produzida desde seu lugar de observação e isso ainda adiciona mais combustível à fogueira do desencanto com relação à capital gastronômica. Segundo Aurélio Guzzoni, “o mercado de São Paulo está saturado”, muitos restaurantes abrem e fecham, confirmando a observação de Antonio Carlos em torno do modismo. João Donato também concordou com relação a essa proliferação de chefs, "acho que a coisa mudou para pior" e desconfia não só desses profissionais, mas também com os produtos que hoje são utilizados nas cozinhas de restaurantes,

Tudo industrializado, não tem mais nada artesanal [...] eu ainda sou adepto de manter algumas coisas [...], mas tem que acompanhar as mudanças, se não você fica para trás.

$\mathrm{Na}$ verdade, sua desconfiança vai além, pois ele não acredita que um chef de verdade utilize produtos industrializados em larga escala em seu restaurante, pois isso não se harmoniza com a ideia que sua profissão proporciona. Na verdade, é uma contradição, pois o cozinheiro deveria inspirar confiança, e resta a dúvida que preceitos serão seguidos. Uma perspectiva mais atenuada é oferecida por Afonso Roperto, pois vê os chefs como formadores de opinião,

O chef de cozinha tem a mesma influência do costureiro, nem sempre o que ele cria está na boca do povo [...] Meu tio é cozinheiro, você cozinha, a prima cozinha, quando coloca um chef na cozinha, o tempo todo tem que estar ajustando receitas. [...] O cardápio tem um esqueleto que não se mexe de jeito nenhum e como fica o chef? [...] A tradição é importante para o italiano [...] e meu orgulho é que minha família tenha contribuído.

Afonso resume os sentimentos dos entrevistados. Eles sentem que algo está ficando para trás quando, pois se o chef se vale da tradição, ela não é do mesmo naipe que a temporalidade 
dos restaurantes de velha guarda supostamente lhes conferem. Além disso, o fato de ter um relacionamento estreito com a Itália, seja descendente ou nascido lá, atribui para estes interlocutores um valor que um cozinheiro profissional dificilmente conseguirá incorporar, uma vez que está distanciado da "cultura italiana", como frisou Afonso, embora possa "absorver algumas coisas pelo aprendizado". Para si e para fora, esses restaurantes tentam assentar sua identidade, sem se perder na capital gastronômica e encontrando nos vínculos mais próximos uma forma de se legitimar.

Relações entre gerações, entre gêneros, fortalecimento do capital simbólico, estratégias para sair do antigo para atingir o tradicional se imbricam para dar sentido à continuidade de um trabalho que muito está relacionado à própria imagem que esses personagens criaram para si e, em alguma medida, tentam recuperar. Para eles, falta "a alma do italiano" nesses novos restaurantes, vistos mais como empreendimentos comerciais do que empresas familiares ou uma expressão dessa dita cultura italiana. De repente, um novo aspecto emerge: a cozinha por si não corresponde à cultura, apesar do que se é levado a pensar na capital gastronômica.

O chef, para a velha guarda, não passa de modismo, para os novos restaurantes representa o acesso à verdadeira cozinha italiana. Nesse sentido, o grande contraponto surgiu em restaurantes médios e de alta gastronomia que servem especialidades regionais, em especial uma concebida como cozinha mediterrânea.

Esse conceito teve grande repercussão a partir dos anos 1990 e foi um motor de impulso da cozinha italiana pelo mundo em função de sua associação aos benefícios trazidos à saúde ${ }^{236}$, pois é uma dieta baseada em receitas bastante simples utilizando muitas verduras, legumes, peixes e azeite de oliva. A divulgação foi maciça e a Itália transformou-se nos anos 1990 o reduto preferido de férias, especialmente para camadas médias urbanas que buscavam os encantos do País não só nas grandes cidades, mas também pelo interior e nas pequenas cidades da costa, criando uma fantasia em torno do rural ${ }^{237}$. Uma fantasia que tentava dar aos moradores dos grandes centros urbanos um caminho para resgatar sabores perdidos pela comida rápida, pelos produtos industrializados e pela dissolução das refeições feitas em família e em casa.

A cozinha italiana com sotaque mediterrâneo, inclusive, foi o slogan adotado por uma grande rede de comida rápida, Ráscal, embora não necessariamente um fast-food, o princípio que utiliza se apóia nas dinâmicas desses restaurantes: produção padronizada, serviço homogêneo, preços acessíveis. Com uma vasta oferta de produtos que remetem à cozinha italiana, se bem

236 Considerada por estudos conduzidos nos Estados Unidos na década de 1990 como a dieta ideal baseada em peixes, verduras, legumes e azeite de oliva, além do vinho tinto. Levenstein (2003 a ) diz, em tom jocoso, que é a vingança da imigração italiana que durante anos foi obrigada a mudar seus costumes para atender políticas de alimentação locais, como a introdução de produtos lácteos e carne, pois sua alimentação feita à base de verduras, legumes, azeite, algum queijo e embutidos era considerada "pobre".

237 Para uma análise mais ampla dessa revitalização do mundo rural, consultar Leitch (2000), citada em Sutton (2001) e Menasche (2007). 
que já bastante globalizados como presunto cru, queijo parmesão, tomate seco, azeite de oliva, massas, molho de tomate, o restaurante oferece distintos bufês onde é possível consumir saladas, antepastos, pães, massas e carnes, degustados sem limite mediante o pagamento de um preço fixo.

Para quem não quiser seguir esse modelo, há também a opção de fazer o pedido no cardápio, inclusive pizzas na hora do almoço, um costume raríssimo na cidade de São Paulo, onde o consumo de pizzas é mais comum à noite ao contrário da própria Itália, Estados Unidos e Argentina.

Vale lembrar, inclusive, que cozinha mediterrânea é uma classificação bastante genérica de um conjunto de culinárias encontradas em vários países e regiões ${ }^{238}$. Na verdade, o exemplo do restaurante Ráscal nos revela uma adaptação de elementos tradicionais a diálogos recentes entre cozinha saudável, traduzida na dieta mediterrânea, e a necessidade de realizar refeições rápidas dos comensais. Além disso, não demanda a presença de um chef no sentido como é comum percebê-lo, já que a produção dos pratos servidos é feito em larga escala, de modo padronizado, para ser consumida rapidamente, tanto na hora do almoço como no jantar. Não se faz necessária uma assinatura de chef como se espera de um restaurante cujo acesso é mais restrito, como os bistrôs ou aqueles que afirmam fazer alta gastronomia italiana.

Quando o negócio adquire um caráter profissional, mesmo quando familiar como é o caso do Ráscal, é evidente que novas reflexões se fazem necessárias para entender as respostas dadas diante das condições que se impuseram aos interlocutores e seus estabelecimentos. O exemplo do Ráscal é bastante elucidativo, pois incorpora administração dita profissional de restaurantes sem perder sua identidade familiar, a comida italiana servida dialoga então com distintos níveis: geográficos (mediterrânea, do sul, do norte), tempos (contemporânea, tradicional) e tipos de serviços (bufê, à la carte), além de servir pizza a qualquer hora. Nesse restaurante pode ser encontrada uma cozinha "mediterrânea e saudável", segundo as próprias palavras de Roberto Bielawski, proprietário da rede de restaurantes em uma entrevista à revista da companhia aérea Gol de maio de 2008.

As massas não são nem do sul, nem do norte, mas adaptações de várias regiões, misturando o uso de ingredientes locais (palmito pupunha, carne seca, abóbora) a ingredientes considerados de melhor qualidade como presunto cru, alcachofras em conserva, cogumelos etc. que convivem ao lado de bruschettas, focaccias, pizzas, pães recheados, queijos parmesão, carpaccio, cuscuz, queijos dispostos nas mesas de bufê. As sobremesas são separadas, mas não exclusivamente italianas como o tiramisú (sobremesa com queijo, café e chocolate em pó), mas também torta de chocolate com molho de morangos, torta de queijo com calda de framboesas (cheesecake), sopa de morangos com sorvete, torta de maça ou torta de goiabada.

238 Entre eles: Espanha, Gibraltar, França, Mônaco, Malta, Eslovênia, Croácia, Bósnia e Herzegovina, Montenegro, Albânia, Grécia, Turquia, Síria, Líbano, Israel, Palestina, Egito, Líbia, Tunísia, Argélia e Marrocos. 
Nessa versão contemporânea da cozinha italiana estão embutidos vários elementos que relembram a cozinha tradicional e a cozinha sofisticada, mas adaptadas ao contexto homogeneização e acessibilidade, sobretudo porque apesar de suas características é um restaurante que possui várias filiais e se pode comer rapidamente. Além disso, flexibiliza amplamente a escolha individual do comensal, um aspecto que nem sempre está contemplado nas fartas porções das cantinas.

Coincide a difusão dessas novas linguagens da cozinha italiana pelo mundo com um movimento de resgate de cozinha regional. Não que houvesse desaparecido do conjunto de pratos e técnicas da culinária italiana, mas ganha um reforço em função da própria globalização que tende a homogeneizar alguns sabores. Nesse sentido, são produzidas novas localidades que estabelecem um diálogo com o território, grupo e produtos, mas que também não deixa de servir à circulação de informações pelo mundo, ressaltando inclusive, o imaginário romântico rural.

Curiosamente, apesar da retórica do senso comum não mencionar, já que se foca na questão de perda de raízes, esse resgate ressuscita o papel feminino, pois a cozinha regional é fundada em origens domésticas, cujos pratos e receitas iniciaram seus passos na cozinha de casa e muito mais tarde ganharam os cardápios de restaurantes. Se a mensagem que se deseja passar com essa retomada das cozinhas regionais é olhar para o passado, é preciso pensá-lo não só em termos de espaço, mas também de quem esteve participando no processo. E novamente as mulheres são escassamente referidas, pois a atenção está fixa nos pequenos produtores rurais, afetados pelos manejos globais.

Ante tudo isso, as cozinhas regionais italianas emergem como os novos fundamentos da cozinha nacional e sua expressividade é percebida como parte da riqueza cultural do País. É a volta dos regionalismos, porém pautados por outro ritmo. Se no início da imigração demarcavam pertencimentos e disputas em grupos que mostravam as diferenças pela comida pública, a ruptura foi sendo dissolvida à medida que os primeiros imigrantes se integravam à paisagem local. O regionalismo irá retomar força quando entram os novos imigrantes do pósguerra e demarcam distinções entre aqueles que chegaram aqui no começo do século e aqueles recentemente.

O novo regionalismo que se fortalece em tempos globais vem para falar sobre modernidade, a Itália que progrediu, civilizou-se. Não mais aquela Itália de imigrantes que apreciavam massas pesadas com molho de tomate e queijo derretido, dos pratos do sul e do norte, mas da Itália que irá civilizar os paladares cosmopolitas, atentos às particularidades que caracterizam as distintas cozinhas encontradas na península.

Nas cantinas perduram as reminiscências femininas em torno dos pratos, do apelo familiar, mas também não estão cotidianamente presentes na produção, embora os novos diálogos com a 
Itália contemporânea e os seus regionalismos culinários o embate entre tradicional e autêntico ganhe novo fôlego. Na verdade, essa distinção se expressa menos na comida e mais no plano das ideias, fazendo com que antigos e novos restaurantes se entreolham com mútua desconfiança.

No entanto, se a nível de retórica discorrer sobre as diferenças regionais atribui um poder civilizador ao restaurante e aos seus comensais, o que se vê de modo mais acentuado é uma mistura de pratos provenientes de distintas regiões, bem como de cozinha italiana, cozinha mediterrânea com ingredientes locais. Não se distingue ao certo o que caracteriza cada categoria, é comum que em muitos restaurantes sejam servidos pratos de regiões completamente opostas, como risotos e massas feitas com verduras.

O que difere bastante é o aumento da oferta de restaurantes italianos, pizzarias e entrega de pizzas (deliveries). Pequenos, médios, familiares, simples, sofisticados, comida italiana está por toda parte. Nesse sentido, se tradição e autêntico se mesclam, se fundem e são apropriados por distintas retóricas, compartilham uma chave em comum, isto é, a repetição de práticas na cozinha, bem como um gosto que aprecia cozinha italiana, ambos disciplinados no corpo. Contudo, cada qual busca no repertório cultural formas de legitimação, o tradicional se vale das origens imigratórias, ao menos entre os estabelecimentos analisados; os novos restaurantes italianos buscam na força do território, Itália, e no conhecimento dos chefs o selo de autenticidade.

São habitus que parecem agir sob distintas orientações. No caso das cantinas e restaurantes mais refinados inaugurados nos anos 1950, a tradição está impressa na vinda da família, no trabalho, nas origens e na passagem do conhecimento entre gerações. Nos restaurantes contemporâneos é o saudável, a evolução da cozinha italiana feita no próprio país considerada mais verdadeira que aquela encontra na cidade de São Paulo, mais italiana e mais autêntica que sua congênere local. De um lado, é o conhecimento adquirido pelos anos de experiência; de outro, é o conhecimento adquirido com estudo e pela suposta italianidade mais acentuada na cozinha contemporânea e pela metade desse percurso, os restaurantes refinados dos anos 1960 e 1970 hoje sem atrativos.

O tempo ainda joga outros papéis, pista sugerida por Appadurai (1996). De um lado, entre os restaurantes tradicionais inovar significa justamente comprometer essa tradição, mas há também uma preocupação em "não ficar para trás" o que incita à mudança, porém limitada pela força do habitus que exige uma disciplina para sua prática e amenizando eventuais improvisos e inventividade. Acompanhar o tempo da tradição parece ter um custo que é justamente imposto pela velocidade dos consumidores cosmopolitas.

A novidade é um aspecto central nessa lógica e orienta as práticas de chefs, mas revela outra situação paradoxal. Se eles legitimam a cozinha italiana hoje praticada em restaurantes como é possível que sua inspiração venha justamente de cozinhas regionais italianas que tanto prezam suas raízes rurais, simples e, sobretudo, domésticas, deixando essa reflexão em aberto. 
Em geral, a justificativa de se inspirar em uma cozinha antiga é com o intuito de renová-la e para tanto dependerá da interpretação do chef, improviso que está autorizado a fazer graças ao conhecimento adquirido. O mesmo não parece acontecer com os pratos das cantinas.

Desse modo, a inércia existe e terá maior solidez em função da fidelidade a determinada posição. As cantinas não se fecharam às mudanças, mas falam de modo mais evidente de uma história na cidade, ao contrário da cozinha que se encontra hoje em restaurantes contemporâneos, embora não ignorem essa herança, desvalorizam a comida ali preparada e servida. É o convívio entre uma comida ainda com resíduos étnicos e uma comida cosmopolita. Uma está associada ao local a outra descolada de sua origem, mas legitimada pelos envolvidos em seu preparo. São diferentes temporalidades que dialogam com espaços também variáveis, e o tradicional e o autêntico falam sobre isso.

Curiosamente, o autêntico, segundo van den Berghe(1984), sempre esteve ligado ao consumo de comida por pessoas da comunidade e seus descendentes, o que parece ser reivindicado pelos interlocutores, pois durante muitos anos serviram seus pratos aos membros da comunidade e seria necessário acrescentar, preparados por membros da comunidade. À medida que algum desses eixos afrouxa seus laços com o étnico o outro é reforçado. Parece ter sido essa a estratégia das cantinas, já que produziam e serviam aos imigrantes italianos, à medida que os consumidores foram se dispersando, fortaleceram suas raízes imigrantes na cozinha, valorizando o conhecimento da mamma e doméstico, no entanto, perdeu sentido quando surgem novas linguagens, especialmente aquelas vindas da Itália contemporânea. A cozinha será italiana pela lealdade aos livros de receitas e técnicas e não mais pela sua produção ou pelas pessoas que a consome.

Nesse caso, como sugere Appadurai (2003) ao falar de mercadorias, o que está em jogo é que a comida italiana não é mais um bem restrito, ela se tornou mais acessível, de modo que é preciso criar um sistema de exclusividade que permita atestar um acesso diferenciado aos cosmopolitas urbanos de camadas favorecidas. Com isso, a noção de autenticidade ganha imediatamente mais força, criando mecanismos complexos de atribuição criteriosa dessa condição, nomeando experts $^{239}$, legitimadores dessa posição e que neste caso são os chefs. As diferenças de produção não poderiam nem sequer existir, pois confundiria os consumidores dessa cozinha.

Como os objetos, a comida italiana também se tornou facilmente reproduzível fora de seu contexto original, de modo que estabelecer escalas entre os tipos de comida acentua a diferença entre restaurantes e a exclusividade de acesso. Nesse caso, características mais próximas do que é feito na Itália contemporânea e preparo por mãos profissionais traria maior autenticidade à comida italiana, especialmente quando comparada ao resultado da adaptação local feita pelos imigrantes e segundo a perspectiva predominante que tende a valorizar a diferença como característica do cosmopolita.

239 Esse assunto é amplamente tratado em toda a obra de Bourdieu e em especial La Distinction (1979). 
São anos de trabalho e sabedoria simplesmente desfeitos pelos "modismos" da capital gastronômica, ao menos desde o ponto de vista dos interlocutores. Esse trajeto é parte da história dessas famílias e de sua identidade, confrontadas pelos cozinheiros que chegam impondo suas regras. Fabrizio Fasano não teve qualquer pudor em dizer que trouxe um chef da Itália para realizar uma:

O que é cozinha italiana, não essas coisas que a gente vê nas cantinas que, infelizmente, é o que pessoal conhece como comida italiana ou, pelo menos, ficou conhecendo como comida italiana. Agora a cidade mudou, a comida italiana de verdade está sendo reverenciada, antes não e nada mais injusto.

Nesse contexto, mulheres na cozinha somente como assistentes e muito ocasionalmente como chefs, nem mesmo sua opinião é valorizada, ao contrário do que ainda se vê nas cantinas, onde a memória das matriarcas e a manutenção de seu conhecimento são ainda de alguma forma reconhecido. Sua autoridade vem exatamente do fato de serem reconhecidas como "boas cozinheiras", sobretudo em casa.

Entende-se então porque alguns interlocutores foram reticentes com relação às mudanças e ressaltaram a importância de certos pratos, como o doce de São José, a zepola, um orgulho para a confeitaria DiCunto e segundo Pedro Porta,

\begin{abstract}
A primeira confeitaria a introduzir esse doce, na verdade vários doces, já que bons confeiteiros eram do sul da Itália, de onde veio meu sogro [...] e todo ano, no dia 19 de março, dia de São José, fazemos o doce e vende tudo, tudinho [...] Depois tem o panetone, fomos os primeiros junto com os Bauducco quando ainda eram donos da Dulca, a pastiera di grano [...] aquela torta feita com ricota e uva passa também fomos os primeiros a ter aqui.
\end{abstract}

Tanto Pedro, como outros entrevistados, pensam que o importante é "não inventar muita coisa, mudar as coisas sem consultar" ${ }^{240}$, na verdade uma estratégia para desautorizar os chefs de cozinha que para muitos representam problemas pelo fato de chegarem ávidos por mudanças em todos os âmbitos, pois não "seguem as receitas, querem fazer de seu jeito".

Qualidades como respeito, obediência, fidelidade são valorizadas em detrimento da criatividade e individualidade. "A cozinha italiana precisa ser inovadora, mas sem destruir nunca o que foi criado por gerações e gerações de antepassados", disse Emilio Locatelli, chef que veio com o pai de Aurélio Guzzoni em uma entrevista para o jornal Folha da Tarde $e^{241}$. Definido pela família como um cozinheiro "clássico", pois as receitas eram seguidas à risca, com alguma inovação aqui ou acolá, ele tinha a orientação da gastronomia francesa que á época era praticamente hegemônica no sentido de orientar as práticas na cozinha. Era menos uma

240 Nesse caso, as referências de homens e mulheres foram bastante similares.

241 Op.Cit. 
cozinha nacional, como hoje parece que os novos chefs tentam reforçar, e mais uma cozinha destinada para classes mais favorecidas.

A novidade, segundo Warde (1997), é um fenômeno até recente e derivou de uma lógica comercial (capitalista) que impregnou distintas áreas do saber e em especial a cozinha. Por outro lado, a tradição aventada pelas cantinas tampouco é totalmente pura como a retórica faz parecer, as adaptações locais ocorreram e criaram um repertório bastante particular de pratos, bem como do que constitui essa cozinha italiana.

As novas gerações se deparam com todas essas questões e se acirram quando há um descompasso entre as gerações e as expectativas em torno do trabalho das mulheres e dos homens. Em algumas famílias as relações permanecem ainda fortemente desiguais. Essas condições observadas de modo bastante recorrente nos restaurantes que compuseram o recorte e refletem uma situação não colocada de modo claro, mas sempre presente, a preocupação com o futuro e a perda de uma imagem construída ao longo de vários anos.

As novas gerações e, em especial as mulheres, precisam mostrar sua capacidade de dar continuidade ao trabalho de sua família e ancestrais, pressionados para "dar certo" como seus pais e avôs. As mulheres se questionam a respeito de seu preparo para enfrentar esses obstáculos, muitas vezes sem incentivo no interior da família para assumir a responsabilidade do estabelecimento, amargando vários dissabores.

De qualquer modo, o fato é que restaurantes de comida italiana hoje na cidade de São Paulo raramente são conduzidos por mulheres e quando isso ocorre, sua colaboração continua despercebida. A ausência de um reconhecimento nos leva a perguntar se de fato estamos diante de mudanças nas relações de trabalho e a cozinha parece indicar que as mulheres ainda enfrentam dificuldades nesse segmento.

O fato é que embora se afirme com veemência a igualdade de oportunidades e acessos, não é o que ocorre na realidade. As mulheres acabaram dissolvidas pelo ácido corrosivo das memórias de uma cidade que se vê cosmopolita e Capital Mundial da Gastronomia, algumas poucas encontram seu lugar, mas em geral são exceções à regra. É o legado da cozinha doméstica que permanece preso ao universo feminino, ainda que elas também trabalhem em restaurantes, sua presença permanece mais opaca que a dos homens que cozinham, embora enchendo estômagos anônimos da cidade plural.

\section{Comida italiana ao alcance de todos: pizzas e restaurantes de comida rápida}

Como visto até o momento, a cozinha italiana ganhou espaço e reconhecimento, chegando a ser considerada praticamente algo natural da cidade, uma vez que foi plenamente domesticada, 
embora nos anos de capital gastronômica as diferenças que antes a demarcavam e que se expressavam em uma dicotomia básica entre norte e sul, rico e pobre, desdobrou-se. Esse processo expressou empréstimos e intercâmbios que constituíram uma forma bastante particular de cozinha italiana com sabores locais. No entanto, a produção de localidades dessa cozinha não se limitou a uma interlocução com a cidade, nos tempos de globalização adquiriu outros contornos que trouxeram novas questões ${ }^{242}$.

Ao longo dos anos 1990 e 2000, restaurantes e comida atraíram atenção em função da explosão de opções do comer fora nas grandes cidades, bem como na "deslocalização" de produtos e receitas com maior intensidade que em décadas anteriores. Nesse sentido, levantou-se um intenso debate em torno da perda de aspectos importantes no comer contemporâneo, inclusive, uma diluição do que seria uma cozinha tradicional ou autêntica ${ }^{243}$.

É verdade que a cozinha italiana tenta passar uma ideia de coerência, tal como Capatti \& Montanari (1999) discutiram, mesmo que os regionalismos sejam e estejam por trás, não é a soma das cozinhas regionais que formará uma identidade em torno dessa culinária ${ }^{244}$. Essa é uma forma persistente no senso comum em definir uma cozinha nacional porque dá a sensação de que existe uma normalidade ou naturalidade em torno do que compõe uma cozinha. Na verdade, é uma forma de legitimar posições e camuflar conflitos, como também sugere a trajetória da cozinha italiana em São Paulo.

Massas e pizzas seriam as duas grandes categorias em que a cozinha italiana se apóia para conseguir uma imagem de homogeneidade, ícones que foram crescendo à medida que as comunidades de italianos instalados no estrangeiro precisavam de elementos para identificá-las. Esses pratos têm suas vantagens: viajam com facilidade, são feitos a partir de técnicas e ingredientes relativamente acessíveis, podem ser reproduzidos em grande quantidade por distintos produtores, tanto na esfera doméstica quanto na pública.

Emerge a partir dessas observações outra questão, a forma como se produzem distintas localidades. Houve uma trajetória em que o local ofereceu distintos pesos à comida, e não somente em termos de encontro com elementos da nova terra. A noção de localidade também estava presente nos regionalismos dos primeiros imigrantes e que se distribuíram pela cidade em bairros que congregaram esses estrangeiros, nos novos fluxos de imigrantes e novos territórios imaginários para constituir a dicotomia que marcou o meio do século

242 Para essa discussão de uma perspectiva focada na alimentação e território, consultar Bell \& Valentine (1997). Consultar o número S4, maio 2008 da revista eletrônica AoFood (htpp//: aof.revues.org/index2763.html) sob coordenação de Esther Katz e Charles-Edouard de Suremain que trata em profundidade essa questão.

243 São vários os autores que levantaram aspectos da alimentação contemporânea, mas um interessante traçado é fornecido pelo trabalho de Contreras \& Arnaíz (2005).

244 Duhart (2004). Para essa questão analisada sob um foco mais específico consultar Appadurai (1988) sobre cozinha indiana e Pilcher (Op.Cit.). 
XX, bem como os novos fluxos globais. Sentidos anteriores não desaparecem, mas se vem justapostos a novos formando um conjunto de espaços e tempos convivendo entre si.

Essa questão, como foi possível entrever no tópico anterior, não ignorava a origem dos italianos e essas eram colocadas no prato, mas escolhas foram feitas para reafirmar certas identidades e descartar outras. A cozinha italiana foi inserida no fluxo da vida social dos imigrantes e correspondeu no estreitamento de relações entre italianos, na construção de uma nova localidade que se tornou peculiar para a capital paulista, mas potencialmente menos verdadeira que a nova cozinha exercida em restaurantes que começou a despontar no fim dos anos 1980. O que ela não diz é que também esta longe de seu berço e, portanto, já também diluída em sua veracidade.

O caso da cozinha italiana talvez seja mais elucidativo porque se alastrou pelo mundo de forma incrivelmente rápida e bem aceita. Desse modo, criou distintas localidades em função do contato entre grupos de imigrantes, mas também em função dos restaurantes, pois no mundo atual a reprodução de uma cozinha está muito menos dependente de seu vínculo étnico. Ela pode ser reproduzida com maior facilidade em função de um conhecimento que circula velozmente, pela legitimidade que os livros de receitas concedem, pelas viagens e pelos cursos disponíveis.

A localidade associada à temporalidade na cozinha produziu um embate entre cozinhas na capital gastronômica e que, do ponto de vista da imigração, fala de formas diferentes de adaptação e os novos vínculos com a Itália contemporânea. Nesse sentido, o local associado ao tempo irá produzir cozinhas com sabores muito distintos, falará sobre posições que muitas vezes nem sequer se desejam que fiquem próximas.

O caso da pizza é interessante. Apesar de ter surgido praticamente lado a lado com as massas, o descolamento de sua trajetória da cozinha italiana é evidente e foi transformada em um ícone urbano paulistano e, talvez, seja uma forma de reconhecer a cidade tão ou mais forte que seus restaurantes. Consumir pizza é mais acessível e já é um produto incorporado ao repertório alimentar atual, o que difere a pizza paulistana é sua relação com imigração que parece conceder mais autenticidade se comparada a outras pizzas nacionais, sendo inclusive tida por alguns interlocutores como melhor que na própria Itália ${ }^{245}$.

Comer pizza hoje é um hábito comum pelo mundo, tendo alcançado imensa popularidade. No Brasil, os primeiros sinais da pizza foram dados por volta do início do século XX junto com

245 A pizza paulista é até vendida até em pousadas no interior do País, folheando uma revista de turismo ecológico que circula basicamente na região Centro-Oeste, uma das propagandas de restaurantes em Alto Paraíso, Goiás era: “A $1^{\mathrm{a}}$ pizzaria com forno à lenha e a qualidade da pizza paulista!” Ao lado de uma foto do forno e de uma pizza, indicando que a genealogia italiana está incorporada, porém diluída frente à origem paulista. $\mathrm{Na}$ Internet, pesquisas rápidas mostraram diversos sítios falando sobre o assunto, além de associações como o Clube da Pizza, fundado nos anos 1990 com o intuito de preservar a tradição da pizza na cidade ou a Associação da Pizza Napolitana entre outras. 
os primeiros imigrantes italianos. Nesse ambiente fertilizado pelos encontros entre diversas etnias, o uso da pizza rapidamente foi incorporado como emblemático do grupo, embora não tenha ficado contida aos limites dos bairros normalmente associados à comunidade italiana. É um produto tão comum na cidade que nos anos 2000 o consumo de pizzas atingiu 42,9 milhões de unidades por mês, contando com 5850 pizzarias, números de estabelecimentos que só perde para a cidade de Nova York ${ }^{246}$.

Pizza também não era um produto conhecido entre todos os grupos que vieram para São Paulo. Segundo Capatti (2001), a palavra pizza aparece em alguns registros de 997, primeiramente encontrada em manuscritos dos arquivos da catedral de Gaeta, usada naquele momento como uma forma de pagamento junto a porcos e frangos, embora não fique claro como era preparada. Há registros que a apontam como uma massa fina de farinha e ovos frita na manteiga e salpicada com açúcar, servida em banquetes e consumida com as mãos, receita que normalmente constava dos livros de famílias mais favorecidas, contudo pouco além é possível saber. Não se sabe se era consumida em casa ou em estabelecimentos ou vendida na rua, apenas séculos mais tarde, a palavra pizza aparece mencionada em um conto napolitano, publicado em uma antologia de 1634, sugerindo um tipo de consumo comum ao longo da jornada de trabalho, porém sem açúcar ou amêndoas como nas cozinhas opulentas.

Nessa trilha apontada por Capatti (2001), até meados do século XIX a situação da pizza não diferiu muito, a não ser em Nápoles, onde a palavra pizza circulava já com alguma intensidade e descrevia três produtos: uma massa fermentada, temperada e cozida no forno de pão (a pizza propriamente dita); um pedaço da mesma massa, fina, frita, podendo ser salgada ou doce (pizella); uma espécie de torta com ovos, presunto e ricota com ou sem açúcar (pizza rústica).

A pizzella era consumida rapidamente após sair da fritura, normalmente coberta por tomates e orégano, parmesão ou anchovas. A pizza rústica era recheada com algum laticínio ou ovos, podendo também vir com ricota ou açúcar, sendo vendida em lojas especializadas, embora neste caso, fosse um produto de consumo associado às festas domésticas. Em 1891, Pellegrino Artusi, já mencionado anteriormente, fez referência à "pizza napolitana" ainda como uma espécie de torta com açúcar e amêndoas. Posteriormente, algumas referências indicaram que, ao contrário da realidade encontrada no norte da Itália, a pizza napolitana podia ser consumida em estabelecimentos populares, como as trattorie ou osterie, como apontou Helstosky (2004), além dos bistrôs chamados pizzerie.

Em Nápoles existiam registros de locais que vendiam pizzas, espécie de padarias que garantiam a venda direta desse produto, além de preparar e cozinhar macaroni. Não era uma comida para ser consumida no local, era levada para a rua ou para os pequenos estabelecimentos em que as pessoas se sentavam e pediam uma bebida, normalmente vinho, para acompanhar sua 
pizza. Contavam ainda com ambulantes que percorriam a cidade de ponta a ponta oferecendo as pizzas aquecidas em recipientes. Nada se menciona sobre a mussarela ou o tomate, mas sim que era consumida com as mãos e algumas vezes, dobrada em quatro como uma folha de papel.

Esses estabelecimentos foram adquirindo novas configurações e se transformaram em pequenos restaurantes com comida sofrível e preços acessíveis, sobretudo em meados do século XIX. Mas, em função disso perderam bastante de seu aspecto apetitoso, inclusive porque os produtos ficavam dispostos em balcões pouco higiênicos e assediados por enxames de moscas, misturados ao mau cheiro proveniente das ruas estreitas e sujas. Decrescendo no interesse popular, inversamente a pizza estimulou a curiosidade entre camadas privilegiadas.

Pizza, segundo ainda sugere o autor, era uma comida predominantemente consumida fora de casa, pois era uma forma de apaziguar a fome de estômagos populares. No entanto, membros da nobreza e famílias aristocráticas começaram a organizar eventos em suas casas para degustar pizza, uma vez que suscitou a curiosidade de camadas mais privilegiadas que contratavam os serviços de especialistas no preparo da pizza e se fundou um próspero negócio, o serviço de refeições feitas nas casas. Em 1832, segundo Capatti (2001), Fernando II contratou o pizzaiolo Antoine Testa para servir seus convidados no palácio de Capodimonte e apresentar o sabor "ordinário" da pizza às damas da nobreza. Em uma cerimônia similar foi criada a pizza mais famosa do mundo, Margherita, elaborada pelas mãos de Raffaele Espósito para a esposa do rei da Itália, em 1889. Ambos os pizzaiolos conseguiram fundar prósperos negócios e abriram espaço para uma atividade até então pouco explorada.

De qualquer forma, a pizza em Nápoles tinha um significado relacionado à pobreza e à forma como era possível facilitar a vida dura e rústica da maioria da população. Esse significado será rapidamente sobreposto a novos sentidos, especialmente nos primeiros anos do século XX, quando os restaurantes assumem a venda majoritária da pizza, inicialmente em estabelecimentos pouco atrativos, mas à medida que o gosto pela pizza se difundia entre camadas mais privilegiadas, inúmeros estabelecimentos sofisticados surgiram servindo-a em mesas, sobre pratos e consumida com talheres. No entanto, a pizza permanecia uma comida regional, em Milão, por exemplo, Capatti (2001) apontou que em 1930 não se encontravam mais que sete estabelecimentos que vendiam pizzas, situação que perdurou até os anos 1960, situação revertida apenas em 1990, quando serão mais de 400 estabelecimentos.

Assim, de um alimento para tapar a fome entre as principais refeições, ou às vezes substituindoas, a pizza se consolidou no gosto popular, mas conquistou novos paladares, sobretudo em camadas mais favorecidas. A sua difusão contou, ainda com a grande emigração italiana para países como Estados Unidos, Brasil e Argentina iniciada no fim do século XIX e início do século XX. 
Diante disso, a pizza adquiriu diversos sentidos nos países que absorveram imigrantes italianos. No Brasil, o popular prato adquiriu seu formato padrão, redondo, mas outros formatos e denominações surgiram na Argentina, por exemplo. Ali, a denominação pizza era dada a uma massa mais alta, coberta de molho de tomate e queijo e mais parecida com um pão, cortada de forma retangular. Atualmente é possível encontrar a pizza redonda, até pela intensa globalização do produto, mas no vizinho Uruguai a diferença permanece. Nesse país, pizza corresponde a essa espécie de pão coberto e pizzetta ao disco redondo, embora de tamanho bem reduzido, similar à pizza conhecida como brotinho, que possui massa mais fina com cobertura de queijo e outros ingredientes como cogumelos, presunto ou tomate, sempre com bastante orégano. Nos Estados Unidos a pizza é bastante similar à encontrada no Brasil, embora tenham surgido redes de fast-food que alteraram o aspecto, algumas semelhantes ao que chamamos de torta, com massa alta e fartamente coberta por legumes, queijo ou calabresa.

O formato redondo foi em parte obra dos inúmeros napolitanos que se concentraram na cidade de São Paulo e, em especial, no bairro do Brás. Don Carmeniélo, napolitano, parece que foi o primeiro a trazer a pizza para sua modesta cantina aberta em frente à sua casa, segundo Sesso Jr. (1995), servindo a "mezzo a mezzo" (aliche e mussarela) acompanhada de vinho. Outras cantinas seguiram o exemplo e mais tarde, quando Dom Carmeniélo faleceu em 1943, no mesmo lugar foi aberto outro estabelecimento, a "Pizzaria do Luiz", que funcionou até 1968.

Por outro lado, ao contrário do que é normalmente compartilhado no senso comum, a pizza demorou algum tempo para entrar com força no cenário paulistano e brasileiro, uma vez que uma boa parcela de imigrantes que chegou entre 1876 e 1902 foram fundamentalmente de vênetos e estes não tinham hábito de consumi-la.

A entrada desse prato, na verdade, não está bem registrada, Sesso Jr. (1995) narrou sobre a cantina de Don Carmeniélo, mas também há menções de vendedores ambulantes em outros observadores, inclusive Jacob Penteado (2003) se refere ao italiano que vendia pizza em pedaços pela rua carregados em latões, cujo fundo era aquecido por brasas. Penteado (2003) descreveu o pizzaiolo, um italiano que circulava pelo Belenzinho vendendo suas pizzas. Era um senhor que carregava uma enorme lata redonda às costas com brasas e discos de pizzas, cortadas em quatro pedaços, cada qual por 200 réis. Para vender seu produto o anunciava a plenos pulmões: “Ó pizzaiolo, é cavora! Aliche e pomarola!" (Apud: 209), as crianças e outros transeuntes compravam seu lanche e o consumiam pela rua.

Este último meio de comercio era muito comum, como foi visto no primeiro capítulo. Abrir um pequeno negócio voltado à alimentação era uma opção entre imigrantes com pouca instrução e profissão formal, surgindo pequenas fábricas e lojas. Aqueles com menos condições ainda buscavam trabalhos que envolviam coleta, compra e venda de produtos tais como jornais, 
garrafas e produtos comestíveis ${ }^{247}$. No Brás, a colônia napolitana se dirigiu em peso e foi ali, segundo Sesso Jr. (1995), que surgiu a pizza que se aproveitou dos bareses (nascidos em Bari, Puglia) para ser vendida, uma vez que estes predominaram como vendedores ambulantes.

O abastecimento desses vendedores, no entanto, não era feito exclusivamente pelas cantinas. Em São Paulo, outro estabelecimento que popularizou a pizza foi a padaria. Esse fato ocorreu uma vez que até meados do século passado, os italianos foram os principais proprietários desse tipo de comércio e forneciam o produto aos vendedores ambulantes, especialmente nos dias de jogos de futebol ${ }^{248}$. Um pizzaiolo famoso e que seguiu essa cartilha foi o espanhol Valentin Ruiz que preparava imensas quantidades de pizza na Padaria Santa Cruz, no Brás. Foi ele, inclusive, que ensinou o ofício a outro italiano que mais tarde ficou bastante conhecido na cidade, Giovanni Tussato, o Babbo Giovanni que teve diversas pizzarias e preparou uma imensa quantidade de profissionais, pizzaiolos que se esparramaram pela cidade, quase todos nordestinos ${ }^{249}$.

João Donato se lembrou de todas essas passagens ao contar sobre sua infância no Brás. Era comum ver os vendedores de pizzas com seus latões nos jogos de futebol promovidos no bairro do Brás, já que vinham torcedores de todas as partes da cidade que rapidamente acabavam com o estoque dos vendedores ${ }^{250}$, especialmente quando os times eram populares.

A produção de pizzas foi inspirada em um modelo familiar similar ao visto nas cantinas, inclusive no início não representavam negócios distintos, a não ser quando as padarias tomaram boa parte da produção de pizzas e as saíram distribuindo. Boa parte das cantinas servia massas e pizzas, como até hoje a Pizzaria Castelões, Pizzaria Speranza, a cantina Jardin di Napoli.

Nos anos 1950, ainda, houve uma mudança com relação à pizza, pois foi o ano em que entrou em cena um tipo diferente daquela que circulava normalmente e conhecida como napolitana ${ }^{251}$. Em 1956, é inaugurada a Pizzaria Monte Verde, instalada na divisa entre Bom Retiro e Barra Funda, dois bairros associados à imigração italiana no começo do século XX, servindo pizza de massa fina, "à moda de Roma”. Segundo seus proprietários, uma novidade ao "modismo" da

$247 \quad$ Consultar o trabalho de Hutchinson (1960).

248 Bertonha (2005) aborda esse aspecto rapidamente em seu trabalho.

249 Em outro depoimento, João Malagueta, dono da Pizzaria Venite, diz que os primeiros a vender pizza foram os padeiros, ele mesmo aprendiz de Valentin Ruiz há mais de 60 anos. Retirado da Internet em 24/04/2008 do sítio: www.colibri.br/inside2/default.asp?cod_materia=538\&catg+14\&edicao+6\&htm

250 Franco Ravióli, dono da Pizza Bros, comentou que seu pai e tios se lembravam dos latões com braseiros a carvão onde circulavam as pizzas e que era um lanche consumido a qualquer hora do dia. Esse depoimento consta no sítio da Internet retirado em 29/02/2008: www.italiaoggi.com.br/gastronomia/saibamais/ita_gastro_ saibamias33.htm.

251 Recentemente o Parlamento italiano preparou um projeto de lei para definir o que é uma pizza napolitana. Em um texto com três páginas de extensão, oito artigos e seis cláusulas, os políticos querem banir imitações definindo as regras de elaboração da verdadeira pizza napolitana. O texto decreta que deve ser redonda e seu diâmetro não pode ser superior a $35 \mathrm{~cm}$. O centro da pizza não deve superar 3 milímetros de espessura e aborda não pode ultrapassar dois centímetros. Queijo especial, massa feita à mão e forno a lenha são outros aspectos abordados no documento. Para mais detalhes consultar o mesmo sítio acima citado. 
massa grossa, uma massa fina e leve para a pizza ${ }^{252}$. Capatti (2001) não chegou a comentar essa distinção, mas é possível que essa massa tenha origem também no sul da Itália pela trajetória que ele traçou em torno dos preparos, algumas massas bastante similares ao biscoito, finas, mas não tão consistentes.

O passado popular da pizza não é negado, sem dúvida começou como uma comida servida de modo simples, para um consumo de passagem, em pé e com as mãos. A sua transformação ocorreu quando pulou para as mesas e começou a ser servida em pratos e consumida com talheres, passagem descrita por Capatti (2001) em Nápoles.

Paola contou que no começo sua avó abriu uma pequena porta onde vendia as pizzas em pedaços e as pessoas comiam em pé. Foi ficando mais e mais conhecida e as pessoas se aglomeravam na calçada e decidiu abrir um restaurante no bairro do Bixiga, para ela o "mais italiano da cidade" na época e onde está até hoje. Nesse novo empreendimento com estrutura ainda predominantemente familiar passou a servir pizzas nas mesas, com toalhas de mesa, talheres e pratos, ganhando ares de refeição formal. Ao lado das pizzas eram servidos antepastos, pães e massas, ampliando as opções para famílias que começavam a sair de casa para comer. Sem cobrar preços de restaurantes refinados atendia famílias de camadas médias que mudavam seus hábitos frente às mudanças que transcorriam na cidade.

Esse modelo também foi seguido por outras casas, o próprio João Donato comentou que a pizza só foi integrar o cardápio da Castelões entre os anos 1930 ou 1940, "não tenho certeza", disse. Antes disso o estabelecimento era uma cantina especializada em algumas massas e frango capão. E a pizza já não era mais meramente uma comida de rua.

A dicotomia vista anteriormente, entre regiões norte e sul, bem como seus representantes, reaparece nos anos 1980 também na pizza, quando a massa grossa ficará associada à velha guarda e a massa fina como uma forma "moderna" de comer pizza, especialmente quando houve o boom das pizzarias elegantes nos anos 1980. Surgiam estabelecimentos localizados em bairros nobres, como os Jardins, e se opunham totalmente aos estabelecimentos tradicionais. Inclusive introduziram a moda de pizza individual, algo que até então não se conhecia. A mais conhecida foi a Pizzaria Cristal, de propriedade de Carlos Rios que comentou ${ }^{253}$, "Queríamos algo diferente, sem azulejos nas paredes, sem barulho. Tínhamos até copos de cristal" e teve um verdadeiro apogeu ao longo dos anos 1980. Mas Afonso Roperto vai além, para ele a distinção entre massa grossa e massa fina é entre "pizza napolitana e pizza paulista, embora hoje não tenha como separar".

252 Segundo o mesmo sitio em que João Malagueta deu depoimento, a massa fina parece que já era conhecida bem antes da pizzaria Monte Verde, pelas mãos de Bruno Bertucci e a Pizzaria do Bruno, aberta em 1939 e até hoje instalada no bairro da Freguesia do Ó. Ali ele optou pela massa bem fina, assada em fôrma de alumínio untada com óleo, alguns acreditando que era pizza frita.

253 Retirado da Internet em 24/04/2008 do sítio: www.colibri.br/inside2/default.asp?cod_materia=538\&catg +14\&edicao+6\&htm. 
A novidade se espalhou entre outros estabelecimentos, como lembraram Ana Maria Carrer e Wally ao falar de um restaurante que nos anos 1980 foi um dos mais frequentados pelo seu grupo de italianos, o Restaurante Gambino. Curiosamente, elas comentaram que o estabelecimento ficava bem em frente a uma "imitação" de cantina que era denominada À Camorra. E chamavalhes a atenção por representarem coisas totalmente opostas.

O Restaurante À Camorra foi um marco no fim dos anos 1970 por duas razões, na versão delas, primeiro porque era uma cantina nos moldes tradicionais fora dos bairros italianos. Segundo, levaram ao extremo o estereótipo de cantina italiana, já que os clientes também podiam participar das músicas e canções, pois eram distribuídos pandeiros e colheres de pau para bater em pratos de metal (instrumentos musicais) que ficavam pendurados em fitas de cetim verdes e vermelhas ${ }^{254}$. Se o barulho era associado às cantinas, neste em especial foi levado a extremos. Os garçons eram vestidos com roupas do "sul da Itália" e usavam um chapéu preto. A comida: massas banhadas em molho de tomate e queijo derretido servidas em cumbucas de cerâmica ordinária.

Totalmente oposto, o restaurante Gambino que acudiam com frequência, tinha, segundo contaram, decoração elegante, atendimento formal, embora com preços convidativos, servia pizzas individuais de massa fina, além de saladas e massas em seu cardápio ${ }^{255}$. Novidade que na época fez que além alguns grupos de italianos e descendentes mais apegados à Itália contemporânea se tornassem clientes assíduos, ao lado de novos comensais locais que apreciavam a proposta do restaurante e pizzaria.

Eram novos tempos, já que se estabelecia um diálogo com a valorização de escolhas cada vez mais individualizadas e traziam alternativas mais saudáveis no cardápio. E também representavam uma nova modalidade de empreendimento, menos familiar e mais "empresarial" já que as inúmeras pizzarias que seguiram esse modelo eram abertas por vários sócios sem qualquer vínculo entre si a não ser o interesse de prosperar com o empreendimento. É verdade que com isso a vida útil era, em geral, bem menor, pois não foram poucos os estabelecimentos que abriram e pouco tempo depois fechavam ou eram vendidos.

Foi nessa época também que surgiram novas coberturas de pizzas além da tradicional mussarela, aliche e margherita. Segundo contou João Donato, as "invencionices" surgem quando essas novas pizzarias abrem nos bairros "chiques". A primeira pizza de catupiry parece que saiu dos fornos da Pizzaria Margherita, inaugurada nos anos 1980, fiel à massa grossa.

254 Devo confessar que me lembro muitíssimo bem desse restaurante, pois a primeira vez que fui devia ter por volta de 10 anos e fui convidada por uma colega de classe que decidiu comemorar seu aniversário ali, por ser um lugar, segundo sua mãe, "na moda". Eu e mais 6 ou 7 colegas de escola fomos juntos e adoramos o barulho, bater nos instrumentos com as colheres e cantar com o conjunto vestido de italianos do campo a Tarantella. Era fim dos anos 1970 .

255 Como tinha preços razoáveis, era o restaurante em que meus colegas de faculdade costumavam jantar depois da aula e algumas vezes os acompanhei. 
Em seguida, apareceram pizzas cobertas com frutas e caldas de chocolate, além daquelas com palmito, quatro queijos, frango, atum etc. Antonio Carlos Marino disse que em seu restaurante anterior, La Toscanina, já servia cobertura de banana e canela desde o fim dos anos 1960.

Nos anos de capital gastronômica os sabores da pizza se ampliaram, oferecendo coberturas até então inusitadas como alcachofras, tomates secos, aspargos, queijos diferenciados que, em boa medida, dialogam com os novos ingredientes que surgiram na cozinha italiana contemporânea e tidos como verdadeiramente italianos. Além dessa diferença, os anos 1990 presenciaram a expansão dos serviços de entrega em casa, em função de um lazer de cunho mais doméstico que se delineava como resposta à escalada da violência.

Pequenos estabelecimentos localizados próximos a grandes concentrações de imóveis residenciais foram abertos, fenômeno que se espalhou pela cidade de São Paulo, assim como outras cidades do País, ampliando o acesso à pizza. Junto, houve uma oferta maior de produtos congelados, uma alternativa mais barata e fácil que permitiu a difusão desse prato com maior intensidade.

A pizza cresceu junto com a cidade e multiplicou suas versões bem como espaços onde é possível consumi-la. Criou tal importância que a pizza ganhou sua data especial, 10 de julho, uma invenção surgida em 1984, pelas mãos do então secretário de turismo Caio de Alcântara Machado $\mathrm{Jr}^{256}$. Ele justificou naquele momento a instituição desse dia porque entendia que a pizza era a "cara de São Paulo", imagem que também emerge em uma pesquisa realizada por um sítio da Internet, SP Na Mesa, em 1999. A pergunta feita, "Qual seria o prato que melhor definiria a cara de São Paulo?" e a resposta não foi quase outra resposta que pizza ${ }^{257}$. E não qualquer uma, Pizza Margherita.

Para alguns a pizza chega a ser um patrimônio paulistano, como é o tom de um artigo disponível na Internet ${ }^{258}$, cuja retórica enfatiza a pizza como introdução de imigrantes italianos, mas aprimoramento dos paulistanos. Essa percepção é bastante comum entre os interlocutores, que olham para a pizza como contribuição italiana, mas com sotaque paulistano.

Para Afonso Roperto a "pizza daqui criou uma identidade própria”, mas a pizza é, segundo a perspectiva dos entrevistados, um legado italiano para a cidade que fala novamente de adaptação, família e trabalho. A pizzaria Speranza exemplifica parte dessa trajetória que adquiriu contornos particulares que a transformaram em um prato tipicamente paulistano, ou melhor, um hábito muito peculiar disseminado na cidade. Paola, consciente que mudanças nas relações sociais favoreceram os encontros fora de casa, disse que para ela "os valores familiares estão confusos" e as mesas dos restaurantes acabaram sendo transformadas em lugares em que é possível reunir parentes. Ela contou que:

256 Inclusive 10 de julho é o dia em que o secretário comemora seu aniversário, uma homenagem feita por cem pizzarias que participaram do I Festival da Pizza da Cidade de São Paulo, em 1984.

257 Citado em http://nbjolpuc.wordpress.com/2007/11/15/pizza-o-prato-que-e-a-cara-de-são-paulo/, de 28/02/2008.

258 www.cidadedesaopaulo.com/noticias.asp?idMat=529, de 06/01/2007. 
Minha avó disse que assim se fazia em Nápoles, e é assim que deve continuar sendo feito [...] A pizzaria começou com ela, meu avô, meu pai e meus tios, Giovanni e Rita, os cinco em uma casa na 13 de Maio (rua) e foram contratados mais três funcionários, um aprendeu a fazer pizza [...] A pizza era dividida entre amigos e família, e a pizza é um momento de comemoração e estar em família é uma comemoração. A pizzaria é um lugar de encontro. [...] As famílias hoje se matam por pequenas coisas [...] a pizza é um prato que se divide, a pizza é atrativa para a família e para os amigos.

Na verdade, no início da pizzaria o negócio era fundamentalmente familiar e, embora continue com essa característica, precisou crescer para não ser massacrada pela dinâmica que se abateu sobre a cidade que presenciou a proliferação do hábito de comer fora e a multiplicação de ofertas de restaurantes.

É um novo diálogo entre a trajetória em particular de um produto de origem italiana e imigrante, e que será encaixado em um novo contexto que trava articulações não só com o local, mas com o global e o local da própria Itália. Definem sua imagem como italianos localmente, mas na Itália são vistos como brasileiros, como narrou Mario Tatini em suas memórias ${ }^{259}$, e a cozinha migra entre essas várias percepções.

Nesse caso, a comida italiana praticada na cidade de São Paulo seria italiana localmente, mas não aos olhos da Itália, pois já teria perdido os vínculos com aquilo que hoje representa a italianidade, especialmente na comida que é associada ao saudável e à cozinha mediterrânea. Em São Paulo a cozinha italiana esteve intimamente associada à imigração e seus descendentes; no entanto aqueles que viajam com frequência para o país de seus pais ou avôs, voltam redefinindo esse conceito, bem como sua própria imagem no Brasil e na Itália. Eles transitam entre distintas identidades que ora são acionadas em função dos encontros, ao mesmo tempo é reflexiva porque leva a se pensar como italiano no Brasil, mas brasileiro na Itália, reconstituindo elementos dessa trajetória que aproximam ou distanciam em cada local. E decepções são muitas vezes a tônica do comentário, pois a imagem que é feita da terra natal nem sempre corresponde ao que se encontra quando se chega na Itália ${ }^{260}$.

A cidade, capital gastronômica, incorporou esses italianos como algo próprio, mas não os distingue diretamente, nem mesmo quando diz que "a pizza é a cara de São Paulo" ou a cidade faz a "melhor pizza do mundo", ou seja, os italianos foram importantes, mas sem a contribuição local não teriam alcançado essa imagem de prosperidade. O italiano já foi domesticado, resta apenas uma menção residual que também emerge na forma como a sua cozinha é apropriada. È italiana, mas também paulista.

259 Barreto (2004). Ele conta em uma passagem que voltou de férias para a Itália com sua mulher e em uma loja, a vendedora elogiou seu excelente italiano, surpreendido pelo comentário, ele lhe disse que era nascido lá e ela desconfiada, disse que não poderia ser, já que tinha um "sotaque estranho".

260 Schneider (1996) descreveu um encontro realizado entre um prefeito de uma cidade do sul da Itália em Buenos Aires junto a descendentes daquela região e o desnível de imagens que os grupos faziam a respeito dos dois países. 
Esse aspecto está presente na memória dos entrevistados e é evidente como dialogam entre si, acionando estratégias peculiares para evidenciar o italiano como um diferencial para a cidade. No caso de algumas cantinas tradicionais instaladas no Bixiga a memória restaurou a imigração como um passo importante para a cidade e nas mesas dos bairros tradicionais ainda é possível ser degustada um tipo de comida que foi desses imigrantes, inspirada nos pratos vindos das mammas e servidos em ambientes informais.

Os restaurantes mais refinados foram prejudicados, pois sua comida não acompanhou as mudanças na cozinha praticada na Itália, como os já mencionados Ca'd'Oro e Don Fabrizio. Assim por não estarem associados à imigração da velha guarda propriamente dita perderam muito ante os novos estabelecimentos de cozinha italiana dita contemporânea, ficando em uma situação menos confortável ainda do que as já decadentes cantinas. As pizzarias também se valeram de sua história, no entanto as que se apropriaram de seu passado imigratório e abriram novos endereços parecem ter conseguido sobreviver melhor que outras que ficaram refratárias a essa estratégia.

Nesse sentido, alguns estabelecimentos tradicionais conseguiram manter sua prosperidade em detrimento de outros que praticamente sobrevivem dos minguados clientes que ainda os prestigiam. E não resta dúvida de que essa situação gera uma disputa velada entre os vários estabelecimentos. Aos que seguiram o caminho da modernidade, a acusação dos que recusaram essa opção é de "perda de qualidade", e aos que ficaram fiéis a um modelo, os que mudaram os vêem como "antiquados".

Essa percepção, um pouco mais amena, está na fala de Fábio Donato ${ }^{261}$, filho de João Donato, quando descreveu as mudanças à sua volta. Para ele, a diferença de seu estabelecimento e de outros é justamente a experiência, sua fidelidade aos bons ingredientes e ao preparo da massa manualmente, seguindo a mesma técnica desde quando a cantina começou com seu avô, responsável pelas massas. As novas pizzarias seriam como "caça-níqueis", interessadas em ganhar rapidamente o retorno de seus investimentos, embora não seja ingênuo e tenha consciência de quanto é difícil levar comensais para um bairro decadente, especialmente à noite para comer pizza que hoje está presente em qualquer canto da cidade.

A retórica não é mais étnica e a disputa transcendeu os limites da italianidade, ainda presente como tradição, mas reverenciada de um modo distinto frente à concorrência que surge apenas com o intuito de exploração comercial. Não mexer na variedade de pratos, na decoração, manter técnicas fiéis àquelas praticadas pelo avô ou outro ancestral envolvido na produção da comida é uma maneira de ganhar espaço na capital gastronômica e tentar sobreviver à avalanche de novos estabelecimentos.

261 Essa entrevista é parte de um projeto sobre a história dos restaurantes na cidade de São Paulo sob responsabilidade do Prof.Dr. Ricardo Maranhão e o jornalista Josimar Melo. A transcrição da entrevista foi gentilmente cedida pelo Prof. Ricardo Maranhão, mas infelizmente não consta data em que foi realizada, bem como o sobrenome da entrevistadora, identificada apenas como Karina. 
Mas não se controlam os frequentadores. Estes apreciam a cozinha italiana, de modo geral massas e pizzas são bem aceitas na cidade, mas criaram outras redes para atender a suas escolhas que não mais se identificam com a etnicidade ou com o parentesco. Comer fora de casa perdeu vínculos de outrora e hoje atende a distintas motivações que vão além de reunir a família, apreciar uma cozinha da mamma ou frequentar um estabelecimento elegante para ver e ser visto $^{262}$.

A memória familiar, individual, do bairro, da cidade será articulada para dar sentido à experiência e moldar uma identidade que se ressaltará pela retórica oficial para pensar a imigração, o trabalho e a família. Além disso, distintos processos de ocupação dos bairros trouxeram desdobramentos diferentes para os bairros étnicos. O Brás, nesse sentido, sofreu mais porque ao longo dos anos 1960 e 1970 viu os italianos serem substituídos pelos imigrantes nordestinos, fenômeno que não ocorreu com o Bixiga e que hoje tenta se consolidar como um bairro italiano para atrair turistas em busca de conhecimento dito cultural.

Esse processo não ficou imune ao crivo de interlocutores, especialmente aqueles que tinham algum vínculo com essas regiões. Para João Donato, o fato de ver o Brás perder suas características foi um processo doloroso, mais acentuado inclusive que o bairro do Bixiga que, segundo Afonso Roperto, esteve decadente, mas agora tenta se restabelecer como um "pedaço da história da cidade, um patrimônio". Assim, as cantinas seriam ainda espaços de imigração conservada pela força da tradição, ao menos segundo a perspectiva do interlocutor.

No entanto, tradição não se mantém sozinha e Fábio Donato já percebeu esse processo em função das dificuldades que enfrenta em permanecer no mesmo bairro desde a inauguração da pizzaria:

\footnotetext{
Não, não tem ninguém como concorrente aqui perto. Na verdade, os concorrentes são as boas pizzarias de São Paulo. Que elas hoje estão em bairros que hoje são residenciais, estão mais próximos da residência do cliente, então ele acaba indo pela facilidade, porque não é difícil ter cliente que chega e que comenta: Olha! Eu tive que ir em tal pizzaria outro dia porque aqui era muito longe eu não conseguiria vir, estava cansado e tal...
}

O bairro do Brás perdeu suas características muito mais rapidamente que o Bixiga, tomando um aspecto industrial e associado à imigração nordestina recente, dificultando articular o espaço e a temporalidade de modo que se torne um atrativo para os comensais. Estes, muito mais preocupados em encontrar alternativas próximas de suas casas ou trabalho, já contam com várias opções que atendem ao comer fora de casa, quer seja pela necessidade ou pelo lazer.

E ainda enfrentam os restaurantes novos que se valem dessa imagem para atrair comensais em bairros mais nobres e restaurantes inspirados nas osterias e trattorias italianas, no entanto

262 A questão da motivação do comer fora de casa foi analisado em Collaço (2003). 
com uma roupagem contemporânea. Em geral, optam por uma localização mais nobre e raramente possuem algum vínculo com a Itália, a não ser o cardápio e os nomes dos pratos. Garrafas penduradas pelo restaurante, mesas com toalhas de mesa verdes ou vermelhas, ou quadriculadas nessas cores, comida farta ficaram sinônimos de baixa qualidade e não compõem o léxico dos novos estabelecimentos. Nesse sentido, as cantinas não escaparam a um declínio considerável, especialmente a partir do fim dos anos 1990.

Para os entrevistados, esse tipo de novidade é imediatamente interpretado como "modismos" da capital gastronômica, já que a falta de vínculos com a cozinha italiana desmerece o resultado. Para os novos estabelecimentos, a proposta é modernizar algo que já estava decadente, inclusive Afonso Roperto afirmou que esse processo foi culpa dos próprios restaurantes, " $a$ cantina rotulou-se de popular, comida rústica, servida farta e tenta oferecer custo benefício". A questão é que a italianidade não pertence mais ao grupo, ela circula livremente pela cozinha dos restaurantes e não se envergonha da falta de subsídios espaciais ou territoriais para conceder-lhe autoridade.

A culpa, para os interlocutores, é também dos comensais que "desaprenderam a comer", mas a verdade é que o acesso às informações e aos restaurantes foi ampliado, de modo que as escolhas ficaram mais flexíveis. Mas, na verdade, é que esse processo mostra que a cozinha não poderá nunca ser considerada um patrimônio no sentido de um monumento ou um museu, ela acumula saberes de gerações e regiões que, talvez devam e possam ser preservados, mas não se fecham às investidas mais amplas, do contrário nunca teria existido uma cozinha italiana com sotaque local.

Portanto, é inócuo discutir o global e o local desde um ponto de vista que não considere esses aspectos, pois a interface entre grupos sempre existiu e sempre irá existir. O que se revela aqui é a memória como legitimadora de um determinado grupo de proprietários de restaurantes e seu papel na construção do comer fora na cidade. Quando ameaçada pelas novas linguagens que se apropriam de seus elementos descolados dessa memória, refletem sobre os caminhos a tomar.

O que se percebe entre os interlocutores é que ainda possuem uma visão que relaciona "pureza" e tradição amparada na ideia de manter o mesmo endereço e ser fiel à forma como a família instituiu o negócio. Esse aspecto ficou claro nas cantinas tradicionais e em algumas cantinas com anos de existência, como foi o caso de Paola, ao dizer que sua diferença em relação à concorrência estava justamente no peso da família e fiel ao que sua avó introduziu, mesmo que em uma nova filial.

Para Fábio Donato é saber manter o conhecimento que veio da cozinha, em torno dos ingredientes e das técnicas, já que seus funcionários estão trabalhando há anos na cantina, bem como seus fornecedores. Manter o padrão e ser fiel às receitas é também preocupação de Fábio, tal qual observada em seu pai João, com relação ao seu pai Vicente. São trajetórias distintas, já 
que na família de Paola, a transmissão do negócio e o endereço tiveram menos importância que a tradição em torno da cozinha, e diferente da trajetória da Pizzaria Castelões.

O que há em comum é um olhar desconfiado com relação à ideia de capital gastronômica e os efeitos que ela trouxe para os restaurantes mais antigos. Se de um lado a memória é preservada para atrair comensais, diga-se uma iniciativa em particular de um punhado de restaurantes no Bixiga, por outro é comum notar que a história é abandonada a favor do novo. Essa constatação ficou clara nas narrativas de vários interlocutores e que surge de maneira resumida na fala de Fábio, quando questionado quanto tempo pretendia ficar no Brás:

\begin{abstract}
Não, eu... A não ser que isso daqui... Eu acho que infelizmente no Brasil vai tem uma hora que o Brás vai acabar ficando inviável, mas eu gostaria de manter isso daqui por um bom tempo. Acho muito triste o brasileiro não ter, é... uma história gastronômica, uma história cultural, você preservar o antigo. Você vai comer no... lá na Espanha, o "Sobrino de Botín" tem, acho que vai fazer, ele é de 1800, 1725. Vai fazer 300 anos e estão lá, todo mundo contente, qualquer turista que vai, a Espanha acaba indo comer lá pela história, pelo tempo. Também na França há restaurantes antigos, tem alguma coisa na Itália, então lá eles cultuam isso, lá para eles é importante você manter o tradicional, é importante manter o antigo, aqui não. Aqui não, o antigo é descartado.
\end{abstract}

É uma relação não só entre gerações, mas de convívio entre memórias de família e da cidade. Nem todos os restaurantes antigos na França e na Espanha sobreviveram, na verdade alguns poucos o fizeram e possivelmente convivem com questões semelhantes ${ }^{263}$. Esse fenômeno parece ter ficado mais agudo em função do reconhecimento da cidade como Capital Mundial da Gastronomia, uma novidade que não estava contemplada pelos restaurantes da velha guarda.

Como disse Afonso Roperto,

No fundo, quando há algo antigo e você não quer mais, você diz, 'vamos fazer de outro jeito’. Mas eles (os pais e avôs) se sentem no $2^{\circ}$ plano e por eles não muda nada! A responsabilidade de manter algo já consolidado é muito grande, se sente o peso de errar. A dificuldade é mudar aos poucos, aumentar o restaurante [...] Alguns aspectos ficaram em $2^{\circ}$ plano, história, comida e administração tomam conta.

Como conciliar a tradição e sua suposta pureza à lógica comercial é uma questão que perpassa pela cabeça das novas gerações e não conseguem solucionar da forma que suas expectativas estabelecem. Em outro extremo, está Giovanni Tussato, o Babbo Giovanni. Aprendiz de Valentin Ruiz, ele saiu da padaria Santa Cruz e abriu seu próprio negócio, uma pizzaria que foi dele por quase vinte anos até que seus herdeiros decidiram dar novos rumos aos negócios. Nesse caso,

263 Na França, ver o caso do restaurante Grand Véfour, inaugurado no começo do século XX, conseguiu manter sua posição de estabelecimento refinado, mas hoje enfrenta dificuldades diversas, inclusive, ameaçado de perder estrelas no Guia Michelin. 
usaram a tradição para conceder franquias, ou seja, não só abriram filiais como as deixaram para que terceiros as administrem, a exemplo do sistema dos fast-foods.

Foi uma solução que muitos entrevistados condenaram, dizendo que a pizzaria perdeu muito do que representava, ficando um "negócio sem alma". Os filhos não se arrependeram e continuam oferecendo o nome, vendendo o direito ao uso da marca e ensinam como preparar as pizzas. Além disso, orientam os novos empreendedores em praticamente todas as etapas do negócio, oferecendo segurança em uma atividade desconhecida.

Essa forma de expandir os negócios foi mais comum entre as confeitarias que pertenciam às famílias italianas, como sugeriu Pedro Porta, com ares que indicavam algum incomodo ao elencar seus concorrentes. Ele comentou então da Cristallo, de Armando Poppa, e a Dulca, das famílias Garrone e Bongioanni que hoje estão espalhadas pela cidade em forma de redes de franquias. A família Bauducco optou por industrializar o panetone, introduzido por Alfredo DiCunto em 1939, mas popularizado por Carlo Bauducco a partir dos anos 1960, embora já o produzisse artesanalmente desde 1942.

Pedro Porta olha com ceticismo para esse caminho, pois prefere resguardar sua tradição no ponto de sempre, no bairro da Mooca, e expandir para outros bairros com lentidão e pelas mãos da família, a exemplo da família Tarallo. Dessa forma, ainda se está no controle do nome e das vendas, como o próprio Pedro deixa entrever:

\footnotetext{
Abrimos uma filial em 2006 no Itaim, na Rua Tapapuã, mas estamos com dificuldades de manter a loja, especialmente porque tudo é muito fresco e natural, com não tem conservante ou aditivo, a ideia é que se compre pouco, se consuma e se busque mais. $\mathrm{O}$ que acaba sendo complicado para a distribuição em outras lojas, o que não permite utilizar o sistema de franquia.
}

Pureza na comida, natural, qualidade aparecem como distintivos da tradição e estabelecem um diferencial com outras coisas ditas italianas e vendidas na cidade, ao menos é assim que as falas parecem demarcar as razões pelas quais não ampliam os estabelecimentos, abrem novas lojas ou instalam novos endereços. Há um respeito com o "fresco e natural" que contradiz a própria sociedade industrial e urbana que para facilitar produz comida rápida, ensacada, congelada, empacotada etc., sem respeitar a produção diária, manual, quase de outra época. Algo semelhante foi dito por João Donato sobre a maneira com que fabrica as massas, os embutidos e seleciona seus fornecedores.

Ele disse:

O pessoal que tem paladar apurado sabe diferenciar o que é industrializado do que é artesanal [...] O gosto mudou para pior. Porque antigamente não tinha essa facilidade dos enlatados. A dona de casa tinha que comprar o tomate e fazer o molho, a massa era feita à mão. Abre a lata, não sabe como o tomate foi colocado lá, como foi manipulado. [...] Enfia-se tudo na panela de pressão, 
isso é muito artificial, muito forçado [...] O freezer não foi boa coisa, aumenta a duração, mas não necessariamente contribui para uma melhora do paladar. Você pega uma peça de filé, limpa e congela, descongela, muda o aspecto e o sabor.

João Donato é um pouco desconfiado com relação às novidades introduzidas, especialmente equipamentos e produtos industrializados. O uso desses ingredientes é banido de seu restaurante, como forma de se obter um resultado positivo na comida. Afonso Roperto também entende esse respeito com o preparo como forma de valorizar a tradição disse que "A tradição é importante para o italiano", e reproduzir saberes transmitidos ao longo de gerações seja uma forma de restaurar vínculos que estão sendo esmaecidos rapidamente pela corrosão cosmopolita, mas também pelo trânsito entre descendentes e Itália.

A cozinha e o restaurante refletem as decisões quanto ao rumo tomado, continuar ou inovar são questões que abalam a própria imagem que os interlocutores fazem de si, inclusive, das relações entre familiares e de seu estabelecimento com relação à cidade. Relacionado a isso, o impacto sobre os comensais também é um aspecto que paira com insistência nas narrativas, pois se de um lado a inovação é necessária, como muitos comentaram, por outro, existem coisas que não deveriam ser alteradas.

O medo e a apreensão de ver o declínio de seu trabalho exposto no restaurante é uma das situações mais constrangedoras e que para muitos que vivem um pouco dessa situação, a fonte de consolo são os velhos tempos, mas invocados de maneira muito diferente entre pais e filhos. Os pais falam com nostalgia, os filhos se apegam como o exemplo a ser seguido.

A manutenção dessa aura é também alimentada pela mídia, como lembrou Aurélio, e isso chega a ter um peso ainda maior. As imagens que foram incorporadas ao discurso dos entrevistados estão situadas em uma época em que os restaurantes de São Paulo eram um punhado de estabelecimentos e que ante o crescimento da oferta, maior e mais variada, não houve a contrapartida em qualidade, ao contrário, torceu o gosto local que se acostumou com "porcaria".

A questão do novo acentuou ainda mais a questão do tradicional, muitos não acreditaram na nouvelle cuisine que não vingou na cidade, tendo chegado, inclusive, atrasada quase quinze anos. Mas, outras tiveram sucesso como o carpaccio no lugar do estrogonofe, a carne grelhada no lugar do Steak Diana.

A pizza ganhava espaço em diversos pontos, em entregas e novos estabelecimentos, multiplicando a oferta bem como as coberturas e possibilidades de escolher entre massa fina e massa grossa. O macarrão também surgia com uma roupagem completamente diferente, ganhava ares mais refinados, como afirma a reportagem do jornal O Estado de São Paulo ${ }^{264}$.

264 "Viva o Macarrão", Folha de São Paulo, 09/04/1989, sem autor definido. 
Além do já mencionado La Vecchia Cucina, de Sergio Arno, surgia o Spaghetti Note que servia apenas pratos de espaguete com diferentes molhos e instalado em uma "casa escondida" no bairro de Vila Nova Conceição (próximo ao Parque do Ibirapuera); In Citta, cuja cozinha estava sob comando de uma mulher, Monika Galloni, reconhecida pela sua habilidade em trazer refinamento à cozinha italiana, além de outros que "renovavam o cenário da comida italiana". Além disso, antigos donos de estabelecimentos recém saídos de brigas com sócios ressurgem como Giovanni Bruno com seu Il Nouvo Sogno di Anarello ${ }^{265}$ e Piero Grandi ${ }^{266}$ com a Cantina do Piero, ambos fiéis ao modelo de cantina já um pouco deturpado.

Era na verdade, o início de novos tempos, já que "A cultura da boa mesa está no seu início" ${ }^{267}$, ou seja, São Paulo ainda não tinha as características de uma capital gastronômica, mas tentava oferecer boas opções, ainda representadas pelos tradicionais restaurantes italianos, presentes em sua premiação da década (1980-1990). O autor menciona o restaurante Ca'd'Oro em três categorias: melhor restaurante, melhor chef (Emilio Locatelli) e melhor maître (Ático Ático Alves de Souza), embora nenhuma referência seja feita às cantinas, aparentemente um pouco desgastadas.

A reportagem também apontava para mudanças no comer local: maior preocupação com o atendimento, maior número de pessoas comendo fora e precisando ser atendida, uma procura por comidas mais leves, a utilização de ingredientes melhores e mais frescos, grelhas nos restaurantes e contas mais acessíveis. O que não deixa de ser instigante, uma vez que a velha guarda dizia usar ingredientes frescos e de boa qualidade, embora os pratos resultassem "pesados", especialmente quando mencionaram saudades dos tempos em que "ninguém estava preocupado com dieta, colesterol, diabetes, essas coisas", disse Ângelo Luisi.

$\mathrm{Na}$ verdade, a má qualidade atribuída às cantinas parece estar nessa classificação, comida pesada, mesmo preparada com bons ingredientes. Não somente em termos do saudável, mas também em função da rapidez, pois em geral era uma comida para o almoço e esse horário estava ficando com tempo reduzido e precisava de novas opções para acompanhar a transição do comer doméstico para outro fora de casa. Entretanto, os interlocutores que entrevistei não percebiam essas mudanças, ou se as viam, não fizeram menção, com exceção de Mario Tatini que fala em suas memórias:

O perfil da clientela da família Tatini não mudou, desde os tempos de Santos, [...] cliente passou a ser mais contido, mais seguro. Por outro lado, o paladar da clientela mudou. Muito. Desde a vida dos Tatini da Itália, houve uma forte

\footnotetext{
$265 \quad$ A história desse nome e de como foi parar na Vila Mariana está contada em Giovanni Bruno (1994).

266 Piero foi garçom de Giovanni Bruno em seu restaurante da Rua Santo Antonio, aberto logo que saiu do Gigetto, e em seguida conseguindo uma promoção como gerente.

267 "Os prazeres e desprazeres da comilança", jornal O Estado de São Paulo, 29/12/1989, de autoria de J. Curnonski (pseudônimo).
} 
evolução. O brasileiro, nos anos 50, era mais simplório. Um bonito filé de peixe fresco, um belo filé com dois ovos em cima, ou com molho acebolado, ou ao alho e óleo; uma torta de palmito faziam sua lista de especialidades. Sem dúvida, são pratos muito bons, mas sem requinte. E requinte foi o que se trouxe, desde os primeiros dias do Don Fabrizio [...] Esses clientes primeiro foram educados a comer. E hoje, o brasileiro tornou-se exigente. Viaja e sabe selecionar. Criticar com sabedoria. Distinguir entre sabor e apresentação. (BARRETO, 2004 p.164)

Não era uma questão somente de comida, como muitos dos entrevistados parecem concentrar as justificativas de seu declínio. Além da localização, serviam uma comida inapropriada para ter de voltar depois para as atividades rotineiras, nem sempre trazendo a comida rapidamente, apesar dos preços ainda acessíveis, mas pensados para a família. Escolher individualmente, como nos restaurantes self-service, com sistema de bufê ou peso, assim como as recentíssimas praças de alimentação, traduziu para os novos comensais o reconhecimento de seus interesses. A tradição tão cara aos interlocutores passou despercebida entre os comensais.

O foco na cozinha ainda perturba os entrevistados, uma vez que é ali onde está o coração da comida e não nas opções deturpadas que surgiram na capital gastronômica. As famílias italianas e seus restaurantes não eram mais as legítimas detentoras do saber cozinhar pratos italianos, bem como as pizzas saíram do seu âmbito de ação. Em parte, porque o saber cozinhar foi transferido aos novos cozinheiros, nordestinos em sua maioria, ou os próprios chefs e também porque restaurantes começaram a surgir pautados por novas dinâmicas urbanas. Acompanhar ou parar dependerá de como os proprietários de cantinas, pizzarias e restaurantes tradicionais pensam sobre a passagem do tempo e sua relação com um imaginário que envolve duas nacionalidades, Brasil e Itália; um local, São Paulo; o tempo que passou, bem como sua relação com o trabalho e família.

\section{A cozinha italiana na capital gastronômica}

As relações familiares amplamente transformadas em função dos novos arranjos contemporâneos trouxeram desdobramentos em várias frentes: entre os proprietários e as gerações que os sucedem, entre os comensais e suas famílias, um aspecto constantemente ressaltado nas narrativas. Nesse caso, há ainda o agravante de que as novas gerações não olham somente para o local, como talvez seus pais que ainda viam em São Paulo oportunidades para crescer, mas vislumbram fora do País e, em especial na Itália, oportunidades que pensam não existir aqui.

O retorno dos descendentes de italianos ao país de origem de seus pais e avós talvez tenham mudado visões a respeito da italianidade e da comida, evidentemente distanciadas na 
metrópole, que não se vale mais da etnicidade para conceder autoridade à cozinha quer fosse pela frequência de comensais, quer fosse pela produção que passava pelas mãos dos patrícios. Além disso, diferenças entre classes também marcaram o distanciamento de italianidades, embora compartilhassem em comum o valor à família e ao trabalho.

$\mathrm{Na}$ verdade, o processo que desencadeou uma nova valorização da cozinha italiana, em especial tradições locais, foi o fenômeno da globalização. Com a crescente circulação de cozinhas, pois não foi só a italiana que ganhou o mundo, mas outras tantas foram surgindo em diversos países e, sobretudo, na forma de restaurante fast-foods cristalizaram uma ojeriza em alguns países europeus de tal que até movimentos destinados a preservar cozinhas emergiram e, em especial, o Slow Food.

Fruto de uma luta que se diz engajada com a cultura de pequenas comunidades, teve uma ação bastante pontual ao emergir como resposta à homogeneização da alimentação mundial em função do cenário italiano no fim dos anos 1980. Dessa forma, em 1989, surgiu a primeira associação desse movimento e atualmente conta com representantes em vários países. Prega o retorno ao comer consciente, privilegiando produtos próximos, de preferência de pequenos produtores. Para tanto, se preocupa ainda em registrar produtos "em extinção" em uma "arca do gosto" que terá depois um programa específico denominado fortalezas que basicamente terá como prioridade reunir produtores, tentar divulgar e assegurar sua sobrevivência, por meio de preços razoáveis ${ }^{268}$.

$\mathrm{Na}$ verdade, é preciso pensar que local está sendo abordado, pois como já discutido anteriormente, a produção de localidades passeia pela articulação temporal e evoca distintas cozinhas que nem sempre foram moldadas em um contínuo, como ficou claro com a cozinha italiana praticada na capital paulista. A resposta do movimento foi uma reação direta à homogeneização de sabores impostos pelas indústrias e grandes conglomerados agrícolas, interessados em produzir poucos produtos destinados ao processo fabril.

O interesse em torno da gastronomia não foi um fato isolado, como se pode notar nas várias ações ocorridas em distintos momentos e espaços. É fato, no entanto, que a partir da globalização houve um estímulo no sentido de pensar a questão, multiplicando-se de várias formas o interesse sobre o assunto. Surgem mais e mais revistas especializadas, especialmente sobre vinhos, programas de TV, conversas entre amigos, viagens, produtos acessíveis já que circulam com maior facilidade ${ }^{269}$.

268 No Brasil existem alguns projetos sendo conduzidos junto ao movimento, em especial levantamentos em torno de produtos e técnicas que estão perdendo espaço frente às dinâmicas contemporâneas do preparo e consumo de alimentos. O trabalho pode ser consultado no sítio www.slowfoodbrasil.com.br, contando inclusive com uma comissão nacional para decidir sobre os itens que serão incorporados.

269 Warde (1997) e Mennell (1996) abordaram essa questão, bem como Canclini (2005) sob uma ótica que não necessariamente fala sobre alimentação, mas permite transpor algumas ideias para esse universo. 
Curiosamente, se por um lado há uma suposta homogeneização de sabores, por outro, exalta-se a diversidade cultural como inspiração máxima do cosmopolita ${ }^{270}$, e que não passou despercebido ao conceder o título de Capital Mundial da Gastronomia a São Paulo. São duas forças jogando sobre um mesmo campo com efeitos devastadores para uns, como os restaurantes da velha guarda e positivos para outros, novos estabelecimentos como restaurantes self-service, de comida rápida, de comida japonesa etc.

Em termos de apreciação, no entanto, se o restaurante está mais próximo ou não da modernidade não parece dizer respeito à comida que serve. São Paulo ainda oferece quase $70 \%$ dos restaurantes listados em guias e roteiros com algum tipo de cozinha italiana ou com seus pratos, como já havia dito Aurélio Guzzoni, fora as pizzarias. O restante é para ser dividido com outras cozinhas, revelando que a diversidade é mais um recurso retórico que uma prática efetiva.

A cozinha italiana então se depara com vários planos de ação, a comida servida nos restaurantes da velha guarda se há tradição, há também um exalo de "coisa antiga" como disse Fabrizio Fasano, mas isso não implica que a cozinha italiana não continue a predominar no cenário paulista. Agora a comida italiana que encontrará espaço é aquela que dialoga com a Itália moderna e que chega arejando as velhas receitas.

Não se trata de um gosto naturalmente adquirido em função do número de italianos, até porque muitos não mantêm quaisquer vínculos com a Itália, a não ser como uma referência espacial. Na verdade, para muitos entrevistados "ser italiano" é valorizar uma história local e familiar, e na qual a comida desempenha um fator de reconhecimento. Os descendentes já mais diluídos em seus vínculos, não hesitam em ir para a Itália conhecer suas raízes e renovar sua italianidade, muitas vezes pela comida, reconhecendo a cozinha italiana sob dois prismas: um espacial - Itália -, e outro temporal - imigração. Não se excluem, mas delimitam distintos reconhecimentos.

Essa postura diferencia a cozinha italiana praticada em São Paulo e a cozinha italiana praticada na Itália. Em São Paulo são conhecidas as diferenças regionais entre as cozinhas italianas, mas acabaram em boa parte fundidas em função da experiência em comum que os imigrantes compartilhavam. Não é raro encontrar nos cardápios de restaurantes de cozinha italiana pratos do sul, do norte, do meio da Itália sem qualquer cerimônia convivendo pacificamente. O espaço ainda diferencia origens, mas é no tempo que a cozinha local interpreta seu maior trunfo e a fissão de distintas experiências emerge condensada na comida que agora se volta mais uma vez às origens deixadas para trás.

A cozinha italiana é como um porto seguro ante os novos sabores que chegam à cidade cosmopolita e desperta segurança aos comensais, mesmo que não italianos. Esse ponto também

$270 \quad$ Hannerz (1992). 
pode ser observado na análise feita por van Otterloo (2002) quando discute a gênese de uma cozinha internacional e um gosto pelo "exótico" na Holanda.

A aceitação de novos sabores não é um processo que possa nem mesmo ser previsto, pois gera distintas relações que serão incorporadas em maior ou menor medida à comida. Mas, se o consumir é uma forma de distinguir, é também forma de aproximar, e a cozinha italiana inspira confiança, mesmo que suas origens sejam referendadas em um lugar distante. A domesticação a que se refere Goody (1989) seria exatamente esse processo em que as distâncias se afunilam e a cozinha se confunde com um produto local. Embora mantenha ainda vínculos que identificam a italianidade, essa se vê ameaçada pelos caminhos tomados pela cozinha italiana recente.

Por isso, o Slow Food não deixa de ser algo etnocêntrico, pois no fundo se inspirou em um modelo de cozinha que está muito associado à realidade dos países europeus e tinha como alvo principal os sistemas de restaurantes de comida rápida, em especial a rede McDonald's. As periferias absorveram a retórica e criaram suas próprias soluções, valorizando elementos locais que, no entanto, nem sempre possuem algum tipo de reconhecimento a nível nacional, como as cozinhas regionais da Itália ou França possuem.

Na verdade, entre nós, há uma falsa ideia de valorizar as cozinhas regionais como o conjunto que dará a base para uma cozinha nacional, mas muitas vezes o que se consegue é acentuar estereótipos ou valorizar o exótico, como tem se observado com as frutas amazônicas. Esse senso comum foi em parte resultado de uma apropriação particular das obras de Gilberto Freire e Luís da Câmara Cascudo, mas que vigoram no imaginário em torno das cozinhas e não deixou escapar a cozinha italiana praticada em São Paulo.

È interessante perceber que na classificação de cozinha italiana, a pizza foi ficando cada vez mais descolada como um prato independente desse conjunto e ganhou particularidades instigantes na cidade. Em primeiro lugar, é "a cara da cidade" emuma capital dita gastronômica. É preferencialmente consumida à noite e durante muitos anos foi o principal prato noturno consumido aos domingos, ao contrário de outros países que a consomem a qualquer hora do dia, inclusive na Itália.

Nas pizzarias ainda se encontram elementos formais de uma refeição, ali é possível reunir parentes ou amigos, come-se sentado em mesas com toalhas, pratos, talheres e o atendimento é feito por garçons. Quando se pede em casa muitas vezes essa formalidade é perdida e o consumo acaba sendo disperso pelos membros da família, cada qual com seu interesse: uns comem na cozinha, outros no sofá, outros na frente do computador, outros na televisão. No restaurante essa dispersão desaparece e a refeição adquire contornos mais próximos de uma refeição ideal ${ }^{271}$.

271 Murcott (1997) estudou amplamente essa noção e neste texto em especial evidencia os novos arranjos que permitem dar sentido aos consumos alimentares, uma hierarquia de eventos que falam sobre o que comer, quando, com quem, como. Sua discussão foi iniciada a partir de Douglas (1975) que analisou justamente essas composições a partir dos eventos alimentares. 
Nesse sentido, a cozinha italiana que falava sobre determinada trajetória e marcava a existência de certa comunidade italiana, mais imaginada que concreta, foi arremessada para as laterais da história quando aportam novos arranjos do comer fora, inclusive um diálogo renovado com a cozinha praticada na Itália. Comer macarronada aos domingos ainda pode ser um hábito paulistano observado em algumas casas, mas diluído à medida que surgem novas alternativas para realizar refeições fora de casa, especialmente quando lembramos que existe uma extensa oferta de restaurantes que facilitam o trabalho doméstico.

As cantinas eram o destino certeiro dos paulistanos que desejavam comer fora no fim-desemana, especialmente no almoço dos domingos, mas nem tanto pela comida que ofereciam, ao contrário do que pensam muitos interlocutores, mas porque reuniam os elementos para atender a uma sociabilidade específica daquele momento. Além disso, eram poucos restaurantes na cidade e quase todos, de uma forma ou outra, tinham algum vínculo com a cozinha italiana, mesmo que já domesticada. O próprio Mario Tatini dá uma pista sobre essa mudança ao contar que anos depois de estar localizado na Alameda Santos é que vieram outros restaurantes, como o Dinho's Place, churrascaria famosa nos anos 1980 e que também fazia movimento nos finsde-semana. Antes dele, somente o Bambi, restaurante de comida árabe que ficaria famoso pelo seu sorvete, o Choco L'amour ${ }^{272}$.

Nesse sentido, a cozinha italiana se globalizou, assim como outras cozinhas que acompanhavam os ditames globais, mas também novas articulações deram uma vivacidade distinta aos pratos italianos que começaram a conviver com novos sabores, como os da cozinha japonesa $^{273}$. Apesar de já estar presente na cidade, mas restrita à comunidade japonesa e seus bairros, especialmente a Liberdade, foi a cozinha que viajou com maior rapidez nos anos de globalização e foi o tipo de cozinha que inspirou a abertura do maior número de restaurantes na cidade de São Paulo na última década.

O que emerge nesse novo cenário é que as cozinhas foram perdendo seus vínculos étnicos e adquiriram novas relações em que o espaço e o tempo irão jogar novos papéis. A cidade cosmopolita, nesse sentido, é o ponto de confluência dessas cozinhas, que distanciadas de seu contexto original, oferecem por sua vez a proximidade com as culturas dos outros em uma espécie de museu gastronômico disponível nos restaurantes. Carregam sentidos completamente distintos daquelas cozinhas que vieram pelas mãos de imigrantes, uma versão local altamente disseminada e incorporada como natural e que agora dialoga com a cozinha italiana contemporânea servida em novos estabelecimentos.

272 Era uma sobremesa feita com sorvete de creme, coberto com calda de chocolate e coberto com uma farofa crocante, receita que dizem ser guardada a sete chaves.

273 Cwiertka $(2001,2003,2008)$ analisa a constituição de uma cozinha nacional japonesa, mas também sua interpretação fora do Japão, em especial o caso da Holanda. Também enfatizou o importante papel social dos restaurantes como espaços de trocas e intercâmbio entre sabores pouco comuns e sociedade local, em especial nos restaurantes que serviam marinheiros holandeses nos portos japoneses do século XVII. 
Diante desse quadro, talvez a pizza seja o prato da cozinha italiana que mais nitidamente marcou a gastronomia local desde que os imigrantes introduziram os sabores da Itália. Consumir pizza é algo tão rotineiro na cidade que a pizza paulista é famosa pelas qualidades, assim como sair para comer uma pizza é visto como um hábito tipicamente paulistano.

Em parte, a pizza correspondeu mais agilmente aos anseios das camadas médias que encontraram nos ambientes das pizzarias e de algumas cantinas que servem pizza, uma forma de manter vínculos com suas representações de uma refeição ideal. Acessível no preço, na forma de consumir e compartilhar, a pizza é um instrumento de comensalidade, quaisquer que seja o tipo de estabelecimento que a serve.

Tampouco é uma comida saudável, mas proporciona prazer: no sabor, na partilha, quando consumida. Uma versão contemporânea de um prato popular que estigmatizava quem o consumia, mas fundamentalmente social no sentido dos encontros que promove. A pizzaria não é normalmente um ambiente formal, mas é suficientemente organizada a ponto de permitir o convívio entre comensais, oferece uma refeição simples e rápida, fácil de ser pedida e consumida sem necessitar de algum conhecimento específico de etiqueta ${ }^{274}$. Sugere familiaridade em um mundo cujo excesso de opções acaba atordoando as escolhas ${ }^{275}$.

A pizza paulista, no entanto, está se deparando com uma nova questão, a sua legitimidade, pois segundo as novas leis italianas, uma pizza para ser chamada de napolitana deve seguir um roteiro de regras específicas, nesse caso a pizza local não poderia ser chamada de napolitana. É uma tentativa de levar um reconhecimento que não condiz com a realidade, apenas com interesses específicos de alguns grupos e ressaltar o pertencimento associado ao território.

Nesse caso, a pizza paulista, embora derivada da pizza napolitana e muitas vezes assim referida, seria apenas pizza, já que coberturas e combinações praticadas nas pizzarias da capital paulista soariam sacrílegas aos ouvidos italianos, invencionices de mau-gosto ${ }^{276}$. É uma discussão que envolve um conceito que recentemente foi levado à luz pelas cantinas do Bixiga e tangencialmente abordado na discussão do autêntico e tradicional, que emprestado de outras áreas é aplicado às cozinhas, a noção de patrimônio imaterial ou cultural.

A noção de patrimônio ganhou força justamente nesse contexto de incertezas culturais e, em especial, de identidades nem tão claras. Segundo Espeitx (2004), patrimônio é a construção ou

274 Ver a discussão iniciada com Elias $(1993,1994)$ e retomada por Finkelstein $(1989)$ e Warde \& Martens (2000).

275 O repertório de escolhas em torno da alimentação não é amplamente exercido por uma série de fatores que se baseiam desde lógicas de classificação do comestível e não comestível, como Sahlins (2003) e Douglas (1975) assinalaram, mas também com relação ao medo da incorporação, como Fischler (1990) discorreu e com relação ao risco, uma abordagem proporcionada por Giddens (1996).

276 É um movimento tão local e que se abre a disputas em múltiplas frentes que ninguém discute o fato de que na Itália nem mesmo há um entendimento do que é a verdadeira pizza. Em Roma, por exemplo, a ideia corrente é de que a pizza ali produzida tem sabor melhor devido à qualidade da água, no sul é devido à qualidade do queijo e assim por diante. 
invenção de uma ponte entre o passado e o futuro de uma sociedade, símbolo da transmissão de conhecimentos entre gerações e é em geral associado a identidades que falam sobre determinado grupo ou comunidade. De qualquer modo, apesar do que circula no senso comum, patrimônio é um conceito altamente mutável que depende do espaço, tempo e interesses de distintos grupos que também manipulam em seu favor sua definição.

Esse conceito é bastante abrangente, especialmente quando se toma da antropologia o conceito de cultura que, sem esgotar a questão por demais complexa, possibilitou englobar a arte, letras, técnicas, crenças, valores e tradições como materiais passíveis de serem transformados em patrimônio $^{277}$.

O Slow Food respondeu rapidamente a essa questão, mas não concentrou os movimentos que surgiram pelo mundo interessados em valorizar a cozinha local e, em alguma medida jogou luz à territorialidade e expôs questões delicadas em torno da autenticidade. A cozinha que viaja pelo mundo representa um determinado espaço e também uma determina cultura, portanto ao ser exposta em um restaurante estará enfatizando sua diferença e permitindo ser comparada. Mas se a cozinha exercida em sua origem adquire ares de espetáculo gastronômico, elas se tornam atrativos turísticos em restaurantes, bem como servem para mostrar o cosmopolitismo urbano ao ser mais uma diferença presente na cidade.

Desdobramento do discurso da homogeneização de sabores, essa retórica se revela como instrumento de preservação, embora plena de boas intenções, nem sempre os seus resultados condizem com as expectativas. Na verdade, as cozinhas distanciadas de suas práticas sociais e culturais as tornam apenas imitações vazias para preencher a ânsia por novas experiências que, em parte, são consideradas necessárias para ser um verdadeiro cosmopolita. Do outro lado, restaurantes reproduzem cenários e pratos que não falam dessas relações e mais se parecem a parques temáticos.

A coesão de determinadas cozinhas advêm justamente do que representam socialmente. Transformar uma cozinha em patrimônio é uma atitude positiva, mas seus desdobramentos lidam com as lógicas do mercado que se apropria do patrimônio para tornar um "produto vendável". O mesmo se passa com os restaurantes "de mais de 51 países", cujas cozinhas estão na capital gastronômica para alimentar sua imagem e se aproveitar desse imaginário para se consolidar na paisagem urbana. São lógicas muito distintas, uma verdadeiramente preocupada com a preservação e outra de cunho comercial que pretende transformar a comida em espetáculo do comestível, como bem pontuaram Contreras \& Arnaiz (2005).

277 A definição foi feita pela UNESCO que desde 1972 está debruçada sobre o tema quando instituiu a Convenção do Patrimônio Mundial, segundo Santos (2001). Foi também quando o conceito de universalidade passou a ser sistematicamente substituído pelo de representatividade, o que acabou expandindo em demasia a lista de bens que poderiam ser transformados em patrimônio, perdendo legitimidade e deixar de ser um espaço privilegiado para o debate do assunto. 
O espaço ainda é uma associação confortável com a comida, pois o território se associa a determinado grupo ou comunidade, bem como suas manifestações culturais. No entanto, uma determinada região é tão imaginária como as fronteiras que a delimitam, de modo que sua cozinha também flutua entre espaços de incerteza ${ }^{278}$.

É partindo dessa construção que muitos processos querem reconhecer as cozinhas regionais como patrimônio, tendo como consequência uma dissolução de vínculos mais estreitos com o social. Dessa forma, o espaço passa a ser privilegiado e as cozinhas regionais são tomadas como um conjunto de receitas que serão destinadas à exploração comercial. Justifica, inclusive, a razão pela qual as cozinhas regionais brasileiras que se pretendem reunir para formar uma cozinha nacional não tenham apelo como um conjunto reconhecido a não ser na retórica turística. Faltalhes substância social que lhes dê o estofo suficiente para considerá-las a base de um emblema nacional, não representam uma identidade regional e surgem como reproduções esvaziadas de discursos que não condizem com a realidade, mas se interessam em criar uma imagem destinada ao incremento turístico.

Essa perspectiva deriva de uma associação comumente feita entre território, grupo e cultura, já mencionada ao longo do trabalho e que se reproduz no discurso em torno do patrimônio. $\mathrm{Na}$ verdade, é muito mais um processo de seleção, tal como ocorre com a memória, do que um rastreamento histórico, mesmo porque uma cozinha vinda de fora transformada em patrimônio da cidade seria por si uma contradição, especialmente quando se pensa a tradição como pureza. A questão não aponta essa ausência, bem como não desenvolve uma reflexão do encontro cultural promovido pela imigração que acaba sendo percebida quase como uma contribuição mítica nas narrativas dos entrevistados.

$\mathrm{Na}$ verdade, não há uma abordagem profunda em nenhum momento sobre a cozinha que persiste ser estudada sob um olhar folclórico. Definida como um elenco de comidas típicas encontradas em grupos ou comunidades associadas a festas ou encontros de origem religiosa, a noção de cozinha regional foi foco de vários debates ${ }^{279}$.

Em um crescente descolamento de sua vida social, essas cozinhas são tomadas como uma série de receitas e ingredientes encontrados em determinadas localidades, sem levar em conta elementos temporais e sua reconstituição em novos contextos, em geral, estimulados pelos diversos fluxos imigratórios e pelo aumento acentuado de circulação de pessoas pelo mundo.

Uma receita pode viajar e ser reproduzida fora de suas origens, como inclusive foi o caso da cozinha italiana. Mas, certamente os arranjos locais tiveram influências surpreendentes e que se viram diante de novos diálogos estimulados pela circulação de informações, pessoas

\section{Consultar Bell \& Valentine (Op.Cit.) e Laferté (Op.Cit.).}

279 Revel (1996), Appadurai (1988). Ver também Katz (2008). Essa questão também faz parte das discussões empreendidas pelo Grupo Alimentação e Cultura, reunido quinzenalmente no Centro de Excelência em Turismo da Universidade de Brasília, sob responsabilidade da Profa. Dra. Ellen Woortmann. 
de maneira singular, especialmente a partir da Internet. Rapidamente, surgem restaurantes especializados em distintas cozinhas e, talvez, os primeiros contatos do cosmopolita com uma cozinha distinta da sua, cuja representação irá construir um referencial para futuros julgamentos quer em viagens ou em restaurantes.

E esse imaginário foi transportado para as grandes cidades, os restaurantes serão os lugares que reuniram pessoas importantes e sintetizaram forças locais e globais ${ }^{280}$, em uma espécie de recuperação territorial de cozinhas regionais por meio do restaurante. E os comensais cosmopolitas irão desfrutar desses sabores, no entanto, o restaurante poderá ter um papel de preservação, embora não muito claro, mas presente no imaginário, especialmente quando há algum chef envolvido.

O distanciamento da cozinha de seus atores, tanto produtores como consumidores, a transforma em uma lista de receitas e valoriza uma noção estreita da cozinha do que representa. Nesse caso, certos produtos, técnicas e conhecimentos são descartados para criar um conjunto coerente cujo objetivo é ser "comercializável" pelo restaurante e palatável ao público que o frequenta. A temporalidade também adquire novos sentidos quando inserida nessa lógica, como ficou evidente nas articulações de Afonso Roperto e a revalorização de sua cantina como "patrimônio da cidade".

Falar em patrimônio, segundo Afonso Roperto, é uma forma de valorizar "anos de trabalho", como também sabores que devem ser compartilhados com outros comensais. A comida da cantina perdeu seu contato com as práticas familiares que a originaram, embora guarde este imaginário como um bem precioso para criar em torno de si o conceito de patrimônio cultural, no qual memória e família constituem parte de sua base, um encontro fortuito para narrativas não históricas. E com esse instrumento em mãos se lançam na busca de novos comensais, os turistas em uma tentativa desesperada de reverter uma curva descendente.

A ideia de constituir o bairro do Bixiga como patrimônio cultural da cidade de São Paulo partiu dos próprios moradores e empresários, com o intuito de estimular a visita de turistas, já que os comensais locais escasseavam assustados com a violência e com a suposta falta de qualidade das refeições que eram servidas nas cantinas. Nesse caso, a temporalidade, ou tradição, foi resgatada com um sentido positivo e trouxe um novo olhar para a comida, embora nem todos os proprietários de cantinas concordassem com essa estratégia.

Entretanto, é curioso notar que apesar de ser uma cozinha vinda de fora, conquistou um espaço diferenciado na cidade, com tamanha popularidade que é considerada patrimônio cultural, uma tradução viva da contribuição da imigração para a capital paulista, herança dos primeiros habitantes que ali se instalaram e deixaram seu legado para ser degustado nos espaços tradicionais. De certo modo há preservação, mas de elementos que foram julgados interessantes

280 Consultar a Zukin (1998 e 2002) e também Ferguson \& Zukin (1995). 
por determinados agentes e instituições. Corre o risco somente de ser mais uma cozinha típica, uma espécie de fotografia para ser consumida, digerida e falada ${ }^{281}$.

$\mathrm{O}$ apego à tradição e atitude reticente à mudança se justifica a partir desse momento como forma de preservação de uma memória que foi selecionada e introduzida em uma nova gramática. Se em outro momento, seguir receitas "com mais de cem anos" foi uma maneira de justificar a divisão entre restaurantes mais refinados de outros menos, é fato que na capital gastronômica houve uma fusão das memórias que acabaram aglutinando as cantinas e os restaurantes de comida italiana tradicionais em uma mesma categoria, a de antiquados ou pior, decadentes.

Afonso Roperto observou, ainda, que possivelmente as próximas gerações nem saberão o que é comida de cantina, ressaltando a importância de conduzir a consolidação do Bixiga como patrimônio, assim como suas cantinas, "as pessoas vão esquecer da gente se não fizermos nada". Sua estratégia é preservar a memória para que no futuro as pessoas possam saber que a cozinha italiana teve uma importante contribuição na capital paulista e uma forma específica de afirmar a presença italiana.

É uma cozinha que não quer perder a importância dos italianos, de valores associados à família e ao trabalho, mesmo que os novos consumidores dessa cozinha venham de outras cidades, do interior do estado e do País. Afonso diz que seu restaurante proporciona uma "experiência cultural", pois estão consumindo história de São Paulo e não uma comida envelhecida, como inclusive muitos jornais e revistas definem a comida de cantina atual.

Para os restaurantes da velha guarda se trata de não esquecer sua contribuição e sua trajetória de imigrante italiano na cidade, realçando aquilo que se considera importante, além de resgatar comensais para seus estabelecimentos. Para os novos restaurantes, a imagem é de uma cozinha italiana mais próxima daquilo que se faz na Itália contemporânea, embora não deixe também de ser uma reprodução.

É uma oscilação entre os mais conservadores que temem perder elementos de sua identidade se interferir em demasia em seu restaurante e os inovadores que introduzem novos sabores, pratos e ambientes. Os frequentadores, de seu lado, incorporam novos sabores, lidam com os antigos, mas não procuram somente satisfação na comida. A refeição fora de casa entrelaça fios que perpassam pela comodidade, atendimento, motivação e em função de atender a essas expectativas, o evento será percebido de modo positivo ou negativo, estendendo-se à comida, dependendo a posição que ocupa em uma estrutura mais ampla que incorpora distintas refeições.

Alguns interlocutores percebem essas nuances, mas nem sempre agem no sentido de atender aos comensais, pois há um apego à ideia de tradição. Adolfo, do Jardin di Napoli não cogita

281 Na realidade, Falk (1994) oferece uma abordagem instigante sobre esse assunto, lembrando que a comida não serve nem mesmo para pensar, pois agora ela é para ser falada. Falar sobre comida passou a ser uma forma de distinção mais usual até do que consumi-la. É um tema que merece um desenvolvimento posterior mais amplo. 
em fazer qualquer mudança, especialmente no principal prato da casa, o polpetone, "a maioria dos clientes vêm aqui e quer comer o polpetone, como é que vou mudar?". A perna de cabrito assada é também um item que não sai do cardápio, lembrou Afonso Roperto, ou o Capeletti à romanesca que Giovanni Bruno inventou nos idos dos anos 1960 e serve até hoje. O mesmo se dá com as pizzas: margherita, mussarela e calabresa permanecem firmes nas opções, embora estas não tenham tanta dificuldade em introduzir novos sabores, pois não alteram a substância, por assim dizer, do produto final.

Restaurantes da velha guarda procuram ser vistos como tradicionais, graças ao tempo em que atuam, mas a capital gastronômica nem sempre assim os reconhece, em muitas ocasiões são tidos como antiquados e típicos, ou seja, sua comida e seu ambiente já tiveram seu apogeu, agora se parecem a peças de museu. Nesse registro emerge a ideia de patrimônio cultural, menos preocupado em preservar e mais como uma forma de proporcionar diversão. Patrimônio seria uma forma de representar uma identidade coletiva, mas o uso dessa noção atende a outros fins, inclusive comerciais.

$\mathrm{Na}$ verdade, a tradição, ou certa tradição, permitiu transformar as cantinas do Bixiga em patrimônio, no entanto, a comida estará em um novo contexto. O comensal que se dirige a uma cantina nesse bairro em geral é de fora da cidade e deseja conhecer um aspecto de sua história e cultura, segundo a retórica apropriada pelo interlocutor que tende a valoriza o patrimônio como forma de incentivo ao turismo. Misturam-se temporalidades e localidades para conceder autenticidade ao restaurante e sua trajetória.

As cantinas tentam ser vistas como tradicionais, ou pelo menos, típicas já que exercem uma cozinha que se parece mais a uma fotografia no tempo, embora seus descendentes tentem o contrário. E tiveram melhor sorte que os restaurantes requintados da velha guarda, pois estes não nasceram sob o signo da comida doméstica, tampouco conseguiram associar de modo coerente valores ao que oferecia ao longo do tempo. Considerados modernos em seu momento e servindo alta gastronomia, foram penalizados por não acompanhar as mudanças que aconteceram na Itália.

A cozinha italiana, como se vê, pode ser popular na cidade, bem aceita, mas revela distintos planos de italianidade que dialogam entre si, frente à sociedade local e com sua origem. Ser italiano em graus distintos dependerá como se interpreta pertencer a uma nação ou herdar um legado italiano, como Adolfo com seu pesado sotaque surpreendeu ao dizer que ele e sua mãe são brasileiros, "mas sou mais italiano que muito italiano". Seu sentimento de ser italiano estava associado ao que ele concebe o que é italiano: ser trabalhador, respeitar a família, manter a tradição, nesse caso, referindo-se à comida.

E se as identidades regionais desapareceram à medida que os italianos eram englobados à sociedade local, classificados como imigrantes logo que os primeiros fluxos aportaram, elas 
reaparecem na cozinha da capital gastronômica, embora sem uma relação direta entre italianos e restaurantes. Esse ponto parece ser o grande diferencial entre os descendentes de italianos que possuem restaurantes e os restaurantes sem italianos, apesar da cozinha que praticam. A cozinha italiana contemporânea praticada em alguns estabelecimentos seria então uma imitação, uma cópia, faltando-lhe tempo e valores. Em suma, é uma disputa de autenticidade dispostas sob perspectivas distintas.

A cidade se aproveita dessa disputa e se reafirma como capital gastronômica, pois oferece diferentes opções de uma mesma cozinha, bem como desenvolveu uma apropriação local que a faz reconhecida ante outras cidades, a pizza. Não se trata de inventar novos pratos, como vários interlocutores afirmaram, mas adaptar e usar a criatividade para conseguir um resultado que satisfatório e disso resultou a cozinha de cantina que hoje circula entre uma imagem negativa na capital gastronômica, e outra positiva fora dela.

A cozinha italiana praticada na cidade revelou então novas articulações. O passado étnico persiste, mas dialoga com questões locais e globais, fala de descendência, de integração, de diálogo com a Itália. Assim, tanto a comida italiana como as pizzas evidenciam um caráter polissêmico próprio da cidade cosmopolita, mas não deixam de pensar sobre a italianidade. Mesmo já engolidos pela sociedade local, tentam preservar elementos que os diferenciam com relação a outros grupos locais e custam a lidar com o fato de serem vistos como brasileiros na Itália.

Não chega a ser um conflito de gerações, mas sem dúvida há uma questão importante nessas relações entre avós, pais, filhos e netos, que revelam negociações, sobretudo nas inovações. Esses obstáculos nem sempre são superados e impedem assumir posições mais ousadas frente à realidade colocada. Não se trata somente de adaptação à globalização e ao uso do espaço urbano, pois isto também possui implicações nas vidas cotidianas que ainda reverenciam uma memória.

A exploração dessa nova a italianidade remete a uma nova concepção do étnico. A dicotomia observada entre erudito e popular, apontada por Pereira (2003) permanece de alguma forma latente, mas ser italiano hoje é antes de tudo um trabalho da memória dos descendentes, já que são poucos os que nasceram na Itália e ainda estão vivos. As linguagens escolhidas para ressaltar identidades irão se inspirar na memória, bem como nas articulações entre tempo e espaço que convergem para a cozinha.

Mas não se trata somente de mudanças nas práticas alimentares é fato que aconteceram e gostos foram moldados a partir de outras bases. O que chama a atenção de maneira mais evidente é um sentimento em que se mistura certa melancolia pela certeza de que essas mudanças vieram para ficar e o restaurante não será mais o mesmo dos "tempos áureos". São os novos tempos já presentes e cada vez mais exigindo que a velha guarda saia de cena, apesar de seus esforços 
para preservar a memória de uma trajetória que ainda alimenta sua identidade e custa a lidar com a inversão de um processo que durante anos foi seu. A Itália recebe brasileiros e manda sua cozinha global para colocar em xeque uma experiência que transcendeu oceanos. 



\section{CONSIDERAÇÕES FINAIS}

Foi de fato um trabalho prazeroso de realizar, comida é um assunto pelo qual tenho especial apreço, pois representa um espaço importante de minha própria trajetória e que muitas vezes me causou sentimentos de deslocamento, frisando um caráter transitório do lugar em que estamos. Não foi por acaso que me identifiquei com as palavras de Regueiro (1995, Apud OLIVEIRA, 2000), uruguaia como eu, vivendo nos Estados Unidos e sentido as virtudes e desvios de ser um "estrangeiro". Na verdade, é preciso considerar que os lugares que hospedam os imigrantes também afetam a forma pela qual os imigrantes irão construir suas representações em torno dessa experiência e, com isso, também a forma que sua comida irá expressar seus reconhecimentos e aversões.

O deslocamento (desplazamiento) pode ter sido, sem dúvida, um sentimento pelo qual os primeiros imigrantes passaram, embora amenizado nas memórias dos interlocutores, uma vez que desfrutam de um lugar muito mais confortável na capital paulista.

\footnotetext{
Nem identidade étnica nem a nacional podem ser o que eram no antigo país: o conceito de ser uruguaio carece de sentido nos Estados Unidos, e no Uruguai se assume. E o conceito de identidade étnica carece de sentido no Uruguai, e é vital nos Estados Unidos do final do século XX. Tanto a identidade étnica com a nacional são constructos com um propósito: no caso da identidade nacional, a coesão de um país por meio da narração de sua cultura e de sua história, e no caso da identidade étnica, a narração a partir da margem da história e da cultura daqueles que precisamente são excluídos da narrativa da primeira. (REGUEIRO ÉLAN, apud OLIVEIRA, 1995, pp 321-322)
}

E não vejo muita diferença com a trajetória empreendida pelos imigrantes italianos, hoje já desfrutando de uma situação em que conseguiram se inserir na história oficial, longe das margens, sendo parte de uma narrativa oficial e local. O conceito de identidade étnica teve um papel central, pelo menos a princípio, permitindo que pessoas sem compartilhar elementos em comum encontrassem um fio que as unisse. De fato, a consciência italiana somente foi moldada a partir das interações com a sociedade local, pois até então os reconhecimentos eram basicamente regionais.

Tanto na vida do grupo, mesmo que mais imaginado do que de fato constituído, como em sua comida, a tônica era operar a inclusão e a exclusão, pois logo que chegaram os imigrantes eram considerados abjetos pela sociedade que os hospedou. Às margens de uma narrativa oficial, conseguiram forças para estar no centro, valorizados como aqueles que trouxeram o desenvolvimento para a cidade. Isso não deixa de ser curioso, pois foi essa justificativa dada na época para atrair os italianos, embora quando aqui instalados tivessem encontrado uma recepção muito menos calorosa do que imaginaram. Tidos como sujos, arruaceiros, bêbados 
foram décadas passadas para inverter essa posição, tomando do repertório urbano já existente uma imagem para si. A comida acompanhou esse compasso.

Imigrantes analfabetos concentrados em bairros operários estabeleceram os primeiros vínculos entre si com base em uma solidariedade étnica, de vizinhança. A comida imediatamente se fez presente como um indicador de quem era esse grupo, reproduzindo a partir de conhecimentos tradicionais e domésticos, produtos que serviram para demarcar um pertencimento étnico. Pão, macarrão e pizza começaram a circular, sobretudo nas vias de um comércio informal e também étnico que, apesar das diferenças regionais, basicamente eram presenças constantes na alimentação desses imigrantes, salvo a pizza, pois esta só ficou conhecida fora do sul da Itália em meados do século XX.

Naquele momento, ninguém comia fora, mas servir uma sopa ou macarrão aos paisani representou uma forma de engordar orçamentos esqueléticos entre famílias de origem italiana. Sem qualquer proximidade com os restaurantes contemporâneos, as cantinas como ficaram conhecidas, eram espaços que mesclavam a casa e a rua. A comida servida era a mesma da família, quem atendia era o marido que armava mesas improvisadas nas calçadas para atender aos conhecidos.

A comida, pelo que foi ouvido, era simples e até mesmo monótona, embora fossem introduzidos alguns ingredientes, sobretudo verduras e algumas frutas. Mas, foi uma comida que permaneceu circunscrita aos bairros onde nasceu, ganhou visibilidade anos depois na sociedade local quando a cozinha italiana se instala em restaurantes no centro. Atraíram comensais locais, muitos membros das novas classes médias urbanas e especialmente aqueles ligados às artes, cultura, empresários e dirigentes de empresas.

Em outro plano, os descendentes de italianos que nasceram em bairros como Brás, Bixiga, Belenzinho, Bom Retiro etc. saíam para fixar residência em outras regiões e eventualmente voltavam para saborear a comida das mammas, sobretudo domingos na hora do almoço. Essa dinâmica ficou mais evidente nos anos 1960, trazendo prosperidade para as cantinas nesse período e na década seguinte. A comida transbordava as fronteiras étnicas, bem como os italianos conquistavam um espaço mais confortável na cidade.

Era também um momento em que a cidade presenciava grande efervescência cultural, mas também mesclava referências entre imigrantes. Enfrentamentos entre italianos que vieram nas primeiras levas, a velha guarda, descendentes e novos italianos criavam animosidades variadas. Entre os descendentes existia a busca pelo reconhecimento, de maneira que muitos não seguiram o caminho de seus pais, mesmo porque foram incentivados para estudar e conseguiram trabalhos melhores que seus pais e avôs. As novas levas se consideravam mais preparadas que os imigrantes mais antigos e estes consideravam os novos como "preguiçosos".

Nessa época, meados dos anos 1950, a maioria dos italianos da região norte chegou à cidade: em geral se viam superiores aos do sul, sobretudo pelo avanço econômico da região. 
Possuíam melhor preparo intelectual, tinham uma profissão e alguns já tinham um emprego já prometido.

Representavam também diferentes italianidades, pois de um lado era o esforço de enfrentar uma realidade sem qualquer amparo, de outro dispor de algum tipo de conhecimento que facilitaria a inserção no local. A disputa pelas ocupações de maior prestígio era agora entre descendentes da velha guarda e italianos vindos após o fim da $2^{\underline{a}}$ Guerra.

Nesse caso, a cozinha italiana em restaurantes se dividiu entre cantinas e restaurantes requintados, lendo-se também as novas articulações em que italianos se viam entremeados. Além de um fluxo distinto vindo no pós-guerra, que trouxe um status proveniente de diferenças de classe, estavam as novas gerações ${ }^{282}$. Além disso, existia uma ruptura ainda maior: quem produzia a comida nesses estabelecimentos.

As cantinas associadas, aos primeiros tempos, à cozinha doméstica poderão ou não contar com as mulheres na cozinha, mas sua comida será bem menos refinada quando comparada aos outros estabelecimentos que servem comida dita do norte, ocupando um lugar completamente diferente de seus antecessores, embora ambos afirmassem servir cozinha italiana. As identidades dos imigrantes que eram marcadas pelos regionalismos entre oriundos do sul seriam diluídas quando interagissem com italianos do norte, compondo uma oposição maior entre norte e sul, ricos e pobres, esclarecidos e analfabetos. Cada qual valorizava coisas diferentes: os antigos valorizavam o trabalho, especialmente quando foram muito pobres e outros, a distinção, quando a família já desfrutava de uma posição melhor.

A comida de restaurantes representou essa ruptura, embora mais que paisagens opostas entre norte e sul, ela na verdade conscientizou a existência de diferentes trajetórias entre italianos. A cozinha irá construir laços artificiais a partir de um reconhecimento imaginário e concretizados na comida, incluindo ou excluindo. A comida italiana do norte não foi destinada aos imigrantes e seus descendentes, mas às novas classes privilegiadas na cidade.

Nos anos de Capital Mundial da Gastronomia esses restaurantes irão sofrer o impacto das transformações mais gerais que afetaram as práticas alimentares. Comer fora de casa torna-se uma prática corriqueira e os restaurantes surgem para atender a essas novas sociabilidades. Somase a isso o fato de que, ao alimentar a ideia de uma capital gastronômica, camadas privilegiadas procuram cada vez agradar seu paladar com sabores diferenciados e há uma profusão de novas cozinhas na cidade, inclusive uma cozinha associada à Itália, dita "mediterrânea".

E se antes existia uma divisão entre cozinha do norte e do sul, agora se transformou entre cozinha antiquada e contemporânea, entre o local e o cosmopolita. As cantinas e os restaurantes requintados dos anos 1950 e 1960 são a lembrança viva da imigração, mas também de sua

282 Para uma discussão sobre este tema, consultar Kalcik (1984). 
inércia frente às mudanças. Buscam pela tradição se reafirmar, bem como seus proprietários sentem o peso dessa decisão ao se deparar com novas linguagens da cozinha italiana.

É também quando se multiplicam os espaços para comer. Restaurantes especializados em comida italiana não são os únicos a servir seus pratos, self-service (bufê ou quilo), comida rápida, bistrôs, lanchonetes oferecem a oportunidade de saborear comida italiana. Explodem as opções e crescem as dificuldades em manter um trabalho que teve sentido ante um determinado ritmo urbano em que existiam poucos restaurantes, comer fora era um evento especial e a globalização ainda não tinha escancarado as portas das informações.

É o grande momento da pizza. Congrega ao redor da mesa, pode ser consumida fora ou em casa, não afeta o orçamento e pode ser preparada com diversos ingredientes agradando distintos paladares. De massa fina ou massa grossa, a pizza se transforma em um prato que irá definir a "cara de São Paulo" e, apesar de suas origens serem de fora, o fato de ter vindo pelas mãos de italianos parece lhe atribuir maior respeitabilidade. A pizza paulista é " $a$ melhor do Brasil", pois teve o fortuito encontro de italianos e particularidades que a fizeram adquirir proeminência nacional. É a italianidade globalizada com sotaque local, os italianos trouxeram e a aperfeiçoaram, realçando mais uma vez sua habilidade para o progresso.

No discurso hegemônico da Capital Mundial da Gastronomia esse reconhecimento parece não existir, ele corre em paralelo, uma vez que a pizza é popular. O intuito é se mostrar distinto ao oferecer e desfrutar sabores de vários países, uma imagem que condiz com o imaginário das classes favorecidas e cosmopolitas. A pizza pode ser sofisticada, mas sem dúvida é popular, pois transita entre gerações, classes, gêneros, eventos alimentares de motivações variadas.

A identidade, ou melhor, as identidades italianas se diluíram da mesma forma que sua cozinha, embora não deixe de enunciar sua participação na construção da metrópole cosmopolita e valorize sua trajetória como um aspecto natural da cidade. Os descendentes de italianos, ou simplesmente italianos como se definem, trouxeram seus sabores, os disseminaram, e alguns restaurantes mais antigos não querem se perder no cenário da gastronomia cosmopolita da cidade. Querem que seus sabores e trabalho sejam lembrados, embora se vejam ameaçados sob novos fluxos que transformaram o comer contemporâneo em uma panacéia de escolhas. 


\section{REFERÊNCIAS}

ABDALA, Mônica. Mesas de Minas: as famílias vão ao self-service. Tese (Doutorado em Sociologia) - Departamento de Sociologia da Faculdade de Filosofia, Letras e Ciências Humanas. São Paulo: Universidade de São Paulo, 2003.

ABDALA, Mônica. Self-services: espaços de uma nova cena familiar. Caderno Espaço Feminino: Uberlândia, vol. 6, n.6, jan/julho 1999.

ABDALA, Mônica. Receita de mineiridade. Uberlândia: Edufu, 1997.

ALEXANDER, Davi. The Geography of Italian Pasta. In: Professional Geographer, número 52 (3), 2000, p. 553-566.

ALGRANTI, Leila M. Famílias e Vida doméstica. In: NOVAIS, Fernando (coord.) \& SOUZA, Laura Mello (org). História da vida privada no Brasil. São Paulo: Cia. Das Letras, vol.1, 1997.

ALFINO, Mark; CAPUTO, John \& WYNIARD, Robin (eds). McDonaldization revisited. Westport: Praeger, 1998.

ALFONSO, Maria Jose Pastor. El patrimonio cultural como opcion turistica. Porto Alegre: Horizontes Antropológicos, v.9, número 20, out. 2003.

ALVAREZ, Marcelo \& MEDINA, Xavier (Eds.) Identidades en el plato. El patrimonio cultural alimentario entre Europa y America. Barcelona: Icaria, 2008.

ALVIM, Zuleika M.F. Brava Gente! São Paulo: Editora Brasiliense, 1986.

ALVIM, Zuleika M.F. O Brasil Italiano (1880-1920). In: FAUSTO, Boris (org.). Fazer a América. São Paulo: Edusp, 2000.

AMARAL, Rita de Cássia de Mello Peixoto. Festa à brasileira: significados do festejar no país que "não é sério". Tese (Doutorado em Antropologia) - Departamento de Antropologia da Faculdade de Filosofia, Letras e Ciências Humanas. São Paulo: Universidade de São Paulo, 1998.

AMERICANO, Jorge. São Paulo nesse tempo (1915-1935). São Paulo: Edições Melhoramentos, 1962.

ANDERSON, Benedict. Comunidades Imaginadas. Lisboa: Edições 70, 1991.

APPADURAI, Arjun. Disjunção e diferença na economia cultural global. In: FEATHERSTONE, Mike (org.). Petrópolis: Editora Vozes, 1999.

APPADURAI, Arjun. Modernity at large. Minneapolis: University of Minesotta Press, 1996.

APPADURAI, Arjun. How to make a national cuisine: cookbooks in contemporary India. Comparative Studies in Society and History, 30(I): 3-24, 1988.

APPADURAI, Arjun. The social life of things. Cambridge: Cambridge University Press [1986], 2003. 
APPADURAI, Arjun. Gastro-politics in hindu south Asia. American Ethnologist, vol. 8, number 3, August, 1981.

ARAUJO, José Renato de Campos. Migna Terra: migrantes italianos e fascismo na cidade de São Paulo (1922-1935). In: VIII Congresso Luso-Afro-Brasileiro, setembro de 2004, Rio de Janeiro.

ARAÚJO, Sílvia Maria Pereira de \& CARDOSO, Alcina Maria de Lara. Italianos no Brasil ou a Pátria recriada. In: BONI, Luís A. de (org.) A presença italiana no Brasil: Quem somos! Itália viva! Um futuro que vem de longe. Porto Alegre/Torino: Escola Superior de Teologia/ Fondazione Giovanni Agnelli, volume I, 1987.

ARCHETTI, Eduardo. "Hibridación, pertenencia, localidad en la construcción de una cocina nacional”. Trabajo y Sociedad, Barcelona, número 2, vol. II, março-julho, 2000.

ARIÈS, Paul. La fin des mangeurs. Paris: Desclée de Brouwer, 1997.

ARNAIZ, Mabel Gracia. Somos lo que comemos. Barcelona: Ariel Antropologia, 2002.

ARRUDA, Maria Arminda. Metrópole e Cultura. Bauru: Edusc, 2001.

ARRUDA, Maria Arminda. Empreendedores culturais imigrantes em São Paulo de 1950. Tempo Social - Revista de Sociologia da USP: São Paulo, v.17, número 1, 2005.

ARIÉS, Paul. La fin des mangeurs. Paris : Desclée de Brouwer, 1997.

ASHKENAZI, Michael \& JACOB, Jeanne. The essence of Japanese Cuisine. Surrey: Curzon Press, 2000.

ASSMANN, Jan (tradução para o ingles de CZAPLICKA, John). Memory and Cultural Identity. New German Critique, no. 65, pp 125-133, Spring-Summer, 1995.

AUGÉ, Marc. Não-Lugares. São Paulo: Papirus, 1994.

AYMARD, Maurice; GRIGNON, Claude \& SABBAN, Françoise. "A la recherche du temps social". In: AYMARD, Maurice; GRIGNON, Claude \& SABBAN, Françoise. Les temps de manger. Alimentation, emploi du temps et rythmes sociaux. Paris : Editions de la Maison des sciences de l'Homme: Institut national de la recherche agronomique, 1993.

BAILY, Samuel L. Nova York: Cornell University Press, 1999.

BAKHTIN, Mikhail. A cultura popular na Idade Média e no Renascimento: o contexto de François Rabelais. São Paulo: Hucitec, 1987.

BARRETO, Teresa Cristófani. A receita de Mário Tatini. São Paulo: Iluminuras, 2004.

BASSANEZI, Maria Silvia C. Beozzo. Família e Imigração Internacional no Brasil do passado. Estudos de História: São Paulo, UNESP, volume 6, número 2, 1999, p. 289-315.

BEARDSWORTH, Alan. Trans- science and moral panics: Understanding food scares. British Food Journal, 92, 5, 1990.

BEARDSWORTH, Alan \& KEIL, Teresa. The vegetarian option: varieties, conversions, motives and careers. The Sociological Review, Vol.40, no.2, maio 1992. 
BEARDSWORTH, Alan. The management of food ambivalence: Erosion and Reconstruction? In: MAURER, D. \& SOBAL, J. Eating agendas: Food and nutrition as social problems. New York: Aldine de Gruyter, 1995.

BEARDSWORTH, Alan \& KEIL, Teresa. Sociology on the menu. New York: Routledge, 1997.

BELASCO, Warren \& SCRANTON, Philip (ed.). Food nations:selling taste in consumer societies. New York: Routledge, 2002.

BELL, David \& VALENTINE, Gill. Cosnuming Geographies. London: Routledge, 1997.

BERMAN, Marshall. Tudo que é sólido desmancha no ar. São Paulo: Cia. Das Letras, 1999.

BERNASCONI, Alicia. Imigrantes Italianos na Argentina (1880-1930): uma aproximação. In:

FAUSTO, Boris (org.). Fazer a América. São Paulo: Edusp, 2000.

BERTONHA, João Fábio. O Brasil, os imigrantes italianos e a política externa fascista, 19221943. Revista Brasileira de Política Internacional, número 40 (2), 1997, pp 106 a 130.

BERTONHA, João Fábio. Conde Francesco Matarazzo e o ser italiano no Brasil: enfoque biográfico na pesquisa sobre a colonização italiana em São Paulo. Revista Eletrônica de História do Brasil: Juiz de Fora: UFFJ, v.4, no.1, pp.15-25, jan/jun, 2000.

BERTONHA, João Fábio. Entre Mussolini e Plínio Salgado: O Fascismo italiano, o integralismo e o problema dos descendentes italianos no Brasil. Revista Brasileira de História: São Paulo, v. 21, número 40, pp. 85-105, 2001.

BERTONHA, João Fábio. Os italianos. São Paulo: Editora Contexto, 2005.

BERTRAN, Miriam; ARROYO, Pedro. Antropologia y nutrición. Ciudad de Mexico: Fundación Mexicana para la Salud (Fondo Nestlé para la Nutrición), 2006.

BESSIÈRE, Jacinthe. Valorisation du patrimoine gastronomique et dynamiques de développement territorial. Le haut plateau de l'Aubrac, le pays de Roquefort el le Périgord noir. Ruralia [en ligne], mis en ligne le 25 janvier 2005, reference du 18 mai 2006, http://ruralia. revues.org/document154.html.

BOLLANSKI, Luc. Usos fracos e usos intensos do habitus. In: ENCREVÉ, Pierre \& LAGRAVE, Rose-Marie. Trabalhar com Bourdieu. Rio de Janeiro: Bertrand, 2005.

BONI, Luís A. de (org.) A presença italiana no Brasil: Quem somos! Itália viva! Um futuro que vem de longe. Porto Alegre/Torino, Escola Superior de Teologia/Fondazione Giovanni Agnelli, volume I, 1987.

BONI, Luís A. de (org.) A presença italiana no Brasil. Porto Alegre/Torino: Escola Superior de Teologia/Fondazione Giovanni Agnelli, volume II, 1990.

BONI, Luís A. de (org.) A presença italiana no Brasil. Porto Alegre/Torino: Escola Superior de Teologia/Fondazione Giovanni Agnelli, volume III, 1996.

BONIN, Anamaria e ROLIM, Maria do Carmo. Hábitos alimentares: tradição e inovação. Boletim de Antropologia: Curitiba, v.4, no. 1, junho, 1991. 
BOSI, Ecléa. Memória Sociedade. São Paulo: Companhia das Letras, 1994.

BOURDIEU, Pierre. La distinction. Paris : Éditions Gallimard, 1979.

BOURDIEU, Pierre. A economia das trocas simbólicas. São Paulo: Editora Perspectiva, 1998. BOURDIEU, Pierre. Razões Práticas. Campinas: Papirus, 1996.

BOURDIEU, Pierre. O poder simbólico. Rio de Janeiro: Bertrand Brasil, 1998.

BOURDIEU, Pierre \& PASSERON, Jean-Claude. Le sens commun. Paris : Les Editions Minuit, 1999.

BRANCO, Juçara de Souza Castello. Mulheres Italianas e imaginário coletivo. Resenha crtítica. Revista Estudos Feministas: Florianopólis, 11(2) : julho/dezembro, pp. 661-680, 2003.

BRAUDEL, Fernand. Civilização material, economia e capitalismo, séculos XV-XVIII. São Paulo: Martins Fontes, 1997.

BRILLAT-SAVARIN. A fisiologia do gosto. São Paulo: Cia . das Letras, 1995.

BROWN, Linda Keller; MUSSELL, Kay. Ethnic and regional Foodways in the United States. Knoxville: Kentrucky University Press, 1984.

BRUNO, Ernani Silva. História e tradições da cidade de São Paulo. São Paulo: Hucitec, volumes 2, 1984.

BRUNO, Ernani Silva. História e tradições da cidade de São Paulo. São Paulo: Hucitec, volumes 3, 1954.

BRUNO, Giovanni. ...Aos nossos momentos. Texto de Ângelo Iacocca, São Paulo: Depoimento Editorial, 1994.

BUENO, Eduardo. Os nascimentos de São Paulo. Rio de Janeiro: Ediouro, 2004.

BUONASSI, Rosário. Pizza. Buffalo: FireFly Books, 2000.

BUTLER, Judith. Fundamentos Contingentes: O feminismo e a questão do 'pós-modernismo'. Cadernos Pagu: Campinas, (11), pp. 11-42, 1988.

BUTLER, Judith. Corpos que pesam: sobre os limites discursivos do 'sexo'. In: LOURO, Guacira Lopes (org.). O corpo educado. Belo Horizonte: Autêntica, 2001.

BUTLER, Judith. Problemas de gênero. Rio de Janeiro: Civilização Brasileira, 2003.

CALDEIRA, Tereza Pires do Rio. Cidade de muros: Crime, segregação e cidadania. São Paulo: Edusp, 2000.

CAMPORESI, Piero. Bread of dreams. Chicago: The University of Chicago Press, 1996.

CANCLINI, Nestor Garcia. Consumidores e Cidadãos: conflitos multiculturais da globalização. Rio de Janeiro: Editora UFRJ, 2005, $5^{\text {a }}$ edição, 2005.

CANCLINI, Nestor Garcia. Culturas Híbridas. São Paulo: Edusp, 1998.

CANESQUI, Ana Maria. Notas sobre a produção acadêmica de antropologia e saúde na década de 80. In: ALVES, Paulo César \& MINAYO, Maria Cecília de Souza. Saúde e Doença: um olhar antropológico. Rio de Janeiro: Fiocruz, 1998. 
CANESQUI, Ana Maria; GARCIA, Rosa Wanda Diez. Antropologia e nutrição: um diálogo possivel. Manguinhos: Editora Fiocruz, 2005.

CAPATTI, Alberto. La pizza: Quand lê casse-croute des miserables passe a table.... Autrement. Serie Mutations (1989): Paris, número 206, 2001.

CAPATTI, Alberto \& MONTANARI, Massimo. La cuisine italienne: histoire d'une culture. Paris: Seuil, 1999.

CAPLAN, Pat. Food, health and identity. London: Routledge, 1997.

CARELLI, Mario. Carcamanos e comendadores. São Paulo: Editora Ática, 1985.

CARMO, Maria Silvia Micelli do \& PASSOS, Maria Consuelo. A mulher imigrante italiana e o uso da comida: uma experiência de transicionalidade. Mental: Barbacena, ano III, número 5, novembro, 2005.

CARONE, Edgard. A evolução industrial de São Paulo (1889-1930). São Paulo: Editora SENAC, 2001.

CARRARA, Sérgio. Uma 'tempestade' chamada Latour: a antropologia da ciência em perspectiva. Physis, volume 12, número 1, 2002.

CASCUDO, Luis da Câmara. A História da Alimentação no Brasil. Belo Horizonte: Itatiaia, 1983.

CASTIGLIONI, Aurélia. Imigração italiana no Espírito Santo: uma aventura colonizadora. In: BUSATTO, Luiz; FAÉ, Maria Inês; MUNIZ, Maria Izabel Perini. Vitória: UFES, 1998.

CASTRO, Josué. A geografia da fome. Rio de Janeiro: Civilização Brasileira, 2001.

CAVIGNAC, Julie Antoinette e DANTAS, Maria Isabel. Sistema alimentar e patrimônio alimentar: o chouriço no Seridó. Sociedade e Cultura, n.8, n.2, pp 63-78. jul/dez, 2005.

CENNI, Franco. Italianos no Brasil. São Paulo: Edusp, 2003.

CHANG, K. C. (Ed.) Food in Chinese Culture. New Heaven: Yale University Press, 1977.

CHÂTELET, Noelle. Le corps à corps culinaire. Paris: Seuil, 1998.

CINOTTO, Simone. Now that's Italian: Representations of Italian food in American popular magazines, 1950-2000. The Italian Academy for Advanced Studies in America. New York: Columbia University, s/d.

COLBARI, Antonia. Familismo e Ética no Trabalho: o legado dos imigrantes italianos para a cultura brasileira. Revista Brasileira de História: São Paulo, v.17, número 34, 1997.

COLLAÇO, Janine Helfst Leicht. Comer afuera en la ciudad de São Paulo - entre lo exótico y lo cotidiano. In: ALVAREZ, Marcelo \& MEDINA, Xavier. Patrimonio cultural y alimentación: diferentes perspectivas. Barcelona: Icaria, 2007.

COLLAÇO, Janine. Helfst Leicht. Mudanças conceituais em restaurantes. COLLAÇO, Janine Helfst Leicht; MONTEBELLO, Nancy di Pilla. Cortes e Recortes Volume 2. Brasília: Editora Senac, 2008. 
COLLAÇO, Janine Helfst Leicht. Comer fora - entre o exótico e o cotidiano. Temáticas: Campinas, vol.25/26, pp. 93-126, 2005.

COLLAÇO, Janine Helfst Leicht. Novidade, variedade e quantidade: os encontros e desencontros nas representações do comer em praças de alimentação em shopping-centers. Mneme, v.3, pp. $1-27,2004 a$.

COLLAÇO, Janine Helfst Leicht. Restaurantes de comida rápida, os fast-foods, em praças de alimentação de shopping-centers: transformações no comer. Revista Estudos Históricos: Rio de Janeiro, n.33, p-116-135, 2004b.

COLLAÇO, Janine Helfst Leicht. Um olhar antropológico sobre o hábito de comer fora. Revista Campos: Londrina, v.04, pp. 171-193, 2003.

COLLAÇO, Janine Helfst Leicht. Restaurantes de comida rápida em praças de alimentação de shopping-centers: Soluções à moda da casa. Dissertação (Mestrado em Antropologia Social) - Departamento de Antropologia da Faculdade de Filosofia, Letras e Ciências Humanas. São Paulo: Universidade de São Paulo, 2003.

CONNERTON, Paul. How Societies Remember. Edinburgh: Cambridge University Press, 1989.

CONNERTON, Paul. Seven types of forgetting. Memory Studies, vol.1 (1), 2008, pp. 59-71.

CONTRERAS, Jesus \& GRACIA-ARNÁIZ, Mabel. Alimentación y Cultura: perspectivas antropológicas. Barcelona: Ariel, 2005.

CONWAY, Martin. El inventario de la experiencia: memoria y identidad. In: PAEZ, D.; VALENCIA, J.F; PENNEBAKER, J.W.;RIMÉ, B. \& JODELET, D. (eds). Memorias colectivas de procesos culturales y politicos. Universidad del Pais Vasco, 1998.

COOK, Ian; CRANG, Philip. Japanese Food and Globalisation. Paper presented for submission for Food \& Foodways.

CORIGLIANO, Mada \& BAGGIO, Rodolfo. Italian culinary tourism on the internet. Paper apresentado em ATLAS Expert Meeting, Sondrio (Italy), 21-23 November 2002.

COUNIHAN, Carole. Around the tuscan table. New York: Routledge, 2004.

COUNIHAN, Carole \& VAN ESTERIK, Penny (eds.). Food and culture. New York: Routledge, 1997.

COUTO, Ronaldo Costa. Matarazzo (A travessia). São Paulo: Editora Planeta, 2004 a.

COUTO, Ronaldo Costa. Matarazzo (Colosso Brasileiro). São Paulo: Editora Planeta, 2004b.

CRANE, Susan A. Writing the individual back into collective memory. The American Historical Review, vol. 102, no.5, december, 1997, 1372-1385.

CRUZ, Heloisa de Faria. Na cidade, sobre a cidade: Cultura letrada, periodismo e vida urbana em São Paulo 1890/1915. Tese (Doutorado em História) - Departamento de História da Faculdade de Filosofia, Letras e Ciências Humanas. São Paulo: Universidade de São Paulo, 1994.

CWIERTKA, Katarzyna \& WALRAVEN, Boudewijn. Asian Food: The local and the global. Honolulu: Editorial Matter, 2001. 
CWIERTKA, Katarzyna. Eating the world: restaurant culture in early $20^{\text {th }}$ Japan. European Journal of East Asian Studies, vol.2; number 1, 2003.

CWIERTKA, Katarzyna. Moderna cozinha japonesa. São Paulo: Editora SENAC, 2008.

CYTRYNOWICZ, Roney. São Paulo e o front interno na Segunda Guerra Mundial. In: PORTA, Paula. História da Cidade de São Paulo v.3: a cidade na primeira metade do século XX. São Paulo: Paz e Terra, 2004.

CYTRYNOWICZ, Roney. Guerra sem Guerra. São Paulo: Geração Editorial, Edusp, 2000.

DAECTO, Marisa Midori. Comércio e vida urbana na cidade de São Paulo (1889-1930). São Paulo: Senac, 2001.

DaMATTA, Roberto. A Casa e a rua. Rio de Janeiro: Rocco, 1997a.

DaMATTA, Roberto. Carnavais, Malandros e heróis. Rio de Janeiro: Rocco, 1997b.

DaMATTA, Roberto. O que faz o brasil, Brasil? Rio de Janeiro: Rocco, 1999.

DANIEL, Jungla \& CRAVO, Veraluz. O valor social e cultural da alimentação. Boletim de Antropologia: Curitiba, vol. 2, n.4, abril 1989, pp. 69 a 83.

DeCERTEAU, Michel. A invenção do cotidiano. Petrópolis : Vozes, vol.1 1998.

DeCERTEAU, Michel, GIARD, Lucy \& MAYOL, Pierre. A invenção do cotidiano. Petrópolis: Vozes, vol.2, 1998.

DEFFONTAINES, Jean-Pierre. Le terroir, une notion polysémique. In: BÉRARD, Laurence; CEGARRA, Marie; DJAMA, Marcel; LOUAFI, Sélim; MARCHENAY, Philippe; ROUSSEL, Bernard; VERDEAUX, François (Comission Editoriel). Biodiversité et saviors naturalists locaux en France. Paris: Editions Cirad, Idar, IFB, Inra, 2005.

DELGADO, Andrea Ferreira. Cora Coralina: A poética do sabor. Revista Ilha: Florianópolis, v.4, n.1, pp.59-83, julho 2002.

DENKER, Joel. The world on a plate. Cambridge: Perseus Books, 2003.

DEVOTO, Fernando. Inventando a los italianos? Imágenes de los primeros inmigrantes en Buenos Aires. Anuário IEHS, vol7, Tandil, 1992.

DIAFERIA, Lourenço. Paulicéia: Brás. São Paulo: Boitempo Editorial, 2002.

DIAS, Maria Odila Leite da Silva. Quotidiano e Poder em São Paulo no século XIX. São Paulo: Editora Brasiliense, 1995.

DIAS, Reinaldo. Turismo e patrimônio cultural. São Paulo: Editora Saraiva, 2006.

DIEGUES JR., Manuel. Imigração, urbanização e indutrialização. Rio de Janeiro: Publicação do Centro Brasileiro de Pesquisas Educacionais, Instituto Nacional de Estudos Pedagógicos, Ministério da Educação e Cultura - Brasil, 1964.

DIEZ GARCIA, Rosa Wanda. Representações sociais da comida no meio urbano. Um estudo no centro da cidade de São Paulo. Dissertação (Mestrado em Psicologia) - Departamento de Psicologia do Instituto de Psicologia. São Paulo: Universidade de São Paulo, 1993. 
DIEZ GARCIA, Rosa Wanda. Práticas e comportamento alimentar no meio urbano: um estudo no centro da cidade de São Paulo. Caderno Saúde Pública: Rio de Janeiro, v.13 jul/set.1997. DI LEONARDO, Micaela. The varieties of ethnic experience. New York: Cornell University Press, 1984.

DOMINGUES, José Maurício. Sociologia da Cultura, Memória e Criatividade. Dados: Rio de Janeiro, vol.42, no. 2, 1999.

DOUGLAS, Mary. Implicit meanings. London: Routledge \& Kegan Paul, 1975.

DOUGLAS, Mary. Purity and danger. London: Routledge \& Kegan Paul, 1988.

DOUGLAS, Mary \& ISHERWOOD, Baron. O mundo dos bens. Rio de Janeiro: Editora UFRJ, 2004.

DUHART, Frederic. Consideraciones transcontinentales sobre la identidad cultural alimentaria. In: http://sincronia.cucsh.udg.mx/duhartf04htm, acessado em 18/10/2007.

DURHAM, Eunice. A pesquisa antropológica com populações urbanas: problemas e perspectivas. In: CARDOSO, Ruth (org.). A Aventura Antropológica. Rio de Janeiro: Paz e Terra, 1986.

DURKHEIM, Émile. Da divisão do trabalho social. São Paulo: Martins Fontes, 1999.

DUMONT, LOUIS. Homo hierarchicus. Chicago: The University of Chicago Press, 1980.

DUPONT, Florence. Gramática da alimentação e das refeições romanas. In: FLANDRIN, Jean-Louis \& MONTANARI, Massimo. A história da alimentação. São Paulo: Estação Liberdade, 1998.

ELIAS, Norbert. O processo civilizador. Rio de Janeiro: Jorge Zahar, 1994, v.1.

ELIAS, Norbert. O processo civilizador. Rio de Janeiro: Jorge Zahar, 1993, v.2.

ELIAS, Norbert \& SCOTSON, John L. Os estabelecidos e os outsiders. Rio de Janeiro: Editora Jorge Zahar, 2000.

ELY, Richard and McCABE, Alyssa. Gender differences in Memories for Speech. In: LEYDERDORFF, Selma et alli. Gender and memory. London: Oxford University Press, 1996.

ENCREVÉ, Pierre \& LAGRAVE, Rose-Marie. Trabalhar com Bourdieu. Rio de Janeiro: Bertrand, 2005.

ESPEITX, Elena. Patrimônio alimentario y turismo: uma relación singular. Pasos: Revista de Turismo y Patrimonio Cultural, vol.2, número, 2, pp. 193-213, 2004.

FANTASIA, Rick. Fast Food in France. Theory and Society, 24, 1995.

FALK, P. The consuming body. Sage: London, 1994.

FARB, Peter \& ARMELAGOS, George. Consuming Passions: The anhtropology of eating. Boston: Hougthon Mifflin Company, 1980.

FAUSTO, Boris (org.). Fazer a América. São Paulo: Edusp, 2000.

FAUSTO, Boris. Imigração: Cortes e Continuidades. In: NOVAIS, Fernando (coordenador geral), SCHWARCZ, Lilia (organizadora do volume). História da Vida Privada no Brasil: contrastes da intimidade contemporânea. São Paulo: Companhia das Letras, 1988, vol.4. 
FEATHERSTONE, Mike (org.). Cultura Global. Petrópolis: Editora Vozes, 1999.

FERGUSON, Priscilla Parkhurst \& ZUKIN, Sharon. What's Cooking?. Theory and Society, 24, pp 193-199, 1995.

FERGUSON, Priscilla Parkhurst. Is Paris France?. The French Review, volume 73, número 6, pp 1052-1064, Maio, 2000.

FIDDES, Nick. The omnivore's paradox. In: MARSHALL, David. Food choice and the consumer. Glasgow: Blackie Academic \& professional, 1995.

FINE, Gary Alan. Wittgenstein's kitchen: Sharing neaning in restaurant work. Theory and Society, 24, 1995.

FINKELSTEIN, Joanne. Dinning out. New York: New York Universtiy Press, 1989.

FINKELSTEIN, Joanne. Dinning out: the hipperreality of appetite. In: SCAPP, Ron \& SEITZ, Brian. Eating culture. Albany: State University of New York Press, 1998.

FISCHER, Michael M.J. Ethnicity and the Post-Modern Arts of Memory. In: CLIIFFORD, James \& MARCUS, George E. Writing Culture. Los Angeles: University of California Press, 1986.

FISCHLER, Claude. L'Homnivore. Paris: Édition Odile Jacob, 1990.

FISCHLER, Claude. Food, self and identity. Social Science Information, vol. 27, n.2, june, 1988.

FLANDRIN, Jean-Louis \& MONTANARI, Massimo. História da Alimentação. São Paulo: Estação Liberdade, 1998.

FLANDRIN, Jean-Louis. A distinção pelo gosto. In: ARIÈS, Philippe \& DUBY Georges. História da Vida Privada. São Paulo: Cia . das Letras, 1991, vol. 3.

FORJAZ, Maria Cecília. Lazer e consumo cultural das elites. Revista Brasileira de Ciências Sociais, vol. 3, n.6, fevereiro, 1988.

FOUCAULT, Michel. A história da sexualidade. Rio de Janeiro: Graal, 1988.

FRANCO, Ariovaldo. De caçador a gourmet. São Paulo: Ed. Senac, 2001.

FREITAS, Affonso A. de. Tradições e Reminiscências Paulistanas. São Paulo: Edusp, 1985.

FREITAS, Maria do Carmo Soares. Agonia da fome. Salvador: Edufba/Fiocruz, 2003.

FREITAS, Sônia Maria de. Efalam os imigrantes...Tese (Doutorado em História) - Departamento de História da Faculdade de Filosofia, Letras e Ciências Humanas. São Paulo: Universidade de São Paulo, 2001.

FREYRE, Gilberto. Casa-grande e senzala. Rio de Janeiro: Record, 1999.

FREYRE, Gilberto. Açúcar. São Paulo: Cia . das Letras, 1997.

FRIEIRO, Eduardo. Feijão, angu e couve. Belo Horizonte: Reitoria da Universidade de Minas Gerais, 1966.

FRY, Peter. Feijoada e soul food: notas sobre manipulação de símbolos étnicos e nacionais. Ensaios de Opinião, 2+2, Inubia, 1977. 
FRUGOLIJR., Heitor. Os shopping-centers de São Paulo e as formas de sociabilidade no contexto urbano. Dissertação (Mestrado em Antropologia Social) - Departamento de Antropologia da Faculdade de Filosofia, Letras e Ciências Humanas. São Paulo: Universidade de São Paulo, 1989.

FRUGOLI JR. Heitor. O urbano em questão na antropologia: interfaces com a sociologia. Revista de Antropologia: São Paulo, USP, vol. 48 no. 1, 2005.

FUMEY, Gilles. Pizza Conneexión. Un séduction transculurelle. Resenha de livro (Sylvie Sanchez). In: http:// www. café-geo.net/article.php3?id_article=1068

GABACCIA, Donna. We are what we eat. Cambridge: Harvard University Press, 1998.

GARCIA, Janaína A.B. Mulheres Exemplares: vidas contadas no anuário de senhoras de 1953. Revista História Hoje: São Paulo, número 5, 2004.

GARINE, Igor. The diet and nutrition of human populations. In: INGOLD, Tim (ed.). Companion Encyclopedia of Anthropology. London: Routledge, 1994.

GEERTZ, Clifford. The Interpretatio of Cultures. EUA: Basic Books, 1973.

GEERTZ, Clifford. Negara. Lisboa: Difel, 1991.

GEERTZ, Clifford. O Saber Local. Petrópolis: Vozes, 1997.

GIARD, Lucy. Cozinhar. In: DeCERTEAU, Michel. A invenção do cotidiano 2. Petrópolis: Vozes, 1996.

GIDDENS, Anthony. As consequências da modernidade. São Paulo: Unesp, 1996.

GIDDENS, Anthony; BECK, Ulrich \& LASH, Scott. Modernização Reflexiva. São Paulo: Unesp, 1997.

GIDDENS, Anthony. Modernidade e identidade. Rio de Janeiro: Jorge Zahar, 2002.

GIRARDELLI, Davide. Commodified Identites: The myth of Italian Food in The United States. Journal of Communication Inquiry, 28:4(October 2004), 303-324.

GOFTON, Les. Convenience food and the moral status of consumer practices. In: MARSHALL, David. Food choice and the consumer. Glasgow: Blackie Academic \& professional, 1995.

GOODE, Judith; THEOPHANO, Janet and CURTIS, Karen. Continuity and change. In: BROWN, Linda Keller; MUSSELL, Kay. Ethnic and regional Foodways in the United States. Knoxville: Kentrucky University Press, 1984.

GOODY, Jack. Cooking, cuisine and class. Cambridge: Cambridge University Press, 1982. GOODY, Jack. Food and love. London: Verso, 1998.

GUIRAO, Javier Eloy Martínez. Los McDonald's: homogeniezación y sociabilidade. Un estudio antropológico. Gazeta de Antropologia, no. 19, 2003.

GRÜNSPUN, Haim. Anatomia de um bairro: O Bixiga. São Paulo: HRM Editores Associados, 1979.

HALBWACHS, Maurice. La mémoire collective. Paris: Albin Michel, 1997. 
HALL, Michael. Imigrantes na cidade de São Paulo. In: PORTA, Paula (org.). História da Cidade de São Paulo. São Paulo: Paz e Terra, 2004.

HALL, Michael C.; SHARPLES, Liz; MITCHELL, Richard; MANCIONIS, Niki (eds.). Food tourism around the world. Massachussets: Butterworth Heinemann, 2003.

HANNERZ, Ulf. Cultural complexity. New York: Columbia University Press, 1992.

HANNERZ, Ulf. Conexiones transnacionales. Madri: Ediciones Catédra, 1998.

HANNERZ, Ulf. Entrevista: Os limites de nosso auto-retrato. Antropologia urbana e globalização. Revista Mana: Rio de Janeiro, (50), pp 149-155, 1999.

HARBOTLLE, Lynn. Taste and embodiment: the food preferences of Iranians in Britain. In: MACBETH, Helen. Food preferences and taste. Oxford: Berghahn Books, 1997.

HARRIS, MARVIN. Bueno para comer. Madri: Alianza Editorial, 1997.

HARVEY, David. A condição pós-moderna. Lisboa: Edições Loyola, 2001.

HARZIG, Christhiane. Women move from European Countryside to Urban America. In: HARZIG, Christhiane (ed.). Peasant Maids - City Women. New York: Cornell University Press, 1997.

HELSTOSKY, Carol. Recipe for the nation: reading Italian History through La Scienza in Cucina and La Cucina Futurista. Food \& Foodways, 1, pp 113-140, 2003.

HELSTOSKY, Carol. Garlic \& Oil: food and politics in Italy. New York: Berg, 2004.

HJLALAGER, Anne-Mette and RICHARDS, Greg. Tourism and Gastronomy. London: Routledge, 2002.

HOBSBAWN, Eric \& RANGER, Terence. A invenção das tradições. Rio de Janeiro: Paz e Terra, 1997.

HOLSTON, James. A cidade modernista. São Paulo: Cia. Das Letras, 1993.

HOLTZMAN, Jon. Food and Memory. Annual Review of Anthropology, número 35, pp. 361378, 2006.

HOMEM, Maria Cecília Naclério. Café, Indústria e Cozinha. Passagem da cozinha rural a urbana: São Paulo, 1830-1918. I Seminário de História do Café: História e Cultural Material Museu Republicano Convenção de Itu, Museu Paulista/USP, novembro de 2006.

HUTCHINSON, Bertram. Mobilidade e Trabalho: Um estudo na cidade de São Paulo. Rio de Janeiro: Centro Brasileiro de Pesquisas Educacionais, INEP - Ministério da Educação e Cultura, 1960.

HUTTER, Lucy Maffei. A imigração italiana no Brasil (séculos XIX e XX): Dados para a compreensão desse processo. BONI, Luís A. de (org.) A presença italiana no Brasil: Quem somos! Itália viva! Um futuro que vem de longe. Porto Alegre/Torino, Escola Superior de Teologia/Fondazione Giovanni Agnelli, volume I, 1987

IANNI, Constantino. Homens sem paz. Rio de Janeiro: Civilização Brasileira, 1972. 
JACOB, Heinrich Eduard. Seis mil anos de pão. São Paulo: Nova Alexandria, 2003.

JACOBS, Marc and SCHOLLIERS, Peter (Eds.). Eating out in Europe: picnics, gourmet dinning and snacks since the late eighteenth century. New York: Berg, 2003.

JAKOBSON, Roman. Essais de linguistique générale. Paris : Editions Minuit, 1963.

JAMES, Roberta. Halal Pizza: Food and Culture in a Busy World. The Australian Journal of Anthropology, 15:1, pp. 1-11, 2004.

KALCIK, Susan. Symbol and Performance. In: BROWN, Linda Keller; MUSSELL, Kay. Ethnic and regional Foodways in the United States. Knoxville: Kentrucky University Press, 1984.

KANSTEINER, Wulf. Finding Meaning in Memory: a methodological critique of collective memory studies. History and Theory, number 41, May, 2002, pp. 179-197.

KANT DE LIMA, Roberto. Cultura do desperdício ou política da opulência?. In: EIGENHEER, Emílio Maciel (org.). Raízes do Desperdício. Rio de Janeiro: Iser, 1993.

KATZ, ESTHER; ROBERT, Pascale de; VELTHEM, Lúcia Van; ALMEIDA, Mauro; SANTILLI, Juliana; ELLOY, Ludivine; RIZZI, Roberta e EMPERAIRE, Laure. La valorización del patrimonio culinario amazónico a través de las indicaciones geográficas. In: ALVAREZ, Marcelo \& MEDINA, Xavier (Eds.) Identidades en el plato. El patrimonio cultural alimentario entre Europa y America. Barcelona: Icaria, 2008.

KATZ, Esther \& SUREMAIN, Charles-Edouard de. Modèles alimentaires et recompositions sociales en Amérique latine. Aofood, Paris,S4, Maio 2008 disponível em: htpp:// aof.revues. org/index2763.html. Vários acessos.

KLEIN, Kerwin Lee. On the emergence of Memory in Historical Discourse. Representations, no. 69, Special Issue: Grounds for Remembering, pp. 127-150, winter, 2000.

KOGURUMA, Paulo. A saracura: ritmos sociais e temporalidades da metrópole do café (1890-1920). Revista Brasileira de História: São Paulo, v.19, no. 38, pp. 81-99, 1999.

KOSMINSKY, Ethel. Por uma etnografia feminista das migrações internacionais: dos estudos de aculturação para os estudos gêneros. Revista Estudos Feministas: Florianópolis, 15(3), pp. 773-804, setembro-dezembro, 2007.

KOTHE, Flávio (org.). Walter Benjamin. São Paulo: Ática, 1991.

KUPER, Jessica. The anthropologist's cookbook. London: Routledge \& Kegan Paul, 1997.

LaCECLA, Franco. Pasta and pizza. Chicago: Prickly Paradigm Press, 2007.

LAFERTÉ, Gilles. La production d'identités territoriales à usage commercial dans l'entredeux-guerres en Bourgogne. Cahiers d'economie et sociologie rurales, n.62, 2002.

LANGLE, Henry-Melchior de . Le petit monde des cafès et débits parisiens au XIXe. Siècle. Paris: Puf, 1990. 
LAROCHE, Michel; CHANKON, Kim; TOMIUK, Marc A. Italian Ethnic identity and its relative impact on the consumption of convenience traditional foods. British Food Journal, col.101, número 3, pp. 201-228, 1999.

LATOUR, Bruno. Jamais fomos modernos. São Paulo: Editora 34, 1994.

LATOUR, Bruno. How to talk about the body? The normative dimension of science studies. Body and society. Special issue, November 2002.

LEITCH, Alison. The social life of Lardo: Slow Food in Fast times. The Asia Pacific Journal of Anthropology (formerly Canberra Anthropology), 1: p. 103-118. Apud: SUTTON, David E. Remembrance of Repasts. New York: Berg, 2001.

LEITE, Miriam Moreira. Retratos de Família. São Paulo: Editora da Universidade de São Paulo, 2001.

LEMOS, Carlos A. O morar em São Paulo nos tempos dos italianos. In: BONI, Luís A. de (org.) A presença italiana no Brasil. Porto Alegre/Torino: Escola Superior de Teologia/Fondazione Giovanni Agnelli, volume II, 1990.

LEMOS, Carlos A . C. O álbum de Afonso.São Paulo: Pinacoteca do Estado, 2001.

LEVENSTEIN, Harvey. Paradox of plenty. California: Universtiy of California Press, 2003 a. LEVENSTEIN, Harvey. Revolution at the table. Califórnia: University Of Califórnia Press, $2003 \mathrm{~b}$.

LÉVI-STRAUSS, Claude. Antropologia Estrutural. Rio de Janeiro: Tempo Brasileiro, 1996.

LÉVI-STRAUSS, Claude. O pensamento selvagem. Campinas: Papirus, 1997.

LÉVI-STRAUSS, Claude. The Culinary Triangle. In: COUNIHAN, Carole \& VAN ESTERIK, Penny (eds). Food and culture. New York: Routledge, 1997.

LÉVI-STRAUSS, Claude. O cru e o cozido. São Paulo: Brasiliense, 1991.

LÉVI-STRAUSS, Claude. Totemismo hoje. Lisboa: Edições 70, 1986.

LÉVI-STRAUSS, Claude. Raça e História. Porto: Editorial Presença, 1973.

LÉVI-STRAUSS, Claude. L'origine des manières de table. Paris: Plon, 1968.

LIMA, Claúdia. Tachos e Panelas. Recife: Editora da Autora, 1999.

LIMA, Vivaldo da Costa. Para uma antropologia da alimentação. Alteridades, n. 2,abr/set, 1995.

LIMA, Vivaldo da Costa. As dietas africanas no sistema alimentar brasileiro. In: CAROSO, Carlos \& BACELAR, Jeferson (orgs.). Faces da tradição afro-brasileira. Rio de Janeiro/ Salvador: CEAO, 1999.

LOFEGO, Silvio Luiz. Memória de uma metrópole: São Paulo na obra de Ernani Silva Bruno. São Paulo: AnnaBlume/FAPESP, 2004.

LONG, Lucy M. Culinary Tourism. Lexington: University Press of Kentucky, 2003.

LOVE, John. McDonald's: Behind the Arches. New York: Bantam Books, 1995. 
LUCA, Tania Regina de. As sociedades de socorros mútuos italianas em São Paulo. In: BONI, Luís A. de (org.) A presença italiana no Brasil. Porto Alegre/Torino: Escola Superior de Teologia/Fondazione Giovanni Agnelli, volume II, 1990.

LUPTON, Deborah. Food, memory and meaning: the symbolic and social nature of food events. The Sociological Review, vol.42, no. 4, November 1994.

LUPTON, Deborah. Food, body and the self. London: Sage, 1996.

MACHADO, Maria Lúcia Büher. Construindo os "anjos da casa": trabalho fabril feminino e casamento entre décadas de 40 e 60. Mulher e Trabalho: Porto Alegre: vol.4, p. 61-72, 2004.

MAGNANI, José Guilherme C. \& TORRES, Lilian de Lucca (orgs.). Na metrópole. São Paulo: Edusp, 2000.

MAGNANI, José Guilherme C. A cidade de Tristes Trópicos. Revista de Antropologia: São Paulo: vol. 42, números 1 e 2, 1999.

MAGNANI, José Guilherme C. Transformações na cultura urbana das grandes metrópoles. In: MOREIRA, Alberto da Silva. Sociedade Global: cultura e religião. Petrópolis: Vozes, 1998.

MAGNANI, José Guilherme C. Discurso e representação ou de como os baloma de Kiriwana podem reencarnar-se nas atuais pesquisas. In: CARDOSO, Ruth (org.). A aventura antropológica. Rio de Janeiro: Paz e Terra, 1996.

MARCUS, George. Identidades passadas, presentes e emergentes: requisitos para etnografia sobre a modernidade no final do século XX ao nível mundial. Revista de Antropologia: São Paulo, número 34, 1991.

MARRONE, Gianfranco. A narrativa do gosto: Releitura de Brillat-Savarin. In: LANDOWSKI, Eric \& FIORIN, José Luiz (eds.). O gosto da gente, o gosto das coisas. São Paulo: EDUC, 1997.

MARSHALL, David. Eating at home: Meals and food choice. In: MARSHALL, David. Food choice and the consumer. Glasgow: Blackie Academic \& professional, 1995.

MARTINS, José de Souza. O migrante brasileiro na São Paulo estrangeira. In: PORTA, Paula (org.). História da Cidade de São Paulo. São Paulo: Paz e Terra, 2004.

MASPLÈDE, Jean-François. Trois étoiles au Michelin. Paris: Editions Gründ, 2004.

MATOS, Edilene et al. A presença de Castelo. São Paulo: Humanitas/FFLCH-USP/Instituto de Estudos Brasileiros, 2003.

MATOS, Maria Izilda Santos de. Cotidiano e Cultura: história, cidade e trabalho. Bauru: EDUSC, 2002.

MAUÉS, Raymundo Heraldo \& MAUÉS, Maria Angélica Motta. O modelo da "reima": representações alimentares em uma comunidade amazônica. Anuário Antropológico: Rio de Janeiro: Ed. Tempo Brasileiro, 1977.

MEDINA, Cremilda. Tchau Itália, Ciao Brasil. São Paulo: CJE/ECA/USP, 1983. 
MEDINA, F. XAVIER. Alimentation et identités chez les inmigrants basques en Catalogne. Aofood: Paris, número 1, 2001 disponível em: htpp:// aof.revues.org/index2763.html. Vários acessos.

MENASCHE, Renata (org.). A agricultura familiar à mesa. Porto Alegre: Editora UFRGS, 2007.

MENNEL, Stephen; MURCOTT, Anne \& VAN OTERLOO, Anekke. The sociology of food. Londres: Sage Publications, 1992.

MENNELL, Stephen. All manners of food. Illinois: University of Illinois Press, 1996.

MELLO, João Manuel Cardoso \& NOVAIS, Fernando. Capitalismo tardio e sociabilidade moderna. In: SCHWARCZ, Lilia Moritz (org.). História da vida privada no Brasil. São Paulo: Cia. Das Letras, 1998.

MESSER, Ellen. Anthropological Perspectives on Diet. Annual Review of Anthropology, vol. 13, 1984.

MILLER, Daniel. Consumption: critical concepts in the social sciences. London: Routledge, 2001.

MINTZ, Sidney. Food and anthropology: a brief overview. Revista Brasileira de Ciências Sociais (on line). Outubro 2001, vol.16, no. 47 (cited 28 de outubro 2002), p.31-42. Available from World Wide Web: http://www.scielo.br/scielo.php?script=sci_artex\&pid=S010269092001000300002\&Ing=en\&nrm=iso

MINTZ, Sidney. Tasting food, tasting freedom. Boston: Beacon Press, 1996.

MINTZ, Sidney. Sweetness and Power: The place of sugar in modern history. New York: Penguin Books, 1985.

MOLZ, Jennie Germann. Eating Difference: The Cosmopolitan Mobilities of Culinary Tourism. Space and Culture, vol.10, no.1, pp. 77-93, february, 2007.

MONTANARI, Massimo. Food is culture. New York: Columbia University Press, 2004.

MORENO, Júlio. Memórias do Armandinho do Bixiga. São Paulo: SENAC, 1996.

MOTA, Carlos Guilherme. São Paulo: exercício da memória. Estudos Avançados, 12 (48), 2003.

MOURA, Esmeralda Blanco Bolsonaro de. Imigrantes italianos em São Paulo na passagem para o século XX . In: PRIORE, Mary Del (org.). Revisão do Paraíso: os brasileiros e o estado em 500 anos de história. Rio de Janeiro: Campus, 2000.

MUNHOZ, Sidnei J. Cidade ao avesso: desordem e progresso em São Paulo, no limiar do século XX. Tese (Doutorado em História) - Departamento de História da Faculdade de Filosofia, Letras e Ciências Humanas. São Paulo: Universidade de São Paulo, 1997.

MURCOTT, Anne. Family Meals - a thing of the past? In: CAPLAN, Pat. Food, health and identity. London: Routledge, 1997. 
MURCOTT, Anne. Raw, cooked and proper meals at home. In: MARSHALL, David. Food choice and the consumer. Glasgow: Blackie Academic \& professional, 1995.

MURCOTT, Anne. On the social significance of the "cooked dinner" in South Wales. Social Science Information, vol. 21, ns. 4/5, 1982.

MURRIETA, Rui Sérgio Sereni. Dialética do sabor: alimentação, ecologia e vida cotidiana em comunidades ribeirinhas da Ilha de Ituqui, Baixo Amazonas, Pará. Revista de Antropologia: São Paulo, vol. 44, número 2, 2001.

NOVAES, Sylvia Caiuby. Jogo de Espelhos. São Paulo: Edusp, 1993.

OHNUKI-TIERNEY, Emiko. McDonald's in Japan: Changing Manners and Etiquette. In: WATSON, James L. (ed.) Golden Arches East. California: Stanford University Press, 1997.

OLIVEIRA, Flávia Arlanch Martins de. Padrões Alimentares em mudança: a cozinha italiana no interior paulista. Revista Brasileira de História: São Paulo, vol. 26, número 51, pp.47-62, 2006.

OLIVEIRA, Roberto Cardoso. Os (des) caminhos da identidade. Revista Brasileira de Ciências Sociais (RBCS), vol. 15, número 42, fevereiro, 2000.

ORTIZ, Renato. Cultura e Modernidade. São Paulo: Brasiliense, 1991.

ORTIZ, Renato. Cultura brasileira e identidade nacional. São Paulo: Brasiliense, 2003.

PARASECOLI, Fabio. Food Culture in Italy. Westport: Greenwood Press, 2004.

PEIRANO, Mariza. A favor da etnografia. Rio de Janeiro: Relume-Dumará, 1995.

PENTEADO, Jacob. Belenzinho, 1910. São Paulo: Carrenho Editorial/Narrativa Um, 2003.

PEREIRA, João Baptista Borges. Perfis da italianidade no Brasil. In: MATTOS, Edilene. A presença de Castello. São Paulo: Humanitas/FFLCH-USP/Instituto de Estudos Brasileiros, 2003.

PETRONE, Maria Thereza Schorer. Abolição e imigração italiana em São Paulo. In: BONI, Luís A. de (org.). A presença italiana no Brasil. Porto Alegre/Torino: Escola Superior de Teologia/ Fondazione Giovanni Agnelli, volume II, 1990.

PILCHER, James. Que vivan los tamales! Albuquerque: University of New Mexico Press, 1998.

PILLA, Maria Cecília Barreto Amorim. Labores, quitutes e panelas: em busca do lar ideal. Cadernos Pagu (30): Campinas, pp. 329-343, janeiro/junho, 2008.

PINTAUDI, Silvana Maria \& FRUGOLI JR., Heitor (orgs.). Shopping Centers: Espaço, Cultura e Modernidade nas cidades brasileiras. São Paulo: Unesp, 1992.

PINTO, Ana Stela de Sousa. Na mesa com Giovanni. In: MEDINA, Cremilda. Tchau Itália, Ciao Brasil. São Paulo: CJE/ECA/USP, 1983.

PINTO, Maria Inez Machado Borges. Cotidiano e Sobrevivência: A vida do trabalhador pobre na cidade de São Paulo, 1890 a 1914. Tese (Doutorado em História) - Departamento de História da Faculdade de Filosofia, Letras e Ciências Humanas. São Paulo: Universidade de São Paulo, 1984. 
PINTO, Maria Inez Machado Borges. Urbes industrializada: o modernismo e a paulicéia como ícone da brasilidade. Revista Brasileira de História: São Paulo, v.21, número 42, 2001, p. 435 455.

PITTE, Jean-Robert \& LEMPS, Alain. Les restaurants dans le monde à travers les âges. Paris: Éditions Gallimard, 1990.

PITTE, Jean-Robert. Gastronomia francesa. Porto Alegre: L\&PM, 1993.

PORTA, Paula. História da Cidade de São Paulo: A cidade na primeira metade do século XX. São Paulo: Paz e Terra, 2004, vol. 3.

POLLACK, Michael. Memória, Esquecimento, Silêncio. Revista de Estudos Históricos: Rio de Janeiro, vol.2, número 3, 1989.

POLLACK, Michael. Memória e Identidade Social. Estudos Históricos: Rio de Janeiro, vol. 5, número 10, pp.200-212, 1992.

POULAIN, Jean-Pierre. Sociologies de L'alimentation. Paris: PUF, 2002.

RAGO, Margaretn. Do cabaré ao lar: a utopia da cidade disciplinar. Rio de Janeiro: Editora Paz e Terra, 1985.

RAGO, Margareth. A invenção do cotidiano na metrópole: sociabilidade e lazer em São Paulo, 1900-1950. In: PORTA, Paula. História História da Cidade de São Paulo: A cidade na primeira metade do século XX. São Paulo: Paz e Terra, 2004, vol.3

REIS FILHO, Nestor Goulart. São Paulo e outras cidades: produção social e degradação dos espaços urbanos. São Paulo: Hucitec, 1994.

REVEL, François. Um banquete de palavras. São Paulo: Cia . das Letras, 1996.

RIAL, Carmem. Fast-Food: A nostalgia da estrutura perdida. In: Horizontes Antropológicos: Porto Alegre, número 4, 1996.

RIAL, Carmem. Le goût et l'image: ça se passe comme ça chez les fast-foods - étud anthropologicque de la restauration rapide. Université de Paris Descartes, Sorbonne, 1992.

RIAL, Carmen. Rumores sobre alimentos: o caso dos fast-foods. Antropologia em primeira mão: Florianópolis, 1996.

RIAL, Carmen. Fast-food: a nostalgia da estrutura perdida. Horizontes Antropológicos: Porto Alegre, número 4, 1996.

RIBEIRO, Gustavo Lins. O que faz o Brasil, Brazil. Jogos identitários em San Francisco. Brasília: Série Antropologia/UnB, número 237, 1998.

RIBEIRO, Suzana Barretto. Italianos do Brás: Imagens e Memórias. São Paulo: Editora Brasiliense, 1994.

RICHARDS, Audrey. Hunger and work in a Savage tribe. London: Oxford University Press, 1939.

RITZER, George. The McDonaldization of society. Thousand Oaks: Pine Forge, 1993. 
PORTUGUEZ, Anderson Pereira. Turismo, Memória e Patrimônio Cultural. São Paulo: Roca, 2004.

ROCHA, Everardo. A sociedade do sonho. Rio de Janeiro: Mauad, 1995.

RODRIGUES, Jayme. Por uma história da alimentação na cidade de São Paulo (décadas de 1920 a 1950). Artigo apresentado nos Seminários de Pesquisa - Curso de História da Universidade Federal de São Paulo, Campus Guarulhos como resultado das atividades de pós-doutorado realizadas na Faculdade de Saúde Pública da USP entre junho de 2005 e junho de 2006 com financiamento FAPESP.

ROGATTO, Geraldo Matheus. Achiropita, Fettucine e Vinho: sobre a italianidade e a colônia italiana de São Paulo. In: BONI, Luís A. de (org.). A presença italiana no Brasil. Porto Alegre/ Torino: Escola Superior de Teologia/Fondazione Giovanni Agnelli, volume II, 1990.

ROWE, William and SCHELLING, Vivian. Memory and modernity: popular culture in Latin America. New York: Verso, 1991.

SAHLINS, Marshall. Cultura e Razão prática. Rio de Janeiro: Zahar Editores, 2003 [1979].

SAHLINS, Marshall. Ilhas de história. Rio de Janeiro: Jorge Zahar Editor, 1990.

SAHLINS, Marshall. Cosmologias do Capitalismo: O setor transpacífico do "Sistema Mundial". Religião e Sociedade: Rio de Janeiro, ISER, v.16, n.1/2, 1992.

SALLES, Maria do Rosário R. Imigração, Família e redes sociais: a experiência dos "deslocados de guerra" em São Paulo, no pós Segunda Guerra Mundial. XIV Encontro Nacional de Estudos Populacionais, ABEP, realizado em Caxambu/MG, setembro de 2004.

SALLES, Maria do Rosário R. Os médicos italianos em São Paulo - 1890-1930: Um projeto de ascensão social. São Paulo: Sumaré, 1997.

SANTOS, Carlos José Ferreira dos. Nem tudo era italiano: São Paulo e pobreza (1890-1915). São Paulo: AnnaBlume/Fapesp, 2003.

SANTOS, Cecília Rodrigues. Novas Fronteiras e novos pactos para o patrimônio cultural. São Paulo em Perspectiva: São Paulo, 15 (2), pp. 43-48, 2001.

SCHLOSSER, Eric. Fast Food Nation. New York: Houghton Mifflin, 2001.

SCHMIDT, Afonso. São Paulo de Meus Amores. São Paulo: Editora Paz e Terra, 2003.

SCHPUN, Mônica Raisa. Luzes e sombras da cidade (São Paulo na obra de Mario de Andrade. Revista Brasileira de História: São Paulo, vol.23, número 46, 2003.

SCHLÜTER, Regina. G. Gastronomia e Turismo. São Paulo: Aleph, 2003.

SCHNEIDER, Arnd. The Transcontinental Construction of European Identities: A view from Argentina. Anthropological Journal of European Cultures, 5(1), pp. 95-105, 1996.

SENNETT, Richard. O declínio do homem público. São Paulo: Cia . das Letras, 1988.

SERVENTI, Silvano \& SABBAN, Françoise. Pasta: The story of a universal food. New York: Columbia of University Press, 2000. 
SESSO, Jr. Geraldo. Retalhos da velha São Paulo. São Paulo: Maltese, 1995.

SHORTRIDGE, Barbara G. \& SHORTRIDGE, James R. The taste of American Place. Maryland: Rowman \& Littlefield Publishers, 1998.

SILVA, Regina Helena Alves da. São Paulo: A invenção da metrópole. Tese (Doutorado em História) - Departamento de História da Faculdade de Filosofia, Letras e Ciências Humanas. São Paulo: Universidade de São Paulo, 1997.

SILVA, Vagner Gonçalves da. O antropólogo e sua magia. São Paulo: Edusp, 2000.

SIMMEL, Georg. A metrópole e a vida mental. In: VELHO, Otávio (org.). O fenômeno urbano. Rio de Janeiro: Zahar, 1976.

SIMMEL, Georg. Sociabilidade - Um exemplo de Sociologia pura ou formal. In: MORAES, E. (org.). São Paulo: Ática, 1983. (Coleção Grandes Cientistas Sociais)

SIMOONS, Frederick. Eat not this flesh. Wisconsin: The University of Wisconsin Press, 1994. SOUSA JR., Vilson Caetano. A cozinha e os truques: usos e abusos das mulheres de saia e o povo de azeite. In: CAROSO, Carlos \& BACELAR, Jeferson (orgs.). Faces da tradição afrobrasileira. Rio de Janeiro/Salvador: CEAO, 1999.

SPANG, Rebecca. The Invention of the restaurant. Harvard: Harvard University Press, 2000.

STOLER, Ann Laura \& STRASSLER, Karen. Castings for the colonial: Memory work in "new order” Java. Comparative Study of Society and History, vol. 42, Issue 1, jan, 2000.

SUTTON, David. Remembrances of Repasts: an Anthropology of food and memory. Oxford: Berg, 2001.

THOMAS, Mandy. Transitions in Taste in Vietnam and the Diaspora. The Australian Journal of Anthropology, 15:1, pp. 54-67, 2004.

TIRABASSI, Madalena. Italian Cultural Identity and Migration: Italian Communities Abroad and Italian Cultural identity through time. In: JANNI, Paulo \& McLEAN, George F. The essence of Italian culture and the challenge of a global age. Cultural Heritage and Contemporary Change. Series IV, West Europe, Volume 5. Livro virtual consultado no sitio: www.crvp.org/ bok/Series04/IV-5/contents.htm; 16/11/2004.

TOUSSAINT-SAMAT, Maguellone. History of food. Oxford: Blackwell Publishers, 1994.

TRENTO, Angelo. Do outro lado do Atlântico: um século de imigração italiana no Brasil. São Paulo: Editora Nobel: Istituto Italiano di Cultura di San Paolo: Instituto Cultural ÍtaloBrasileiro, 1989.

TRUZZI, Oswaldo. Etnias em convívio: o bairro do Bom Retiro em São Paulo. Revista Estudos Históricos: Rio de Janeiro, número 28, 2001.

TURNER, Victor. Dramas, fields and metaphors: symbolic action in human society. Ithaca and London: Cornell University Press, 1975.

TURNER, Victor, O Processo ritual. Petrópolis: Vozes, 1974. 
VELHO, Gilberto. Individualismo e cultura. Rio de Janeiro: Jorge Zahar, 1987.

VELHO, Gilberto. Patrimônio, negociação e conflito. Revista Mana: Rio de Janeiro, 12 (1), pp. 237-248, 2006.

VAN DEN BERGHE, PIERRE L. Ethnic Cuisine: culture in nature. Etnhic and Racial Studies, Vol. 7 Number 3, July 1984.

VAN OTTERLOO, Anneke. Chinese and Indonesian restyaurants and the taste for the exotic food in Neatherlands: a local-global trend. In: CWIERTKA, Katarzyna \& WALRAVEN, Boudewijn. Asian Food: The global and the local. Honolulu: University of Hawai'I Press, 2001.

VELlOSO, Mônica Pimenta. A Brasilidade Verde-Amarela: nacionalismo e regionalismo paulista. Revista Estudos Históricos: Rio de Janeiro, vol.6, número 11, pp. 89-112, 1993. VISSER, Margareth. O ritual do jantar. Rio de Janeiro: Campus, 1998.

WARDE, Alan \& HETHERINGTON, Kevin. English households and routine foods practices: a research note. The Sociological Review, vol 42, n.4, november, 1994.

WARDE, Alan. Consumption, food and taste. Londres: Sage, 1997.

WARDE, Alan \& MARTENS, Lydia. The social and symbolic significance of Ethnic Cuisine in England: New cosmopolitanism and old xenophobia. Sociologisk Arbok, número 1, 1998.

WARDE, Alan \& Martens, Lydia. Eating out. Cambridge: Cambridge University Press, 2000

WATSON, James L. Golden Arches East. California: Stanford University Press, 1997.

WEBER, Eugen. Fin de siècle. Paris: Fayard, 1986.

WOOD, Roy. Dining out on sociological neglect. British Food Journal, vol.96, issue 10, 10-15, 1994.

WOORTMANN, Ellen. Padrões tradicionais e modernização: comida e trabalho entre camponeses teuto-brasileiros. In: MENASCHE, Renata (org.). A agricultura familiar à mesa. Porto Alegre: Editora UFRGS, 2007.

WOORTMANN, Klaas. Hábitos e Ideologia Alimentares em Grupos Sociais de Baixa Renda. Brasília: Relatório Final. 1978.

ZALUAR, Alba. A máquina e a revolta. São Paulo: Brasiliense, 1985.

ZANINI, Maria Catarina Chitolina. A família como patrimônio: a construção de memórias entre descendentes de imigrantes italianos. Revista Campos: Londrina, 5 (1), pp. 53-67, 2004. ZANINI, Maria Catarina Chitolina. Migrações do passado e do presente: uma análise cruzando gênero, etncidade e preconceito. Florianópolis: $7^{\circ}$ Fazendo Gênero, GT 55, 2006.

ZANINI, Maria Catarina Chitolina. Um olhar antropológico sobre fatos e memórias da imigração italiana. Revista Mana: Rio de Janeiro, 13(2), pp. 521-547, 2007.

ZIDMAN, Claude. Maneiras à mesa. In: Polidez. Porto Alegre: L \& PM, 1993.

ZUCKIN, Sharon. The culture of cities. Malden: Blackwell Publishing, 2002, 6a edição.

ZUCKIN, Sharon. Urban lifestyles: diversity and standardization in spaces of consumption. Urban Studies, 35, no. 5-6, pp. 825-840, May, 1998. 
ZUCKIN, Sharon \& MAGUIRE, Jennifer Smith. Consumers and Consumption. Annual Review Sociological, 30, pp. 173-197, 2004. 

ANEXOS 

APÊNDICE 1

QUADROS DE ENTREVISTADOS

DEPOIMENTOS AVULSOS

\begin{tabular}{|c|c|c|c|c|c|c|}
\hline Nome & $\begin{array}{c}\text { Origem } \\
\text { declarada }\end{array}$ & Atividade & Bairro & Origem & Data & $\begin{array}{c}\text { Idade } \\
\text { no dia } \\
\text { entrevista }\end{array}$ \\
\hline $\begin{array}{l}\text { Fabrizio } \\
\text { Fasano }\end{array}$ & $\begin{array}{c}\text { Milão (norte da } \\
\text { Itália) }\end{array}$ & $\begin{array}{c}\text { Proprietário de } \\
\text { restaurantes e } \\
\text { hotel }\end{array}$ & $\begin{array}{c}\text { Jardins } \\
\text { (começou no } \\
\text { Centro) }\end{array}$ & $\begin{array}{c}\text { Descendente } \\
\text { de italianos } \\
\text { vindos no } \\
\text { começo } \\
\text { século xx }\end{array}$ & $\begin{array}{c}22 \text { de março } \\
2005\end{array}$ & 73 anos \\
\hline Wally & $\begin{array}{l}\text { Brasileira, Mãe } \\
\text { veio de Roma, } \\
\text { pai de Faenza }\end{array}$ & $\begin{array}{l}\text { Dona-de-casa } \\
\text { Envolvida } \\
\text { com atividades } \\
\text { do Circolo } \\
\text { Italiano }\end{array}$ & & $\begin{array}{c}\text { Descendente } \\
\text { de italianos } \\
\text { vindos no } \\
\text { começo } \\
\text { século xx }\end{array}$ & $\begin{array}{c}11 \text { de janeiro } \\
2006\end{array}$ & 73 anos \\
\hline $\begin{array}{l}\text { Ana Maria } \\
\text { Carrer }\end{array}$ & $\begin{array}{l}\text { Nasceu em } \\
\text { Roma, mãe do } \\
\text { Veneto, pai do } \\
\text { "sul da Itália" }\end{array}$ & $\begin{array}{l}\text { Dona-de-casa } \\
\text { Envolvida } \\
\text { com atividades } \\
\text { do Circolo } \\
\text { Italiano }\end{array}$ & & $\begin{array}{c}\text { Chegou em } \\
1948\end{array}$ & $\begin{array}{c}11 \text { de janeiro } \\
2006\end{array}$ & 81 anos \\
\hline João Donato & $\begin{array}{l}\text { Sul da Itália, } \\
\text { cidade próxima } \\
\text { a Nápoles }\end{array}$ & $\begin{array}{c}\text { Dono da } \\
\text { Pizzaria } \\
\text { Castelões }\end{array}$ & Brás & $\begin{array}{c}\text { Descendente } \\
\text { de italianos } \\
\text { vindos no } \\
\text { começo } \\
\text { século XX }\end{array}$ & $\begin{array}{c}18 \text { de janeiro } \\
2006\end{array}$ & 70 anos \\
\hline Ângelo Luisi & $\begin{array}{l}\text { Casalbuono, } \\
\text { província de } \\
\text { Salerno (sul da } \\
\text { Itália) }\end{array}$ & $\begin{array}{c}\text { Proprietário } \\
\text { da Cantina } \\
\text { Capuano }\end{array}$ & Bixiga & $\begin{array}{c}\text { Chegou ao } \\
\text { Brasil em } \\
1949\end{array}$ & $\begin{array}{c}18 \text { de janeiro } \\
2006\end{array}$ & 83 anos \\
\hline $\begin{array}{l}\text { Antonio } \\
\text { Carlos } \\
\text { Marino }\end{array}$ & $\begin{array}{c}\text { Lucca } \\
\text { (Toscana, norte } \\
\text { da Itália) }\end{array}$ & $\begin{array}{c}\text { Proprietário } \\
\text { da Cantina } \\
\text { Carlino }\end{array}$ & Centro & $\begin{array}{c}\text { Descendente } \\
\text { de italianos } \\
\text { vindos no } \\
\text { começo } \\
\text { século xx }\end{array}$ & $\begin{array}{c}13 \text { de outubro } \\
2006\end{array}$ & 57 anos \\
\hline Pedro Porta & $\begin{array}{l}\text { São Marco de } \\
\text { Castellabate, } \\
\text { província de } \\
\text { Salerno (sul da } \\
\text { Itália) }\end{array}$ & $\begin{array}{c}\text { Proprietário } \\
\text { da Confeitaria } \\
\text { DiCunto }\end{array}$ & Mooca & $\begin{array}{c}\text { Genro de } \\
\text { Alfredo } \\
\text { DiCunto, } \\
\text { filho de } \\
\text { italianos que } \\
\text { chegaram no } \\
\text { fim do século } \\
\text { XIX }\end{array}$ & $\begin{array}{c}14 \text { de outubro } \\
2006\end{array}$ & 63 anos \\
\hline
\end{tabular}




\begin{tabular}{|c|c|c|c|c|c|c|}
\hline $\begin{array}{l}\text { Afonso } \\
\text { Roperto }\end{array}$ & $\begin{array}{l}\text { Ele é brasil- } \\
\text { eiro, avô veio } \\
\text { de, Cosenza, } \\
\text { região da } \\
\text { Calábria (sul da } \\
\text { Itália) }\end{array}$ & $\begin{array}{l}\text { Dono da } \\
\text { Cantina } \\
\text { Roperto }\end{array}$ & Bixiga & $\begin{array}{c}\text { Descendente } \\
\text { de italianos } \\
\text { vindos no } \\
\text { começo } \\
\text { século xx }\end{array}$ & $\begin{array}{c}14 \text { de outubro } \\
2006\end{array}$ & 51 anos \\
\hline Paula Lenci & $\begin{array}{l}\text { A família de } \\
\text { Henrique Lenci } \\
\text { veio de Lucca } \\
\text { (região da } \\
\text { Toscana, norte } \\
\text { da Itália) }\end{array}$ & $\begin{array}{l}\text { Dona da } \\
\text { Cantina } \\
\text { Gigetto }\end{array}$ & Centro & $\begin{array}{l}\text { Casada com } \\
\text { bisneto do } \\
\text { fundador } \\
\text { que chegou } \\
\text { começo do } \\
\text { século XX }\end{array}$ & $\begin{array}{c}20 \text { de março } \\
2007\end{array}$ & $\begin{array}{l}\text { Não disse, } \\
\text { entre } 40 \text { e } 45 \\
\text { anos }\end{array}$ \\
\hline $\begin{array}{l}\text { Aurélio } \\
\text { Guzzoni }\end{array}$ & $\begin{array}{c}\text { Bergamo } \\
\text { (região da } \\
\text { Lombardia, } \\
\text { norte da Itália) }\end{array}$ & $\begin{array}{l}\text { Dono do Hotel } \\
\text { e Restaurante } \\
\text { Ca'd'Oro }\end{array}$ & Centro & $\begin{array}{c}\text { Pai chegou } \\
\text { nos anos de } \\
1950\end{array}$ & $\begin{array}{c}20 \text { de março } \\
2007\end{array}$ & 50 anos \\
\hline $\begin{array}{c}\text { Adolfo } \\
\text { Scardovelli }\end{array}$ & $\begin{array}{c}\text { Mãe e ele } \\
\text { brasileiros, a } \\
\text { família veio do } \\
\text { sul da Itália } \\
\text { (Calábria) }\end{array}$ & $\begin{array}{l}\text { Gerente da } \\
\text { Cantina Jardin } \\
\text { di Napoli }\end{array}$ & Santa Cecília & $\begin{array}{c}\text { Descendente } \\
\text { de italianos } \\
\text { vindos no } \\
\text { começo } \\
\text { século xx }\end{array}$ & $\begin{array}{c}20 \text { de março } \\
\text { de } 2007\end{array}$ & 53 anos \\
\hline $\begin{array}{l}\text { Antonio } \\
\text { Carlos } \\
\text { Marino }\end{array}$ & $\begin{array}{l}\text { Lucca (região } \\
\text { da Toscana, } \\
\text { norte da Itália) }\end{array}$ & $\begin{array}{c}\text { Proprietário } \\
\text { da Cantina } \\
\text { Carlino }\end{array}$ & Centro & $\begin{array}{c}\text { Descendente } \\
\text { de italianos } \\
\text { vindos no } \\
\text { começo } \\
\text { século xx }\end{array}$ & $\begin{array}{c}21 \text { de março } \\
2007\left(2^{\mathrm{a}}\right. \\
\text { entrevista })\end{array}$ & \\
\hline $\begin{array}{l}\text { Afonso } \\
\text { Roperto }\end{array}$ & $\begin{array}{l}\text { Ele é brasil- } \\
\text { eiro, avô veio } \\
\text { de, Cosenza, } \\
\text { região da } \\
\text { Calábria (sul da } \\
\text { Itália) }\end{array}$ & $\begin{array}{l}\text { Proprietário da } \\
\text { Cantina } \\
\text { Roperto }\end{array}$ & Bixiga & $\begin{array}{c}\text { Descendente } \\
\text { de italianos } \\
\text { vindos no } \\
\text { começo } \\
\text { século xx }\end{array}$ & $\begin{array}{c}22 \text { de março } \\
2007\left(2^{\mathrm{a}}\right. \\
\text { entrevista })\end{array}$ & \\
\hline $\begin{array}{l}\text { Giovanni } \\
\text { Bruno }\end{array}$ & $\begin{array}{c}\text { San Marco } \\
\text { dei Cavoti } \\
\text { (província de } \\
\text { Benevento, } \\
\text { próxima a } \\
\text { Casalbuono, } \\
\text { região da } \\
\text { Campânia, sul } \\
\text { da Itália }\end{array}$ & $\begin{array}{c}\text { Proprietário da } \\
\text { Cantina } \\
\text { Il sogno } \\
\text { d'anarello }\end{array}$ & Vila Mariana & $\begin{array}{c}\text { Chegou ao } \\
\text { Brasil em } \\
1950\end{array}$ & $\begin{array}{c}22 \text { de março } \\
2007\end{array}$ & 72 anos \\
\hline Paula & $\begin{array}{l}\text { Ela é brasile- } \\
\text { rira, seus avôs } \\
\text { e pai eram da } \\
\text { cidade de Ná- } \\
\text { poles (região } \\
\text { da Campânia, } \\
\text { sul da Itália) }\end{array}$ & $\begin{array}{c}\text { Proprietária } \\
\text { Cantina } \\
\text { Speranza }\end{array}$ & $\begin{array}{l}\text { Bixiga e } \\
\text { Moema }\end{array}$ & $\begin{array}{c}\text { Pai e Avó } \\
\text { chegaram nos } \\
\text { anos } 1950\end{array}$ & $\begin{array}{c}22 \text { de março } \\
2007\end{array}$ & $\begin{array}{c}\text { Não disse, } \\
\text { entre } 35 \text { e } 40 \\
\text { anos }\end{array}$ \\
\hline
\end{tabular}


DEPOIMENTOS COLETADOS NO MUSEU DA IMIGRAÇÃO

\begin{tabular}{|c|c|c|c|c|c|c|c|}
\hline Nome & $\begin{array}{c}\text { Origem } \\
\text { declarada }\end{array}$ & Atividade & Bairro & $\begin{array}{c}\text { Ano } \\
\text { Nascimento }\end{array}$ & Origem & $\begin{array}{c}\text { Data do } \\
\text { Depoimento }\end{array}$ & $\begin{array}{l}\text { Idade } \\
\text { no dia }\end{array}$ \\
\hline $\begin{array}{c}\text { Domenico } \\
\text { Laurenti } \\
\text { (já falecido) }\end{array}$ & $\begin{array}{c}\text { Transmontano } \\
\text { (Itália, não mencio- } \\
\text { nou se é sul ou norte) }\end{array}$ & $\begin{array}{l}\text { Proprietário } \\
\text { Padaria } \\
\text { Basilicata }\end{array}$ & Bixiga & 1904 & $\begin{array}{c}\text { Chegou em } \\
1926 \\
\text { (Transmontano) }\end{array}$ & 06/01/1994 & 90 anos \\
\hline $\begin{array}{c}\text { Alfredo } \\
\text { DiCunto } \\
\text { (já falecido) }\end{array}$ & $\begin{array}{c}\text { Família de Sa- } \\
\text { lerno (região da } \\
\text { Campânia, sul da } \\
\text { Itália) }\end{array}$ & $\begin{array}{c}\text { Proprietário } \\
\text { Confeitaria } \\
\text { DiCunto }\end{array}$ & Mooca & 1922 & $\begin{array}{l}\text { Chegou em } \\
1934 \text { (junto } \\
\text { com seu pai } \\
\text { que já estava } \\
\text { aqui desde } \\
\text { 1878) - Salerno }\end{array}$ & $24 / 05 / 1996$ & 74 anos \\
\hline $\begin{array}{c}\text { Nunziato } \\
\text { Petrizzo }\end{array}$ & $\begin{array}{c}\text { San Giacomo } \\
\text { (província de } \\
\text { Salerno, região da } \\
\text { Campânia, sul da } \\
\text { Itália) }\end{array}$ & $\begin{array}{l}\text { Aposentado, } \\
\text { acompanhou } \\
\text { o desenvolvi- } \\
\text { mento do bairro } \\
\text { da Mooca }\end{array}$ & & 1947 & $\begin{array}{c}\text { Chegou em } \\
1952-\text { San } \\
\text { Giacomo }\end{array}$ & 22/07/1997 & 50 anos \\
\hline $\begin{array}{c}\text { Nicola } \\
\text { Racciopi }\end{array}$ & $\begin{array}{c}\text { San Giacomo } \\
\text { (província de } \\
\text { Salerno, região da } \\
\text { Campânia, sul da } \\
\text { Itália) }\end{array}$ & $\begin{array}{l}\text { Aposentado, } \\
\text { acompanhou } \\
\text { o desenvolvi- } \\
\text { mento do bairro } \\
\text { da Mooca }\end{array}$ & & 1932 & $\begin{array}{c}\text { Chegou em } \\
1952- \\
\text { San Giacomo }\end{array}$ & 17/07/1997 & 65 anos \\
\hline $\begin{array}{l}\text { Mariana Della- } \\
\text { role del Moro } \\
\text { (já falecida) }\end{array}$ & $\begin{array}{l}\text { Brasileira, pais de } \\
\text { Turim (Torino), } \\
\text { região do Pie- } \\
\text { monte, norte da } \\
\text { Itália }\end{array}$ & $\begin{array}{l}\text { Possuía uma } \\
\text { pequena fábrica } \\
\text { de massas } \\
\text { caseiras }\end{array}$ & & 1926 & $\begin{array}{l}\text { O pai chegou } \\
\text { em } 1911 \text { (eram } \\
\text { do Piemonte) }\end{array}$ & 28/08/1997 & 71 anos \\
\hline $\begin{array}{c}\text { Giovanna } \\
\text { Nicoletti } \\
\text { Facchinetti }\end{array}$ & $\begin{array}{c}\text { Ela nasceu na } \\
\text { província de } \\
\text { Salerno (região } \\
\text { da Campânia, sul } \\
\text { da Itália) }\end{array}$ & $\begin{array}{l}\text { Ajudou o pai, } \\
\text { verdureiro }\end{array}$ & & 1925 & $\begin{array}{c}\text { Chegou em } \\
1953 \text { - Salerno }\end{array}$ & $16 / 09 / 1998$ & 73 anos \\
\hline $\begin{array}{c}\text { Annita } \\
\text { Concetta de } \\
\text { Caro Santos }\end{array}$ & Brasileira & $\begin{array}{l}\text { Ajudou a mãe } \\
\text { na fábrica de } \\
\text { massas que } \\
\text { fornecia para } \\
\text { a Cantina } \\
\text { Balila, Brás }\end{array}$ & & 1936 & $\begin{array}{c}\text { Nasceu no } \\
\text { Brasil em } 1936 \\
\text { (não lembra a } \\
\text { data que seus } \\
\text { pais chegaram) }\end{array}$ & 03/11/1998 & 62 anos \\
\hline
\end{tabular}




\begin{tabular}{|c|c|c|c|c|c|c|c|}
\hline $\begin{array}{c}\text { Epihania } \\
\text { Lauria }\end{array}$ & Brasileira & $\begin{array}{l}\text { Chapeleira, } \\
\text { pai era com- } \\
\text { erciante de } \\
\text { vinho }\end{array}$ & & 1921 & $\begin{array}{c}\text { Nasceu em } \\
\text { São Paulo, } \\
\text { pais imi- } \\
\text { grantes acre- } \\
\text { dita-se da } \\
\text { Calábria }\end{array}$ & 06/10/1998 & 77 anos \\
\hline $\begin{array}{c}\text { Bruno } \\
\text { Giovanetti }\end{array}$ & $\begin{array}{l}\text { Brasileiro, } \\
\text { família veio } \\
\text { de Lucca, } \\
\text { região da Tos- } \\
\text { cana, } \\
\text { norte da Itália }\end{array}$ & Fotógrafo & & 1947 & $\begin{array}{l}\text { Nasceu em } \\
\text { São Paulo }\end{array}$ & $01 / 03 / 2001$ & 54 anos \\
\hline $\begin{array}{c}\text { Francisco } \\
\text { Firmo } \\
\text { Pedro } \\
\text { Savoldi }\end{array}$ & Brasileiro & & & 1930 & $\begin{array}{c}\text { Nasceu em } \\
\text { São Paulo } \\
\text { - pai veio } \\
\text { em } 1921 \text { e } \\
\text { mãe veio em } \\
1880 \\
\end{array}$ & $26 / 03 / 1999$ & 69 anos \\
\hline $\begin{array}{c}\text { Grandi Pie- } \\
\text { ro Luisi }\end{array}$ & $\begin{array}{l}\text { Cidade de } \\
\text { Lucca, região } \\
\text { da Toscana, } \\
\text { norte da Itália }\end{array}$ & $\begin{array}{l}\text { Dono da } \\
\text { Cantina do } \\
\text { Piero }\end{array}$ & Jardins & 1934 & $\begin{array}{c}\text { Chegou } \\
\text { em } 1954- \\
\text { nasceu em } \\
\text { Lucca } \\
\text { (Toscana) }\end{array}$ & $24 / 10 / 2001$ & 67 anos \\
\hline
\end{tabular}




\begin{tabular}{|c|c|c|c|c|c|c|}
\hline $\begin{array}{c}\text { Giulia } \\
\text { Goggini } \\
\text { Piastrelli }\end{array}$ & $\begin{array}{c}\text { Brasileira, } \\
\text { seus pais vie- } \\
\text { ram da região } \\
\text { da } \\
\text { Toscana } \\
\text { (norte da Itá- } \\
\text { lia) }\end{array}$ & $\begin{array}{l}\text { Pais foram } \\
\text { proprietários } \\
\text { de Sorvet- } \\
\text { eria }\end{array}$ & 1927 & $\begin{array}{l}\text { Nasceu em } \\
\text { São Paulo, } \\
\text { pais vieram } \\
\text { em 1926, } \\
\text { foram donos } \\
\text { de sorveteria, } \\
\text { eram Tos- } \\
\text { canos e vol- } \\
\text { taram para } \\
\text { a Itália em } \\
\text { 1932. Giulia } \\
\text { retornou em } \\
1950\end{array}$ & $10 / 10 / 2001$ & 74 anos \\
\hline $\begin{array}{c}\text { Bruno } \\
\text { Caramelli }\end{array}$ & Brasileiro & $\begin{array}{l}\text { Médico, } \\
\text { participou } \\
\text { ativamente } \\
\text { do Circolo } \\
\text { Italiano fun- } \\
\text { dado pelo } \\
\text { seu avô }\end{array}$ & 1960 & $\begin{array}{c}\text { Pai chegou } \\
\text { ao Brasil em } \\
1952\end{array}$ & $24 / 10 / 2001$ & 51 anos \\
\hline
\end{tabular}





\section{Mapa 1 - Distribuição Geopolítica da Itália e suas regiões}

1- ABRUZZO

2- BASILICATA

3- CALABRIA

4- CAMPANIA

5- EMILIA-ROMAGNA

6- FRIULI-VENEZIA GIULIA

7- LAZIO

8- LIGURIA

9- LOMBARDIA

10- MARCHE

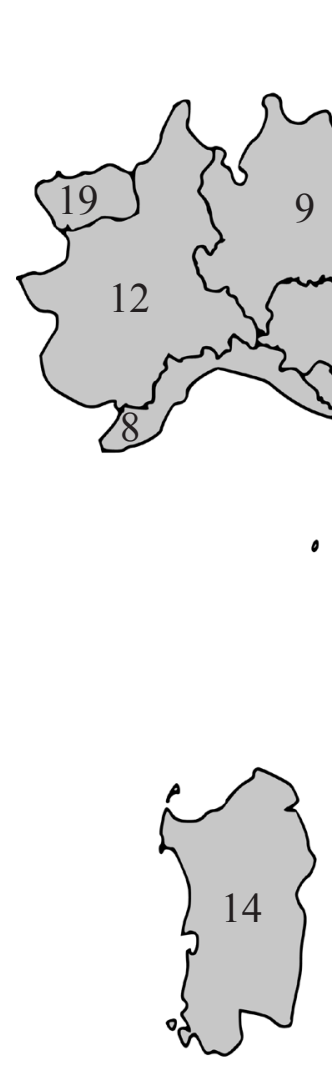

11- MOLISE

12- PIEMONTE

13- PUGLIA

14- SARDEGNA

15- SICILIA

16- TOSCANA

17- TRENTINO-ALTO ADIGE

18- UMBRIA

19- VALLE D'AOSTA

20- VENETO

Fonte: BERALDO, Lea Silveira. 07/2007. Imigrantes Italianos: Itália - divisão geopolítica. www.imigrantesitalianos. com.br/Provincias_Italianas.html. 1/07/2009. 
Cada Região, de seu turno, está dividida nas seguintes Províncias (são 108 ao todo):

\begin{tabular}{|c|c|c|c|}
\hline REGIÕES & PROVÍNCIAS & $\begin{array}{c}\text { NÚMERO } \\
\text { DE } \\
\text { “COMUNI” } \\
\text { EM CADA PROVÍNCIA }\end{array}$ & $\begin{array}{c}\text { NÚMERO TOTAL } \\
\text { DE CIDADES } \\
\text { (“COMUNI”) }\end{array}$ \\
\hline 1. ABRUZZO & $\begin{array}{l}1 \text { - Chieti - } \mathrm{CH} \\
2 \text { - L'Aquila - AQ } \\
3 \text { - Pescara - PE } \\
4 \text { - Teramo - TE }\end{array}$ & $\begin{array}{c}1-104 \\
2-108 \\
3-46 \\
4-47\end{array}$ & 305 \\
\hline 2. BASILICATA & $\begin{array}{l}1 \text { - Matera - MT } \\
2 \text { - Potenza - PZ }\end{array}$ & $\begin{array}{c}1-31 \\
2-100\end{array}$ & 131 \\
\hline 3. CALABRIA & $\begin{array}{l}1 \text { - Catanzaro - CZ } \\
2 \text { - Cosenza - CS } \\
3 \text { - Crotone - KR } \\
4 \text { - Reggio Calabria - RC } \\
5 \text { - Vibo Valentia - VV }\end{array}$ & $\begin{array}{l}1-80 \\
2-155 \\
3-27 \\
4-97 \\
5-50\end{array}$ & 409 \\
\hline 4. CAMPANIA & $\begin{array}{l}1 \text { - Avellino - AV } \\
2 \text { - Benevento - BN } \\
3 \text { - Caserta - CE } \\
4 \text { - Napoli - NA } \\
5 \text { - Salerno - SA }\end{array}$ & $\begin{array}{l}1-119 \\
2-78 \\
3-104 \\
4-92 \\
5-158\end{array}$ & 551 \\
\hline 5. EMILIA-ROMAGNA & $\begin{array}{l}1 \text { - Bologna - BO } \\
2 \text { - Ferrara - FE } \\
3 \text { - Forlì-Cesena - FO } \\
4 \text { - Modena - MO } \\
5 \text { - Parma - PR } \\
6 \text { - Piacenza - PC } \\
7 \text { - Ravenna - RA } \\
8 \text { - Reggio Emilia - RE } \\
9 \text { - Rimini - RN }\end{array}$ & $\begin{array}{l}1-60 \\
2-26 \\
3-30 \\
4-47 \\
5-47 \\
6-48 \\
7-18 \\
8-45 \\
9-20\end{array}$ & 341 \\
\hline
\end{tabular}




\begin{tabular}{|c|c|c|c|}
\hline $\begin{array}{l}\text { 6. FRIULI-VENEZIA } \\
\text { GIULIA }\end{array}$ & $\begin{array}{l}1 \text { - Gorizia - GO } \\
2 \text { - Pordenone - PN } \\
3 \text { - Trieste - TS } \\
4 \text { - Udine - UD }\end{array}$ & $\begin{array}{c}1-25 \\
2-51 \\
3-6 \\
4-137\end{array}$ & 219 \\
\hline 7. LAZIO & $\begin{array}{l}1 \text { - Frosinone - FR } \\
2 \text { - Latina - LT } \\
3 \text { - Rieti - RI } \\
4 \text { - Roma - ROMA } \\
5 \text { - Viterbo - VT }\end{array}$ & $\begin{array}{l}1-91 \\
2-33 \\
3-73 \\
4-121 \\
5-60\end{array}$ & 378 \\
\hline 8. LIGURIA & $\begin{array}{l}1 \text { - Genova - GE } \\
2 \text { - Imperia - IM } \\
3 \text { - La Spezia - SP } \\
4 \text { - Savona - SV }\end{array}$ & $\begin{array}{l}1-67 \\
2-67 \\
3-32 \\
4-69\end{array}$ & 235 \\
\hline 9. LOMBARDIA & $\begin{array}{l}1 \text { - Bergamo - BG } \\
2 \text { - Brescia - BS } \\
3 \text { - Como - CO } \\
4 \text { - Cremona - CR } \\
5 \text { - Lecco - LC } \\
6 \text { - Lodi - LO } \\
7 \text { - Mantova - MN } \\
8 \text { - Milano - MI } \\
9 \text { - Pavia - PV } \\
10 \text { - Sondrio - SO } \\
11 \text { - Varese - VA }\end{array}$ & $\begin{array}{c}1-244 \\
2-206 \\
3-163 \\
4-115 \\
5-90 \\
6-61 \\
7-70 \\
8-188 \\
9-190 \\
10-78 \\
11-141\end{array}$ & 1.545 \\
\hline 10. MARCHE & $\begin{array}{l}1 \text { - Ancona - AN } \\
2 \text { - Ascoli Piceno - AP } \\
3 \text { - Macerata - MC } \\
4 \text { - Pesaro Urbino - PS }\end{array}$ & $\begin{array}{l}1-49 \\
2-73 \\
3-57 \\
4-67\end{array}$ & 246 \\
\hline 11. MOLISE & $\begin{array}{l}1 \text { - Campobasso - CB } \\
2 \text { - Isernia - IS }\end{array}$ & $\begin{array}{l}1-84 \\
2-52\end{array}$ & 136 \\
\hline
\end{tabular}




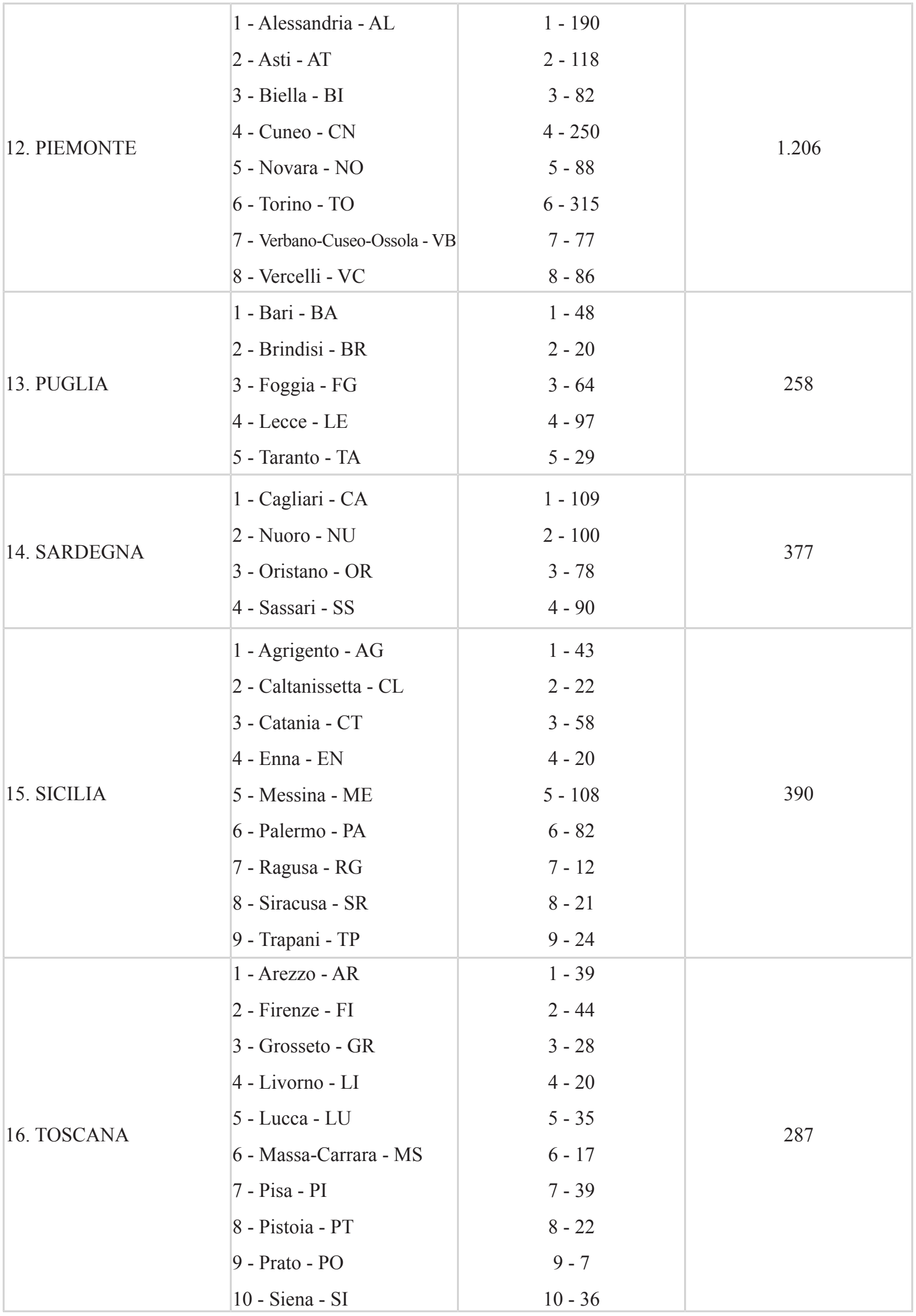




\begin{tabular}{|c|c|c|c|}
\hline $\begin{array}{l}\text { 17. TRENTINO-ALTO } \\
\text { ADIGE }\end{array}$ & $\begin{array}{l}1 \text { - Bolzano - BZ } \\
2 \text { - Trento - TN }\end{array}$ & $\begin{array}{l}1-116 \\
2-223\end{array}$ & 339 \\
\hline 18. UMBRIA & $\begin{array}{l}1 \text { - Perugia - PG } \\
2 \text { - Terni - TR }\end{array}$ & $\begin{array}{l}1-59 \\
2-33\end{array}$ & 92 \\
\hline 19. VALE D'AOSTA & 1 - Aosta - AO & $1-74$ & 74 \\
\hline 20. VENETO & $\begin{array}{l}\text { 1 - Belluno - BL } \\
\text { 2- Padova - PD } \\
\text { 3- Rovigo - RO } \\
\text { 4- Treviso - TV } \\
\text { 5- Venezia - VE } \\
\text { 6- Verona - VR } \\
\text { 7- Vicenza - VI }\end{array}$ & $\begin{array}{c}1-69 \\
2-104 \\
3-50 \\
4-95 \\
5-44 \\
6-98 \\
7-121\end{array}$ & 581 \\
\hline
\end{tabular}

Fonte: BERALDO, Lea Silveira. 07/2007. Imigrantes Italianos: Itália - divisão geopolítica. www.imigrantesitalianos. com.br/Provincias_Italianas.html. 1/07/2009. 



\section{APÊNDICE 3}

\section{Mapa da cidade de São Paulo e seus bairros}

Zona Central
01 - Barra Funda
02 - Bela Vista
03 - Bom Retiro
04 - Brás
05 - Consolação
06 - Liberdade
07 - Pari
08 - República
09 - Santa Cecília
10 - Sé
Zona Norte
11 - Casa Verde
12 - Jaçanã
13 - Mandaqui
14 - Santana
15 - Tremembé
16 - Tucuruvi
17 - Vila Guilherme
18 - Vila Maria
19 - Vila Medeiros
Zona Oeste
78 - Alto de Pinheiros
79 - Anhanguera
80 - Brasilândia
81 - Butantã
82 - Cachoeirinha
83 - Freguesia do Ó
84 - Jaguará
85 - Jaguaré
86 - Jaraguá
87 - Lapa
88 - Limão
89 - Perdizes
90 - Perus
91 - Pinheiros
92 - Pirituba
93 - Raposo Tavares
94 - Rio Pequeno
95 - Vila Leopoldina

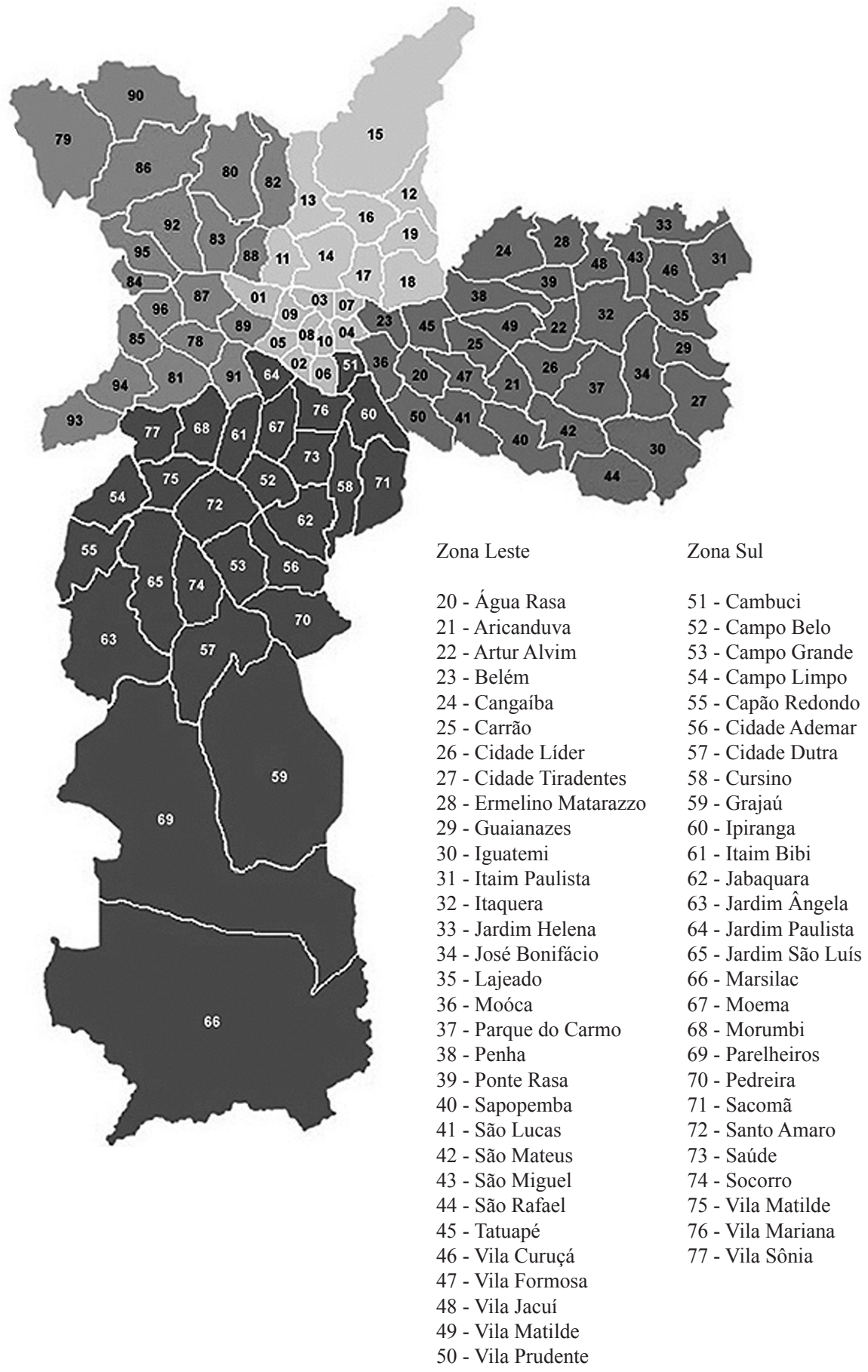

Fonte: AKIRARW. 01/2006. Sonorica. http://sonorica.blogspot.com/2009_01_01_archive.html. 25/01/2009. 



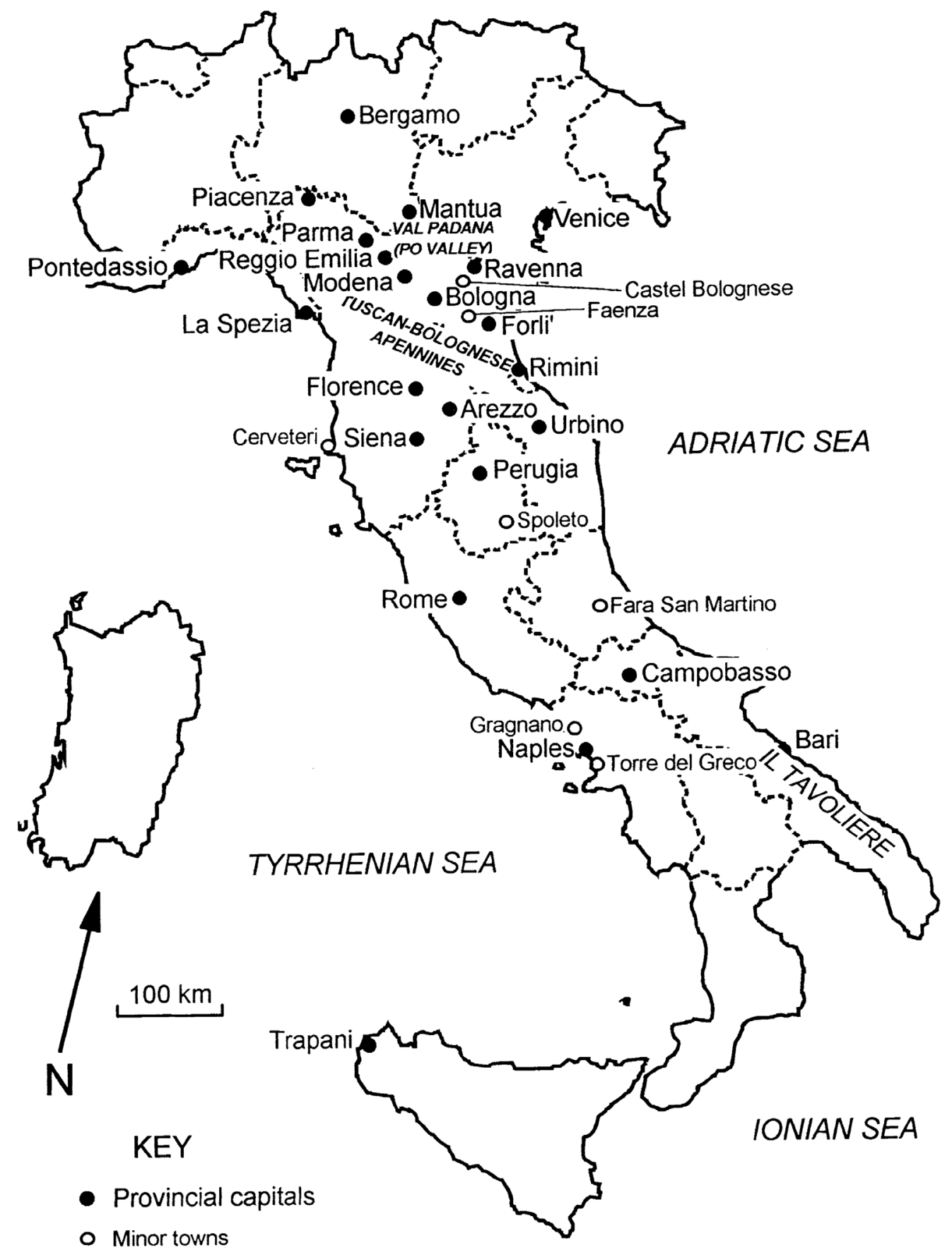

Fonte: ALEXANDER, Davi. The Geography of Italian Pasta. In: Professional Geographer, número 52 (3), 2000 , p. 554. 


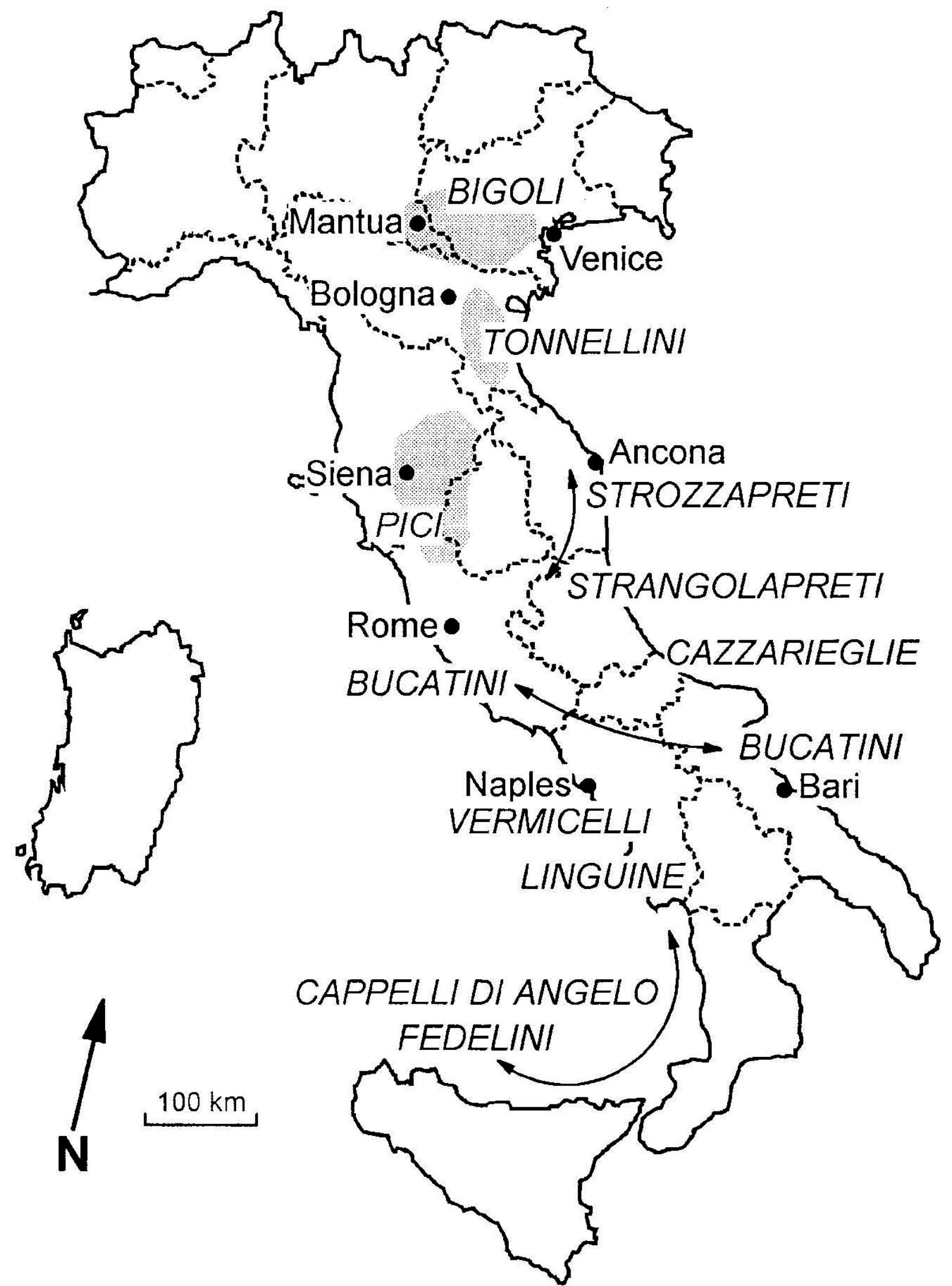

Fonte: ALEXANDER, Davi. The Geography of Italian Pasta. In: Professional Geographer, número 52 (3), 2000, p. 558 . 


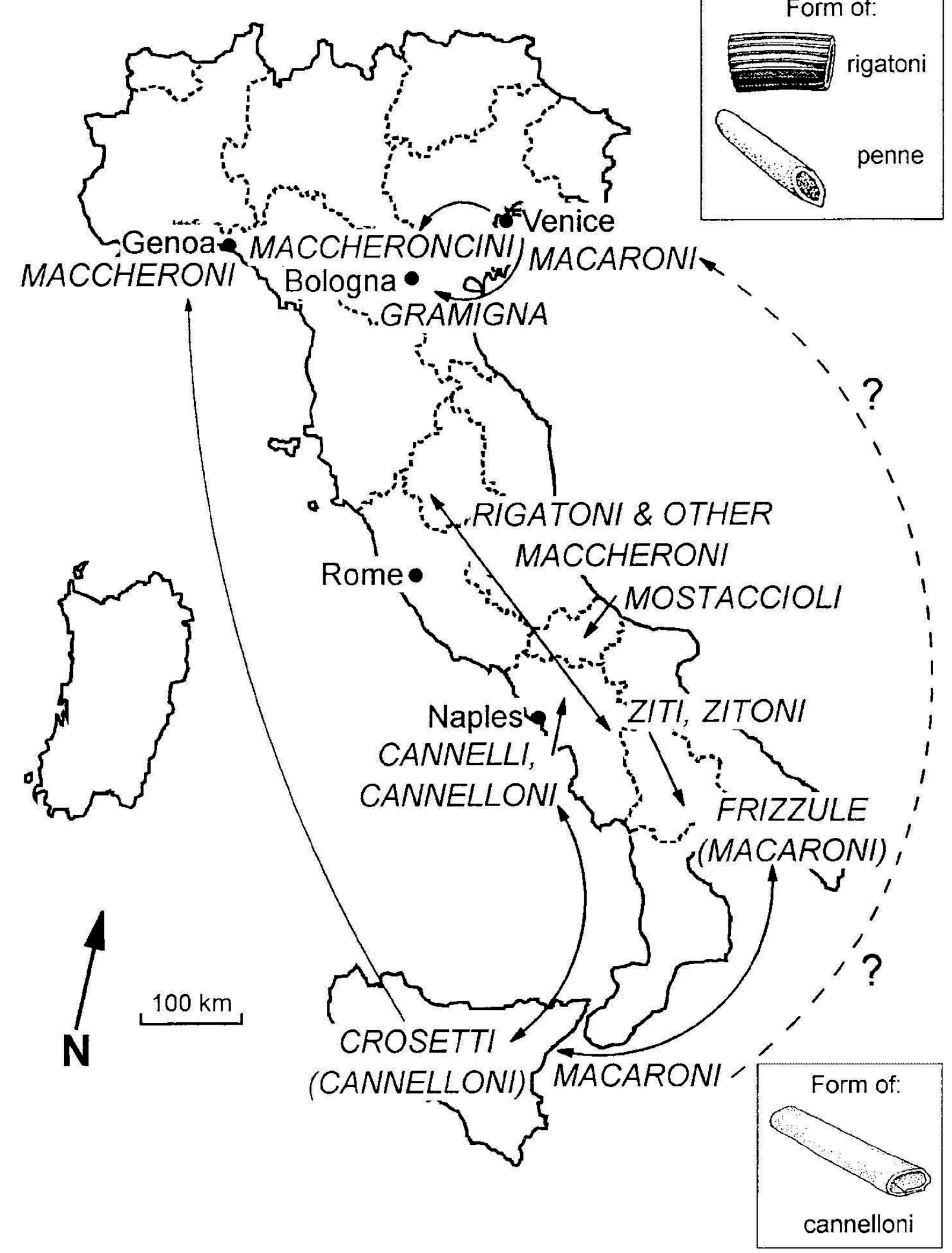

Fonte: ALEXANDER, Davi. The Geography of Italian Pasta. In: Professional Geographer, número 52 (3), 2000 , p. 558. 


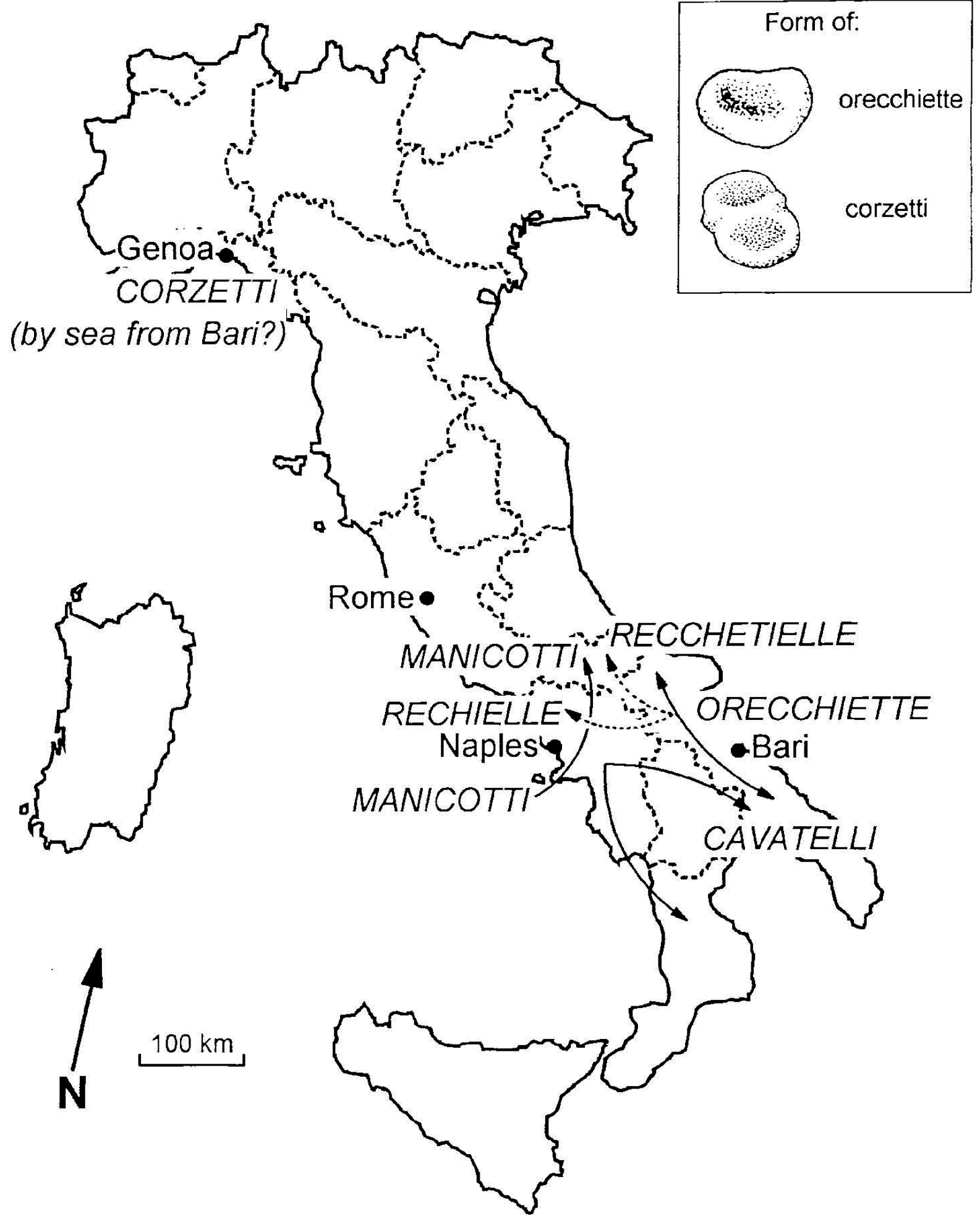

Fonte: ALEXANDER, Davi. The Geography of Italian Pasta. In: Professional Geographer, número 52 (3), 2000, p. 558. 


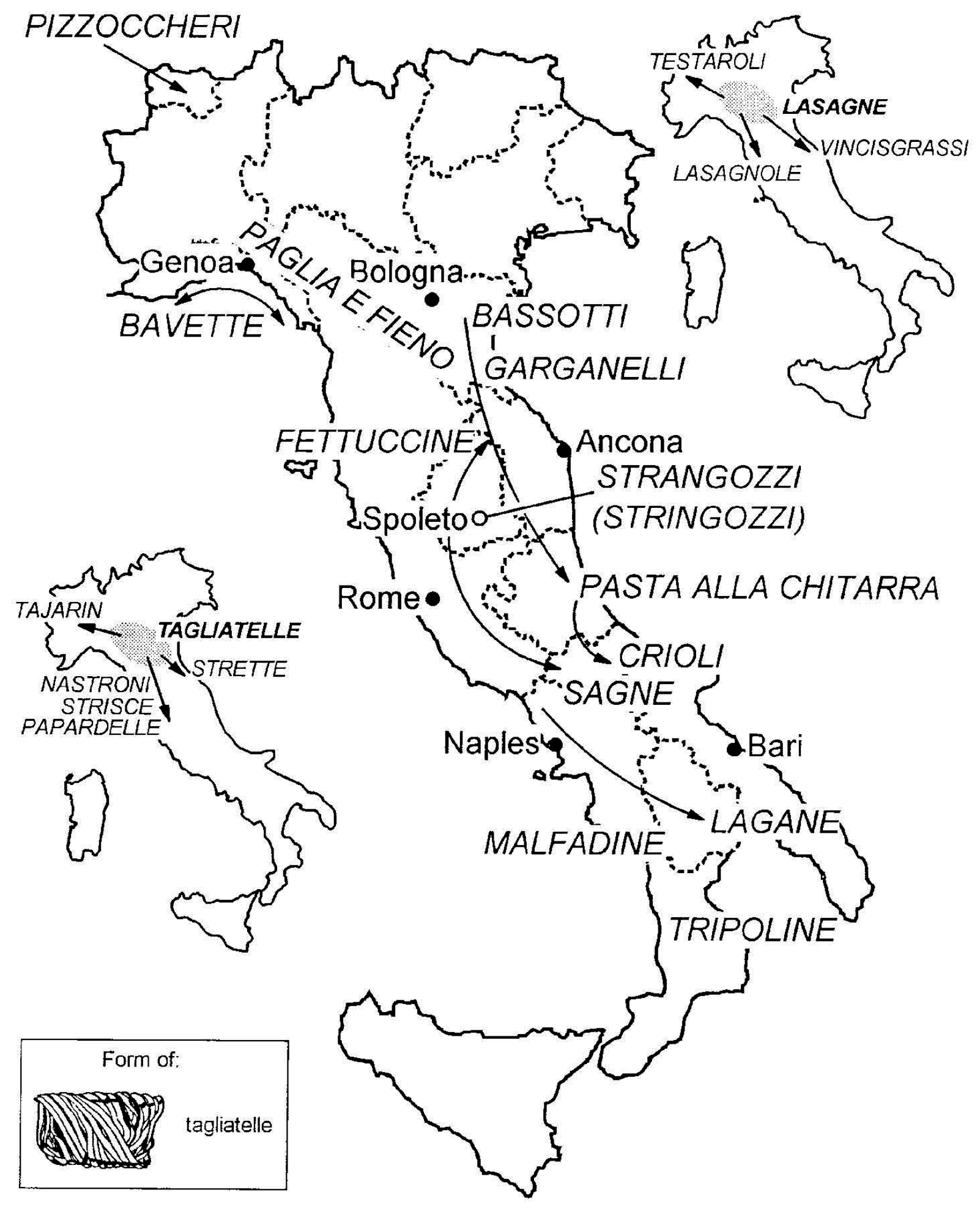

Fonte: ALEXANDER, Davi. The Geography of Italian Pasta. In: Professional Geographer, número 52 (3), 2000 , p. 558. 


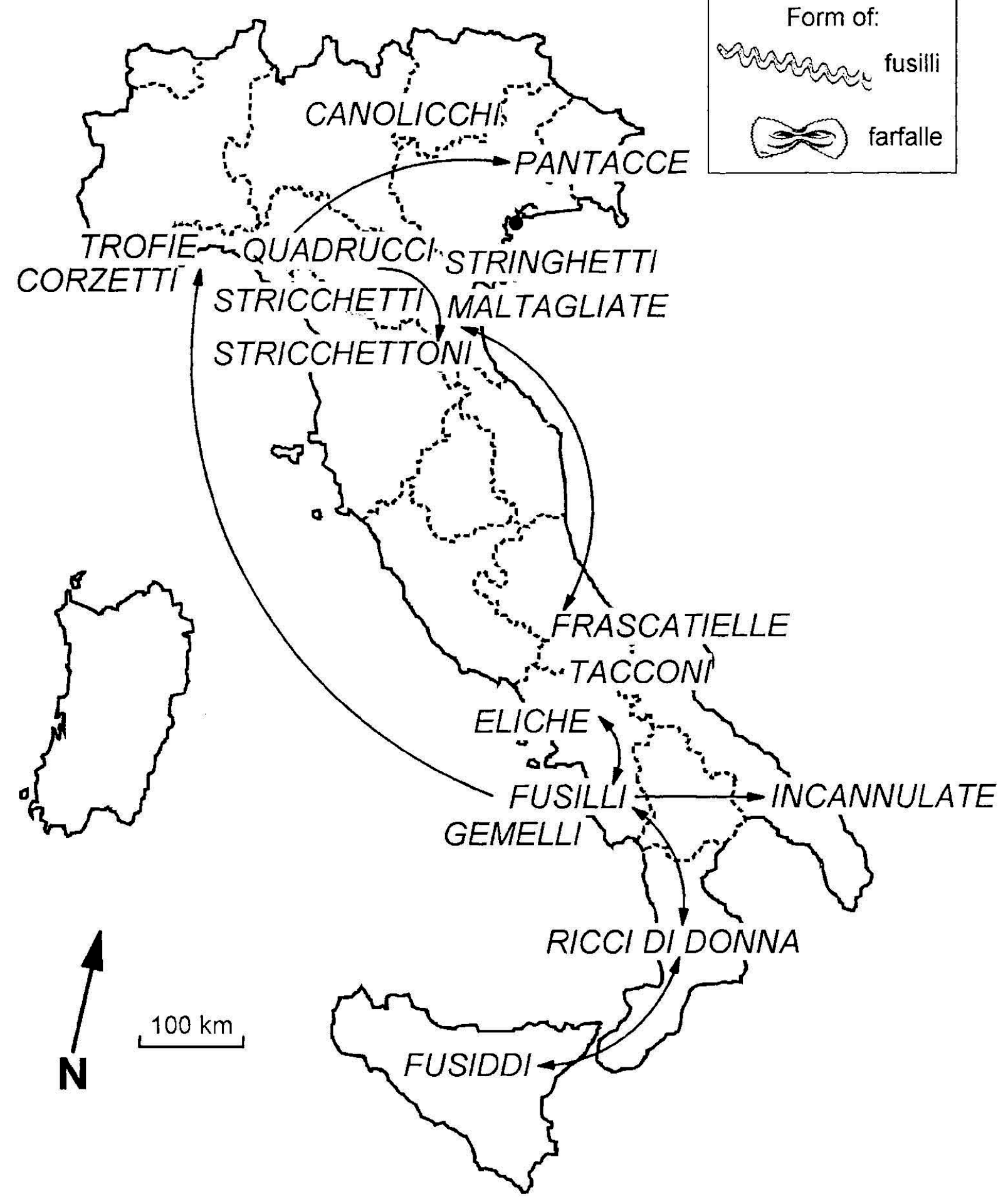

Fonte: ALEXANDER, Davi. The Geography of Italian Pasta. In: Professional Geographer, número 52 (3), 2000, p. 559. 


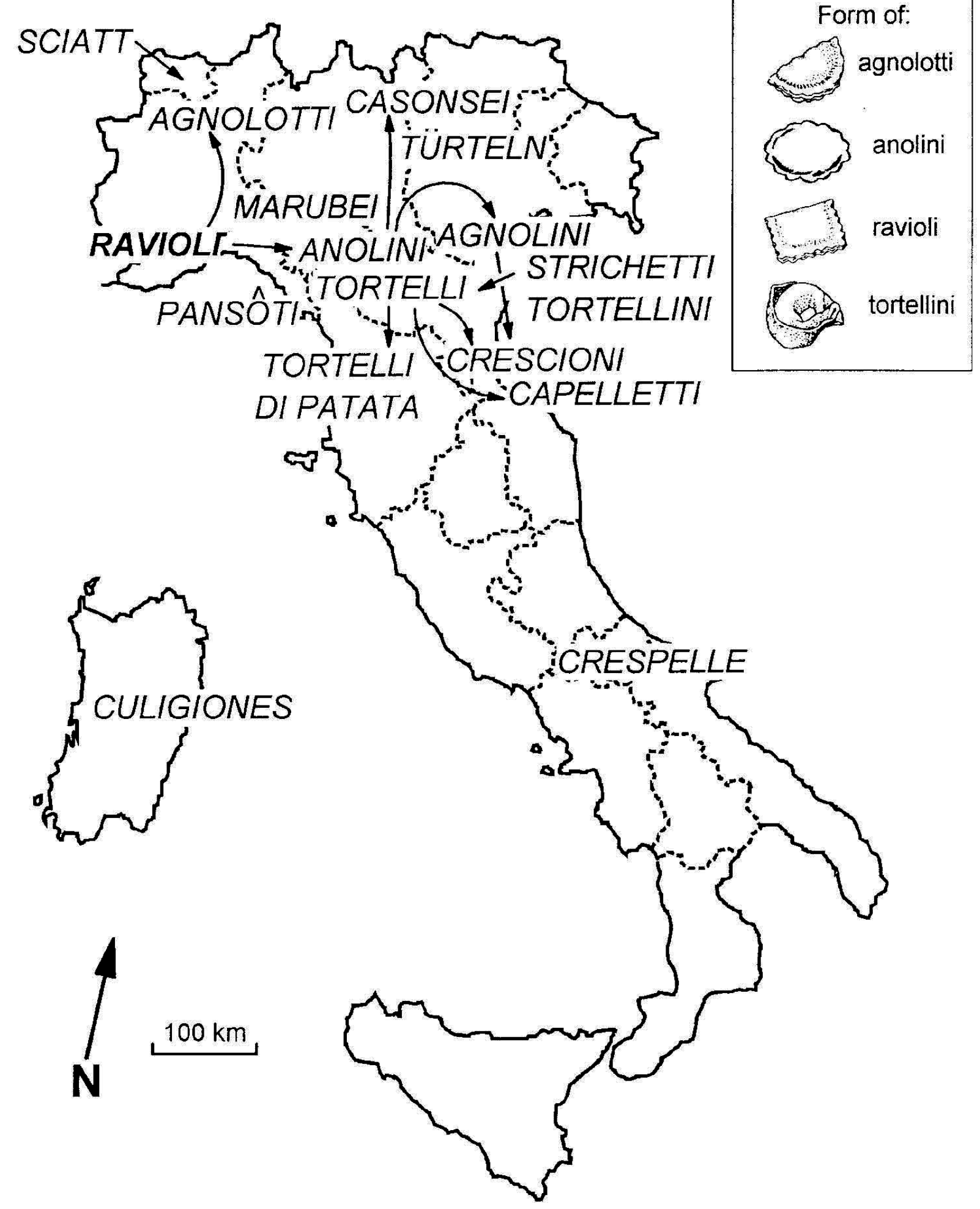

Fonte: ALEXANDER, Davi. The Geography of Italian Pasta. In: Professional Geographer, número 52 (3), 2000 , p. 559. 


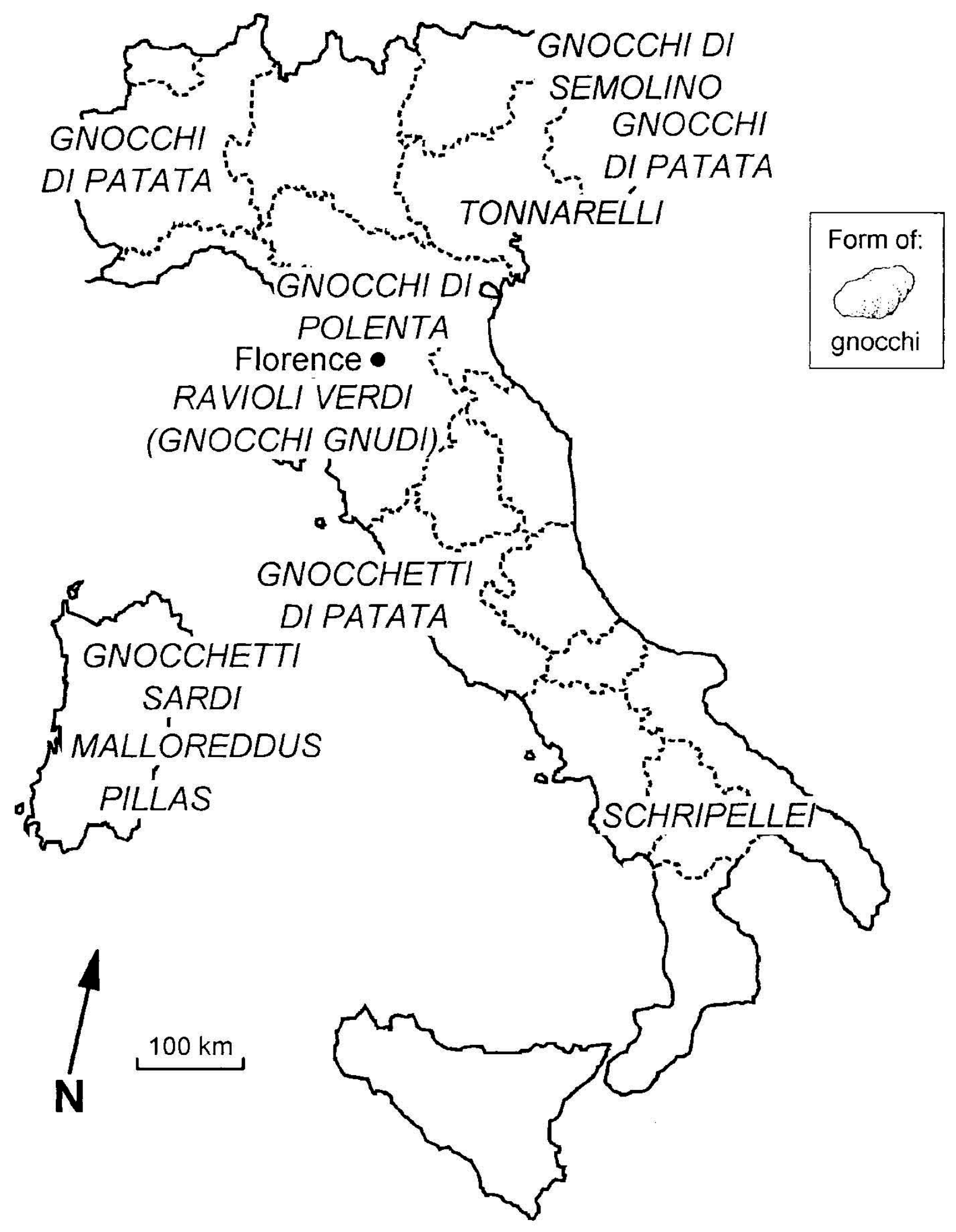

Fonte: ALEXANDER, Davi. The Geography of Italian Pasta. In: Professional Geographer, número 52 (3), 2000, p. 559. 


\section{APÊNDICE 5}

\section{Roteiro Básico - Entrevistas Doutorado ${ }^{283}$}

1) Qual foi a trajetória de sua família? E a sua?

2) Como surgiu o restaurante?

3) Qual é sua relação com o bairro? A região?

4) Do que você se lembra dos primeiros tempos em que começou a trabalhar no restaurante?

5) Quais eram as diferenças sentidas entre hoje e naquela época?

6) O que você nota com relação à comida? À clientela? Com relação ao seu trabalho e de seu pai ou quem administrava antes de você?

7) Como é a relação com sua família?

8) Qual é o papel da mulher na cozinha?

9) E de modo geral?

10) O que é para você o trabalho?

11) Qual é o sentido de prosperar?

12) O que é cozinha italiana?

13) Como você vê essa cozinha antes e agora?

14) O que você acha da ideia de São Paulo como capital gastronômica?

15) Você acha que isso tem algum benefício para seu restaurante? Como o bairro se beneficiou disso?

16) Na sua opinião, você acha que a culinária italiana teve alguma influência nessa noção de capital gastronômica?

17) O que você acha dos restaurantes hoje em São Paulo? Você acha que nosso gosto pode ser dito cosmopolita?

18) Como você vê a culinária italiana atualmente?

19) Atualmente, você vê a relação da gastronomia e turismo? Há algum benefício para seu restaurante?

20) Quais as características que permitiram que São Paulo se transformasse em uma capital gastronômica, em sua opinião?

21) Você acha que os guias de restaurantes tiveram algum impacto na divulgação de seu restaurante? De ampliar o hábito de comer fora?

22) Sobre nostalgia, tem saudade de algo, os pais ou ele comentam sobre coisas do passado?

23) Sobre a pluralidade cultural, o que pensa, como a vê, no que ajudou para a construção da cidade?

283 Na realidade, este roteiro contém as perguntas que minimamente eu gostaria que fossem respondidas, mas, em diversas ocasiões, surgiram outras questões em função das colocações feitas pelos entrevistados. 